UNIVERSIDADE DE SÃO PAULO

FACULDADE DE ECONOMIA, ADMINISTRAÇÃO E CONTABILIDADE DEPARTAMENTO DE ADMINISTRAÇÃO PROGAMA DE PÓS-GRADUAÇÃo EM ADMINISTRAÇÃo

ATRIBUTOS DE PARCERIAS DE SUCESSO EM CADEIAS DE SUPRIMENTOS:

UM ESTUDO DE CASO NA RELAÇÃO FABRICANTE-FORNECEDOR NA INDÚSTRIA AERONÁUTICA

Carlos Eduardo Bastos

Orientador: Prof. Dr. Marilson Alves Gonçalves

SÃO PAULO 
Prof $^{a}$. Dr ${ }^{a}$. Suely Vilela

Reitor da Universidade de São Paulo

Prof. Dr. Carlos Roberto Azzoni

Diretor da Faculdade de Economia, Administração e Contabilidade

Prof. Dr. Isak Kruglianskas

Chefe do Departamento de Administração

Prof. Dr. Lindolfo Galvão de Albuquerque

Coordenador do Programa de Pós-Graduação em Administração 
CARLOS EDUARDO BASTOS

\section{ATRIBUTOS DE PARCERIAS DE SUCESSO EM CADEIAS DE SUPRIMENTOS: UM ESTUDO DE CASO NA RELAÇÃO FABRICANTE-FORNECEDOR NA INDÚSTRIA AERONÁUTICA}

Dissertação apresentada ao Departamento de Administração da Faculdade de Economia, Administração e Contabilidade da Universidade de São Paulo como requisito para a obtenção do título de Mestre em Administração.

Orientador: Prof. Dr. Marilson Alves Gonçalves

\section{SÃo PAULO}




\section{FICHA CATALOGRÁFICA}

Elaborada pela Seção de Processamento Técnico do SBD/FEA/USP

Bastos, Carlos Eduardo

Atributos de parcerias de sucesso em cadeias de suprimentos: um estudo de caso na relação fabricante-fornecedor na indústria aeronáutica / Carlos Eduardo Bastos. -- São Paulo, 2006.

$180 \mathrm{p}$.

Dissertação (Mestrado) - Universidade de São Paulo, 2006

Bibliografia.

1. Gestão do fornecimento 2. Rede de suprimentos - Gerenciamento 3. Administração de compras 4. Empresas I. Universidade de São Paulo Faculdade de Economia, Administração e Contabilidade II. Título.

$$
\text { CDD }-658.7
$$


À minha querida esposa e filhos, com amor, pela paciência e compreensão. 


\section{AGRADECIMETOS}

Ao meu orientador Prof. Dr. Marilson Alves Gonçalves, pelas idéias desafiadoras, pelo incentivo, pela compreensão e apoio.

Aos Mestres da casa com os quais tive a oportunidade de ampliar meus conhecimentos, aos funcionários e a FEA USP, pelo apoio institucional e pelas facilidades oferecidas.

À Prof ${ }^{a}$ Dr $^{a}$ Bernadete de Lourdes Marinho pelas sugestões para a melhoria da metodologia e do instrumento de pesquisa utilizado neste trabalho.

Ao amigo Henrique Guaragna pela troca de idéias, discussões conceituais, críticas, sugestões e apoio na revisão do texto.

Aos companheiros de vida acadêmica - Natércia, Gustavo, Mancia, César e Aldo, pela contribuição prestada.

À Embraer pelas facilidades oferecidas para que eu pudesse cumprir este desafio a contento.

Agradeço também, de forma especial, aos companheiros da Embraer que se dispuseram a participar e contribuir com esta pesquisa. 
“... nós encontramos ilhas de poder consciente neste oceano de cooperação inconsciente..."

D. H. Robertson 


\section{RESUMO}

No contexto atual do ambiente empresarial, a gestão da cadeia de suprimentos surge como um veículo através do qual as empresas podem obter vantagem competitiva. As empresas passaram a ser instadas a alterar o modelo tradicional de relacionamento distante e de curto prazo - mercado puro, com seus fornecedores, por uma relação colaborativa de longo prazo parceria. A literatura relevante sobre parceria destaca uma série de atributos e características que devem estar presentes neste tipo de relacionamento, para que as empresas possam atingir os resultados a que se propuseram. Nesta pesquisa, desenvolve-se uma análise da literatura relevante em gestão de cadeia de suprimentos e gestão de relacionamentos, e apresenta-se um modelo conceitual, desenvolvido por Mohr e Spekman e revisitado pelo autor, que expõe os fatores associados a parcerias de sucesso. Um estudo de caso foi realizado, durante o ano de 2006, mostrando a evolução do modelo de relacionamento entre fabricante e fornecedor, em uma indústria aeronáutica brasileira, buscando verificar a presença ou não das características do modelo apresentado. $\mathrm{O}$ resultado do estudo gera a percepção de que, embora tenha havido uma evolução no relacionamento fabricante-fornecedor em direção ao modelo colaborativo, ainda existe um bom caminho a ser trilhado pela empresa para atingir a relação de parceria preconizada pelo modelo referencial utilizado neste trabalho.

Palavras-chave: gestão da cadeia de suprimentos, parceria, relacionamento fabricantefornecedor 


\begin{abstract}
In the current context of enterprise environmental, supply chain management appear as a vehicle through which a company can get competitive advantage. Companies started to be pushed to change the traditional far away and short term relationship model - arm's length with their suppliers for a long term collaborative relation - partnership. The relevant literature about partnership points out a series of attributes and characteristics that should be present in this kind of relationship in order to allow companies to attain proposed results. This research develops an analysis of relevant literature concerning supply chain management and relationship management, and provides a conceptual model, developed by Mohr and Spekman and revisited by this author, that shows the factors associated with successful partnership. A case study is dropped, during 2006, showing the evolution of such buyer-supplier relationship model, in a Brazilian aerospace industry, searching to verify the presence or not of those attributes presented in the conceptual model. Results from the study generates a perception that, although have been noticed an evolution on buyer-supplier relationship toward the collaborative model, there is a long way ahead to meet the partnership referenced at the conceptual model presented in this study.
\end{abstract}

Key words: supply chain management, partnership, buyer-supplier relationship 


\section{SUMÁRIO}

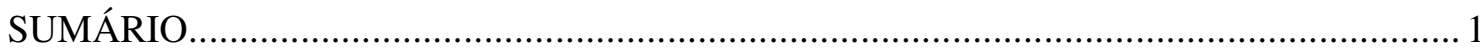

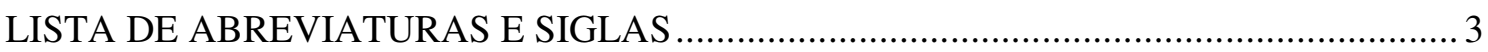

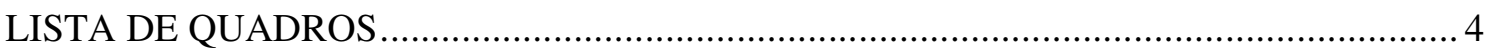

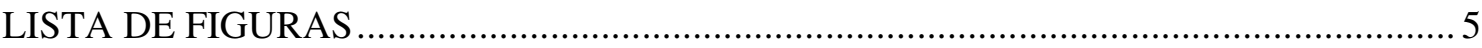

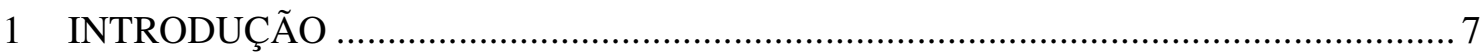

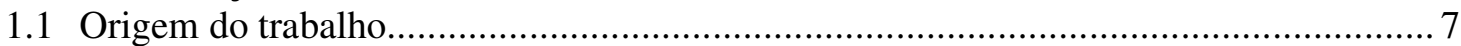

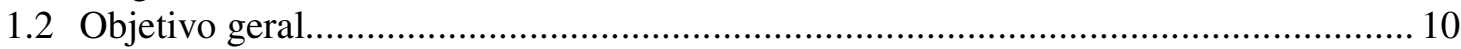

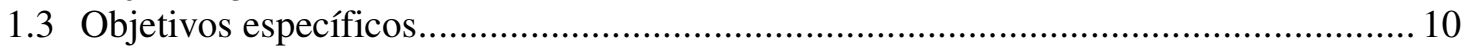

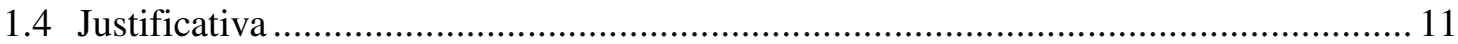

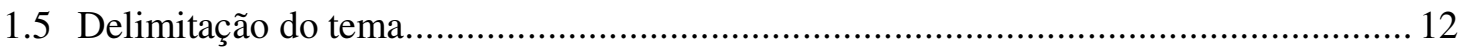

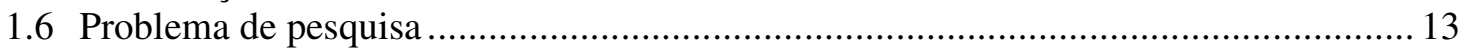

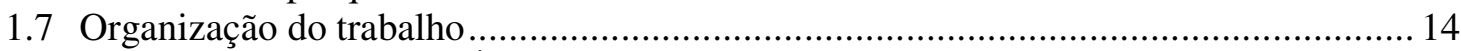

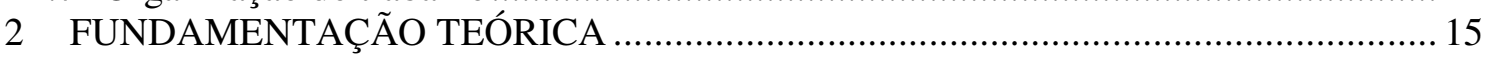

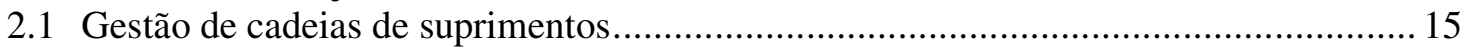

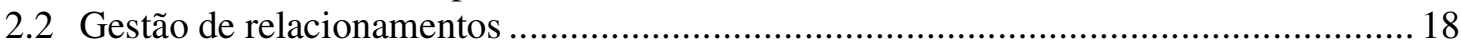

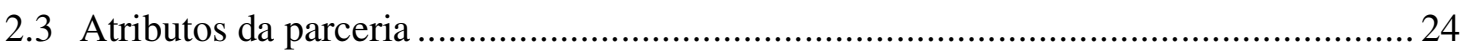

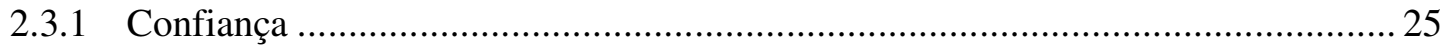

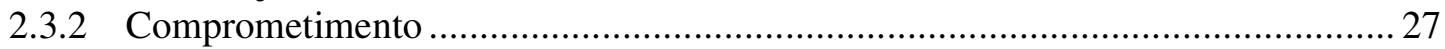

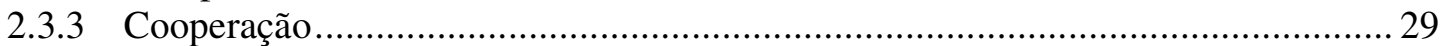

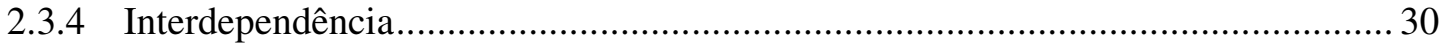

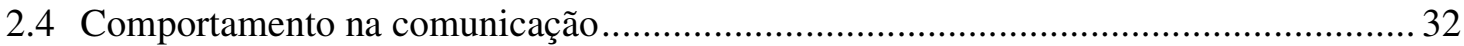

2.4.1 Compartilhamento de informação ...................................................................... 34

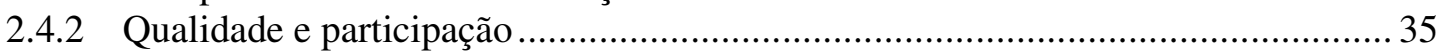

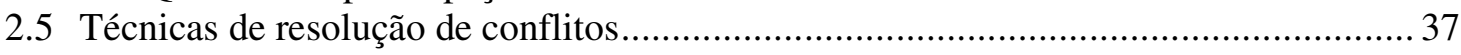

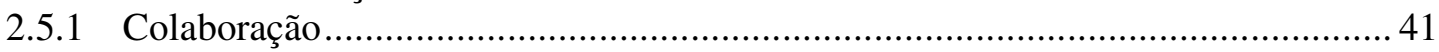

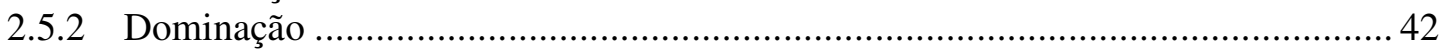

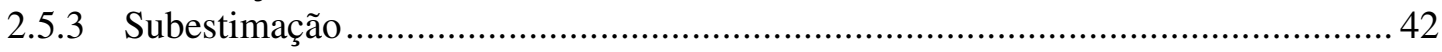

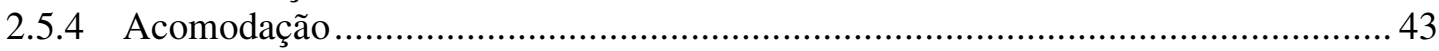

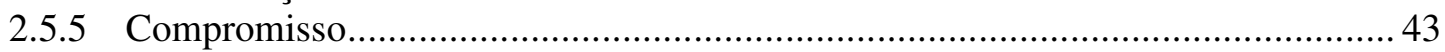

2.6 Sucesso do relacionamento comprador-fornecedor ……........................................... 45

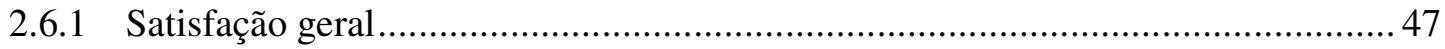

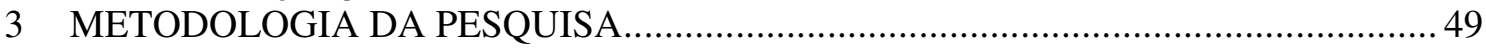

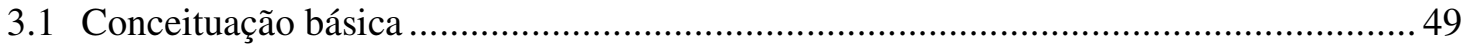

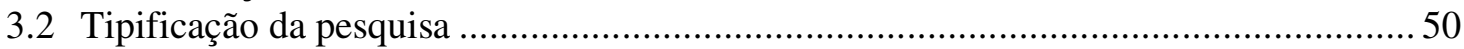

3.3 Coleta de dados

3.3.1 Instrumento de coleta de informações ................................................................. 55

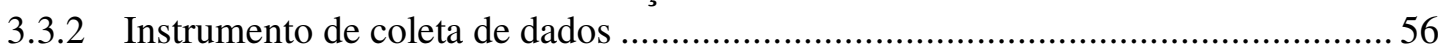

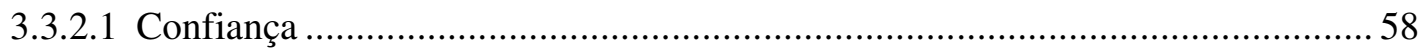

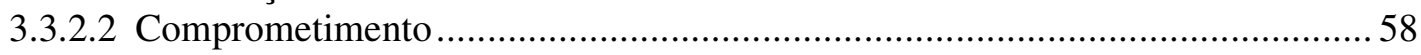

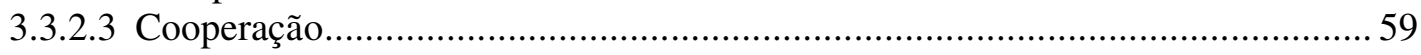

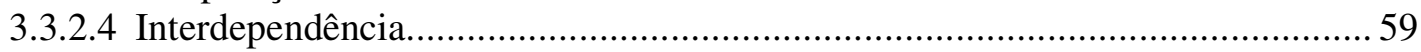

3.3.2.5 Compartilhamento de informação …………………………………………....59

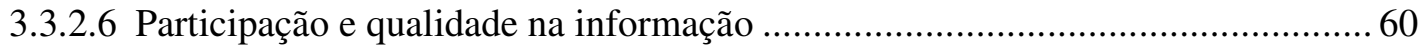

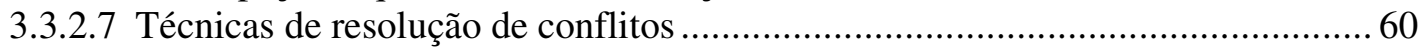

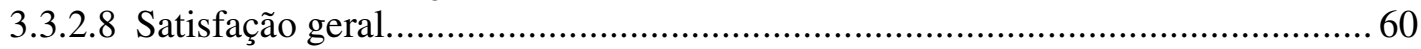

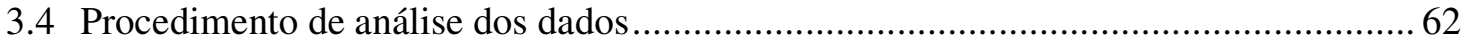

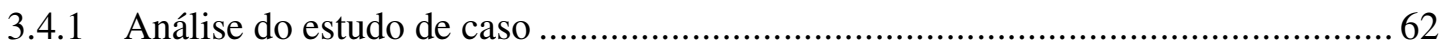

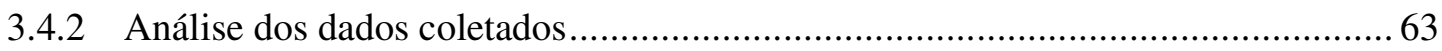




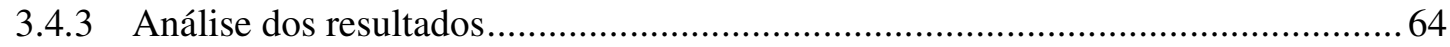

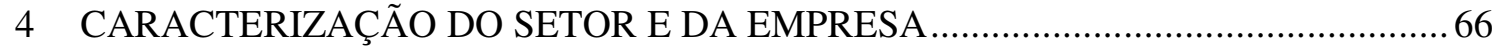

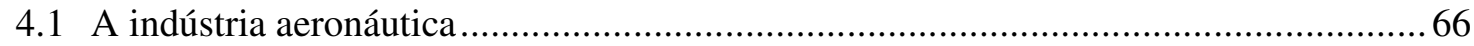

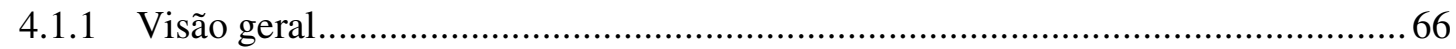

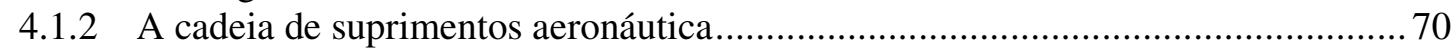

4.1.3 Relacionamentos na indústria aeronáutica ........................................................ 72

4.1.4 A indústria aeronáutica no Brasil ..................................................................... 74

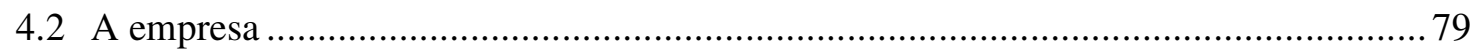

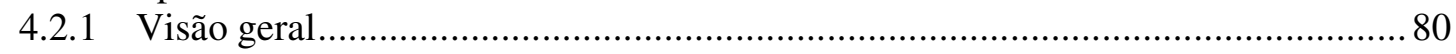

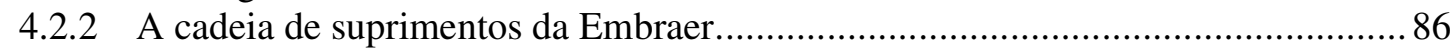

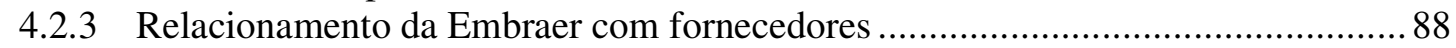

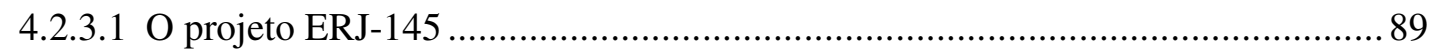

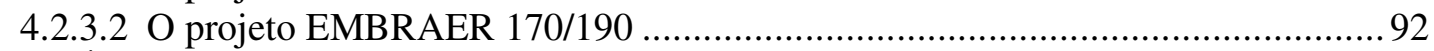

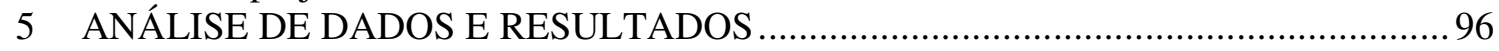

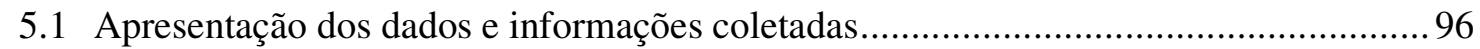

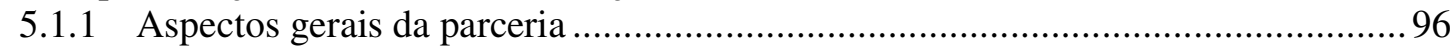

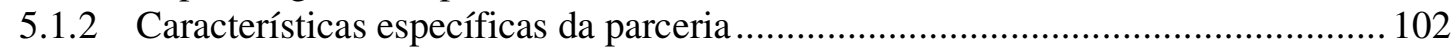

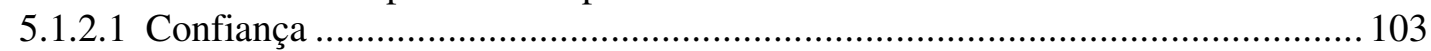

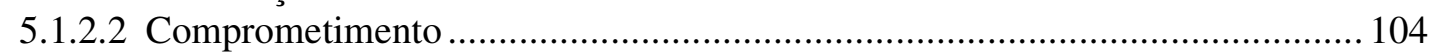

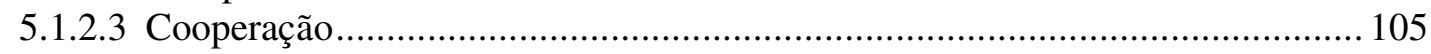

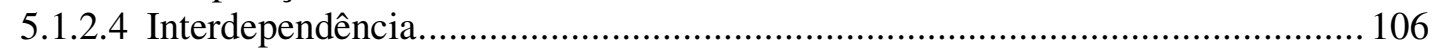

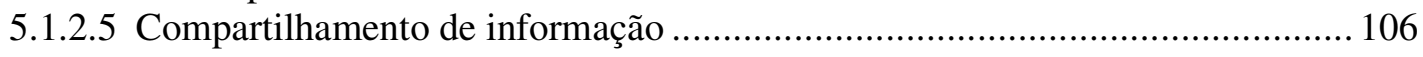

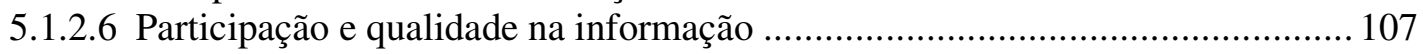

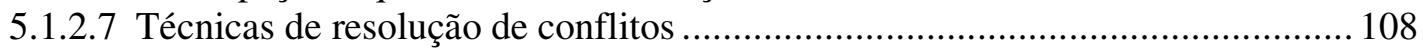

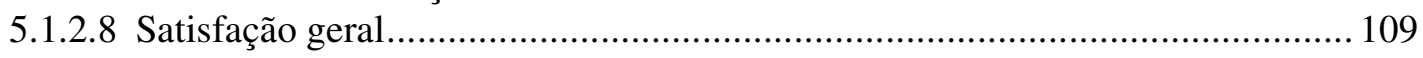

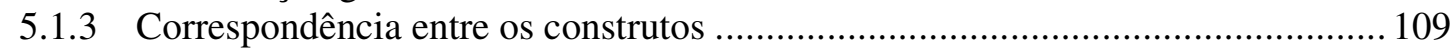

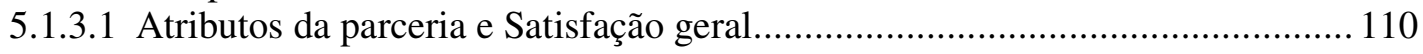

5.1.3.2 Comportamento na comunicação e Satisfação geral ......................................... 111

5.1.3.3 Resolução de conflitos e Satisfação geral ......................................................... 111

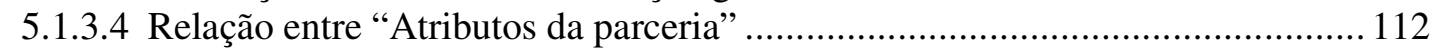

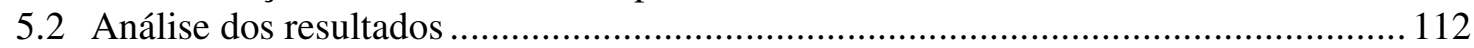

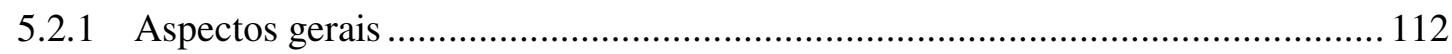

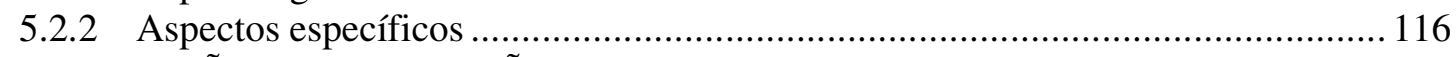

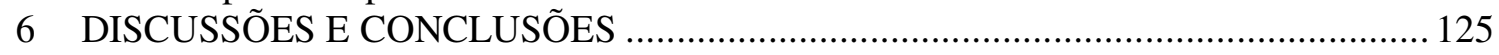

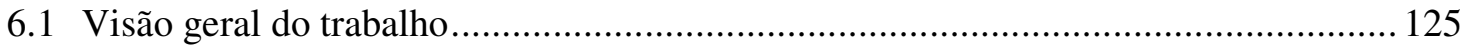

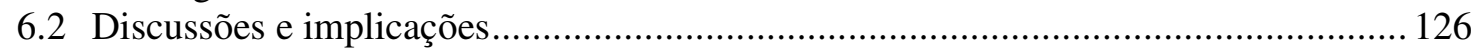

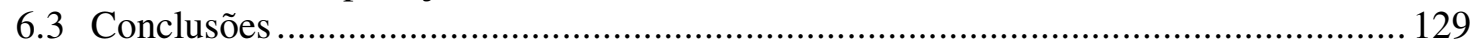

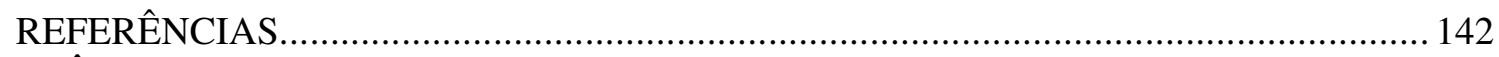

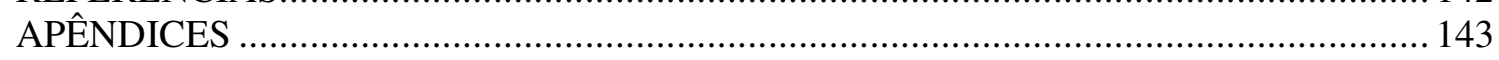

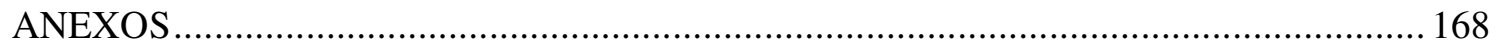




\section{LISTA DE ABREVIATURAS E SIGLAS}

AECMA: European Association of Aerospace Industries

AVIC: Aviation Industries of China

BAE: British Aerospace

BNDES: Banco Nacional de Desenvolvimento Econômico e Social

CPA: Companhia Aeronáutica Paulista

CTA Centro Técnico Aeroespacial

EAC: Embraer Aircraft Company

EADS: European Defense and Space Company

EAMS: Embraer Aircraft Maintenance Services

EAI: Embraer Aviation International

ELEB: Embraer Liebherr Equipamentos do Brasil

EPA: Environmental Protection Agency

EUA: Estados Unidos da América

FAB Força Aérea Brasileira

FMA: Fabrica Militar de Aviones

IPD: Instituto de Pesquisa e Desenvolvimento

IPT: Instituto de Pesquisas Tecnológicas

ISM: Insitute for Supply Management

ITA: Instituto Tecnológico de Aeronáutica

MIT: Massachussets Institute of Technology

OEM: Original Equipment Manufacturer

OGMA: Oficinas Gerais de Material Aeronáutico

SPSS: Statistical Package for the Social Sciences

USP: Universidade de São Paulo 


\section{LISTA DE QUADROS}

Quadro 1 - Características do relacionamento comprador-fornecedor ..........................................20

Quadro 2 - Principais elementos de caracterização de relacionamento em cadeias de suprimentos .... 23

Quadro 3 - Características das abordagens de resolução de conflitos .......................................... 45

Quadro 4 - Condições relevantes para diferentes estratégias de pesquisa .......................................52

Quadro 5 - Fatores críticos de competitividade na indústria de aeronaves civis ................................6 68

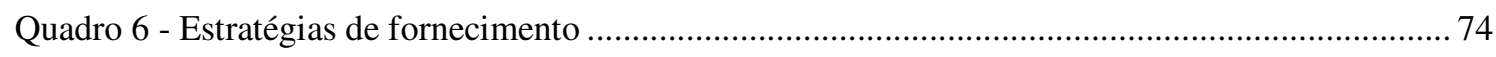

Quadro 7 - Principais eventos na evolução da indústria aeronáutica brasileira (1945 a 1994) .............77

Quadro 8 - Principais eventos na evolução da Embraer pós-privatização ....................................... 81

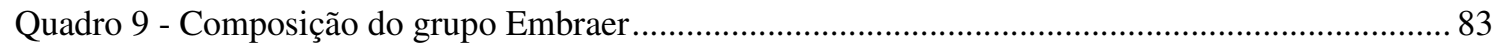

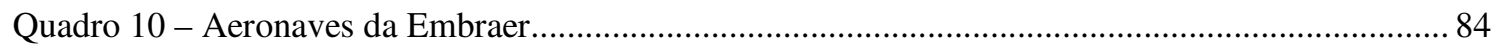

Quadro 11 - Evolução das tecnologias de produto e processo ...................................................... 85 


\section{LISTA DE FIGURAS}

Figura 1 - Atividades e firmas em uma cadeia de suprimentos........................................ 16

Figura 2 - Níveis de pesquisa em gestão da cadeia de suprimentos ...................................... 18

Figura 3 - Parceria como um tipo de relacionamento ..................................................... 19

Figura 4 - Modelo conceitual - Fatores de sucesso ...................................................... 25

Figura 5 - Modelo de Thomas - Cinco abordagens para administrar conflitos ...................... 39

Figura 6 - Modelo de Rahim e Bonoma - Estilos de administração de conflitos ..................... 40

Figura 7 - Uma abordagem sistemática para pesquisa empírica ...................................... 51

Figura 8 - Estrutura da cadeia de suprimentos aeronáutica............................................ 71

Figura 9 - Estrutura Organizacional de Suprimentos da Embraer........................................ 88

Figura 10 - Evolução do modelo de relacionamento da Embraer......................................... 90 


\section{INTRODUÇÃO}

\subsection{Origem do trabalho}

Nas últimas décadas, mudanças rápidas têm ocorrido no mundo dos negócios, influenciadas por fatores como: globalização, crescente competição, aumento do grau de exigência dos clientes e evolução da tecnologia da informação.

Durante os anos 70 e 80, a natureza do ambiente competitivo mudou significativamente, em função da rápida industrialização dos países em desenvolvimento e do surgimento de fortes competidores japoneses e europeus em muitas indústrias (FLAHERTY, 1996). Esse cenário não só continuou, como se agravou dos anos 90 até os dias de hoje, fazendo com que a pressão sobre as empresas pela introdução de novos produtos e por acesso a novas tecnologias, de forma rápida, aumentasse fortemente.

A evolução observada, concomitantemente, nas tecnologias de informação, comunicação e transporte propiciou os meios para que as empresas pudessem desenvolver uma nova configuração organizacional, mais ágil e de menor custo, de forma a responderem ao desafio de manterem sua competitividade global.

De acordo com Jarillo (1993), essas tendências tecnológicas reduzem custos, tornando mais barato coordenar as atividades através das fronteiras da organização, do que por meio de burocracias internas.

A estratégia de integração vertical, predominante entre as empresas industriais, vem dando lugar a uma maior descentralização produtiva, criando um novo padrão de interrelacionamento entre empresas, através do qual elas passam a se concentrar em seu negócio central e desenvolvem outras empresas para executarem as atividades complementares (AMATO NETO, 1995).

Nesta mesma linha, Corrêa e Corrêa $(2004$, p. 91) afirmam que a evolução das tecnologias de produto e processo tem se dado a passos tão rápidos que, para manterem-se atualizadas, as 
empresas têm preferido delegar para terceiros, parcelas cada vez mais substanciais do desenvolvimento e produção de componentes e serviços.

Harland (1996) destaca que uma crescente dependência nos relacionamentos com os fornecedores vem sendo reportada por diversos autores.

Como consequiência, aumentou significativamente a quantidade e a intensidade das relações entre empresas, e estas passaram a conviver com complexas redes de suprimentos, nas quais aspectos de cooperação, desenvolvimento conjunto de produtos, parcerias e alianças tornamse parte integrante do novo modelo de relacionamento entre elas.

As empresas passaram a ser instadas a alterar o modelo tradicional de relacionamento distante e de curto prazo - mercado puro - com seus fornecedores por uma relação colaborativa de longo prazo - parceria.

Essa migração para relacionamentos próximos e de longo prazo foi evidenciada, inicialmente, na indústria automobilística internacional (WOMACK et al, 1992; HELPER, 1995; DYER, 1996; LANGFIELD-SMITH; GREENWOOD, 1998) e tem sido reportada também em outros ramos de atividade: na indústria fotográfica (ELLRAM; EDIS, 1996); na indústria de defesa (HUMPHRIES; WILDING, 2001); na indústria automobilística nacional (DI SERIO; SAMPAIO, 2001; GRISI; RIBEIRO, 2004; CORRÊA; CORRÊA, 2004); na indústria alimentícia (LAMBERT; KNEMEYER, 2004) e na indústria aeroespacial (CHOI; ROSSETTI, 2005; ESPOSITO, 2004).

Essa tendência não significa que o tipo de relacionamento deva ser único, já que não é razoável e nem mesmo exeqüível que as empresas tratem da mesma forma todos os seus fornecedores.

Cooper et al (1997) afirmam que a empresa deve analisar quais relacionamentos são chaves e necessitam ter um vínculo muito próximo (parceria) e quais devem ser administrados sob outra perspectiva, considerando aspectos como comprometimento de tempo, experiência gerencial e características do mercado. 
Lambert e Knemeyer (2004) enfatizam que é alto o custo de desenvolver parcerias e elas só se justificam se o retorno potencial for muito superior ao que seria obtido na sua ausência. Portanto, a empresa deve definir de que forma se relacionará com cada um dos seus fornecedores e necessita estabelecer critérios para tal.

Um modelo de tipos de relacionamento entre fornecedor e cliente foi desenvolvido por Bensaou (1999) baseado em uma pesquisa realizada com empresas automobilísticas japonesas e norte-americanas, através da qual procurou entender como estas empresas se relacionavam com seus fornecedores. Ele concluiu que o nível de especificidade dos investimentos feitos pelo fornecedor e pelo cliente podia ser associado ao tipo de relacionamento utilizado.

Outro modelo, proposto por Corrêa e Corrêa (2004), considera que o tipo de relacionamento desejável seria influenciado pela centralidade da atividade e pelo custo incorrido pelo cliente para substituir o fornecedor, compondo assim um portfólio de relações.

Lambert e Knemeyer (2004) citam modelos empíricos que vem sendo utilizados por algumas empresas, nos quais os fornecedores são distribuídos em uma matriz que relaciona "complexidade para o cliente" com "volume de compra" ou "potencial de redução de custo" com "potencial de inovação".

O que esses modelos têm em comum é o fato de que, à medida que a pontuação em ambos os quesitos aumenta, o tipo de relacionamento mais adequado caminha do modelo tradicional mercado puro, para um modelo cooperativo - parceria.

Parcerias têm como principal motivador a busca por vantagem competitiva e podem propiciar benefícios como: ampliar a gama de produtos/serviços oferecidos; permitir acesso a novos mercados e novas tecnologias; gerar economia de escala; dar acesso a competências complementares; partilhar riscos; obter conhecimento mais amplo. Por outro lado, elas embutem alguns riscos: perda de autonomia; assimetria de informação; aumento de complexidade (MOHR; SPEKMAN, 1994).

Os trabalhos de Sturgeon (2000) e Bronzo (2004) apresentam algumas vantagens das parcerias: maior eficiência quanto à alocação de recursos; melhoria da coordenação dos fluxos 
de informações, entre os agentes econômicos; maior flexibilidade para acomodar a volatilidade dos mercados.

Embora parcerias entre comprador e fornecedor venham se tornando mais comuns, evidências sugerem que muitas têm falhado em atingir seu potencial (LANDEROS et al, 1995).

De acordo com Kale et al (2002), muitos estudos mostram que é difícil alcançar o sucesso nas parcerias e aproximadamente $50 \%$ delas falham e, portanto, compreender o que as empresas podem fazer para aumentar a probabilidade de sucesso das parcerias é importante tanto para pesquisadores como para gestores.

Este trabalho foi originado pela constatação de que a forma como a empresa desenvolve as relações de parceria no contexto de sua cadeia de suprimentos é de fundamental importância para a manutenção da competitividade e de que o entendimento dos elementos presentes em parcerias de sucesso pode auxiliar nas decisões quanto a sua formação, desenvolvimento e manutenção.

\subsection{Objetivo geral}

Contribuir para o entendimento das principais características que devem estar presentes em relacionamentos de parceria bem sucedidos em uma cadeia de suprimentos.

\subsection{Objetivos específicos}

- Identificar os principais atributos das parcerias que podem ser associados ao seu sucesso;

- Descrever um modelo conceitual, já testado empiricamente, que relaciona os fatores presentes em parcerias de sucesso;

- Verificar a presença dos atributos componentes deste modelo na relação fabricantefornecedor em uma indústria aeronáutica brasileira. 


\subsection{Justificativa}

O conceito de gestão da cadeia de suprimentos (supply chain management) veio a público pela primeira vez em 1982 por meio de um artigo publicado pelo jornal Financial Times (BOOZ ALLEN HAMILTON, 2003).

Já Corrêa e Corrêa (2004, p. 94) assinalam que o movimento de supply chain management inicia-se em 1985 e que até então, historicamente, as ações de melhoria de desempenho vinham sendo concentradas internamente às empresas, fazendo com que esforços crescentes nesse sentido levassem a retornos decrescentes.

As empresas passaram a perceber que esforços colocados em melhorias no relacionamento entre elas trazem um retorno comparativamente muito mais alto e descobrem que a gestão eficiente da cadeia de suprimentos é o próximo passo que precisa ser dado para aumentar lucros e participação de mercado (SIMCHI-LEVI et al, 2000, p.5).

Em resumo, o crescente interesse pelo tema advém dos seguintes pontos citados por Lummus e Vokurka (1999):

- Poucas empresas continuam atuando verticalmente integradas; elas tornaram-se mais especializadas e gerir seu relacionamento com fornecedores passa a ser crítico;

- $\quad$ Múltiplas fontes capazes de satisfazer a demanda do mercado acirraram a competição;

- A maximização do desempenho de uma empresa individualmente tende a não otimizar o resultado da cadeia de suprimentos como um todo.

Segundo Simchi-Levi et al (2000, p.8): "Muitos problemas em cadeias de suprimentos são novos e não existe um entendimento claro de todas as questões envolvidas."

Portanto, este trabalho pode ser justificado considerando que a gestão da cadeia de suprimentos e do relacionamento entre seus agentes é um campo de conhecimento amplo, relativamente recente e que vem despertando crescente interesse.

\footnotetext{
1 "Many supply chain problems are new and there is no clear understanding of all of the issues involved."
} 
Mais especificamente, em consonância com o objetivo deste trabalho, vale ressaltar a colocação de Tan (2001): “[...] existe uma falta de modelos empíricos para estabelecer uma parceira de sucesso comprador-fornecedor.",2

O propósito deste trabalho é colaborar para a compreensão dos elementos contribuintes para o sucesso de parcerias fabricante-fornecedor através do teste empírico, em uma indústria aeronáutica, de um modelo já testado em outros setores produtivos e adaptado da literatura pesquisada, o qual incorpora esses determinantes de sucesso.

\subsection{Delimitação do tema}

Este trabalho não aborda profundamente todos os aspectos relacionados com a gestão da cadeia de suprimentos, dando maior atenção à gestão de relacionamentos. Além disso, não busca analisar exaustivamente os modelos de relacionamento entre empresas, não abordando os relacionamentos colaborativos entre concorrentes.

Restringe-se a estudar as relações de parceria entre agentes das cadeias de suprimentos.

O termo "gestão da cadeia de suprimentos" pode ser usado para descrever as atividades de compra e fornecimento de empresas de manufatura, as funções de transporte e logística de distribuidores e varejistas, bem como todas as atividades que agregam valor desde o explorador da matéria-prima até o usuário final, incluindo reciclagem (TAN, 2001).

Este trabalho foca especificamente na relação entre manufatura e fornecedor, buscando identificar atributos que caracterizem uma parceria de sucesso.

A literatura sugere um conjunto de características presentes em relacionamentos compradorfornecedor bem sucedidos, o qual permite compor um modelo conceitual.

Não se pretende criar um modelo, mas adaptar um já testado empiricamente para a situação que será objeto do presente estudo.

\footnotetext{
2 “[...] there is a lack of empirical models for establishing a successful buyer-supplier partnership.”
} 
O modelo incorpora três categorias de características comportamentais consideradas indutoras do sucesso de relacionamentos comprador-fornecedor: atributos da parceria, comportamento na comunicação e técnicas de resolução de problemas.

O modelo utilizado neste trabalho baseia-se em duas premissas: os relacionamentos de parceria comprador-fornecedor contêm um conjunto de características que os distingue dos relacionamentos tradicionais e as parcerias de sucesso apresentam essas características com maior intensidade (MOHR; SPEKMAN, 1994; MONCZKA et al, 1998b).

Este trabalho estabelece que a unidade de análise para testar o modelo conceitual é o relacionamento entre uma indústria aeronáutica e um grupo de fornecedores com o qual a empresa considera que tenha desenvolvido uma parceria, para uma família específica de produtos.

A discussão neste trabalho será restrita à percepção do fabricante (indústria aeronáutica) quanto a este relacionamento de parceria. A tentativa de obter a visão correspondente dos fornecedores envolvidos estaria comprometida considerando que este autor, além de pertencer ao quadro funcional da empresa pesquisada, tem um cargo gerencial na área de suprimentos com ação executiva direta sobre os respectivos fornecedores, o que afetaria a objetividade dos mesmos.

Por ser um estudo desenvolvido dentro de um contexto específico, os resultados não podem ser generalizados ou extrapolados.

\subsection{Problema de pesquisa}

Considerando a existência de parceria em um relacionamento fabricante-fornecedor em uma indústria aeronáutica, verificar a presença ou não das características comportamentais previstas na literatura para parcerias bem sucedidas, o que pode ser resumido nas seguintes questões: 
1) Como os atributos da parceria estão associados ao sucesso do relacionamento comprador-fornecedor?

2) Como o comportamento na comunicação está relacionado com o sucesso da parceria?

3) Quais tipos de técnicas de resolução de conflitos contribuem para o sucesso da parceria?

\subsection{Organização do trabalho}

Este trabalho está organizado em seis capítulos.

Neste Capítulo 1 (Introdução), apresenta-se a origem do trabalho, o objetivo geral e específico, a justificativa, a delimitação do tema, o problema de pesquisa e a estrutura.

O Capítulo 2 (Fundamentação Teórica) expõe a literatura sobre gestão de cadeias de suprimentos e gestão de relacionamentos. Descreve os conceitos de cadeia de suprimentos, de sua gestão e dos atributos presentes nos relacionamentos comprador-fornecedor. Em seguida, discute o conjunto de características indutoras do sucesso de parcerias entre comprador e fornecedor e o modelo conceitual correspondente.

No Capítulo 3 (Metodologia da Pesquisa) é feita a tipificação da pesquisa, são apresentadas as proposições desse estudo derivadas da literatura e do modelo adotado, bem como os instrumentos de pesquisa para coleta dos dados e o procedimento para análise dos dados.

O Capítulo 4 (Caracterização do setor e da empresa) descreve as características da empresa pesquisada e do setor no qual ela está inserida, bem como a gestão da cadeia de suprimentos e dos relacionamentos presentes nos mesmos.

No Capítulo 5 (Análise de dados e Resultados) as informações coletadas e os resultados obtidos são apresentados, sendo feita sua confrontação com as proposições apresentadas.

O Capítulo 6 (Discussões e Conclusões) sumariza os resultados do trabalho, discute os mesmos à luz da literatura e das proposições postas inicialmente e apresenta as conclusões. Em seguida, elabora uma discussão sobre as implicações dos resultados obtidos, sobre as limitações do trabalho e sobre contribuições para estudos futuros.

As referências bibliográficas são apresentadas em capítulo próprio, assim como os apêndices e anexos. 


\section{FUNDAMENTAÇÃO TEÓRICA}

Este capítulo faz uma revisão dos conceitos presentes na literatura quanto aos relacionamentos em cadeias de suprimentos. Faz uma discussão da teoria mais relevante e de estudos anteriores sobre atributos indutores de parcerias de sucesso. O capítulo apresenta os construtos que têm sido estudados e descreve sua relação com o sucesso de relacionamentos entre fabricante e fornecedor. Em seguida, cada um dos construtos - atributos da parceria, comportamento na comunicação e técnicas de resolução de conflitos, e seus componentes são descritos mais detalhadamente. Conclui propondo a satisfação geral como uma forma adequada de dimensionar o sucesso de uma parceria.

\subsection{Gestão de cadeias de suprimentos}

Segundo Coase (1937), para compreender a atividade de uma empresa, primeiro deve-se entender porque ela existe.

Thorelli (1986) argumenta que as organizações existem em função de economias de escala e de especialização e pela capacidade em reduzir custos de transações, o que resulta em uma divisão do trabalho manifestada através de uma grande variedade de arranjos institucionais, formando um espectro onde de um lado está o mercado aberto e no outro extremo a empresa integrada verticalmente. Essa divisão do trabalho implica que cada empresa tem um escopo definido em termos de: produto/serviço ofertado, clientes atendidos, funções executadas, território, tempo e objetivos específicos a atingir.

A cadeia de suprimentos pode ser entendida como um arranjo compreendido entre os dois extremos acima e estará presente sempre que houver sobreposição de escopo entre pelo menos duas empresas.

A definição de cadeia de suprimentos apresenta amplitudes diferentes na literatura. 
Alguns autores a descrevem de forma restrita como consistindo de todas as atividades envolvidas na transformação de matéria-prima em produto acabado e a entrega deste ao cliente (FLAHERTY, 1996; MONCZKA et al, 1998a, p.5; LUMMUS; VOKURKA, 1999).

Já Chopra e Meindl (2001, p. 3) generalizam ao afirmar que uma cadeia de suprimentos é formada por todos os estágios, direta ou indiretamente, envolvidos em atender ao pedido do cliente.

Por outro lado, Cox et al (2001) trazem uma definição mais específica e abrangente: cadeia de suprimentos é uma rede ampliada de relacionamentos bilaterais de troca que cria algum produto ou serviço a ser fornecido ao cliente final. O produto ou serviço passa por uma série de estágios de troca entre comprador e fornecedor, nos quais sofre alguma forma de transformação e agregação de valor.

Ampliando um pouco mais o conceito, Tan (2001) inclui as atividades de extração de matériaprima e reciclagem de produtos, quando aplicável, conforme esquematizado na Figura 1.

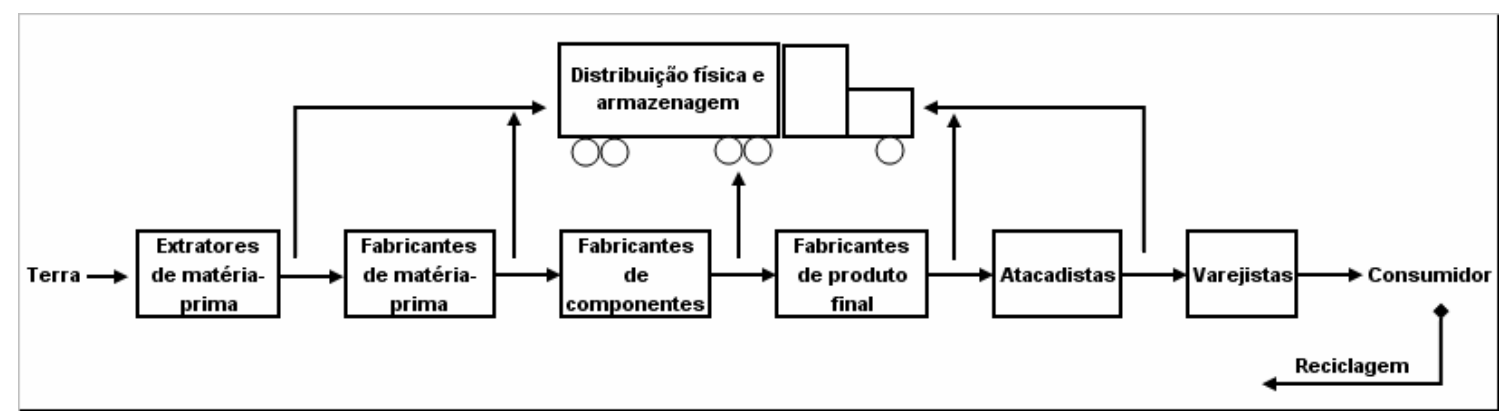

Figura 1 - Atividades e firmas em uma cadeia de suprimentos Fonte: TAN, 2001.

A existência de um fluxo de informações e financeiro, em ambas as direções, entre os estágios da cadeia de suprimentos é explicitada na definição apresentada por Mentzer (2001, p. 5) e na complementação do conceito exposto acima por Chopra e Meindl (2001, p. 4).

Fica evidente, que por envolver um fluxo constante de produtos, serviços, informações e fundos entre estágios, a cadeia de suprimentos tem um caráter dinâmico. Fisher (1997) destaca este aspecto quando associa a estrutura e o foco operacional da cadeia de suprimentos com as características do produto e seu ciclo de vida. 
Em sentido semelhante, Fine (1999, p.96) argumenta que esta dinâmica está relacionada à velocidade evolutiva das tecnologias e dos produtos presentes na cadeia de suprimentos e também ao fenômeno da distorção da demanda ao longo dos estágios, conhecido como efeito chicote ou Forrester.

Todas essas atividades e características componentes de uma cadeia de suprimentos, associadas à existência de várias empresas interagindo em cada estágio, deixam claro a complexidade desse arranjo e a importância de sua gestão. Uma competência essencial da empresa está na habilidade de planejar e gerenciar a cadeia de suprimentos (FINE, 1999, p.84).

De acordo com Harland (1996), o termo "gestão da cadeia de suprimentos" surgiu no início dos anos 80, tem sido usado com pouca consistência em diversas áreas de conhecimento e tem apresentado pouca evidência quanto à clareza de significado. As definições variam entre autores e sugerem que o termo representa uma fonte de confusão para os interessados em pesquisar o fenômeno (MENTZER, 2001, p. 9).

Harland (1996) considera que existem quatro usos principais para o termo "gestão da cadeia de suprimentos": a integração das funções de negócio envolvidas no fluxo de materiais e informação através da cadeia de suprimentos interna; a gestão do relacionamento bilateral da empresa com seus fornecedores imediatos; a gestão de uma cadeia de negócios incluindo fornecedores e clientes de todos os níveis; e a gestão de uma rede de negócios interconectados envolvidos em entregar o pacote de valor requerido pelo cliente final.

A Figura 2 abaixo representa essa visão que, segundo Harland (1996), está associada aos diferentes níveis sistêmicos de análise que vem sendo utilizados pelas pesquisas e pelos desenvolvimentos conceituais sobre o tema "gestão da cadeia de suprimentos".

Christopher (1997) considera a gestão da cadeia de suprimentos como uma alternativa para a integração vertical e Harland (1996) afirma que as pesquisas têm evoluído no sentido de discutir a gestão da cadeia de suprimentos como um tipo de relacionamento intermediário dentro de um espectro que varia da integração vertical ao mercado puro. 


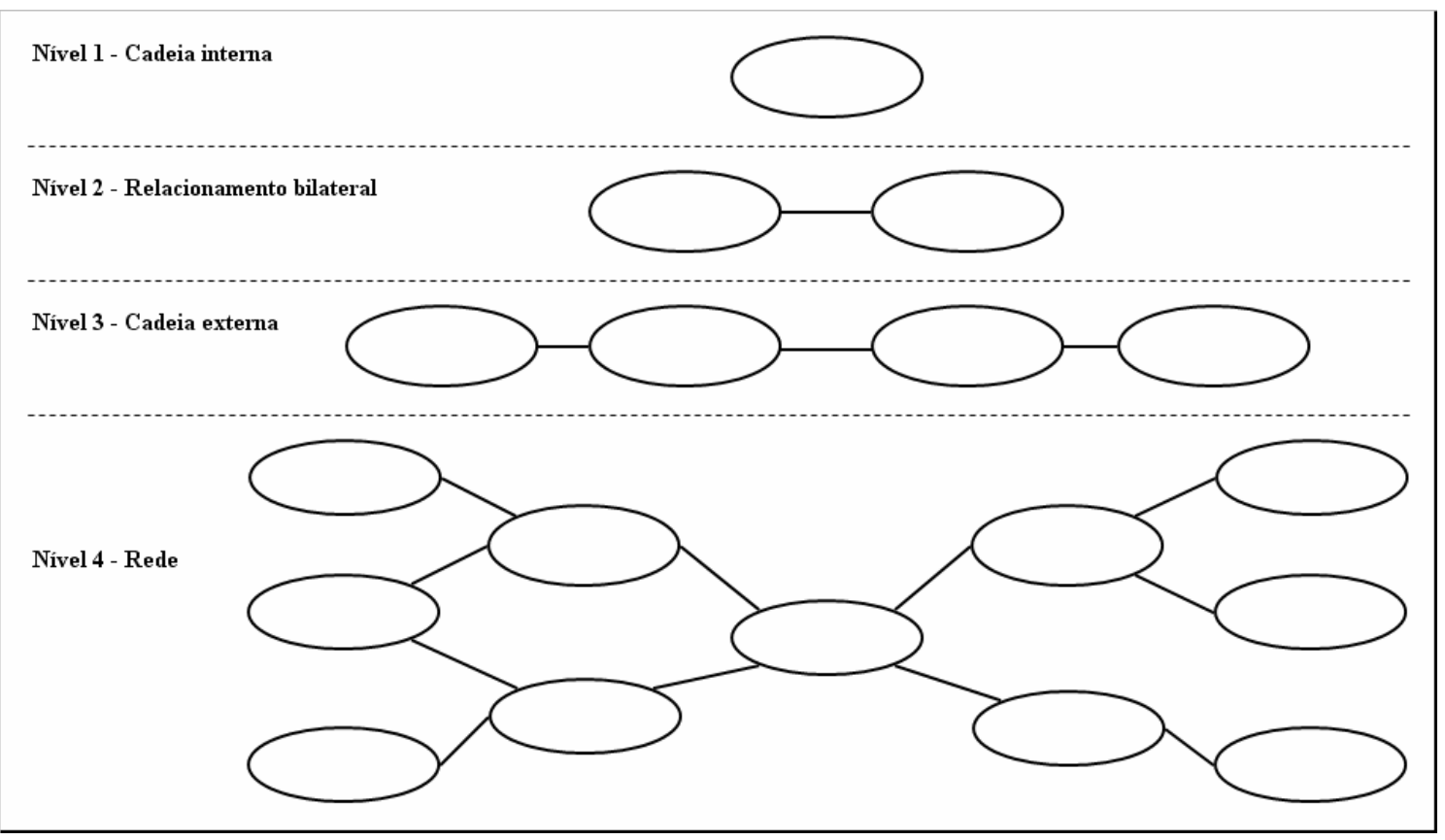

Figura 2 - Níveis de pesquisa em gestão da cadeia de suprimentos Fonte: HARLAND, 1996.

Para efeito deste trabalho, foi adotada a visão da gestão do relacionamento bilateral da empresa com seus fornecedores imediatos, representado pelo nível 2 da figura acima.

\subsection{Gestão de relacionamentos}

O crescente interesse pela gestão de relacionamentos em cadeias de suprimentos ocorre em função das diferentes tendências que vem sendo observadas nos negócios, tais como: desintegração vertical, redução da base de fornecedores, focalização, terceirização, "just in time" e parcerias (HARLAND, 1996).

Essas tendências resultam da forte pressão exercida sobre os negócios por fatores como: escassez de recursos, crescente competição, globalização dos mercados, mudanças rápidas e alta expectativa dos clientes (HUMPHRIES; WILDING, 2001).

Estes fatores têm impulsionado as empresas a buscarem relacionamentos mais próximos e de longo prazo - parcerias - com os membros de sua cadeia de suprimentos, objetivando: compartilhar incertezas e custos, ter acesso a tecnologias complementares, aprender novas 
tecnologias, adquirir novas competências, criar valor sinérgico, reduzir tempo para inovações, monitorar mudanças ambientais, entrar em mercados estrangeiros e expandir a gama de produtos (GULATI, 1995; DOZ, 2000).

Segundo Mentzer et al (2000), a gestão da cadeia de suprimentos é o gerenciamento de relacionamentos próximos entre empresas e compreender parceria é importante para desenvolver relacionamentos bem sucedidos em cadeias de suprimentos.

Uma parceria ocorre através de vínculos sociais, econômicos e técnicos que se estendem ao longo do tempo e requer comprometimento mútuo, confiança e metas comuns, assim como comunicação intensa e cooperação (MORGAN; HUNT, 1994; MENTZER et al, 2000).

Alguns autores, como Webster (1992) e Harland (1996), referem-se à parceria como um tipo intermediário de relacionamento dentro de um espectro abrangendo da integração vertical até o mercado puro, como mostra a Figura 3.

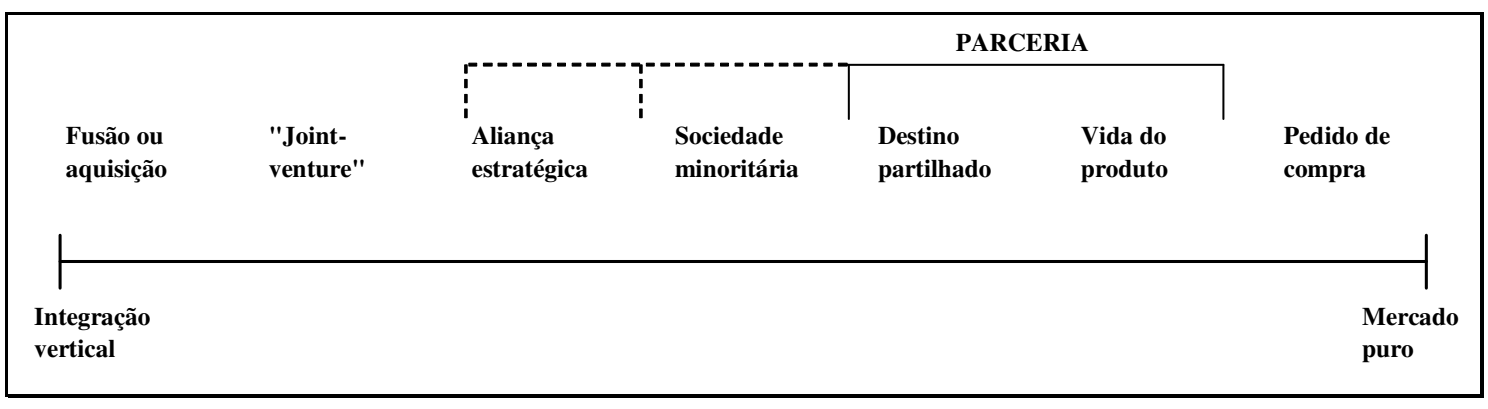

Figura 3 - Parceria como um tipo de relacionamento Fonte: HARLAND, 1996.

Segundo Monczka et al (1998a), parcerias são relacionamentos colaborativos que envolvem um alto nível de cooperação, visão de longo prazo, comprometimento mútuo, relação balanceada de poder e incluem mecanismos para gerenciar conflitos. No Quadro 1 é apresentada uma análise comparativa entre as abordagens tradicional e colaborativa quanto às características do relacionamento comprador-fornecedor, na visão desses autores.

Humphries e Wilding (2001) analisam a visão de diversos autores e concluem que parceria é uma abordagem holística para a gestão da cadeia de suprimentos, envolvendo tecnologia, processo e informação e baseada em confiança e comprometimento de longo prazo, tendo como meta final assegurar melhores retornos financeiros para todos os membros da cadeia. 
Quadro 1 - Características do relacionamento comprador-fornecedor

\begin{tabular}{|l|l|l|}
\hline & Abordagem tradicional & Abordagem colaborativa \\
\hline Fornecedores & $\begin{array}{l}\text { Fontes múltiplas colocadas } \\
\text { umas contra as outras }\end{array}$ & $\begin{array}{l}\text { Poucos fornecedores } \\
\text { preferenciais }\end{array}$ \\
\hline Partilha de custos & $\begin{array}{l}\text { Comprador fica com os } \\
\text { ganhos; fornecedor esconde } \\
\text { as reduções de custos }\end{array}$ & $\begin{array}{l}\text { Divisão de benefícios; } \\
\text { abordagem ganha/ganha }\end{array}$ \\
\hline $\begin{array}{l}\text { Esforços conjuntos de } \\
\text { melhoria }\end{array}$ & Poucos ou nenhum & $\begin{array}{l}\text { Dirigidos por mútua } \\
\text { interdependência }\end{array}$ \\
\hline Resolução de conflitos & $\begin{array}{l}\text { Comprador decide de forma } \\
\text { unilateral }\end{array}$ & $\begin{array}{l}\text { Existência de mecanismos de } \\
\text { solução }\end{array}$ \\
\hline Comunicação & $\begin{array}{l}\text { Mínima ou sem troca de } \\
\text { informação em duas vias }\end{array}$ & $\begin{array}{l}\text { Aberta e completa troca de } \\
\text { informações }\end{array}$ \\
\hline Ajustes de mercado & $\begin{array}{l}\text { Comprador determina } \\
\text { resposta às mudanças }\end{array}$ & $\begin{array}{l}\text { Trabalho conjunto para } \\
\text { adaptação à mudança }\end{array}$ \\
\hline Qualidade & Inspeção no recebimento & $\begin{array}{l}\text { Projetada no produto e no } \\
\text { processo }\end{array}$ \\
\hline
\end{tabular}

Fonte: MONCZKA et al, 1998a.

Parceria pode ser definida como uma forma de relacionamento entre duas organizações independentes, caracterizada por um compromisso de longo prazo baseado em confiança mútua e alto nível de interdependência, envolvendo compartilhamento de metas compatíveis, de informação, de riscos e de recompensas, e gerando uma vantagem competitiva que resulta em um desempenho melhor do que seria alcançado pelas empresas individualmente (MOHR; SPEKMAN, 1994; LAMBERT et al, 1999; ELLRAM, 1995; LEMKE et al, 2003).

Muito tem sido escrito sobre os vários aspectos do relacionamento comprador-fornecedor, baseado neste novo paradigma: parceria como suporte aos objetivos estratégicos da empresa; fatores para seleção de parceiros; implantação e desenvolvimento de parcerias; tendências nos tipos de parceria; barreiras e fatores de sucesso em parcerias; características que distinguem parceria de outras formas de relacionamento; taxas de sucesso de parcerias (ELLRAM, 1995; ELLRAM; HENDRICK, 1995).

No entanto, um número limitado de pesquisas tem examinado os fatores que estão por trás de parcerias comprador-fornecedor que tiveram sucesso (LANDEROS et al, 1995).

$\mathrm{Na}$ literatura sobre relacionamento comprador-fornecedor, o estudo de Dwyer et al (1987) é um dos mais citados. Eles apresentam um modelo conceitual que trata o relacionamento 
comprador-fornecedor pela perspectiva do comportamento organizacional. O modelo define cinco fases para representar como as partes interagem em um relacionamento bilateral:

1) Conscientização - reconhecimento de que a outra parte é um parceiro potencial;

2) Exploração - processo de teste e avaliação do parceiro. Engloba os sub-processos de atração, comunicação e barganha, poder e justiça, desenvolvimento de normas, e desenvolvimento de expectativas;

3) Expansão - aumento contínuo dos benefícios obtidos pelos parceiros, crescimento da interdependência e da motivação para manter o relacionamento;

4) Comprometimento - promessa implícita ou explícita de continuidade da relação;

5) Dissolução - possibilidade de descontinuidade, durante as fases anteriores, por não haver mais interesse de uma das partes.

O modelo de Dwyer et al (1987) revela os atributos considerados importantes para a evolução da parceria e que estão integrados a cada uma das fases acima: confiança, comprometimento, coordenação, interdependência, vínculo entre as partes e gestão de conflitos. Além disso, este modelo pode ser generalizado para diferentes tipos de relacionamentos entre empresas e usado como referência para pesquisas dentro de outros contextos.

Graham et al (1994) desenvolveram uma pesquisa para examinar a relação entre o tempo de existência da parceria e o grau de sucesso na implantação de estratégias de compras. Eles referem-se aos fatores críticos de sucesso associados às parcerias como sendo: escolha seletiva, partilha de informações, especificação de papéis, definição de regras básicas, desenvolvimento de provisões para dissolução, comprometimento de longo prazo.

Ellram e Hendrick (1995) pesquisaram empresas na área industrial para obter de ambas as partes, comprador e fornecedor, o ponto de vista quanto às características da parceria em que estavam envolvidas. A conclusão a que chegaram foi que parcerias são caracterizadas por: orientação de longo prazo, compartilhamento de riscos (abordagem ganha/ganha), comunicação excelente, lealdade mútua, negociação de conflitos, troca de informações e melhoria contínua.

Alguns outros trabalhos apresentam construtos que caracterizam os relacionamentos colaborativos entre comprador-fornecedor, os quais incluem variáveis como: comprometimento, confiança, cooperação, interdependência, adaptação, satisfação, troca 
formal/informal de informações, atividades conjuntas, longevidade, gestão de conflito e metas conjuntas (ANDERSON; NARUS, 1990; WILSON, 1995; LINDGREEN, 2003; MONCZKA et al, 1995).

Vários dos elementos ou variáveis que caracterizam os relacionamentos de parceria em cadeias de suprimentos são recorrentes entre os diversos autores pesquisados que abordam esse tema. O Quadro 2 apresenta uma sumarização das características e parâmetros observados com mais freqüência na literatura.

Os estudos até aqui apresentados exploram diversos aspectos dos relacionamentos de parceria entre comprador e fornecedor, e revelam diversas características presentes nestes relacionamentos. No entanto, pouca atenção é dada a como essas características estão diretamente associadas com o sucesso das parcerias.

Nesse sentido, Mohr e Spekman (1994) propuseram um modelo baseado em duas premissas: parcerias contêm um conjunto de características comportamentais que as distingue dos relacionamentos tradicionais e parcerias de sucesso apresentam estas características com maior intensidade. O modelo foi testado empiricamente sob a ótica da percepção do distribuidor, no contexto da parceria fabricante-distribuidor na indústria de computadores. A análise dos resultados indicou que as variáveis significativas para prever o sucesso da parceria são: coordenação, comprometimento, confiança, qualidade da comunicação, compartilhamento de informação, participação, solução conjunta de problemas e evitar o uso de táticas agressivas na gestão de conflitos.

Monczka et al (1998b) desenvolveram um estudo baseado em uma adaptação do modelo de Mohr e Spekman (1994) e coletando os dados entre mais de 200 empresas representando uma grande gama de indústrias, focando na relação com o fornecedor, sob a ótica do fabricante. Os resultados obtidos quanto às variáveis significativas para prever o sucesso da parceria foram consistentes com aqueles de Mohr e Spekman (1994). 
Quadro 2 - Principais elementos de caracterização de relacionamento em cadeias de suprimentos

\begin{tabular}{|c|c|c|}
\hline $\begin{array}{l}\text { Elementos de } \\
\text { caracterização }\end{array}$ & Parâmetros & Definição dos elementos \\
\hline $\begin{array}{l}\text { Estratégia de } \\
\text { colaboração }\end{array}$ & $\begin{array}{l}\text { cooperação } \\
\text { envolvimento } \\
\text { proximidade } \\
\text { força } \\
\text { respeito } \\
\text { reciprocidade } \\
\text { mutualismo } \\
\text { ganha-ganha } \\
\text { solidariedade } \\
\text { justiça } \\
\text { liderança } \\
\end{array}$ & $\begin{array}{l}\text { Crença de que através de relacionamentos fortes e próximos, } \\
\text { baseados na reciprocidade e solidariedade, serão alcançadas } \\
\text { mais vantagens, para os direta e indiretamente envolvidos, do } \\
\text { que em transações oportunistas. }\end{array}$ \\
\hline Comunicação & $\begin{array}{l}\text { informação } \\
\text { abertura } \\
\text { acessibilidade } \\
\text { transparência/clareza } \\
\text { honestidade } \\
\text { expectativas }\end{array}$ & $\begin{array}{l}\text { Passagem de informação com o nível máximo de honestidade e } \\
\text { transparência permitido. A comunicação é imprescindível para o } \\
\text { desenvolvimento e manutenção dos relacionamentos por ser } \\
\text { veículo de expectativas e estar presente em todas as ações } \\
\text { desenvolvidas pelos atores. }\end{array}$ \\
\hline Confiança & $\begin{array}{l}\text { atração } \\
\text { reputação } \\
\text { credibilidade } \\
\text { segurança }\end{array}$ & $\begin{array}{l}\text { Crença de que o outro parceiro atuará sempre em benefício } \\
\text { mútuo dentro do espírito de colaboração. Provém, num primeiro } \\
\text { momento, da atração, reputação e credibilidade sendo reforçada } \\
\text { pela comunicação até a percepção de segurança ser superior à } \\
\text { dos riscos. }\end{array}$ \\
\hline Interação & $\begin{array}{l}\text { multidisciplinariedade } \\
\text { disponibilidade } \\
\text { adaptabilidade } \\
\text { competências } \\
\text { coordenação } \\
\text { sincronização } \\
\text { formalidade/informalidade } \\
\text { valores e cultura }\end{array}$ & $\begin{array}{l}\text { Processo formal e informal de troca e adaptação entre pessoas } \\
\text { das organizações envolvidas, com máxima disponibilidade e } \\
\text { multidisciplinariedade, com vista à coordenação e sincronização } \\
\text { de competências. }\end{array}$ \\
\hline $\begin{array}{l}\text { Comprometi- } \\
\text { mento }\end{array}$ & $\begin{array}{l}\text { responsabilidade } \\
\text { longo prazo/continuidade } \\
\text { maturidade } \\
\text { consistência } \\
\text { persistência } \\
\text { motivação }\end{array}$ & $\begin{array}{l}\text { Crença de que um relacionamento vale o esforço e o empenho } \\
\text { necessários à sua duração, acreditando que a continuidade e a } \\
\text { maturidade são necessárias para extrair todo seu potencial } \\
\text { sucesso. Resulta do conjunto de atitudes e ações compostas por } \\
\text { todos os elementos apresentados no quadro e os impacta. }\end{array}$ \\
\hline Poder & $\begin{array}{l}\text { influência } \\
\text { controle } \\
\text { barganha } \\
\text { autonomia }\end{array}$ & $\begin{array}{l}\text { Capacidade que cada um dos atores tem de conduzir os } \\
\text { processos de negociação e exercer influência nas decisões. }\end{array}$ \\
\hline Conflito & $\begin{array}{l}\text { flexibilidade } \\
\text { legalidade } \\
\text { contratos } \\
\text { normas }\end{array}$ & $\begin{array}{l}\text { Incompatibilidades de interesses entre os parceiros que surgem } \\
\text { no decorrer das negociações. O que se espera é que os parceiros } \\
\text { sejam capazes de negociar soluções usando flexibilidade, sem } \\
\text { ter que fazer uso de cláusulas legais. A resolução de conflitos } \\
\text { contribui para fortalecer todos os elementos até aqui tratados e } \\
\text { potencializar conhecimento. }\end{array}$ \\
\hline Aprendizado & $\begin{array}{l}\text { conhecimento } \\
\text { sinergia } \\
\text { inovação }\end{array}$ & $\begin{array}{l}\text { Processo de troca de conhecimentos efetuado através do uso de } \\
\text { sinergias na interação, negociação e resolução de conflitos, que } \\
\text { resulta num novo conhecimento. }\end{array}$ \\
\hline $\begin{array}{l}\text { Interdepen- } \\
\text { dência }\end{array}$ & $\begin{array}{l}\text { investimento } \\
\text { bens dedicados } \\
\text { estruturas } \\
\text { risco }\end{array}$ & $\begin{array}{l}\text { Grau de indispensabilidade ou insubstituabilidade que um } \\
\text { parceiro atinge ao outro a partir da operacionalização dos } \\
\text { acordos, através dos investimentos tangíveis e intangíveis } \\
\text { aplicados no relacionamento. }\end{array}$ \\
\hline Sucesso & $\begin{array}{l}\text { monitoração/métricas } \\
\text { resultados } \\
\text { retornos } \\
\text { objetivos } \\
\text { satisfação }\end{array}$ & $\begin{array}{l}\text { Obtenção dos resultados esperados face aos objetivos } \\
\text { acordados. A monitoração de indicadores de resultados deve ser } \\
\text { partilhada e o sucesso conhecido por todos de forma a } \\
\text { incentivar e recompensar o espírito de colaboração, aumentar a } \\
\text { confiança e o comprometimento, realimentando o processo. }\end{array}$ \\
\hline
\end{tabular}

Fonte: CARONA, 2004. 
O fato constatado de que as pesquisas de Mohr e Spekman (1994) - amostragem entre fabricante e distribuidor, e Monczka et al (1998b) - entre fornecedor e fabricante, apresentaram resultados semelhantes e consistentes sugere que o modelo proposto pode ser usado para estabelecer relacionamentos melhores por toda a cadeia de suprimentos. Além disso, o modelo pode ser aplicado a diferentes tipos de empresas já que foi testado em diversos ramos industriais nas pesquisas acima citadas.

Portanto, este trabalho utilizará como referência o modelo proposto por estes autores para efetuar um estudo de caso em uma indústria aeronáutica brasileira e avaliar a presença daquelas características nos relacionamentos de parceria mantidos com um grupo de fornecedores.

O modelo a ser utilizado neste trabalho é mostrado na figura 4 e incorpora três categorias de características comportamentais básicas que são determinantes do sucesso de relacionamentos colaborativos entre fabricante e fornecedor: atributos da parceria, comportamento na comunicação e técnicas de resolução de conflitos, as quais são apresentadas conceitualmente nos próximos tópicos.

\subsection{Atributos da parceria}

A importância de uma abordagem diferenciada na gestão de relacionamentos de parceria entre comprador e fornecedor está presente na literatura pesquisada, a qual relaciona comprometimento, confiança, cooperação e interdependência como atributos relevantes (DWYER et al, 1987; ANDERSON; NARUS, 1990; MOHR; SPEKMAN, 1994; WILSON, 1995; MONCZKA et al, 1998b).

Estes atributos da parceria são elementos básicos para estabelecer e manter relacionamentos colaborativos e duradouros e a existência desses elementos atua como redutor da possibilidade de comportamentos oportunistas (MOHR; SPEKMAN, 1994).

Uma revisão mais detalhada da literatura sobre estes quatro atributos é apresentada a seguir. 


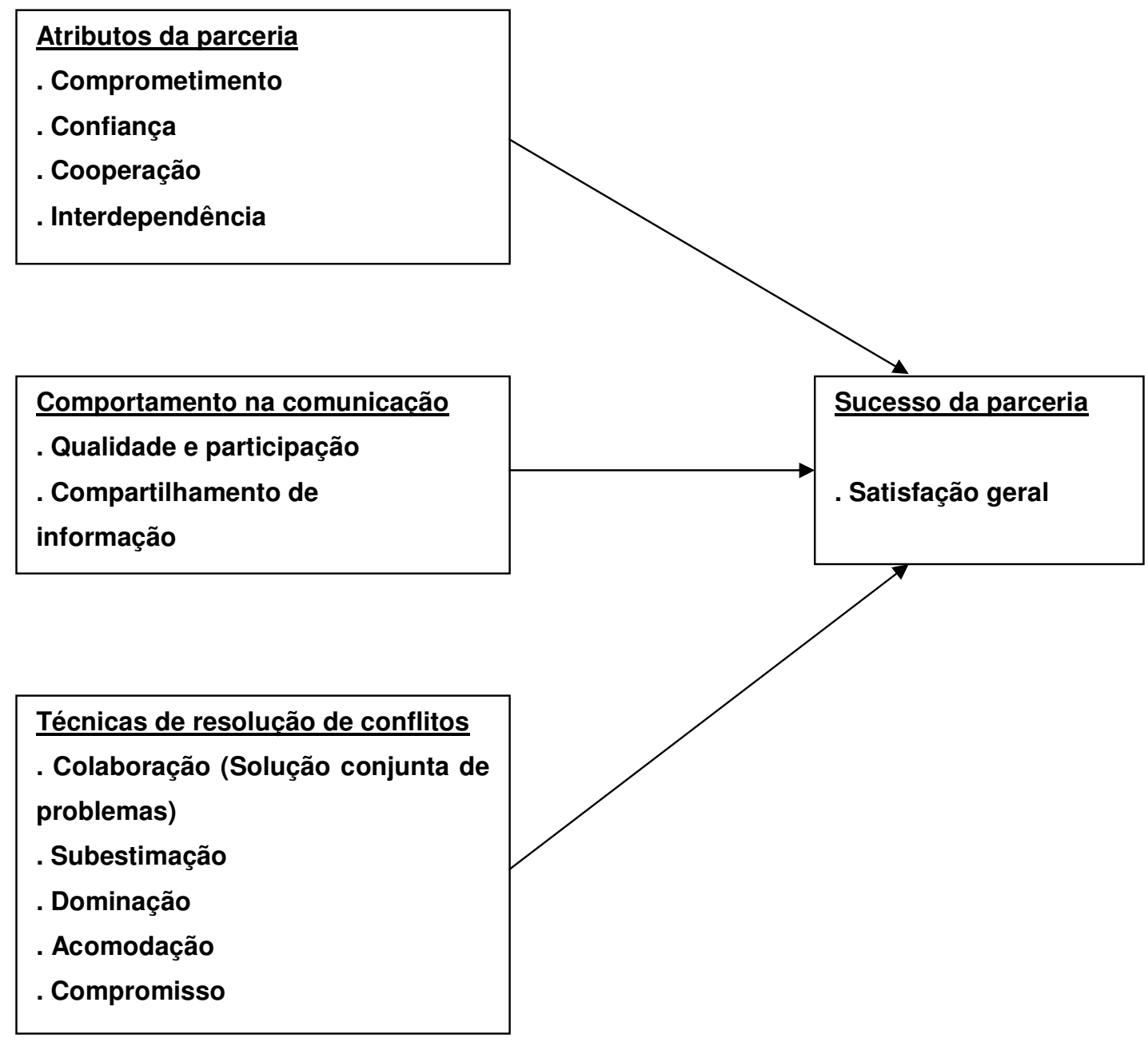

Figura 4 - Modelo conceitual - Fatores de sucesso Fonte: MOHR; SPEKMAN (1994).

\subsubsection{Confiança}

Confiança é considerada a característica mais crítica e o indicador principal de atitudes que conduzem à formação e manutenção de relacionamentos colaborativos entre comprador e fornecedor, sendo uma variável fundamental presente na maioria dos modelos de relacionamento (WILSON, 1995; MORGAN; HUNT, 1994).

Confiança é a crença de que a palavra do parceiro é confiável, que ele agirá no sentido dos melhores interesses da outra parte, cumprirá com suas obrigações, fará a sua parte no 
relacionamento e não tomará atitudes inesperadas que tragam resultados negativos (DWYER et al, 1987; MOHR; SPEKMAN, 1994; WILSON, 1995; ANDERSON; NARUS, 1990).

De acordo com Ganesan (1994), confiança deriva de duas dimensões distintas:

a) Credibilidade $=$ componente racional que indica em que extensão o comprador acredita que o fornecedor tenha o conhecimento requerido para executar o trabalho com eficácia e confiabilidade, englobando consistência, estabilidade e controle do comportamento;

b) Benevolência = componente emocional que foca em intenções e motivos, e indica em que extensão o comprador acredita que o fornecedor agirá no sentido do melhor interesse do parceiro quando surgirem condições imprevistas.

Desta forma, a confiança estará estabelecida no relacionamento comprador-fornecedor quando ambas as partes acreditarem que o parceiro tem credibilidade e age com benevolência.

Uma visão semelhante é apresentada por Gao et al (2005) que afirmam que a confiança do comprador no fornecedor é estabelecida quando o comprador acredita na disposição do fornecedor em manter suas promessas e na sua habilidade de apresentar um desempenho competente que satisfaça as necessidades, e que a confiança do comprador no fornecedor não durará a menos que haja reciprocidade da parte do fornecedor.

A literatura revela que a presença de confiança entre as partes melhora o desempenho do relacionamento em vários aspectos: mais vantagens competitivas são atingidas; os lucros conjuntos são maiores e a rentabilidade crescente; o tempo de duração do relacionamento aumenta (JAP; ANDERSON, 2003; LINDGREEN, 2003). Adicionalmente, os resultados obtidos excedem aqueles que seriam atingidos caso as empresas agissem de forma isolada e em interesse próprio (ANDERSON; NARUS, 1990).

Essa melhoria de desempenho se dá porque a confiança torna o comportamento dos parceiros menos imprevisível, reduz os custos de transação e o risco de comportamento oportunista, desenvolve uma orientação de longo prazo e encoraja a cooperação (GANESAN, 1994; GULATI, 1995; MOORE; CUNNINGHAM, 1999; JOHNSON et al, 2003; LINDGREEN, 2003). 
Por outro lado, de acordo com Roxenhall e Ghauri (2004), a falta de confiança entre as partes resulta no estabelecimento de contratos formais, os quais serão tanto mais detalhados e extensos, quanto maior for o negócio envolvido. Conseqüentemente, maiores serão os custos associados à elaboração, manutenção e gestão dos referidos contratos.

Assim sendo, confiança é vista como um fator central para o sucesso dos relacionamentos (MORGAN; HUNT, 1994; LINDGREEN, 2003) e está diretamente relacionada com altos níveis de satisfação (JOHNSON et al, 2003).

Portanto, o papel fundamental da confiança no desenvolvimento de parcerias de sucesso entre comprador e fornecedor fica caracterizado.

A presença de confiança nos estágios iniciais da construção do relacionamento compradorfornecedor resulta em comprometimento nos estágios mais avançados (DWYER et al, 1987; WILSON, 1995).

Confiança é o principal determinante do comprometimento com o relacionamento (MORGAN; HUNT, 1994), característica que será abordada detalhadamente em seguida.

\subsubsection{Comprometimento}

Assim como confiança, comprometimento tem sido considerado como um fator crucial nas pesquisas sobre relacionamentos colaborativos entre comprador e fornecedor (KRAUSE, 1999; MORGAN; HUNT, 1994).

Comprometimento significa o desejo do comprador e do fornecedor em despender esforços pelo relacionamento, desenvolver um relacionamento estável e trabalhar para garantir sua continuidade (WILSON, 1995; ANDERSON; WEITZ, 1992).

Pesquisas anteriores indicam que comprometimento representa uma orientação de longo prazo para o relacionamento, envolve uma disposição para fazer sacrifícios de curto prazo para manter o relacionamento no futuro e caracteriza a importância do relacionamento para os parceiros (DWYER et al, 1987; ANDERSON; WEITZ, 1992; WILSON, 1995). 
Comprometimento mostra uma intenção de envolvimento profundo na parceria, leva tempo para ser construído, requer investimentos e dedicação de recursos e implica assumir riscos (ANDERSON; WEITZ, 1992; KUMAR et al, 1995).

$\mathrm{Na}$ mesma linha, Monczka et al (1998b) afirmam que o comprometimento com o relacionamento é frequentemente demonstrado através do direcionamento de recursos, na forma de tempo, dinheiro e instalações, especificamente para atender a outra parte.

Alguns estudos dão suporte a estas inferências. Heide e John (1990) encontraram uma relação entre comprometimento de recursos e continuidade de relacionamentos entre empresas, enquanto Anderson e Weitz (1992) obtiveram uma forte evidência de que alto nível de investimento de recursos no relacionamento resulta em aumento do comprometimento do parceiro com o relacionamento. Esses estudos sugerem que a dedicação de recursos por ambas as partes para o desenvolvimento do relacionamento resulta em parcerias de sucesso.

Wren e Simpson (1996) sugerem que comprometimento está intimamente relacionado com satisfação e representa a continuidade do relacionamento entre comprador e fornecedor no longo prazo.

Em resumo, a revisão da literatura apresentada demonstra que comprometimento é fundamental para o sucesso de relacionamentos entre comprador e fornecedor.

Estudo empírico realizado por Hibbard et al (2001) demonstra que confiança e comprometimento têm um impacto positivo no desempenho do relacionamento.

Morgan e Hunt (1994) consideram comprometimento e confiança como os dois componentes mais importantes dos relacionamentos. Ambos os atributos são fatores-chave, pois ensejam das partes envolvidas no relacionamento atitudes como:

- Proporcionar recursos, oportunidades e benefícios superiores aos oferecidos por parceiros alternativos;

- Trabalhar para preservar o relacionamento através da cooperação;

- Manter alto padrão de valores corporativos alinhados com o parceiro;

- Compartilhar informação valiosa, incluindo expectativas, inteligência de mercado, avaliação de desempenho do parceiro; 
- Resistir a situações atrativas de curto prazo em favor de benefícios de longo prazo;

- Evitar comportamento oportunista.

Em resumo, comprometimento e confiança levam ao comportamento cooperativo que conduz ao sucesso do relacionamento.

\subsubsection{Cooperação}

Morgan e Hunt (1994) colocam a cooperação como essencial nos relacionamentos entre empresas e enfatizam o aspecto pró-ativo da cooperação em oposição à necessidade de coerção para agir de forma interdependente.

De acordo com Anderson e Narus (1990), cooperação é definida como ações coordenadas, similares ou complementares, empreendida pelas empresas participantes da parceria para atingir metas comuns e resultados mútuos ao longo do tempo.

Essa ação coordenada reflete o conjunto de tarefas que cada parte espera que a outra desempenhe, é direcionada a objetivos mútuos consistentes através das empresas e é uma marca das parcerias de sucesso (MOHR; SPEKMAN, 1994).

Wren e Simpson (1996) afirmam que cooperação refere-se à forma como os membros da cadeia de suprimentos sincronizam suas atividades para obter benefícios mútuos.

A conceituação acima mostra a importância das empresas entenderem que devem trabalhar em conjunto para obter o sucesso do relacionamento.

Pesquisas realizadas demonstram que cooperação tem forte ligação com confiança e comprometimento. O estudo de Anderson e Narus (1990) apresenta suporte à idéia de que cooperação é influenciada positivamente pela confiança existente entre os parceiros. Uma vez que a confiança é estabelecida, as empresas entendem que esforços conjuntos coordenados levam a resultados que excedem aqueles que seriam obtidos caso agissem isoladamente em seus próprios interesses. 
Wilson (1995) afirma que a interação entre comprometimento e cooperação permite que a parceria funcione adequadamente, garantindo que ambas as partes recebam os benefícios do relacionamento. Adicionalmente, Wren e Simpson (1996) postulam que altos níveis de comprometimento e cooperação são um indicativo de relacionamento eficaz.

Morgan e Hunt (1994) concluíram que confiança e comprometimento influenciam diretamente a cooperação entre empresas, e esta promove sucesso no relacionamento.

Alguns estudos apontam que cooperação entre parceiros melhora a produtividade e leva a um aumento significativo dos resultados, individuais e conjuntos, para ambas as partes (ANDERSON; NARUS, 1990; DWYER et al, 1987).

Nesse mesmo sentido, Hibbard et al (2001) entendem que desenvolver relacionamentos cooperativos, baseados em confiança e comprometimento, pode gerar benefícios significativos para as empresas participantes. Por outro lado, os resultados da pesquisa realizada por Jap (1999) mostram a cooperação entre empresas como uma fonte de vantagem competitiva.

Anderson e Narus (1990) prevêem uma relação positiva entre cooperação e satisfação. O trabalho conjunto dos parceiros na busca de resultados e benefícios mútuos constrói um forte sentimento de compatibilidade entre eles e resulta em satisfação com o relacionamento.

As evidências acima indicam que há uma relação positiva entre cooperação e satisfação, o que mostra sua importância para o sucesso de parcerias comprador-fornecedor.

\subsubsection{Interdependência}

Interdependência existe quando o controle de todas as condições necessárias para a execução de uma ação ou para atingir um resultado desejado não está inteiramente nas mãos de uma única entidade (MONCZKA et al, 1998b).

Dependência é definida como a extensão com que um parceiro traz para o relacionamento recursos importantes e críticos, para os quais existam poucas fontes alternativas de suprimento ou não hajam alternativas disponíveis no mercado que sejam equivalentes ou melhores 
(HIBBARD et al, 2001; GAO et al, 2005). Dependência está relacionada à necessidade dos parceiros em manter o relacionamento para atingir as metas desejadas (GANESAN, 1994; KUMAR et al, 1995).

Mohr e Spekman (1994) observam que quando as empresas atuam em conjunto para atingir metas que beneficiam ambas as partes, há o reconhecimento explícito de que uma torna-se dependente da outra. Quando ambas as empresas percebem benefícios mútuos advindos da parceria e entendem que a perda de autonomia será compensada de forma eqüitativa pelos ganhos esperados, então a interdependência estará presente.

Um aspecto relevante presente na literatura diz respeito ao grau de dependência.

Segundo Ganesan (1994), a dependência aumenta quando:

- Os resultados obtidos são importantes e de alto valor;

- A magnitude da troca entre as partes é alta;

- Os resultados excedem aqueles disponíveis de fontes alternativas;

- As fontes alternativas são escassas;

- A magnitude dos ativos específicos associados ao relacionamento é alta.

Nesta mesma linha de argumentação, Morgan e Hunt (1994) postulam que dependência varia diretamente com o valor recebido do parceiro e inversamente com a disponibilidade de alternativas (opções de parceiros).

De acordo com Lusch e Brown (1996), quando existe alta interdependência, há uma redução da possibilidade de comportamento oportunista e com isso, uma minimização da necessidade de contratos formais rígidos.

Adicionalmente, Bronzo (2004) afirma que, no caso de empresas parceiras, os contratos tendem a ser mais flexíveis ou apresentar um nível menor de especificações, o que reduz os custos de transação.

Outro aspecto relevante é a relação entre dependência e desempenho. 
Pesquisas demonstram que interdependência alta tem um impacto positivo na qualidade e no desempenho do relacionamento, e gera benefícios para ambas as partes (KUMAR et al, 1995; LUSCH; BROWN, 1996; HIBBARD et al, 2001). Adicionalmente, quando há uma alta interdependência entre as empresas em um relacionamento comprador-fornecedor, ambas as partes contribuirão muito mais em tempo, esforço e dinheiro aplicado para fazer o relacionamento funcionar a contento, terão forte motivação para formar parcerias de longo prazo e terão também interesse e comprometimento em garantir o sucesso do relacionamento (ANDERSON; WEITZ, 1992; LUSCH; BROWN, 1996; MENTZER et al, 2000; HIBBARD et al, 2001).

Kumar et al (1995) afirmam que confiança e comprometimento emergem sempre que a estrutura de interdependência é tal que gera convergência dos interesses dos parceiros e que esta convergência de interesses motiva os parceiros para que mantenham, reforcem e aprofundem o relacionamento através de cooperação, ação conjunta e relação ganha-ganha. Como conseqüência, os relacionamentos serão mais estáveis e propensos a desencorajar conflitos.

Portanto, há substancial evidência de que ambas as empresas envolvidas na parceria reconhecem que a interdependência gera satisfação com o relacionamento e benefícios maiores do que cada um poderia obter isoladamente.

Em suma, a literatura apresentada e citada, no que diz respeito ao construto "Atributos da parceria”, indica que parcerias bem sucedidas tendem a ser caracterizadas por níveis maiores de comprometimento, confiança, cooperação e interdependência.

\subsection{Comportamento na comunicação}

Comunicação pode ser definida como a troca formal e informal de informação relevante e no momento certo entre empresas (ANDERSON; NARUS, 1990).

A comunicação bilateral é o mecanismo para transmitir informação persuasiva, para exercer poder e para coordenar e controlar as atividades (WREN; SIMPSON, 1996). 
De acordo com Mentzer et al (2000), a coleta, criação, gestão e comunicação da informação são aspectos críticos para a eficiência, a eficácia e a vantagem competitiva da cadeia de suprimentos.

Uma estratégia de comunicação deve incluir uma combinação ótima de freqüência, direção, modalidade e conteúdo. Essa combinação favorável resulta em um fluxo contínuo de informação que beneficia ambas as partes, promove o desenvolvimento de um relacionamento de longo prazo e permite atingir os resultados esperados (WREN; SIMPSON, 1996).

Anderson e Narus (1990) afirmam que o foco está na eficácia da informação trocada e não na quantidade. Uma comunicação eficaz, aberta e em duas vias entre parceiros desempenha um papel essencial para a obtenção dos benefícios mútuos do relacionamento e é considerado um indicador chave da vitalidade da parceria (MOHR; SPEKMAN, 1994; ANDERSON; WEITZ, 1992). Adicionalmente, Lambert et al (1996) postulam que quanto mais abrangente e profunda a comunicação, mais forte torna-se a parceria.

Segundo Wren e Simpson (1996), apesar do papel central da comunicação nos relacionamentos, poucos estudos incorporam explicitamente aspectos da comunicação na relação comprador-fornecedor. No entanto, há indicações de que a comunicação afeta diretamente o nível de conflito, confiança, comprometimento e cooperação entre clientes e fornecedores (ANDERSON; NARUS, 1990; ANDERSON; WEITZ, 1992). Nesse sentido, Morgan e Hunt (1994) reforçam que comunicação gera confiança através do apoio na solução de disputas e do alinhamento de percepções e expectativas.

Lambert et al (1996) concluem que comunicação eficaz, tanto em base diária como de forma não rotineira, é um componente chave do sucesso das parcerias.

Segundo Monczka et al (1998b), os aspectos do comportamento na comunicação que indicam a amplitude da eficácia da informação para a parceria são: qualidade e participação, e compartilhamento da informação, os quais são explorados a seguir. 


\subsubsection{Compartilhamento de informação}

Compartilhamento de informação desempenha um papel fundamental na eficácia dos relacionamentos comprador-fornecedor, principalmente quanto à redução das incertezas, o que é reportado por uma vasta literatura (JOHNSON; SOHI, 2001).

Adicionalmente, Bowersox et al (2003) consideram que o compartilhamento de informação está na essência do modelo colaborativo em cadeias de suprimentos.

Compartilhamento de informação refere-se à extensão com que informação crítica e proprietária é comunicada pelos parceiros e permite a eles agirem no sentido de manter o relacionamento ao longo do tempo (MOHR; SPEKMAN, 1994). Este tipo de informação pode incluir, por exemplo, detalhes da saúde financeira, endividamento, capacidade de crescimento e estrutura de custos (MONCZKA et al, 1998).

O estudo de Lusch e Brown (1996) sugere uma associação positiva entre compartilhamento de informação entre parceiros e o desempenho do relacionamento e aponta para o fortalecimento da relação através de um fluxo aberto de informações que permite aos parceiros captarem e responderem aos objetivos de cada parte.

O alto grau de troca de informação resulta em melhores resultados, tais como: menos conflito, mais cooperação, relacionamentos mais próximos, mais confiança, maior comprometimento e maior satisfação com o relacionamento (ANDERSON; NARUS, 1990; ANDERSON; WEITZ, 1992).

Metcalf et al (1992) propuseram um modelo que explora os fatores impulsionadores de relações próximas entre comprador e fornecedor, e concluíram que a troca de informações em conjunto com contatos pessoais são condutores de uma atmosfera cooperativa. Alguns autores argumentam que troca de informações relativas a previsões de longo prazo, mercados e planejamento estrutural resulta em um maior desejo de partilhar conhecimento, o que é essencial para a cooperação entre parceiros em um relacionamento bem sucedido.

O compartilhamento de informações (boas e más) entre parceiros deve ocorrer em todos os níveis - estratégico, tático, operacional, interpessoal e cultural. A abrangência e profundidade da troca de informações nos diversos níveis estão diretamente associadas à força da parceria, 
permitem entender os benefícios associados à parceria e desenvolver vínculos nos vários níveis das empresas, contribuindo para o sucesso da parceria (LAMBERT et al, 1996; MENTZER et al, 2000). No entanto, Liker e Choi (2004) alertam que o compartilhamento de informações com os fornecedores deve ser feito de forma seletiva e estruturada, já que a obtenção de resultados depende de informações bem direcionadas e focadas.

De acordo com Mohr e Spekman (1994), o compartilhamento de informação de forma sistemática permite que as tarefas sejam executadas de forma mais eficaz, está associado a crescentes níveis de satisfação e é um importante indicador de sucesso das parcerias.

De forma geral, os estudos validam o importante papel do compartilhamento de informação no sucesso de relacionamentos comprador-fornecedor.

\subsubsection{Qualidade e participação}

Monczka et al (1998b) consideram que esses atributos da informação - qualidade e participação - estão fortemente relacionados em uma parceria e são críticos para possibilitar que ambas as partes coordenem suas atividades.

Qualidade da comunicação é um fator chave na transmissão da informação e para o sucesso da parceria, e inclui aspectos como acurácia, adequação, temporalidade, relevância e credibilidade da informação trocada, os quais são essenciais para atingir as metas da parceria (MOHR; SPEKMAN, 1994). A existência dessas dimensões é corroborada pela pesquisa de Petersen et al (2005) que afirmam que a qualidade da informação representa o grau com que a informação trocada entre as empresas atende às necessidades de ambas as organizações.

Morgan e Hunt (1994) argumentam que comunicação de alta qualidade - relevante; oportuna e fidedigna - resultará em maior confiança entre as partes, a qual é um fator central para o sucesso das parcerias.

Johnson e Sohi (2001) afirmam que quanto melhor a qualidade da informação compartilhada, menor a incerteza presente nos relacionamentos, tendo um impacto direto no desempenho global da cadeia de suprimentos em termos de redução do custo total e melhoria do nível de serviço. Um exemplo, apresentado por Moczka et al (1998b), é a geração de uma previsão 
acurada de necessidades aos fornecedores, o que permitiria um planejamento mais efetivo da parte deles quanto a disponibilizar capacidade.

Participação na informação está relacionada ao grau de ação conjunta empreendida pelos parceiros no planejamento, tomada de decisão e estabelecimento de metas. À medida que as ações de um parceiro influem na habilidade do outro de competir eficazmente, aumenta a necessidade de participação no estabelecimento de papéis, responsabilidades e expectativas (MOHR; SPEKMAN, 1994).

Planejamento conjunto pode abranger desde o compartilhamento de planos existentes até o desenvolvimento conjunto de objetivos estratégicos e quando se mostra eficaz, pode adicionar flexibilidade e força ao relacionamento, tornando-se um elemento chave de parcerias de sucesso (LAMBERT et al, 1996; LAMBERT et al, 1999).

Petersen et al (2005) apontam que muitas empresas têm buscado vantagem competitiva através da participação dos fornecedores em planejamento colaborativo.

Planejamento colaborativo pode ser entendido como o processo conjunto de tomada de decisão entre comprador e fornecedor, o qual requer maior fluxo de informação bilateral entre os parceiros e informação de alta qualidade. Como exemplo, o fornecedor informa suas restrições de capacidade produtiva enquanto o comprador informa suas necessidades de compra (PETERSEN et al, 2005).

Mohr e Spekman (1994) sugerem que a participação na tomada de decisão e na formulação de metas está associada à satisfação e ao sucesso da parceria.

O resultado da pesquisa de Petersen et al (2005) mostra um impacto positivo dos esforços de planejamento colaborativo com fornecedores no desempenho da cadeia de suprimentos. As empresas pesquisadas apresentaram uma associação positiva entre planejamento colaborativo eficaz e melhoria significativa no desempenho do fornecedor quanto à qualidade, atendimento e entrega. 
Segundo Monczka et al (1998b), os aspectos do comportamento na comunicação aqui analisados - qualidade e participação, e compartilhamento da informação - são considerados requisitos fundamentais para desenvolver parcerias de sucesso com fornecedores.

Em resumo, parcerias bem sucedidas devem exibir alto grau de qualidade da comunicação e de participação, e maior compartilhamento de informação entre os envolvidos.

\subsection{Técnicas de resolução de conflitos}

De forma ampla, Rahim (2002) define conflito como um processo interativo que se manifesta na forma de incompatibilidade, desentendimento, ou dissonância entre ou dentro de entidades sociais, tais como indivíduos, grupos, organizações, etc.

Conflito é um comportamento que impede, bloqueia ou frustra a empresa de atingir a meta perseguida (KUMAR et al, 1995; MENTZER et al, 2000;). De forma mais específica, conflito ocorre quando uma das partes percebe que a outra apresenta um comportamento que está interferindo, obstruindo ou tornando menos efetivo o esforço em atingir suas metas em um relacionamento (WEITZ; BRADFORD, 1999; DUARTE; DAVIES, 2003).

No contexto dos relacionamentos comprador-fornecedor, Anderson e Narus (1990) e Morgan e Hunt (1994) definem conflito como um nível geral de desentendimento da parceria. É a tensão percebida entre comprador e fornecedor que resulta de metas incompatíveis (JOHNSON et al, 2003).

De acordo com Duarte e Davies (2003), conflito é inerente e virtualmente inevitável em relacionamentos entre empresas, particularmente quando há interdependência entre elas. De forma similar, Weitz e Bradford (1999) e Johnson et al (2003) afirmam que devido às metas diferentes entre as duas partes, conflito é inerente nos relacionamentos comprador-fornecedor.

Diversos autores reportam que o conflito é uma questão crucial e inevitável nos relacionamentos comprador-fornecedor, e que a gestão do conflito de forma apropriada contribui para o sucesso da parceria (MOHR; SPEKMAN, 1994; MONCZKA et al, 1998; 
DUARTE; DAVIES, 2003). Nessa mesma linha, Johnson et al (2003) afirmam que o conflito pode ter um efeito negativo no relacionamento, levando a baixos níveis de satisfação, caso não seja gerenciado de forma eficaz, e até mesmo à dissolução da parceria, caso não seja resolvido.

Estudos empíricos apontam para uma relação negativa entre conflito e desempenho do relacionamento e indicam uma associação inversa entre conflito e satisfação nos relacionamentos comprador-fornecedor (ANDERSON; NARUS, 1990; DURTE; DAVIES, 2003).

Outros estudos afirmam que certo nível de conflito, quando adequadamente gerenciado, pode ter impacto positivo no desempenho da cadeia de suprimentos, pois estimula interesse e curiosidade e fornece meios para debater problemas e encontrar soluções, enquanto que a ausência total de conflito pode gerar passividade e estagnação, fazendo com que haja perda da viabilidade do relacionamento (MORGAN; HUNT, 1994; RAHIM, 2002; DUARTE; DAVIES, 2003). Weitz e Bradford (1999) apontam alguns benefícios potenciais que podem surgir de conflitos:

- Estimular o interesse em explorar novas abordagens;

- Ter a oportunidade de evidenciar problemas e explorar soluções;

- Expandir o entendimento da situação e esclarecer diferenças de perspectivas;

- Motivar adaptação e crescimento dos parceiros;

- Revitalizar as regras existentes e contribuir para o aparecimento de novas;

- Construir o comprometimento com a parceria.

Portanto, as formas como as empresas resolvem os conflitos influencia no sucesso e continuidade do relacionamento entre elas.

Uma atitude positiva dos parceiros com relação aos conflitos é um fator contribuinte para o sucesso do relacionamento (MEDINA-MUÑOZ; GARCÍA-FALCÓN, 2000). Rahim (2002) sugere o desenvolvimento de uma abordagem estratégica para minimizar as disfunções do conflito e salientar sua função construtiva como meio para melhorar o aprendizado e a eficácia na organização.

A resolução do conflito implica em sua redução, eliminação ou conclusão (RAHIM, 2002). 
A literatura mostra que o conflito pode ser administrado de diversas formas e existem alguns modelos bidimensionais sugeridos para tal, sendo que os dois modelos mais significativos são o de Thomas (WEITZ; BRADFORD, 1999) e o de Rahim e Bonoma (RAHIM, 2002).

De acordo com Weitz e Bradford (1999), o modelo de Thomas foi construído com base nas dimensões de assertividade - preocupação com seus próprios resultados, e cooperação preocupação com os resultados da outra parte, e identifica cinco abordagens para administrar o conflito:

1) Subestimação = ignorar ou evitar o conflito;

2) Acomodação = ceder aos interesses da outra parte;

3) Confrontação = impor seus próprios interesses;

4) Compromisso = fazer concessões um ao outro;

5) Colaboração = explorar soluções integrativas para satisfazer ambas as partes.

A figura 5 apresenta o modelo de Thomas com a relação entre as cinco abordagens e as dimensões respectivas.

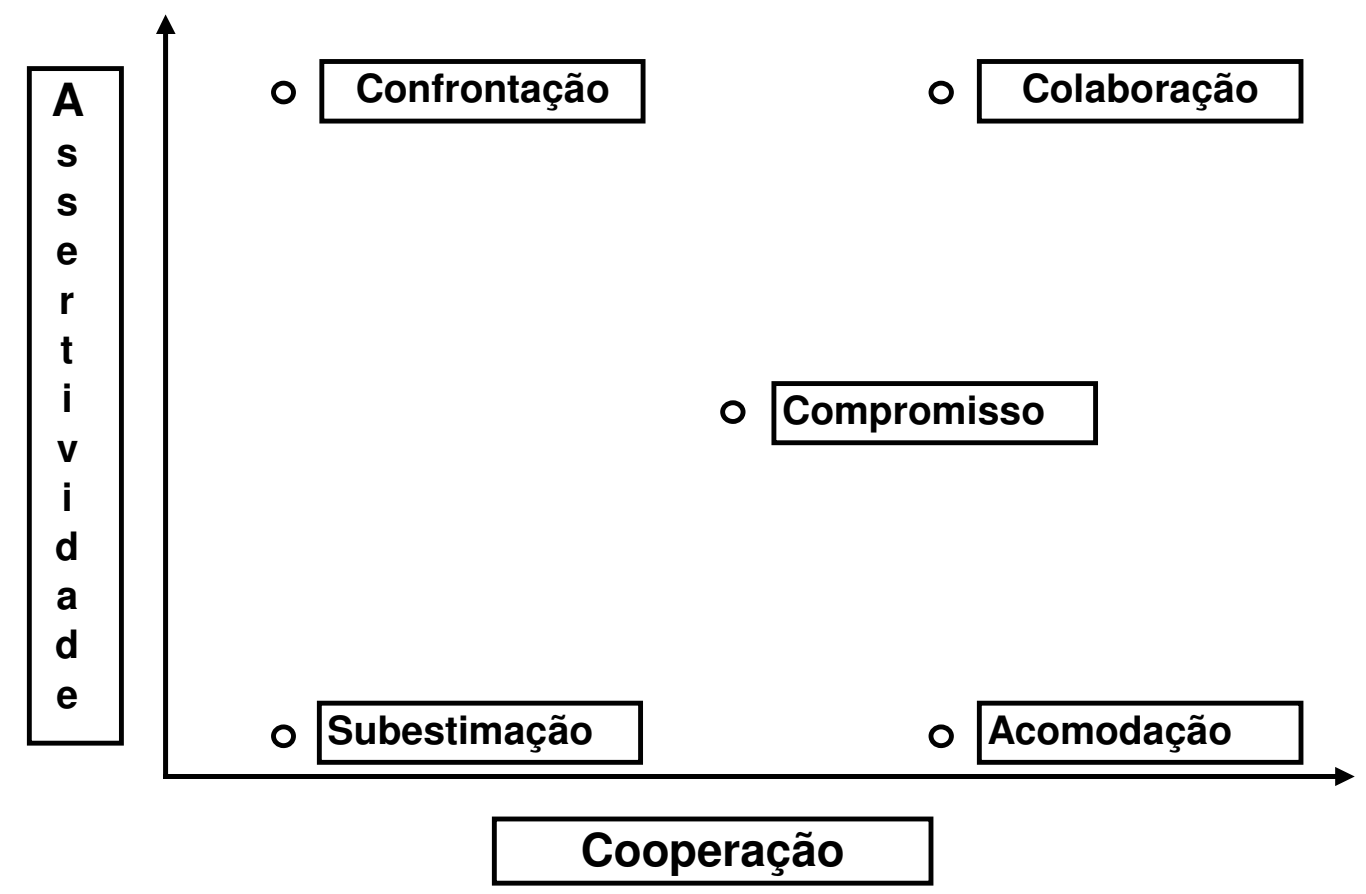

Figura 5 - Modelo de Thomas - Cinco abordagens para administrar conflitos Fonte: WEITZ; BRADFORD, 1999. 
Similar ao modelo de Thomas, o modelo de Rahim e Bonoma diferencia os estilos de gestão de conflitos em duas dimensões básicas: preocupação com si mesmo - grau com que tenta satisfazer seus próprios interesses, e preocupação com os outros - grau com que tenta satisfazer os interesses de outros (RAHIM, 2002).

Na figura 6, o modelo de Rahim e Bonoma é apresentado e também identifica cinco estilos para lidar com conflitos, os quais têm correspondência com o modelo de Thomas apresentado acima, havendo as associações de confrontação com dominação e integração com colaboração.

Com base na literatura pesquisada, este trabalho estende as abordagens propostas de administração dos conflitos para o contexto da parceria fabricante-fornecedor, incorporando ao modelo proposto, apresentado na Figura 4 do Capítulo 2, os cinco estilos de resolução de conflitos: colaboração, dominação, subestimação, acomodação e compromisso, os quais são detalhados nos tópicos a seguir.

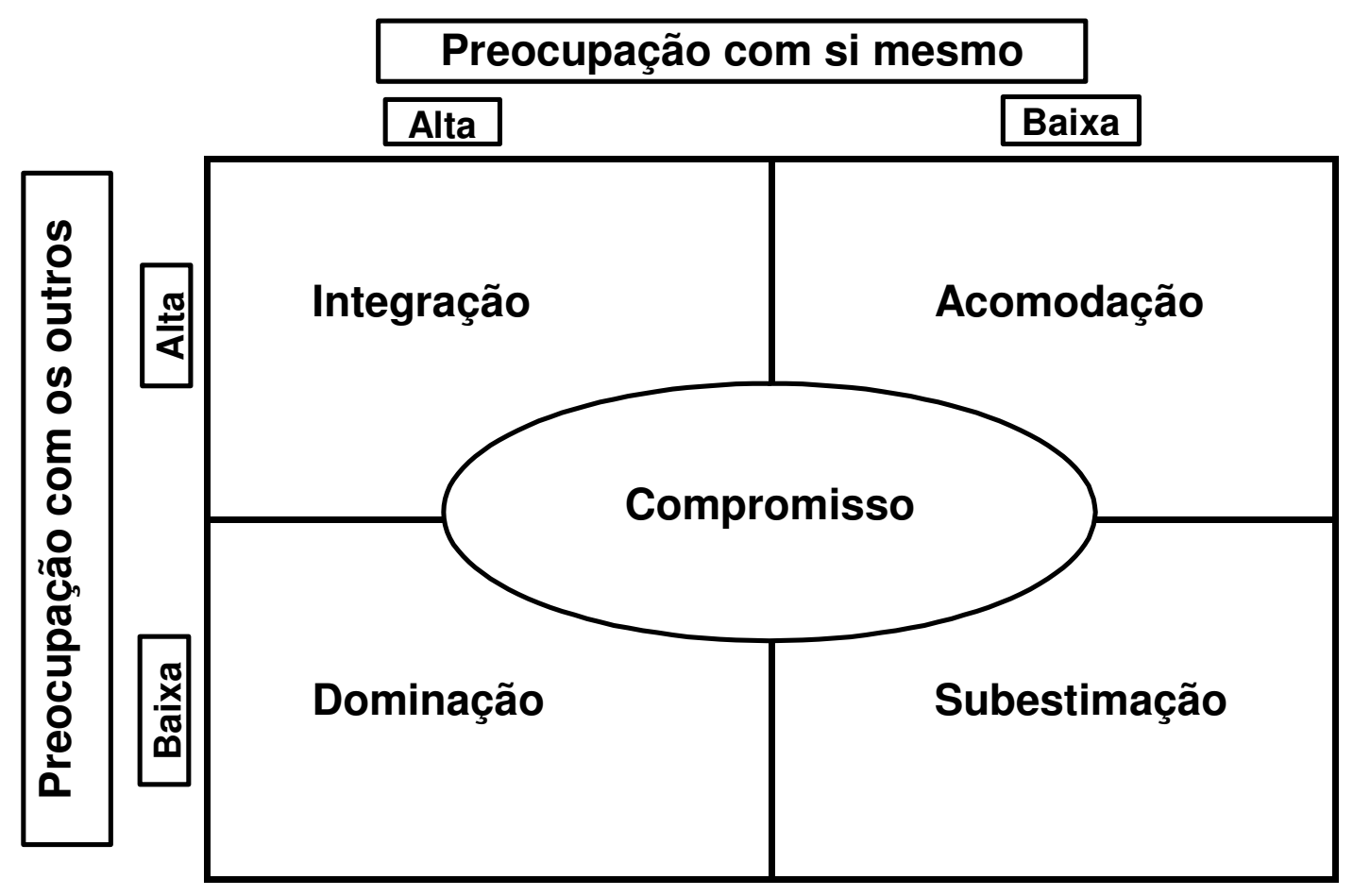

Figura 6 - Modelo de Rahim e Bonoma - Estilos de administração de conflitos Fonte: RAHIM, 2002. 


\subsubsection{Colaboração}

De acordo com Rahim (2002), o estilo integrativo (colaborativo) está associado com uma atitude de solução conjunta de problemas e o seu uso envolve abertura, compartilhamento de informação, busca por alternativas e exame das diferenças para atingir uma solução eficaz e aceitável para ambas as partes. Posto de outra forma, colaboração para resolução de conflitos requer trabalho conjunto para explorar soluções integrativas e investigar oportunidades para expandir o bolo, ou seja, achar uma solução mais ampla que atenda aos interesses de ambas as partes, criando uma situação ganha-ganha (GRAHAM, 1998; WEITZ; BRADFORD, 1999).

A solução conjunta de problemas tem maior probabilidade de obter resultados positivos, já que os esforços são direcionados para soluções integrativas e sinérgicas, as quais satisfazem melhor as necessidades de ambas as partes (MOHR; SPEKMAN, 1994; MONCZKA et al, 1998b). Esta abordagem pode ser utilizada como um meio para evitar futuros conflitos ou para propiciar discussões produtivas, contribuindo para o sucesso do relacionamento (MEDINA-MUÑOZ; GARCÍA-FALCÓN, 2000).

A abordagem colaborativa é mais eficaz que as demais, é o melhor estilo para gestão de conflitos (RAHIM, 2002) e tende a aumentar a satisfação com o relacionamento, uma vez que busca atingir resultados positivos para ambas as partes (LIN; GERMAIN, 1998).

De acordo com Weitz e Bradford (1999), o uso da abordagem colaborativa revela um sinal de comprometimento, em função da troca de informação sensível, que propicia identificar alternativas mutuamente benéficas para o conflito. Esta abordagem requer um investimento considerável de tempo e recursos humanos e, portanto, o retorno que justifica este investimento não pode ser obtido em relacionamentos descompromissados.

Em resumo, a abordagem colaborativa resolve o conflito entre as partes de forma construtiva, endereça os interesses e preocupações do comprador e do fornecedor, sem sacrificar algo de significativo, é um mecanismo poderoso de melhoria do desempenho e do relacionamento, contribui para a satisfação dos parceiros com o relacionamento e está associado positivamente com o sucesso da parceria (MOHR; SPEKMAN, 1994; MONCZKA et al, 1998b; LIN; GERMAIN, 1998; GRAHAM, 1998; WEITZ; BRADFORD, 1999). 


\subsubsection{Dominação}

Este estilo de gestão de conflitos tem sido identificado com uma orientação ganha-perde, na qual uma parte atua para satisfazer seus próprios interesses e, como resultado, ignora as necessidades e expectativas da outra parte (RAHIM, 2002).

Lin e Germain (1998) apontam que esta abordagem está relacionada a tentativas unilaterais de dominar a tomada de decisão através de pressão sobre a outra parte, com base em uma posição de desequilíbrio de forças ou de conhecimento (técnico ou gerencial).

Dominação é uma forma de ação coerciva de uma empresa sobre a outra que tende a exacerbar as diferenças existentes entre as partes. Mesmo quando aplicada com aparente sucesso, serve como solução de curto prazo, mas não endereça as questões de longo prazo que podem afetar negativamente o relacionamento (MOHR; SPEKMAN, 1994; GRAHAM, 1998).

Dominação é considerada uma técnica destrutiva de resolução de conflitos, sendo vista como contraproducente e capaz de desgastar e deteriorar o relacionamento (MOHR; SPEKMAN, 1994; MONCZKA et al, 1998b).

A pesquisa realizada por Lin e Germain (1998) aponta que a resolução de conflitos por meio da abordagem de dominação está inversamente relacionada com a satisfação com o relacionamento. Este resultado foi corroborado pelo estudo de Medina-Muñoz e GarcíaFalcón (2000) que obteve uma associação negativa significativa entre dominação e sucesso do relacionamento.

\subsubsection{Subestimação}

Esta abordagem está associada a comportamentos em que as partes ignoram o reconhecimento do desentendimento, agem como se o conflito não existisse, recusam a tomar uma posição ou deixam o destino solucionar o problema e, portanto, falha em satisfazer os interesses e preocupações de ambas as partes (WEITZ; BRADFORD, 1999; RAHIM, 2002).

Segundo Mohr e Spekman (1994), esta técnica não está alinhada com a visão pró-ativa existente em uma parceria e tende a minar sua meta de ganhos mútuos. 
A subestimação envolve um nível mínimo de comunicação e troca de informações entre as partes, resultando em falta de clareza e direção, o que aumenta o nível de conflito e tem um efeito negativo sobre o relacionamento (WEITZ; BRADFORD, 1999). Adicionalmente, Mohr e Spekman (1994) afirmam que esta abordagem pouco contribui para evidenciar os problemas associados ao conflito e falha em descobrir a sua causa raiz, e como consequiência, pode resultar em um conflito renovado e de maior escala no futuro, já que a causa do problema não foi eliminada (MONCZKA et al, 1998b).

\subsubsection{Acomodação}

De acordo com Rahim (2002), esta abordagem está associada à tentativa de uma das partes em minimizar as diferenças e enfatizar os pontos comuns para satisfazer os interesses da outra parte, negligenciando seus próprios interesses. Uma das partes reconhece o conflito e cede aos interesses ou pontos de vista da outra parte (WEITZ; BRADFORD, 1999).

Weitz e Bradford (1999) afirmam que esta abordagem envolve uma troca limitada de informações, sinaliza a disposição de considerar as necessidades de uma das partes apenas e faz concessões para gerar comprometimento com o relacionamento.

A acomodação é vista como uma abordagem não construtiva, orientada para o curto prazo, não endereça as questões de longo prazo e como conseqüência, apresenta um impacto negativo sobre a parceria (MOHR; SPEKMAN, 1994; MONCZKA et al, 1998b).

\subsubsection{Compromisso}

Compromisso é definido como chegar a um bom termo, ou a um acordo por meio de concessão de ambas as partes (GRAHAM, 1998). Envolve um dar e receber pelo qual, ambos os parceiros, fazem concessões um ao outro para chegar a um acordo mutuamente aceitável (WEITZ; BRADFORD, 1999; RAHIM, 2002).

Segundo Weitz e Bradford (1999), esta abordagem envolve a troca de informações sobre metas, seguida de concessões para chegar a uma posição intermediária que satisfaça o 
comprador e o fornecedor. Está associada a discussões sobre como dividir o bolo existente, caracterizando uma situação ganha-perde.

Graham (1998) afirma que as partes em conflito, sabendo que terão que ceder em suas demandas para chegar a um acordo, inflam inicialmente suas posições e que esta abordagem não funciona porque as diferenças não foram totalmente evidenciadas e, portanto, não puderam ser realmente resolvidas. Esta abordagem gera soluções paliativas e temporárias e faz com que, cedo ou tarde, o mesmo conflito retorne ou outro maior apareça, degradando o relacionamento.

Assim, compromisso é uma abordagem que pode não ser efetiva na resolução de conflitos e pode ter um impacto negativo para a parceria.

De acordo com Weitz e Bradford (1999), as diferenças entre as abordagens de resolução de conflitos acima detalhadas podem ser sumarizadas em relação a algumas características que são associadas com o processo de evolução do relacionamento no sentido da parceria. Essas características compõem aspectos considerados críticos para a gestão de relacionamentos, tais como comunicação, cooperação, compartilhamento de informações e comprometimento. $\mathrm{O}$ Quadro 3 apresenta a relação dessas características com as abordagens de resolução de conflitos.

A revisão da literatura acima apresentada sobre os cinco estilos de resolução de conflitos mostra que cada estilo tem um impacto diferente para o relacionamento e a forma como o conflito é solucionado contribui para a satisfação e o sucesso do relacionamento compradorfornecedor. As abordagens de dominação, subestimação, acomodação e compromisso, em graus diferentes, não eliminam o conflito totalmente e quase com certeza farão com que o conflito reapareça renovado no futuro. Por outro lado, a abordagem colaborativa resolve completamente o conflito porque integra os pontos de vista do comprador e do fornecedor de forma sinérgica criando uma situação ganha-ganha.

Em suma, pode-se concluir que parcerias de sucesso estão associadas ao uso recorrente de técnicas construtivas de resolução de problemas - abordagem colaborativa, e à minimização do uso das técnicas destrutivas e paliativas - abordagens de dominação, subestimação, acomodação e compromisso. 
Quadro 3 - Características das abordagens de resolução de conflitos

\begin{tabular}{|l|c|c|c|c|c|}
\hline Característica & Subestimação & Acomodação & Dominação & Compromisso & Colaboração \\
\hline Assertividade & Baixa & Baixa & Alta & Média & Alta \\
\hline Cooperação & Baixa & Alta & Baixa & Média & Alta \\
\hline $\begin{array}{l}\text { Natureza da } \\
\text { comunicação }\end{array}$ & Não há & Mão única & Mão única & Mão dupla & Mão dupla \\
\hline $\begin{array}{l}\text { Volume de } \\
\text { informação } \\
\text { trocada sobre } \\
\text { perspectivas e } \\
\text { metas }\end{array}$ & Baixo & Baixo & Alto & Médio & Alto \\
\hline $\begin{array}{l}\text { Volume de } \\
\text { informação } \\
\text { sensível } \\
\text { compartilhada }\end{array}$ & Baixo & Baixo & Médio & Médio & Alto \\
\hline $\begin{array}{l}\text { Comprometimento } \\
\text { com o } \\
\text { relacionamento }\end{array}$ & Baixo & Médio & Baixo & Médio & Alto \\
\hline
\end{tabular}

Fonte: WEITZ; BRADFORD, 1999.

\subsection{Sucesso do relacionamento comprador-fornecedor}

A literatura sobre relacionamento comprador-fornecedor demonstra que as empresas buscam através da parceria melhorar seu desempenho e obter vantagem competitiva sustentável, o que inclui prover valor diferenciado ao cliente, aumentar participação de mercado e rentabilidade, melhorar o uso de ativos e o fluxo de caixa, reduzir custos de transação, melhorar a qualidade, reduzir preços e ciclos (ELLRAM, 1995; MOHR; SPEKMAN, 1994).

De acordo com Gulati (1998), pesquisas sobre desempenho de parcerias têm sido difíceis de conduzir devido aos obstáculos que surgem quanto à medição do desempenho de forma apropriada e consistente, e quanto aos desafios logísticos para coleta dos dados necessários.

Definir e medir o desempenho de parcerias tem se mostrado uma tarefa complexa, não havendo critério de sucesso simples e abrangente que possa ser usado de forma satisfatória (DUSSAUGE; GARRETTE, 1995). 
Em termos gerais, os estudos que examinaram a questão do desempenho das alianças utilizaram-se dos seguintes critérios de avaliação:

1) Medidas objetivas (quantitativas) - indicadores financeiros ou contábeis (por ex., crescimento das vendas, rentabilidade); evolução das ações nas bolsas de valores; estabilidade e longevidade do relacionamento; evolução de ciclos, preços e qualidade (MOHR; SPEKMAN, 1994; MONCZKA et al, 1998b; KALE et al, 2002; WREN; SIMPSON, 1996);

2) Medidas subjetivas (qualitativas) - satisfação geral com o relacionamento; extensão com que a aliança atingiu seus objetivos globais (DUSSAUGE; GARRETTE, 1995; GLAISTER; BUCKLEY, 1998; BENTON; MALONI, 2005).

Monczka et al (1998b) concluíram que é difícil interpretar os resultados de medidas objetivas sobre o sucesso da parceria.

Adicionalmente, pesquisa realizada por Lemke et al (2003) demonstrou que indicadores quantitativos como qualidade, preço e desempenho de entrega não são particularmente importantes para explicar parcerias com fornecedores, ou seja, são indiferentes quanto à forma de relacionamento existente entre as partes.

O estudo realizado por Martins e Gonçalves (2004), em uma indústria do segmento automotivo brasileiro, sobre indicadores de desempenho de fornecedores, mostra que os critérios de avaliação utilizados não incluem nenhuma diferenciação quanto ao tipo de relacionamento existente entre montadora e fornecedor.

A utilização de medidas objetivas de desempenho apresenta algumas imperfeições: ignora o fato de que muitos aspectos e benefícios dos relacionamentos colaborativos e das parcerias não podem ser quantificados; tende a dar apenas indicação temporal da eficácia do relacionamento; não sinaliza as intenções de longo prazo de cada um dos parceiros; não reflete adequadamente em que extensão a parceria atingiu suas metas iniciais (GLAISTER; BUCKLEY, 1998; WREN; SIMPSON, 1996; JAP, 1999).

Wren e Simpson (1996) afirmam que medidas quantitativas mostram resultados de curto prazo, enquanto indicadores qualitativos explicitam as intenções dos parceiros com a continuidade do relacionamento. 
No entanto, a continuidade do relacionamento não significa necessariamente que as partes façam uma avaliação positiva da parceria, já que elas podem estar contratualmente vinculadas, pode não haver desejo, tempo ou possibilidade de substituição de uma das partes, ou ainda, podem existir altos custos associados ao encerramento da parceria (GULATI, 1998; JOHNSON et al, 2003).

A discussão sobre medidas objetivas e subjetivas de desempenho reflete a crescente preocupação sobre a forma mais apropriada de avaliar a eficácia dos relacionamentos e mostra a necessidade de ir além das medidas unidimensionais, tais como dados quantitativos de desempenho (WREN; SIMPSON, 1996).

Essa preocupação quanto à capacidade das medidas objetivas de efetivamente capturar o desempenho da aliança tem levado diversos pesquisadores a utilizar medidas subjetivas da satisfação do parceiro com o desempenho da aliança (GLAISTER; BUCKLEY, 1998; DUSSAUGE; GARRETTE, 1995).

Esta escolha tem sido suportada por pesquisas que mostram que medidas objetivas são positivamente correlacionadas com medidas subjetivas de desempenho (DUSSAUGE; GARRETTE, 1995; KALE et al, 2002).

Mais especificamente, Glaister e Buckley (1998) afirmam que medidas objetivas têm correlação positiva com a satisfação geral com o desempenho reportada por empresas parceiras.

\subsubsection{Satisfação geral}

Alguns autores afirmam que a satisfação geral é uma variável de fundamental importância na construção e na compreensão dos relacionamentos em cadeias de suprimentos e tem relação direta com aumento de produtividade, redução de conflitos e aumento de eficiência da cadeia como um todo (LEE, 2001; JOHNSON et al, 2003). 
Anderson e Narus (1990) colocam a satisfação como uma conseqüência focal do relacionamento comprador-fornecedor e a consideram como uma variável chave para prever a continuidade de relacionamentos no longo prazo.

Satisfação é definida como uma avaliação global do relacionamento entre dois membros da cadeia de suprimentos e indica uma intenção subjetiva dos parceiros em manter o relacionamento bilateral (LEE, 2001; ANDERSON; NARUS, 1990). Reflete um estado afetivo positivo, um sentimento de contentamento e igualdade com o relacionamento (GANESAN, 1994; BENTON; MALONI, 2005).

De acordo com Ganesan (1994), pesquisas indicam que a satisfação contribui para aumentar a moral e a cooperação entre membros da cadeia de suprimentos, e para reduzir conflitos.

A avaliação de desempenho através de indicadores qualitativos, como a satisfação geral, tem sido realizada com base nas opiniões de gerentes (KALE et al, 2002).

Tem havido um crescente consenso entre acadêmicos que, se adequadamente executada, a avaliação gerencial é uma forma razoável de medir o desempenho de relacionamentos de parceria (DUSSAUGE; GARRETTE, 1995; KALE et al, 2002).

Em resumo, satisfação geral, um indicador subjetivo de desempenho do relacionamento comprador-fornecedor obtido através de avaliação gerencial, pode ser considerada uma medida adequada para avaliar o sucesso da parceria.

Este capítulo explorou os construtos relacionados ao sucesso de parcerias entre agentes em cadeias de suprimentos. Apresentou um modelo teórico já testado empiricamente em estudos anteriores, o qual contempla características que são consideradas determinantes do sucesso de parcerias - atributos da parceria, comportamento na comunicação e técnicas de resolução de conflitos. O capítulo termina discutindo a satisfação geral - uma medida subjetiva, como sendo uma forma adequada de mensurar o sucesso da parceria fabricante-fornecedor neste trabalho.

O próximo capítulo apresenta a metodologia adotada na presente pesquisa. 


\section{METODOLOGIA DA PESQUISA}

Este capítulo inicia mostrando a crescente importância da pesquisa empírica na área de gestão de operações. Em seguida, apresenta a estratégia de pesquisa adotada - estudo de caso, e as proposições deste trabalho. O capítulo discute a unidade de análise, os instrumentos utilizados para a coleta de dados, as fontes de informação e os elementos de mensuração dos construtos apresentados no capítulo anterior. Para finalizar, são apresentados os procedimentos utilizados para a análise dos dados e das informações coletadas.

\subsection{Conceituação básica}

O progresso científico é produto da atividade humana e o homem, para evoluir e fazer evoluir o meio em que vive, utiliza-se de diversas formas de conhecimento: filosófico, teológico, empírico e científico. O conhecimento científico resulta da pesquisa metodológica e sistemática do contexto factual e está constantemente se renovando diante da nossa necessidade de compreender, dominar e ser capaz de transformar o meio em que vivemos (FACHIN, 2005).

De acordo com Ramsay (1998), metodologia diz respeito ao estudo dos meios para obter conhecimento sobre o mundo, ou seja, trata da análise de como a pesquisa deve ser executada. Desta análise chega-se ao método, procedimento sistemático e ordenado que permita identificar a forma como alcançamos determinado objetivo ou a natureza de um determinado problema (OLIVEIRA, 2002).

$\mathrm{Na}$ área de gestão de operações, a pesquisa empírica ou pesquisa de campo - aquela em que os dados são coletados no contexto do negócio ou do ambiente social no qual a prática ocorre, tem ganhado crescente importância ao longo do tempo, em oposição aos métodos tradicionais envolvendo modelagem, simulação ou otimização (MALHOTRA; GROVER, 1998; RUNGTUSANATHAM et al, 2003). Os trabalhos destes autores constataram que esse progresso no uso da pesquisa empírica é evidenciado não apenas pela quantidade, mas também pela qualidade e sofisticação apresentados. 
Flynn et al (1990) já postulavam a necessidade de uma maior utilização de pesquisa empírica em gestão de operações, como forma de documentar o estado da arte das práticas empresariais, de prover base de referência para estudos longitudinais, de desenvolver parâmetros para os estudos de modelagem e simulação, e de verificar e desenvolver teoria.

Este trabalho caracteriza-se por ser uma pesquisa de campo e adota, em sua estrutura geral, a abordagem sugerida por Flynn et al (1990), a qual é oriunda das ciências sociais, e é mostrada na Figura 7.

Nos tópicos que seguem são detalhados os componentes desta pesquisa.

\subsection{Tipificação da pesquisa}

O ponto de partida deste trabalho foi a revisão teórica sobre os temas relevantes relacionados ao objeto de estudo: gestão de cadeia de suprimentos, gestão de relacionamentos entre empresas e fatores indutores de parceiras bem sucedidas. Esta revisão permitiu contextualizar o objeto de estudo, definir suas fronteiras e obter os parâmetros a serem considerados no levantamento de dados, com o objetivo de verificar a respectiva teoria.

O passo seguinte foi a análise das estratégias de pesquisa disponíveis e a escolha daquela que fosse mais adequada para atingir o objetivo pretendido por este trabalho.

De acordo com Yin (1994), existem várias formas de fazer pesquisa em ciências sociais. Cada estratégia tem vantagens e desvantagens, dependendo de três condições:
a) O tipo de pergunta de pesquisa;
b) $\mathrm{O}$ controle que o pesquisador tem sobre o comportamento real dos eventos;
c) O foco em fenômeno contemporâneo ou no histórico.

O Quadro 4 apresenta a relação entre as diversas estratégias de pesquisa e as condições relevantes para sua escolha. 


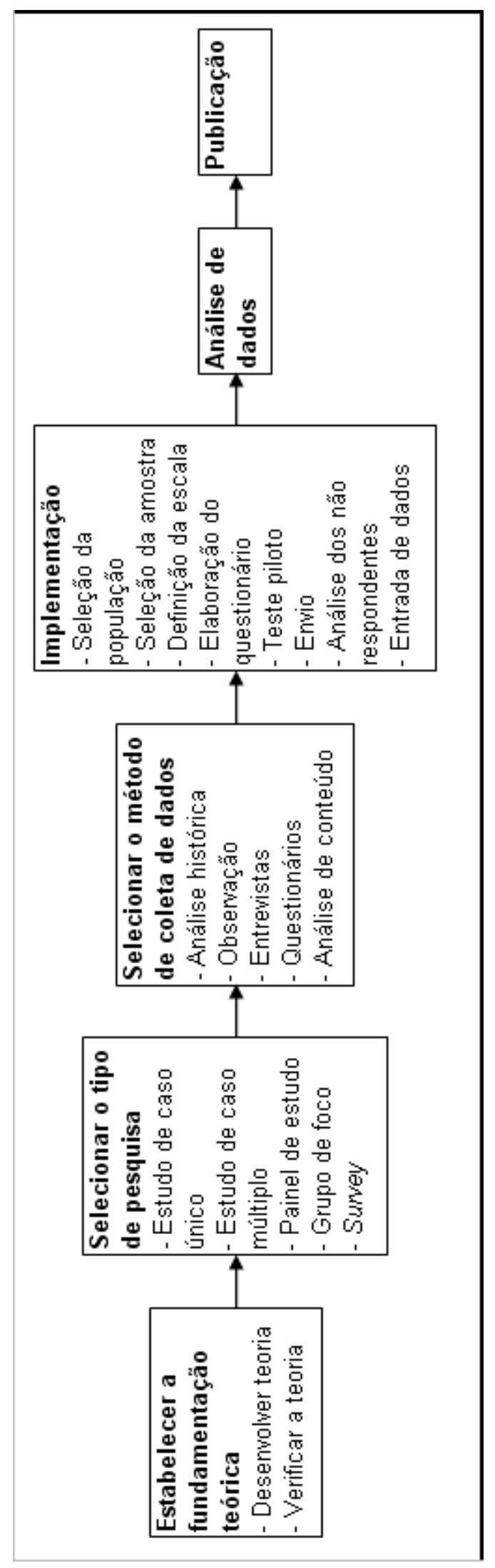

Figura 7 - Uma abordagem sistemática para pesquisa empírica Fonte: FLYNN et al, 1990 
Quadro 4 - Condições relevantes para diferentes estratégias de pesquisa

\begin{tabular}{|c|c|c|c|}
\hline Estratégia & $\begin{array}{c}\text { Forma da pergunta } \\
\text { de pesquisa }\end{array}$ & $\begin{array}{c}\text { Requer controle } \\
\text { sobre eventos } \\
\text { comportamentais? }\end{array}$ & $\begin{array}{c}\text { Focado em eventos } \\
\text { contemporâneos? }\end{array}$ \\
\hline Experimento & como; por que & Sim & Sim \\
\hline Levantamento & $\begin{array}{c}\text { quem; o que; onde; } \\
\text { quantos; quanto }\end{array}$ & Não & Sim / Não \\
\hline Análise de arquivos & $\begin{array}{c}\text { quem; o que; onde; } \\
\text { quantos; quanto }\end{array}$ & Não & Não \\
\hline Pesquisa histórica & como; por que & Não & Sim \\
\hline Estudo de caso & como; por que & Não & \\
\hline
\end{tabular}

Fonte: YIN, 1994.

Este trabalho busca analisar a presença de algumas características relevantes consideradas indutoras do sucesso de parcerias entre fabricante e fornecedor em cadeias de suprimentos, conforme exposto no capítulo 2, em um contexto específico e delimitado da prática empresarial - um projeto desenvolvido por uma indústria aeronáutica brasileira.

Portanto, o estudo de caso foi escolhido como sendo a estratégia de pesquisa mais adequada.

Segundo Stake (1995), caso é um sistema integrado, delimitado, específico, complexo e funcional. Quando temos uma necessidade de entendimento geral de uma situação, o estudo de caso é um instrumental apropriado para obter insights sobre a questão em pauta.

O estudo de caso é uma descrição analítica de um evento ou situação, para compreensão do assunto investigado (FACHIN, 2005).

Adicionalmente, Eisenhardt (1989) afirma que o estudo de caso é uma estratégia de pesquisa cujo foco é a compreensão das dinâmicas que estão presentes em ambientes únicos.

Considerando as condições relevantes para escolha da estratégia de pesquisa, Yin (1994) conclui que estudo de caso tem uma vantagem distinta como estratégia de pesquisa quando perguntas "como" ou "por que" são feitas sobre um conjunto de eventos contemporâneos, dentro de um contexto de vida real, sobre os quais o investigador tem pouco ou nenhum controle. 
O critério inicial para selecionar um caso é maximizar o que queremos aprender, ou seja, definidos os nossos objetivos, quais casos mais provavelmente nos levarão ao entendimento, afirmações ou mesmo generalizações. Outro critério poderá ser o tempo disponível e a limitação de acesso para o trabalho de campo e, portanto, a escolha pode-se dar a casos que sejam de fácil acesso e que haja receptividade por parte dos envolvidos (STAKE, 1995).

Para este trabalho, a escolha do caso deu-se pelo critério de limitação de acesso, já que no segmento da indústria aeronáutica, foco deste estudo, o número de empresas fabricantes de aeronaves é pequeno, tendo uma única empresa no Brasil. Pode ser considerada também a conveniência, facilidade de acesso e boa receptividade por parte dos envolvidos, já que este autor exerce função de liderança na empresa selecionada, com relacionamento profissional direto com as pessoas chave que serão utilizadas para obtenção das informações.

Estudos de caso tipicamente combinam métodos de coleta de dados, tais como: revisão documental e de arquivos, entrevistas, questionários e observações, e as evidências podem ser qualitativas, quantitativas ou ambas (EISENHARDT, 1989; STAKE, 1995).

Segundo Eisenhardt (1989), o estudo de caso pode ter como objetivos: descrever, testar e/ou desenvolver uma teoria.

A utilização do estudo de caso único em associação com levantamento de dados através de questionários ou com outros instrumentos de pesquisa permite desenvolver uma compreensão mais abrangente do fenômeno observado (FLYNN et al, 1990).

O objetivo deste trabalho é, fundamentalmente, descrever e desenvolver a teoria através do modelo apresentado na Figura 4, no capítulo 2. Busca captar a essência do fenômeno estudado no momento da coleta de dados e obter uma explicação válida para o mesmo.

Para tanto, utilizará evidências qualitativas obtidas por meio de questionários e entrevistas aplicados aos informantes-chaves da empresa em questão, no período compreendido entre julho e setembro de 2006.

Em resumo, a presente pesquisa é descritiva e exploratória, de corte transversal, apóia-se em um estudo de caso, tendo como referência a fundamentação teórica desenvolvida no Capítulo 
2, a qual busca verificar, e utiliza-se de análise qualitativa de dados para a interpretação e apresentação dos resultados.

\subsection{Coleta de dados}

Logo no princípio da estruturação da pesquisa, deve estar claramente definida a unidade de análise - quem ou o que está sendo estudado (RUNGTUSANATHAM et al, 2003). O instrumento de pesquisa deve coletar informação de uma unidade de análise consistente, seja ele um indivíduo, um grupo de trabalho, um projeto, uma função ou uma empresa (MALHOTRA; GROVER, 1998).

A unidade de análise deste trabalho refere-se, a nível organizacional, ao relacionamento de parceria com o fornecedor, sob a perspectiva do fabricante - uma indústria aeronáutica.

A coleta de dados, feita através de entrevistas e questionários, deve utilizar as pessoas mais apropriadas dentro da unidade de análise. Segundo Malhotra e Grover (1998), os indivíduos escolhidos devem pertencer a um nível hierárquico adequado na organização para evitar a introdução de viés relativo à função exercida, considerando o tema abordado.

Desta forma, a abordagem do informante-chave foi empregada neste trabalho.

Esta abordagem significa coletar dados de indivíduos selecionados na unidade de análise, os quais devem ser as pessoas mais versadas no tema a ser abordado, pois o conteúdo do questionário requer conhecimento específico e completo dos respondentes, bem como capacidade e disposição para se comunicar sobre o assunto com o pesquisador (KUMAR et al, 1993; MALHOTRA; GROVER, 1998).

Especificamente, nesta pesquisa, os informantes-chaves são gerentes de suprimentos, responsáveis na empresa pela seleção, avaliação, desenvolvimento e gestão de fornecedores. 


\subsubsection{Instrumento de coleta de informações}

Este questionário foi elaborado de forma não estruturada, ou seja, composto por perguntas abertas que permitem resposta livre, o que possibilita ao respondente expressar atitudes e opiniões gerais sobre o tema abordado (MALHOTRA, 2001). Este instrumento tinha o objetivo de coletar informações que caracterizassem os aspectos gerais da parceria do fabricante com os fornecedores.

O instrumento de pesquisa encaminhado aos respondentes consta do Apêndice 1 e as perguntas elaboradas são explicitadas a seguir:

1) Como você define "parceria" no contexto do programa 0170/0190?

2) Qual a abrangência dessa parceria? (Pesquisa, Tecnologia, Desenvolvimento de produto, Projeto, Finanças, Planejamento colaborativo, outros).

3) Quais os objetivos desta parceria?

4) Quais os fatores/critérios utilizados na escolha dos parceiros do programa 0170/0190?

5) Existiam metas estratégicas e/ou quantitativas? Quais?

6) Como medir os resultados alcançados e avaliar se a parceria foi bem sucedida?

7) O que diferencia "parceiro" de "fornecedor" neste contexto? (aspectos financeiros, aspectos contratuais, nível de comunicação, atributos do relacionamento).

8) Quais as similaridades e diferenças com a "parceria" do programa 0145 ?

Os informantes-chaves abordados foram os Gerentes de Suprimentos de nível sênior, os quais participaram na definição das estratégias e nas negociações para a constituição das parcerias da empresa com os fornecedores que são objetos de estudo deste trabalho.

A estrutura organizacional, na qual estão inseridos esses executivos, é apresentada no capítulo seguinte.

O questionário foi utilizado como fonte de referência para entrevistas realizadas com os Gerentes acima. As entrevistas foram agendadas através de contato prévio, no qual foram esclarecidos o objetivo pretendido e os temas a serem abordados, e foi obtida a disposição e a disponibilidade de participação. 


\subsubsection{Instrumento de coleta de dados}

Com o objetivo de obter subsídios para verificar se as características e relações componentes do modelo apresentado no capítulo anterior estão presentes no caso em estudo, foi elaborado um instrumento de pesquisa que utilizou questões múltiplas para medir os construtos do referido modelo.

De acordo com Hensley (1999), construtos são idéias complexas e multifacetadas, difíceis de serem mensuradas diretamente e através de uma escala simples.

Este instrumento de pesquisa foi elaborado de forma estruturada, ou seja, com a especificação das respostas alternativas e do formato das respostas, e utilizando uma escala de classificação de forma a que o respondente escolha a categoria que melhor descreva o objeto que está sendo analisado (MALHOTRA, 2001).

A elaboração de um questionário deve levar em consideração os seguintes aspectos destacados por Hensley (1999):

- Extensão do questionário = além do número de construtos, deve-se considerar o mínimo de itens possível para mensurar cada um deles, mas mantendo-se pelo menos três;

- Número de pontos da escala Likert = a confiabilidade cresce à medida que se chega a cinco pontos, não tendo aumento significativo acima disso;

- Uso de escala reversa = não há consenso entre os pesquisadores, sendo que alguns afirmam que seu uso reduz a tendenciosidade das respostas, enquanto outros contrapõem que reduz a validade e aumenta a possibilidade de erro sistemático;

- Alocação dos itens no questionário = não há consenso também entre os pesquisadores, com alguns afirmando que a distribuição aleatória dos itens confere maior validade e outros alegando que a seqüência lógica propicia maior facilidade para os respondentes.

O instrumento de pesquisa deste trabalho foi dividido em seis partes, sendo a primeira utilizada para caracterização dos respondentes, as quatro seguintes para mensurar cada conjunto de construtos formador do modelo referencial - atributos da parceria, comportamento na comunicação, técnicas de resolução de conflitos e sucesso da parceria, e a parte final para comentários livres dos respondentes. 
A introdução do instrumento de pesquisa informa, de forma resumida, o objetivo da pesquisa, indica como preencher o questionário e assegura aos respondentes a confidencialidade dos dados coletados e a não explicitação dos envolvidos (FREITAS et al, 2000). Adicionalmente, esta introdução orienta os informantes-chaves a responder a cada item sob a ótica do relacionamento da empresa com o fornecedor pelo qual é responsável, considerando o contexto específico do projeto que foi desenvolvido através do modelo de parceria.

Na elaboração do questionário optou-se por não utilizar escala reversa e por alocar os itens de forma aleatória dentro de cada conjunto de construtos, tendo sido utilizado cinco itens para mensurar cada um dos construtos.

O instrumento de pesquisa deste trabalho utiliza uma escala Likert de cinco pontos, com um intervalo variando de discorda totalmente (1) até concorda totalmente (5), como forma de avaliar o grau de concordância ou discordância do respondente com as afirmações sobre o tema tratado (MALHOTRA, 2001).

O instrumento utilizado é auto-administrável, o que significa que o informante responde de acordo com sua disponibilidade de tempo e sem a presença do pesquisador.

Os informantes-chaves abordados foram os Gerentes de Suprimentos responsáveis pela gestão comercial e pela administração do relacionamento com os fornecedores pertencentes ao grupo com o qual o fabricante considera que tenha estabelecido uma de parceria. A atuação desses gerentes abrange todos os aspectos da interação entre o fabricante e o fornecedor, de forma regular, contemplando o relacionamento pessoal com os diversos níveis hierárquicos e com variados setores organizacionais de ambas as empresas, a gestão dos contratos formais estabelecidos entre as empresas e a ação como elo entre as partes, tendo, portanto, amplo conhecimento e perspectiva do relacionamento entre as empresas.

O posicionamento destes gerentes, no contexto da estrutura organizacional da empresa estudada, é apresentado no próximo capítulo.

O processo utilizado para distribuição do instrumento de pesquisa foi o encaminhamento através de e-mail, após contato prévio, no qual foi esclarecido o objetivo pretendido e foi obtida a disposição de participação. Foi estabelecido de comum acordo o prazo adequado para 
retorno, de forma a assegurar que o mesmo fosse preenchido em um período conveniente para o informante e para o pesquisador, e também negociada a disponibilidade para uma entrevista posterior complementar, em caso de necessidade de esclarecimentos e informações adicionais.

Os itens utilizados para mensuração dos construtos tiveram seus enunciados baseados na revisão da literatura e foram adaptados de pesquisas realizadas anteriormente que abordaram cada uma das características componentes do modelo referencial apresentado no capítulo anterior. Os itens, seus enunciados e as respectivas pesquisas utilizadas como referência são apresentados a seguir.

\subsubsection{Confiança}

As assertivas deste atributo foram adaptadas da pesquisa de Moore e Cunningham (1999) sobre alianças logísticas que foi baseada nos trabalhos de Morgan e Hunt (1994) e Ganesan (1994) e são as seguintes:

1. Posso contar com este fornecedor para fazer o que é certo.

2. Este fornecedor tem um alto grau de integridade.

3. Este fornecedor cumpre com suas promessas.

4. Este fornecedor é honesto quanto aos problemas quando estes surgem.

5. Este fornecedor não faz reivindicações infundadas.

\subsubsection{Comprometimento}

Para este atributo, foi adaptado o trabalho de Krause (1999) que estudou os fatores relevantes no contexto do desenvolvimento de fornecedores e foi baseado em pesquisa anterior de Anderson e Weitz (1992), sendo utilizados os seguintes itens:

1. Este fornecedor tem um forte senso de lealdade para conosco.

2. Este fornecedor mostra-se disposto a fazer investimento de longo prazo para dar suporte a nós.

3. Este fornecedor considera nosso relacionamento como uma parceria de longo prazo.

4. Este fornecedor mostra-se disposto a dedicar pessoas e recursos necessários para nos tornar clientes satisfeitos.

5. Este fornecedor não dará preferência a outro cliente em detrimento de nossa empresa. 


\subsubsection{Cooperação}

A avaliação de Johnson e Sohi (2001) para a cooperação entre empresas, baseada nas pesquisas anteriores de Anderson e Narus (1990) e Morgan e Hunt (1994), foi adaptada para este estudo através das afirmações abaixo:

1. Nós procuramos cooperar com este fornecedor de diversas formas.

2. Quando surge algum problema, tentamos resolvê-lo em conjunto.

3. Nós ajudamos este fornecedor de diversas formas, quando solicitado por ele.

4. Nós planejamos, com freqüência, atividades ou programas conjuntos com este fornecedor.

5. Este fornecedor nos ajuda de diversas formas quando solicitamos.

\subsubsection{Interdependência}

Este atributo foi adaptado da pesquisa sobre dependência entre fabricantes e distribuidores realizada por Lusch e Brown (1996), referenciada aos estudos de Ganesan (1994) e Kumar et al (1995). Os itens utilizados no presente estudo foram os seguintes:

1. Nós somos dependentes deste fornecedor.

2. Seria difícil substituir este fornecedor.

3. Teríamos um alto custo no caso de perder este fornecedor.

4. Este fornecedor é dependente de nós.

5. Este fornecedor teria um alto custo se nos perdesse.

\subsubsection{Compartilhamento de informação}

A pesquisa de Mohr e Spekman (1994) sobre parceria entre fabricante e distribuidor foi a referência para as assertivas relativas a este atributo, as quais são apresentadas abaixo:

1. Este fornecedor compartilha informação relevante conosco.

2. Nós informamos o fornecedor das mudanças necessárias com antecedência.

3. Qualquer informação que pode ajudar a outra parte espera-se que seja partilhada.

4. É esperado que cada parceiro mantenha o outro informado sobre eventos e mudanças que possam afetar a outra parte.

5. Nós partilhamos informação relevante com este fornecedor. 


\subsubsection{Participação e qualidade na informação}

As afirmações para este atributo foram adaptadas da pesquisa de Monczka et al (1999) sobre parceria entre fabricante e fornecedor que foi baseada no trabalho anterior de Mohr e Spekman (1994) e são as seguintes:

1. Nós buscamos ativamente aconselhamento com este fornecedor.

2. Este fornecedor participa de nossas atividades de planejamento e estabelecimento de metas que sejam relevantes para nosso relacionamento.

3. Nós encorajamos este fornecedor a dar sugestões de melhoria.

4. Nós participamos das atividades de planejamento e estabelecimento de metas deste fornecedor que sejam relevantes para nosso relacionamento.

5. Nossa comunicação com este fornecedor é adequada, acurada, crível, oportuna e completa.

\subsubsection{Técnicas de resolução de conflitos}

Especificamente para este caso, a avaliação diz respeito à freqüência com que é usado cada um dos estilos de gestão de conflitos, numa escala com intervalo entre nunca (1) e sempre (5). Cada uma das cinco abordagens para resolução de conflitos, conforme apresentado anteriormente, foi contemplada com uma única assertiva conforme validado pelas pesquisas de Mohr e Spekman (1994), Monczka et al (1998) e Medina-Muñoz e García-Falcón (2000) que serviram de referência para a adaptação dos itens apresentados a seguir:

1. Satisfazer o próprio interesse em detrimento da outra parte - Dominação.

2. Buscar em conjunto uma solução integrativa - Colaboração.

3. Ignorar ou negar-se a reconhecer o conflito - Subestimação.

4. Ceder para satisfazer a outra parte - Acomodação.

5. Chegar a um acordo de meio-termo - Compromisso.

\subsubsection{Satisfação geral}

Este atributo foi utilizado para verificar o grau de sucesso da parceria, adaptando os itens utilizados por Lee (2001) em uma pesquisa no contexto de joint-ventures internacionais entre fornecedor e distribuidor. As assertivas respectivas seguem abaixo:

1. Estamos satisfeitos com nosso relacionamento com este fornecedor.

2. Gostaríamos que outros fornecedores nossos fossem como este. 
3. Estamos satisfeitos em trabalhar com este fornecedor.

4. Gostaríamos de continuar nosso relacionamento com este fornecedor no futuro.

5. Estamos satisfeitos com o suporte e serviços recebidos deste fornecedor.

As assertivas foram validadas por meio de um pré-teste realizado com seis especialistas, entre acadêmicos e profissionais da área de suprimentos, para verificar aspectos como: clareza das instruções, organização geral, entendimento do fraseado, adequação da terminologia empregada, repetibilidade e ambigüidade das palavras e das afirmações (HENSLEY, 1999).

Também a verificação da relação entre as assertivas e o construto que elas pretendem medir foi obtida pelo pré-teste (KRAUSE, 1999).

O pré-teste tem como objetivo refinar o instrumento de pesquisa e, após sua realização, o questionário normalmente requer revisão, de forma a contribuir para a validade e confiabilidade das medidas, assim como torná-lo de uso mais fácil (FLYNN et al, 1990; FREITAS et al, 2000).

Os comentários obtidos com os especialistas que participaram do pré-teste e as análises realizadas após o mesmo, levaram a modificação em algumas assertivas para tornar o texto mais claro e mais impessoal, eliminar dupla interpretação e adequar certos termos utilizados. A modificação mais significativa foi efetuada na assertiva 1 do atributo "Confiança" (item 3.4.2.1), que foi alterada para: Podemos contar com este fornecedor para executar ações eficazes em atendimento aos objetivos da nossa empresa.

O instrumento de pesquisa final revisado e que foi encaminhado aos respondentes consta do Apêndice 2.

Outras formas de coleta de dados e informações foram a observação direta e a análise de documentação e arquivos que subsidiaram a caracterização da empresa e contribuíram para validar as informações obtidas com as entrevistas e com os questionários aplicados. 


\subsection{Procedimento de análise dos dados}

De acordo com Lakatos e Marconi (1991), o método de abordagem do problema é o nível de abstração mais elevado para tratar os fenômenos da natureza e da sociedade. Utiliza-se do raciocínio para coletar elementos que propiciem a compreensão dos fatos e baseia-se em dois procedimentos básicos:

- $\quad$ Dedução = parte do geral para o particular; tem o propósito de explicar o conteúdo das premissas e nos oferece certezas;

- Indução = parte de uma análise de dados particulares e se encaminha para noções gerais; tem o desígnio de ampliar o alcance do conhecimento e nos oferece possibilidades.

Neste trabalho, a abordagem dedutiva é utilizada na fundamentação teórica, buscando conceitos que dêem sustentação ao assunto que se pretende estudar. Por outro lado, a coleta de dados e informações, bem como a análise de dados e resultados, utilizam a abordagem indutiva, com o propósito de ampliar os conhecimentos captados pelo estudo de caso.

Nesta etapa do trabalho busca-se organizar os dados coletados de forma a que se obtenham padrões, verifique-se a consistência ou não com a teoria desenvolvida e amplie-se o conhecimento sobre o tema estudado.

\subsubsection{Análise do estudo de caso}

Nesta etapa utiliza-se o método de comparações entre as informações coletadas e a teoria apresentada, adotando-se o estilo de descrição narrativa, podendo-se utilizar citações de excertos das entrevistas realizadas (YIN, 1994).

Esta análise foi constituída de quatro fases englobando: análise documental e das anotações efetuadas durante a observação direta - contextualizar a empresa e o setor estudados; análise isolada das informações de cada entrevista - conhecer e caracterizar o relacionamento; análise comparativa entre as entrevistas - evidenciar convergências e divergências; análise conjunta da totalidade das informações coletadas - generalizar os conceitos. 
Na primeira fase foram reunidos os dados coletados e recorreu-se a uma abordagem histórica para reconstituir a evolução do setor e da empresa, de forma geral, e do modelo de relacionamento, em particular.

$\mathrm{Na}$ segunda etapa foram agrupadas as informações coletadas em cada entrevista de forma a conhecer e caracterizar os aspectos gerais da parceria do fabricante com os fornecedores.

$\mathrm{Na}$ terceira fase utilizou-se procedimento comparativo, confrontando as informações coletadas em cada entrevista e buscando evidenciar convergências e divergências presentes nas visões e interpretações dos gerentes quanto à parceria.

Finalmente, todos os conjuntos de informações obtidos e analisados nas fases anteriores foram confrontados de forma a obter uma visão ampla e mais generalizada da parceria e dos conceitos teóricos correspondentes.

\subsubsection{Análise dos dados coletados}

Nesta etapa buscou-se observar as características componentes do modelo conceitual apresentado no capítulo anterior (ver Figura 4) por meio da análise dos dados obtidos através do questionário utilizado para medir os construtos respectivos.

Como primeiro passo, uma análise descritiva dos dados foi efetuada, envolvendo frequiências simples e acumulada, moda e estatísticas de ordem, com o objetivo de identificar o aspecto preponderante de cada uma das características avaliadas, vistas de forma isolada.

De acordo com Pestana e Gageiro (2000), por se tratarem de variáveis ordinais, estes indicadores citados acima são os mais relevantes e apropriados para descrever os dados coletados pelo questionário.

Como passo complementar, buscou-se analisar a presença de relação de correspondência entre os construtos mensurados através do questionário aplicado, conforme sugerido pelo modelo conceitual. Para tanto, utilizou-se a tabela de contingência como instrumento de verificação da associação entre os construtos estudados. 
A tabela de contingência permite a análise de variáveis qualitativas através do cruzamento das mesmas, de forma a verificar a existência de relação de dependência entre elas, que pode ou não ser causal (PESTANA; GAGEIRO, 2000).

O mecanismo da tabela de contingência foi aplicado como forma de agrupar e relacionar os dados coletados para mensurar os construtos presentes no modelo conceitual, visando propiciar uma interpretação qualitativa e argumentativa da relação entre as características estudadas, mas sem qualquer pretensão de inferência estatística. De acordo com Pestana e Gageiro (2000), trata-se de uma técnica exploratória e não confirmatória, cujo objetivo é identificar possíveis relações entre variáveis qualitativas.

Como os construtos foram medidos por uma escala multi-item, para esta análise, os mesmos foram rearranjados pela média de seus respectivos itens, resultando em construtos de item único para cada uma das características estudadas (LEE, 2001; KUMAR et al, 1995). Este procedimento é validado por Pestana e Gageiro (2000) que afirmam que pode ser dado tratamento quantitativo, como o cálculo de médias, para variáveis ordinais que possuam mais de três categorias, como é o caso deste estudo.

A análise descritiva realizada nesta etapa teve como suporte a ferramenta computacional estatística SPSS $^{3}$.

\subsubsection{Análise dos resultados}

Esta etapa caracterizou-se pelo cruzamento das informações e dados coletados através da observação direta, da análise documental, das entrevistas e do questionário aplicado, acrescido da comparação dos mesmos com a fundamentação teórica realizada.

Este procedimento caracteriza o processo de triangulação.

Esse mecanismo de utilizar múltiplos métodos e variadas fontes para uma checagem cruzada das informações pode aumentar a confiabilidade dos resultados alcançados e contribui para a validação interna e externa da pesquisa (YIN, 1994; MALHOTRA; GROVER, 1998).

\footnotetext{
${ }^{3}$ Statistical Package for the Social Sciences.
} 
Adicionalmente, Ramsay (1998) argumenta que essa prática de utilizar mais de uma fonte de dados, obtidas por diferentes métodos de coleta, propicia credibilidade às conclusões, interpretações ou generalizações do estudo empreendido.

Este capítulo detalhou a metodologia aplicada neste trabalho. Discutiu a utilização do estudo de caso, em associação com um questionário estruturado, para desenvolver a compreensão das características chave presentes em uma parceria fabricante-fornecedor, e concluiu com a forma adotada para efetuar a análise dos dados coletados.

O próximo capítulo detalha as características da empresa utilizada para o estudo de caso Embraer, e do segmento industrial - aeroespacial, no qual a mesma está inserida. 


\section{CARACTERIZAÇÃO DO SETOR E DA EMPRESA}

Este capítulo detalha o ambiente no qual está inserida a empresa que é objeto deste estudo de caso - Embraer. Apresenta, inicialmente, o segmento industrial - aeroespacial, ao qual a empresa pertence. Traça um perfil da evolução deste segmento em termos mundiais e no Brasil, sob a ótica da cadeia de suprimentos e dos relacionamentos entre seus agentes. Reconstitui o processo histórico da Embraer desde seu início até o presente, uma vez que os acontecimentos passados são fundamentais para o entendimento do modelo de parceria que é foco deste trabalho. Em seguida, discute a estrutura de gestão da cadeia de suprimentos e do relacionamento com os fornecedores. Para concluir, faz uma descrição da evolução do modelo de parceria com os fornecedores e caracteriza o foco de estudo deste trabalho.

\subsection{A indústria aeronáutica}

A indústria aeronáutica é um dos maiores setores de alta tecnologia no mundo. Esta indústria está inserida no segmento aeroespacial, o qual engloba empresas que produzem aviões, mísseis guiados, veículos espaciais, motores de aviões, unidades de propulsão e respectivos componentes e partes.

\subsubsection{Visão geral}

O setor aeronáutico caracteriza-se por produtos de alto valor agregado, sendo fortemente afetado por escala e "timing" (tempo de resposta ao mercado, em função dos longos ciclos de desenvolvimento). Seu sucesso está atrelado a rápidos progressos tecnológicos e, portanto, as atividades de pesquisa e desenvolvimento são essenciais.

A indústria aeronáutica é dividida em dois segmentos principais: comercial (civil) e militar. De acordo com Cassiolato et al (2002), ambos os segmentos apresentam dinâmicas muito diferenciadas do ponto de vista econômico, produtivo, tecnológico e logístico. 
O setor de manufatura de aviação civil é um dos mais importantes da indústria aeronáutica e representa a maior porção desta indústria, contemplando diversas divisões em função do tipo de produto fabricado: aviões de grande porte, aviões regionais, jatos executivos, helicópteros, motores, radares, etc. De acordo com Schmitt (2000), esse setor vem tornando-se cada vez mais importante devido ao forte crescimento da aviação comercial em geral.

Os maiores clientes da indústria de aviação civil são as linhas aéreas comerciais e as empresas de transporte de cargas.

Os quatro maiores fabricantes mundiais de aeronaves civis são: Airbus e Boeing para aviões de grande porte - acima de 120 assentos, e Embraer e Bombardier para aviões de médio porte - entre 10 e 120 assentos (NIOSI; ZHEGU, 2005; CASSIOLATO et al, 2002).

De acordo com Cassiolato et al (2002), o segmento de aeronaves civis apresenta diversos fatores competitivos importantes, tanto internos como externos às empresas, conforme resumido no Quadro 5.

A concentração econômica na indústria aeronáutica é muito grande, com poucos competidores e, portanto, a competição é muito forte. Esta concentração está diretamente ligada à necessidade de enfrentar e superar barreiras tecnológicas - associadas ao desenvolvimento de produtos complexos e de alta tecnologia, e barreiras econômicas associadas ao risco e ao alto comprometimento de capital requerido para projetar e produzir aeronaves (ESPOSITO, 2004; NIOSI; ZHEGU, 2005).

Adicionalmente, Schmitt (2000) afirma que a concentração torna-se essencial para reduzir duplicação de esforços, para partilhar recursos para pesquisa e desenvolvimento, e para aumentar a participação de mercado, sendo também uma forma pela qual as empresas podem expandir sua gama de produtos e sustentar os investimentos necessários.

De acordo com Niosi e Zhegu (2005), a indústria aeronáutica é concentrada em regiões especializadas, caracterizadas por uma grande inércia geográfica devido aos altos valores imobilizados em grandes fábricas com equipamentos caros, complexos e sofisticados. Como exemplos, podem ser citados: a região de Seattle/EUA (sede da Boeing), com mais de 50 anos; a região de Toulouse/França (sede da Airbus), com cerca de um século; a região de 
Montreal/Canadá (sede da Bombardier), com mais de 80 anos; a região de São José dos Campos/ Brasil (sede da Embraer), com mais de trinta anos.

Quadro 5 - Fatores críticos de competitividade na indústria de aeronaves civis

\begin{tabular}{|c|c|}
\hline Interno à empresa & $\begin{array}{l}\text { - Marca registrada } \\
\text { - Projeto } \\
\text { - Fomentar pesquisa e desenvolvimento } \\
\text { - Foco na competência estratégica } \\
\text { - Inteligência de mercado - logística, produtividade, } \\
\text { propaganda, recursos humanos, suporte técnico, } \\
\text { estrutura de financiamento. }\end{array}$ \\
\hline Produto & $\begin{array}{l}\text { - Imagem } \\
\text { - "Time to market" } \\
\text { - Inovação } \\
\text { - Fator de aversão a diferentes tipos de motor } \\
\text { - Conceito de família } \\
\text { - Comunalidade } \\
\text { - Custo por assento } \\
\text { - Custos operacionais } \\
\text { - Despachabilidade }\end{array}$ \\
\hline Mercado & $\begin{array}{l}\text { - Estrutura concentrada } \\
\text { - Nichos } \\
\text { - Substituição dos aviões turboélice por jatos } \\
\text { - Segmentação técnica } \\
\text { - Global } \\
\text { - Compradores seletivos e restritos } \\
\end{array}$ \\
\hline Configuração industrial & $\begin{array}{l}\text { - Alianças estratégicas } \\
\text { - Economia especializada } \\
\text { - Interação com usuários } \\
\text { - Sistema científico e tecnológico forte }\end{array}$ \\
\hline Incentivos e regimes regulatórios & $\begin{array}{l}\text { - Suporte a pesquisa e desenvolvimento } \\
\text { - Subsídio governamental } \\
\text { - Incentivos alfandegários } \\
\text { - Proteção seletiva } \\
\text { - Financiamento de crédito e exportação }\end{array}$ \\
\hline
\end{tabular}

Fonte: CASSIOLATO et al, 2002.

A evolução da indústria aeronáutica pode ser caracterizada, ao longo do tempo, por períodos associados ao modelo de relacionamento predominante e ao processo de internacionalização (ESPOSITO, 2004; NIOSI; ZHEGU, 2005):

1) A fase da verticalização = entre o final da Segunda Guerra Mundial e início dos anos 60, houve a predominância dos Estados Unidos na produção e consumo dos produtos aeronáuticos. A tecnologia prevalente era o motor a pistão e uma aeronave era 
totalmente desenvolvida por uma única empresa, a qual era capaz de sustentar os esforços tecnológicos e financeiros necessários para desenvolver novos produtos;

2) A primeira fase colaborativa $=$ nos anos 60 , com o surgimento da tecnologia a jato, há o interesse da indústria de motores de aviação em estabelecer acordos de desenvolvimento com outras empresas. Há também acordos cooperativos entre indústrias aeronáuticas para o desenvolvimento de aviões com novas tecnologias (por ex: o Concorde para transporte supersônico). Estes acordos ocorrem principalmente entre empresas européias, interessadas em relacionamentos de cooperação operacional, para superar as barreiras tecnológicas e financeiras e para contraporem-se à supremacia americana;

3) O consórcio europeu $=$ durante os anos 70, os países europeus aceleraram a criação do consórcio Airbus, contrapondo a liderança americana. Houve também a consolidação dos acordos existentes, remanescentes da década de 60, e o surgimento de novos acordos no setor de motores. Estes acordos, além dos aspectos financeiros e tecnológicos, foram motivados também pela necessidade de reduzir os riscos de mercado e de ampliar a demanda potencial;

4) A difusão mundial da indústria $=$ durante os anos 80 , consolidou-se a tendência de internacionalização da indústria aeronáutica e a partir do final dos anos 80, a cooperação internacional entre membros da indústria aeronáutica intensificou-se. Este período caracterizou-se por uma nova descontinuidade tecnológica - o desenvolvimento de novos materiais (por ex.: fibra de carbono), de sistemas de propulsão de alto desempenho e de eletrônica embarcada, exigindo um enorme aporte de capital;

5) A crise $=$ no início dos anos 90, a indústria aeronáutica é afetada pela forte queda da demanda mundial com a redução drástica do faturamento das empresas. A tendência de cooperação ao redor do mundo cresceu entre empresas, inclusive na indústria americana, como forma de viabilizar o desenvolvimento de projetos voltados às novas exigências do mercado - aviões melhores, mais rápidos e mais baratos, o que exigia o compartilhamento dos riscos. O colapso do sistema comunista permitiu às empresas ocidentais ingressar no mercado do leste e oriente, e estabelecer relacionamentos com empresas locais. A guerra entre Airbus e Boeing pela liderança do mercado mundial tornou-se ainda mais acirrada;

6) A integração industrial = na segunda metade dos anos 90, com a retomada da demanda mundial, os esforços tecnológicos e financeiros necessários para acompanhar as exigências do mercado mundial levaram a indústria aeronáutica no sentido da integração, tanto na Europa como nos Estados Unidos. Segundo Schmitt (2000), uma 
onda de fusões e aquisições reduziu drasticamente o número de empresas e gerou gigantes do setor aeroespacial, levando à consolidação desta indústria, como pode ser visto nos Anexos 1 e 2. Em 1999, pela primeira vez na história, a carteira de pedidos da Airbus supera a da Boeing;

7) A reorganização mundial = no início dos anos 2000, o cenário competitivo muda, tanto a nível local como internacional, em função da ascendência dos grandes conglomerados mundiais. Essa concentração industrial tem gerado uma maior concorrência tecnológica nos mercados em que atuam esses grupos e, ao mesmo tempo, tem reforçado a colaboração internacional entre eles para pesquisa e desenvolvimento (por ex.: a americana Boeing buscando apoio da BAE inglesa para um projeto de avião supersônico).

No Anexo 3 são apresentados os acordos de cooperação ocorridos na indústria aeronáutica durante o período acima abordado (entre os anos 50 e 2000).

Esposito (2004) afirma que o sucesso das empresas aeronáuticas está baseado em uma complexa rede de relacionamentos de longo prazo, envolvendo colaboração e competição, o que influencia tanto a variedade quanto a qualidade dos produtos no mercado. A estrutura da rede de relacionamentos da cadeia de suprimentos desta indústria é apresentada a seguir.

\subsubsection{A cadeia de suprimentos aeronáutica}

As atividades da indústria aeronáutica dependem de componentes e partes que são oriundos de diversos tipos de indústrias, estando estas largamente dispersas em termos de localização, ao mesmo tempo em que o mercado consumidor não é limitado geograficamente (NIOSI; ZHEGU, 2005).

A cadeia de suprimentos da indústria aeronáutica é organizada de forma hierárquica e estratificada, conforme sumarizado na Figura 8, de acordo com as tecnologias fornecidas e as atividades executadas pelos fabricantes, sendo liderada pelas empresas montadoras de aeronaves.

À medida que se sobe na cadeia de suprimentos, aumenta a integração tecnológica e a especialização em projeto e desenvolvimento de produto. Por outro lado, ao descer na cadeia, cresce a especialização em tecnologia e processos de produção. 
No Anexo 4 pode ser visto um diagrama esquemático do processo de manufatura na indústria aeroespacial.

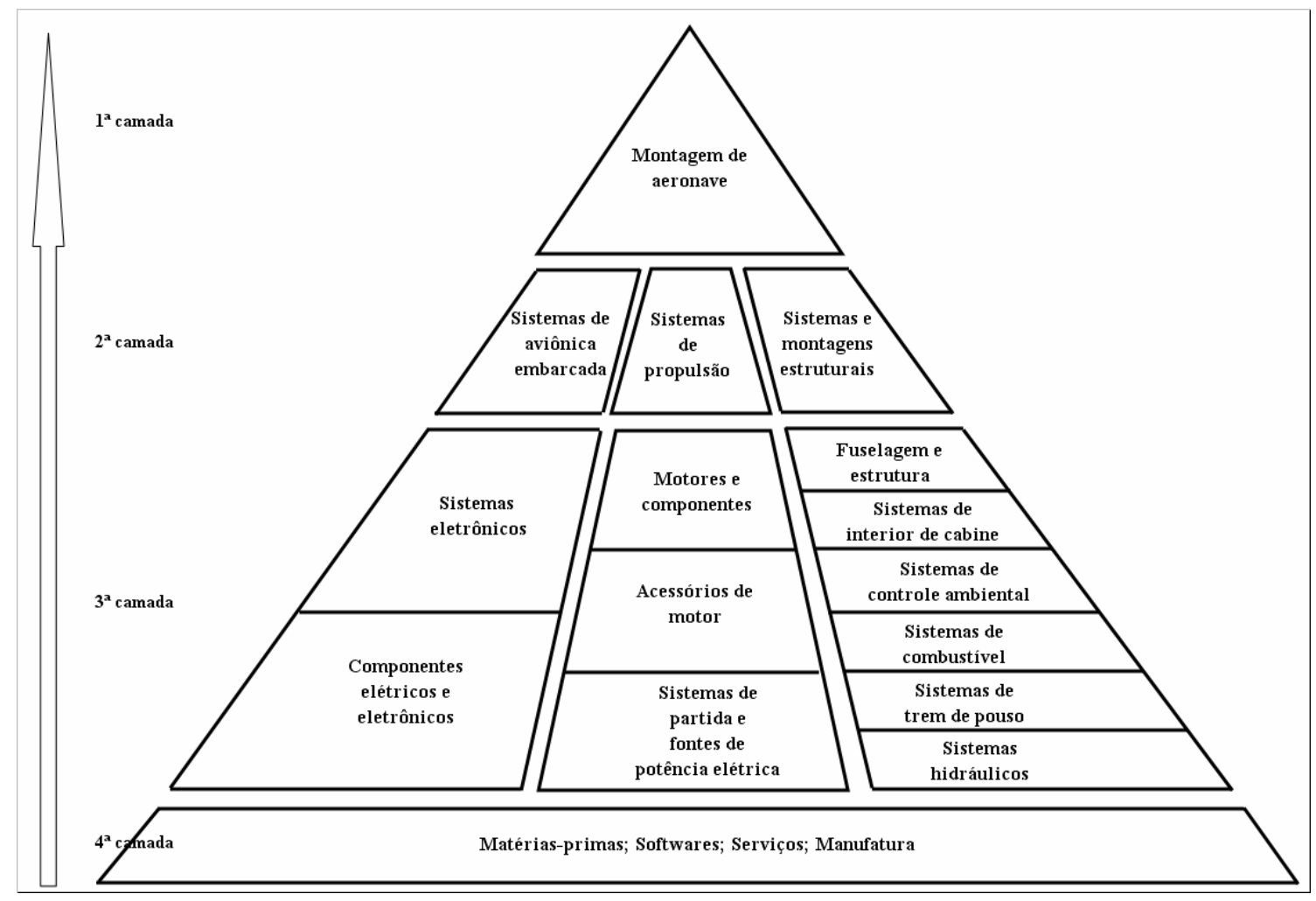

Figura 8 - Estrutura da cadeia de suprimentos aeronáutica Fontes: NIOSI; ZHEGU, 2005; AECMA ${ }^{4}, 2004$.

Conforme ilustrado na figura acima, no topo da pirâmide estão as montadoras de aeronaves (também conhecidos como "Contratantes principais" ou "OEMs" "), tais como Boeing, Airbus, Embraer, Eurocopter e Bombardier, que lideram a cadeia. Essas empresas são as responsáveis pelo projeto e desenvolvimento do produto, prospecção de mercados, compra de submontagens da segunda camada e manufatura final do produto. Para o desenvolvimento do produto, estas empresas buscam identificar as necessidades das empresas aéreas, baseadas em uma série de fatores, tais como: rotas de vôo, tamanho da aeronave, capacidade de carga, alcance, arranjo e número de assentos, consumo, velocidade, entre outros. O sucesso do produto no mercado está associado a dois aspectos fundamentais: a capacidade de atender essas necessidades ao menor custo total e as condições favoráveis de financiamento.

\footnotetext{
${ }^{4}$ European Association of Aerospace Industries

${ }^{5}$ Original Equipment Manufacturer
} 
$\mathrm{Na}$ segunda camada estão as empresas que fazem grandes conjuntos: os fabricantes de sistemas de propulsão (por ex.: GE, Pratt \& Whitney ou Rolls-Royce); os produtores de aviônica embarcada (como Honeywell, Rockwell Collins ou Sextant Avionique); as manufaturas de estruturas metálicas e submontagens como trem de pouso (por ex.: Latécoére, Liebherr ou Messier-Dowty). De acordo com Giunta (1999), nesta camada estão os fornecedores preferenciais, para os quais as montadoras de aeronaves estão delegando parte da tarefa de integração dos componentes através da compra de sistemas completos. Estes fornecedores mantêm um relacionamento privilegiado com a empresa líder, com a qual partilham os riscos financeiro e industrial do projeto.

$\mathrm{Na}$ terceira camada encontram-se os fabricantes de conjuntos eletrônicos, de sistemas hidráulicos, elétricos e pneumáticos (como: Parker, Hamilton ou Goodrich), sendo cada segmento dominado por um pequeno número de empresas.

A quarta camada é formada por uma gama maior de pequenos e médios fabricantes de componentes e peças, e por fornecedores de matéria-prima para os demais níveis (por ex.: Alcoa, Otto Fuchs), que não atuam exclusivamente no setor aeronáutico, mas em diversas outras indústrias.

De acordo com Niosi e Zhegu (2005), as empresas montadoras de aeronaves têm alterado suas práticas de relacionamento, ao longo da cadeia de suprimentos, do tradicional estilo americano de mercado puro (arm's lenght) para o modelo colaborativo japonês, envolvendo os fornecedores das diversas camadas, através do compartilhamento de conhecimento sobre produtos, processos e custos. Essa mudança é abordada com mais detalhes no tópico seguinte.

\subsubsection{Relacionamentos na indústria aeronáutica}

Nos últimos dez anos, os fabricantes de aeronaves civis têm competido por pedidos das companhias aéreas, as quais têm apresentado rentabilidades decrescentes no período e em função disso, os fabricantes tem atuado fortemente em redução de custos para melhorar sua competitividade. Estudos do Institute for Supply Management - ISM (2002) revelaram que aproximadamente $70 \%$ de todos os fornecedores e compradores do setor aeronáutico reportaram que custo é a prioridade competitiva número um entre eles. 
Nesta mesma linha, Choi e Rossetti (2005) evidenciaram, por meio de entrevistas com fornecedores e compradores, que a cadeia de suprimentos aeronáutica é focada na redução do preço de compra no curto prazo e que essa prática cria dissonâncias entre as partes, deteriorando irremediavelmente os relacionamentos comprador-fornecedor, ignorando objetivos corporativos e de mercado, e negligenciando a qualidade.

Para reduzir custos, os fabricantes de aeronaves têm aumentado a transferência de atividades de manufatura para os fornecedores (outsourcing) e concentrado em suas competências centrais de projeto, montagem e comercialização de aviões (NIOSI; ZHEGU, 2005). Choi e Rossetti (2005) afirmam que os fabricantes americanos chegam a subcontratar entre 50 e 70 por cento do valor total adicionado a seus produtos e continuam buscando novas oportunidades para ampliar esta participação externa.

Com o tempo, as empresas têm percebido que esse processo de outsourcing vai além da redução de custos, permitindo um alinhamento da base de fornecedores com as oportunidades de mercado do fabricante (CHOI; ROSSETTI, 2005). O Quadro 6 mostra as iniciativas que tem sido implementadas neste sentido.

Essas iniciativas de fornecimento visam alterar os relacionamentos comprador-fornecedor de transações esporádicas de curto prazo para transações seqüenciais de longo prazo, melhorando as eficiências operacionais de ambas as partes. Isso significa basear o relacionamento em redução de custos associada ao aumento de eficiência no longo prazo e não simplesmente em redução de preço no curto prazo (CHOI; ROSSETTI, 2005).

Para tanto, os fabricantes têm atuado no sentido de reduzir, reorganizar e racionalizar sua base de fornecedores (NIOSI; ZHEGU, 2005).

Um dos aspectos mais importantes desse processo é o estabelecimento de parcerias entre fabricantes e fornecedores, as quais tendem a maximizar a presença no mercado e a lucratividade de ambas as empresas. Adicionalmente, a parceria gera uma expectativa de relacionamento de longo prazo, de confiança e de melhor comunicação, contribuindo para o aumento da eficiência das empresas pela redução dos custos de transação (CHOI; ROSSETTI, 2005). 
Quadro 6 - Estratégias de fornecimento

\begin{tabular}{|c|c|c|}
\hline Iniciativas de fornecimento & Definição & Resultados esperados \\
\hline $\begin{array}{l}\text { Racionalização da base de } \\
\text { fornecedores }\end{array}$ & $\begin{array}{l}\text { Redução do número total de } \\
\text { fornecedores }\end{array}$ & $\begin{array}{l}\text { - Redução dos recursos para } \\
\text { gestão de fornecedores } \\
\text { - Relacionamento mais } \\
\text { focado }\end{array}$ \\
\hline Gestão de commodity & $\begin{array}{l}\text { Alinhar as necessidades } \\
\text { corporativas de peças de } \\
\text { materiais e processos } \\
\text { similares com a capacidade } \\
\text { da base de fornecimento }\end{array}$ & $\begin{array}{l}\text { - Aumentar conhecimento do } \\
\text { mercado de fornecimento } \\
\text { - Redução de custo interno } \\
\text { do fornecedor devido a } \\
\text { economias de escala } \\
\text { - Relação técnica mais } \\
\text { próxima entre as partes }\end{array}$ \\
\hline Consolidação de compras & $\begin{array}{l}\text { Aumentar o total comprado } \\
\text { de um fornecedor }\end{array}$ & $\begin{array}{l}\text { - Aumento da alavancagem } \\
\text { de compras } \\
\text { - Aumento da dependência } \\
\text { comprador-fornecedor }\end{array}$ \\
\hline Fornecimento global & $\begin{array}{l}\text { Explorar o mercado global } \\
\text { para melhorar capacidades } \\
\text { (ex.: redução do custo de } \\
\text { mão de obra) }\end{array}$ & $\begin{array}{l}\text { - Redução do custo unitário } \\
\text { - Aumento da competição no } \\
\text { mercado fornecedor }\end{array}$ \\
\hline Acordos de fonte única & $\begin{array}{l}\text { Comprar um produto ou uma } \\
\text { família de produtos de um } \\
\text { fornecedor }\end{array}$ & $\begin{array}{l}\text { - Redução de preço } \\
\text { - Aumento da dependência } \\
\text { comprador-fornecedor }\end{array}$ \\
\hline Acordos de longo prazo & $\begin{array}{l}\text { Entendimento de que o } \\
\text { relacionamento comprador- } \\
\text { fornecedor se estenderá por } \\
\text { anos ou indefinidamente }\end{array}$ & $\begin{array}{l}\text { - Melhoria da qualidade, } \\
\text { entrega e preço devido a } \\
\text { investimentos específicos } \\
\text { - Expectativa de confiança e } \\
\text { prosperidade mútuas }\end{array}$ \\
\hline Compra JIT (just-in-time) & $\begin{array}{l}\text { Minimizar o tempo de } \\
\text { fornecimento }\end{array}$ & $\begin{array}{l}\text { - Redução do nível de } \\
\text { inventário } \\
\text { - Melhoria do tempo de } \\
\text { resposta do fornecedor }\end{array}$ \\
\hline
\end{tabular}

Fonte: CHOI; ROSSETTI, 2005.

\subsubsection{A indústria aeronáutica no Brasil}

O histórico da indústria aeronáutica brasileira remonta à década de 30 , com a primeira produção em série de aeronaves tendo sido feita pela Companhia Nacional de Navegação Costeira, apoiada pelo governo Getúlio Vargas, e posteriormente, pela Fábrica Nacional de Aviões, tendo resultado na produção de vários modelos de aviões de pequeno porte até 1948 . 
Em 1941, nasce a Fábrica do Galeão por iniciativa da Marinha, visando inicialmente resolver os problemas de manutenção de seus aviões, mas atuando posteriormente na fabricação de diversos modelos de aeronaves, através de acordos de licenciamento com a Alemanha e a Inglaterra.

Em 1942 surge a Companhia Aeronáutica Paulista (CPA) que produziu modelos projetados pela divisão de aeronáutica do Instituto de Pesquisas Tecnológicas (IPT) da Universidade de São Paulo (USP), com destaque para o "Paulistinha", o modelo de maior sucesso comercial da década de 40.

Até aqui, as iniciativas no setor eram dependentes de empreendedores privados.

Nesta mesma época, deu-se a criação do Ministério da Aeronáutica, em conjunto com a Força Aérea Brasileira (FAB), pela aglutinação dos meios aéreos existentes da aviação militar do Exército Brasileiro e da aviação naval da Marinha Brasileira. O governo passa então a atuar de forma estratégica no setor aeronáutico, tomando medidas de longo prazo visando implementar uma política para viabilizar a indústria de fabricação de aeronaves no país, buscando autonomia neste setor, especialmente em matéria de produtos de defesa.

O marco nesta direção foi a criação do Centro Técnico Aeroespacial (CTA) em 1945, através de um acordo de cooperação com o Massachussets Institute of Technology (MIT). Em 1947, nasce o Instituto Tecnológico de Aeronáutica (ITA) com o objetivo de formar engenheiros especializados em aeronáutica. O objetivo principal destas iniciativas governamentais era estabelecer, desenvolver e adquirir capacidade para a manufatura de aeronaves, ou seja, criar uma indústria nacional de aeronaves (CASSIOLATO et al, 2002).

A atuação do empreendedor privado manteve-se na década de 50, com a criação da Sociedade Construtora Aeronáutica Neiva que retoma e atualiza o projeto do avião "Paulistinha", cedido pela CPA, e principalmente, desenvolve o "Regente", a primeira aeronave brasileira totalmente produzida em metal, tornando-se um marco para seu desenvolvimento tecnológico.

Em seu início, o CTA e o ITA estavam localizados no Rio de Janeiro, capital da República naquela época, tendo sido transferidos em 1950 para São José dos Campos, a qual veio a se tornar o pólo da indústria aeronáutica nacional. Até a metade da década de 50, o foco de 
atuação estava na formação de mão-de-obra especializada e massa crítica com alto grau de conhecimento técnico. A partir de então, iniciam-se as atividades de pesquisa em áreas básicas como motores, materiais, eletrônica, projeto de aeronaves e testes de vôo, através do Instituto de Pesquisa e Desenvolvimento (IPD), criado pelo CTA com o objetivo de estudar os problemas técnicos, econômicos e operacionais relacionados com a aeronáutica, cooperar com a indústria e buscar soluções adequadas às atividades da aviação nacional (CTA, 2006).

Em 1954, o IPD concebeu o projeto do "Convertiplano" - uma aeronave de decolagem vertical e trajetória de vôo horizontal, do qual resultou o protótipo de um helicóptero de dois lugares - o "Beija-Flor", o qual fez seu vôo inicial em Fevereiro de 1958. A evolução dos conhecimentos adquiridos pelo IPD consolida-se, em Outubro de 1968, com o vôo oficial da aeronave "Bandeirante" - um avião bimotor turboélice para 12 passageiros, numa demonstração da existência de condições, competência e capacidade para consolidação dos planos de criação de uma indústria aeronáutica brasileira.

O processo natural resultante desses desenvolvimentos tecnológicos e de formação de recursos humanos foi a criação de uma empresa estatal para a fabricação de aeronaves. Assim, em 1969, surge a Empresa Brasileira de Aeronáutica (Embraer), ligada ao Ministério da Aeronáutica, tendo o Governo Brasileiro como acionista majoritário (51\% do capital votante).

De acordo com Dagnino (1993), quando da fundação da Embraer, foi transferida para a empresa, pelo IPD, uma grande quantidade de equipamentos para a produção, e a totalidade da equipe técnica que havia desenvolvido o "Bandeirante". As atividades de manufatura iniciaram em Janeiro de 1970, com mão-de-obra direta recrutada da indústria automobilística que havia se instalado no Brasil no final dos anos 50 (CASSIOLATO et al, 2002).

Desde então, a história e a evolução da indústria aeronáutica brasileira se confunde com a da própria Embraer.

O Quadro 7 resume os eventos mais importantes que afetaram a evolução da indústria aeronáutica brasileira entre seu início e a privatização da Embraer. 
Quadro 7 - Principais eventos na evolução da indústria aeronáutica brasileira (1945 a 1994)

\begin{tabular}{|c|c|}
\hline Período & Eventos \\
\hline 1945 & $\begin{array}{l}\text { Criação do Centro Técnico Aeroespacial (CTA), como uma instituição do Ministério da } \\
\text { Aeronáutica, através de acordo de cooperação com o Massachussets Institute of Technology } \\
(M I T) \text {. }\end{array}$ \\
\hline 1947 & Criação do Instituto Tecnológico de Aeronáutica (ITA) pelo CTA. \\
\hline 1950 & Transferência do CTA e ITA do Rio de Janeiro para São José dos Campos. \\
\hline 1954 & $\begin{array}{l}\text { - O Instituto de Pesquisa e Desenvolvimento (IPD) é criado no CTA para desenvolver pesquisa } \\
\text { em áreas básicas como motores, materiais, eletrônica, projeto de aeronaves e testes de vôo. } \\
\text { - O projeto "Convertiplano" é concebido pelo IPD. } \\
\text { - Inicia-se o projeto do helicóptero "Beija-Flor" pelo IPD. }\end{array}$ \\
\hline 1958 & $\begin{array}{l}\text { O "Beija-Flor" faz seu primeiro vôo, sendo alcançado um importante estágio pela engenharia } \\
\text { aeronáutica brasileira, pois se tratava do primeiro helicóptero projetado e construído no Brasil. }\end{array}$ \\
\hline 1965 & $\begin{array}{l}\text { Inicia-se o desenvolvimento e construção pelo IPD do projeto "Bandeirante" - aeronave de } \\
\text { passageiros de médio porte. }\end{array}$ \\
\hline 1968 & Construção e vôo do primeiro protótipo do avião "Bandeirante". \\
\hline 1969 & $\begin{array}{l}\text { - Criação da Empresa Brasileira de Aeronáutica (Embraer) como sociedade de economia mista } \\
\text { controlada pelo Governo Federal, destinada à fabricação seriada do avião Bandeirante. } \\
\text { - Vôo do segundo protótipo do avião "Bandeirante". }\end{array}$ \\
\hline 1970 & Embraer inicia suas atividades de manufatura. \\
\hline 1971 & $\begin{array}{l}\text { - Início da produção em série do avião "Bandeirante". } \\
\text { - Fabricação do planador "Urupema". } \\
\text { - Lançamento do "Ipanema", projetado pelo IPD para o setor agrícola. } \\
\text { - Lançamento do "Xavante", avião projetado para o segmento militar, através de acordo de } \\
\text { licenciamento com empresa italiana Aermacchi. }\end{array}$ \\
\hline 1973 & Entrega do avião "Bandeirante" para aviação comercial no Brasil. \\
\hline 1974 & $\begin{array}{l}\text { Colocado em prática o acordo para fabricação sob licença pela Embraer dos aviões da norte- } \\
\text { americana Piper. }\end{array}$ \\
\hline 1975 & $\begin{array}{l}\text { Início da atuação da Embraer no mercado internacional com a exportação dos aviões } \\
\text { "Bandeirante" e "Ipanema". }\end{array}$ \\
\hline 1976 & $\begin{array}{l}\text { Lançamento do "Xingu" - aeronave executiva pressurizada, primeira aeronave projetada e } \\
\text { fabricada pela Embraer. }\end{array}$ \\
\hline 1978 & Lançamento do "Tucano" - aeronave de treinamento militar. \\
\hline 1979 & $\begin{array}{l}\text { Estabelecida a subsidiária Embraer Aircraft Company (EAC), sediada em Fort Lauderdale, } \\
\text { Flórida, EUA, para vendas e apoio técnico aos clientes na América do Norte. }\end{array}$ \\
\hline 1980 & Desenvolvimento do "Brasília" - avião turboélice, pressurizado, para 30 passageiros. \\
\hline 1981 & $\begin{array}{l}\text { Embraer estabelece acordo com as empresas italianas Aeritalia (hoje Alenia) e Aermacchi para o } \\
\text { desenvolvimento e fabricação do AMX, caça bombardeiro subsônico de nova geração. }\end{array}$ \\
\hline 1983 & $\begin{array}{l}\text { Estabelecimento da Embraer Aviation International (EAI), sediada em Paris, França, para } \\
\text { concentrar atividades de vendas e apoio técnico aos clientes na Europa, Oriente Médio e Âfrica. }\end{array}$ \\
\hline 1988 & $\begin{array}{l}\text { Em parceria com a empresa argentina Fábrica Militar de Aviones (FMA), a Embraer começa o } \\
\text { desenvolvimento do CBA } 123 \text {, aeronave turboélice para } 19 \text { passageiros que não chegou a ser } \\
\text { produzida em série, mas foi a base tecnológica para o projeto ERJ } 145 \text {. }\end{array}$ \\
\hline 1989 & Início do projeto ERJ 145, primeiro jato produzido pela Embraer. \\
\hline 1993 & A Embraer estabelece acordos de parceria para o desenvolvimento do ERJ 145. \\
\hline 1994 & Privatização da Embraer. \\
\hline
\end{tabular}

Fontes: Embraer, 2006; Cassiolato et al, 2002. 
O plano inicial, traçado pelo Governo para a Embraer, era fabricar aeronaves projetadas por engenheiros e técnicos brasileiros, objetivando a aquisição de autonomia tecnológica, ou seja, adquirir o conhecimento do ciclo completo de desenvolvimento e manufatura de aeronaves (CASSIOLATO et al, 2002).

A adoção de uma estratégia orientada para a autonomia tecnológica foi baseada na aquisição de capacitação, em um conjunto restrito e criteriosamente selecionado de tecnologias, e em uma adequada combinação entre conhecimento desenvolvido localmente e conhecimento adquirido através de acordos de transferência de tecnologia, consultoria externa e licenciamento. Desta forma, diversas capacitações foram assimiladas, valendo destacar a aquisição de conhecimentos nas seguintes áreas: em produção industrial - com a fabricação do avião militar "Xavante" mediante acordo com a empresa italiana Aermacchi; em comercialização - mediante acordo com a empresa americana Piper; em assistência técnica e manutenção de aeronaves - através de acordos com operadores (linhas aéreas); em fabricação de componentes complexos - por meio de fornecimento sob encomenda para as americanas Boeing e McDonnell Douglas, e em tecnologia inovadora - mediante treinamento tecnológico em soldagem de metais, em material composto e em equipamentos de controle digital obtido junto à Northrop Grumman dos Estados Unidos através do pacote de compra dos aviões F-5 (DAGNINO, 1993; CASSIOLATO et al, 2002).

De acordo com Cassiolato et al (2002), a Embraer direcionou seus esforços para o treinamento e desenvolvimento de capacidade em duas áreas básicas: projeto de avião aerodinâmica e fuselagem, e integração de sistemas e componentes não fabricados por ela. A idéia foi desenvolver competências e habilidades próprias, ao invés de importar pacotes tecnológicos (“caixas pretas”) para adaptação e eventual otimização.

Conforme mostrado no Quadro 7, entre os anos 70 e 80, a Embraer desenvolveu e comercializou uma série de produtos com sucesso. A empresa conquistou o mercado de transporte aéreo regional, nacional e internacional, com os aviões "Bandeirante" e "Brasília", os quais tornaram-se lideres no mercado americano na sua categoria, fazendo com que a empresa adquirisse reputação internacional. 
O Governo Federal mantinha suporte financeiro sólido e contínuo através de alocação de recursos orçamentários para a gestão da empresa, para infra-estrutura de ciência e tecnologia em São José dos Campos e para aquisição de produtos (CASSIOLATO et al, 2002).

No final dos anos 80 e início dos anos 90, a Embraer foi fortemente afetada pela crise política e econômica no Brasil, em função das reformas estruturais que levaram a uma significativa redução dos investimentos e gastos governamentais nos setores de aeronáutica, espaço e defesa, e pela recessão mundial no mercado de aviação regional.

Adicionalmente, a empresa experimentou problemas financeiros pelas seguintes razões citadas por Cassiolato et al (2002):

- A empresa havia iniciado novos projetos sem amparo financeiro apropriado;

- Os projetos foram desenvolvidos sem pesquisa detalhada de mercado e sem preocupação com as necessidades dos clientes potenciais;

- A gestão da empresa era fortemente baseada em uma visão técnica, focada em capacitação tecnológica e desenvolvimento de produto;

- Os aspectos financeiros e de custo não tinham alta prioridade.

Como resultado, a empresa perdeu competitividade rapidamente, tanto no mercado interno como externo.

Os problemas econômico-financeiros e de desempenho empresarial da Embraer, associados a uma mudança estrutural na visão do papel do estado pelo Governo Federal, levaram à privatização da empresa em 1994.

\subsection{A empresa}

A estratégia delineada pela Embraer estava baseada na premissa de que o domínio da integração de sistemas era mais crucial do que ter uma fatia expressiva do valor agregado ao avião sendo produzida no Brasil. Associando a isso a competência técnica desenvolvida em tecnologia aeronáutica, a empresa obteve independência e autonomia na tomada de decisão 
quanto à gestão do negócio, à concepção de projetos e à criação de oportunidades de mercado (CASSIOLATO et al, 2002).

Uma estratégia importante que contribuiu para o sucesso da empresa foi a adoção do conceito de "família de aviões", que significa o desenvolvimento de versões a partir de um mesmo modelo básico. Essa abordagem permite ampliar a faixa de atuação do produto no mercado com vantagens e benefícios tanto para os clientes (operadores) - menores custos de infraestrutura e manutenção da frota, treinamento padronizado para pilotos e técnicos, comunalidade da tripulação; quanto para a empresa - menores custos e mais rapidez no desenvolvimento de produto; redução dos ciclos de produção.

Adicionalmente, o crescimento significativo, nos últimos 20 anos, do mercado de “conecções" baseado em aviões a jato de menor porte veio de encontro aos produtos desenvolvidos pela empresa que eram voltados a esse mercado de aviação regional e apresentavam características diferenciadas de rapidez, baixo nível de ruído, maior autonomia e maior estabilidade de vôo, comparativamente aos aviões turboélice que dominavam este segmento.

Nos anos 90, a Embraer obteve uma importante participação no mercado mundial de aviação e tornou-se membro do seleto grupo de empresas competitivas neste setor.

O Quadro 8 apresenta os eventos mais significativos que marcaram a evolução, crescimento e sucesso alcançado pela Embraer pós-privatização.

\subsubsection{Visão geral}

A privatização promoveu uma mudança radical no modelo de gestão da empresa que passou a apoiar-se nos seguintes fundamentos:

- Satisfação do cliente como premissa básica da ação empresarial;

- Atuação global;

- Alta qualificação tecnológica e dos recursos humanos;

- Flexibilidade;

- $\quad$ Fluxo de caixa (intensidade de capital aplicado). 
Quadro 8 - Principais eventos na evolução da Embraer pós-privatização

\begin{tabular}{|c|c|}
\hline Período & Eventos \\
\hline 1994 & $\begin{array}{l}\text { - Relançamento do projeto ERJ } 145 . \\
\text { - Primeiro vôo do Super Tucano. }\end{array}$ \\
\hline 1995 & $\begin{array}{l}\text { - Primeiro vôo do avião ERJ } 145 . \\
\text { - Lançamento do programa ALX, versão armada do Super Tucano. }\end{array}$ \\
\hline 1996 & Venda de 200 aeronaves ERJ 145 na feira de Farnborough na Inglaterra. \\
\hline 1997 & $\begin{array}{l}\text { - Fechamento do maior contrato de venda de aeronaves de sua história na feira de Le Bourget } \\
\text { na França. } \\
\text { - Ampliação da "família" ERJ } 145 \text { com o desenvolvimento do ERJ } 135 \text { e dos aviões de } \\
\text { vigilância do programa Sivam. }\end{array}$ \\
\hline 1998 & Desenvolvimento do ERJ 140. \\
\hline 1999 & $\begin{array}{l}\text { - Lançamento da nova família de aeronaves EMBRAER 170/190 - composta de quatro } \\
\text { modelos: EMBRAER 170, EMBRAER 175, EMBRAER } 190 \text { e EMBRAER 195, com } \\
\text { capacidades de } 70 \text { a } 118 \text { assentos. } \\
\text { - Estabelecimento de parceria estratégica com grupo europeu de empresas aeroespaciais } \\
\text { formado pela EADS, Dassault, Thales e Snecma, que passam a integrar sua estrutura } \\
\text { societária, com } 20 \% \text { das ações com direito a voto. } \\
\text { - Criação da ELEB - Embraer Liebherr Equipamentos do Brasil S.A., através de uma "joint } \\
\text { venture" entre a Embraer - Empresa Brasileira de Aeronáutica S.A. e o grupo Liebherr } \\
\text { Aerospace, com sede na Suíça. }\end{array}$ \\
\hline 2000 & $\begin{array}{l}\text { - Entrada no mercado de Aviação Corporativa com o lançamento do programa Legacy, } \\
\text { aeronave executiva baseada na plataforma do ERJ } 135 \text {. } \\
\text { - Ampliação da atuação global com inauguração de escritórios comerciais e de pós-venda em } \\
\text { Cingapura e Beijing. }\end{array}$ \\
\hline 2001 & $\begin{array}{l}\text { - Ampliação das operações industriais com a inauguração das unidades de Eugênio de Melo e } \\
\text { GaviãoPeixoto. } \\
\text { - Primeiro vôo do ERJ } 145 \text { XR, versão com alcance maior. }\end{array}$ \\
\hline 2002 & $\begin{array}{l}\text { - Criação da unidade de manutenção em Nashville, Tennessee/EUA. } \\
\text { - Estabelecimento da joint-venture da Embraer com a empresa AVIC II, para a produção de } \\
\text { aeronaves ERJ } 145 \text { em Harbin na China. } \\
\text { - Primeiro vôo do EMBRAER } 170 \text {. }\end{array}$ \\
\hline 2003 & $\begin{array}{l}\text { - US Airways encomenda o EMBRAER 170, tornando-se cliente lançador desta aeronave nos } \\
\text { Estados Unidos. } \\
\text { - A JetBlue Airways, empresa "low-cost, low-fare" dos EUA, encomenda } 100 \text { aviões } \\
\text { EMBRAER } 190 .\end{array}$ \\
\hline 2004 & $\begin{array}{l}\text { - EMBRAER } 170 \text { entra em serviço na Europa e nos Estados Unidos. } \\
\text { - Consórcio Embraer e European Aeronautic Defense and Space Company (EADS) compra a } \\
\text { OGMA - Indústria Aeronáutica de Portugal S.A. }\end{array}$ \\
\hline 2005 & $\begin{array}{l}\text { - Lançamento das versões "Advanced Range" dos jatos EMBRAER } 190 \text { e EMBRAER } 195 \\
\text { (aviões de } 100 \text { e } 110 \text { assentos respectivamente), com aumento do alcance e flexibilidade } \\
\text { operacional. } \\
\text { - A "família" ERJ } 145 \text { atinge a marca de } 900 \text { aviões entregues. } \\
\text { - A Indústria Aeronáutica Neiva, entrega o milésimo avião Ipanema, sendo também a primeira } \\
\text { aeronave movida a álcool entregue a um cliente. } \\
\text { - Lançamento de jatos nas categorias "Very Light" e "Light" (Phenom } 100 \text { e Phenom 300, } \\
\text { respectivamente) para o mercado de aviação executiva. }\end{array}$ \\
\hline 2006 & $\begin{array}{l}\text { - Efetivação da reestruturação societária da Empresa, com a simplificação da estrutura do } \\
\text { capital social que passou a ser composto apenas por ações ordinárias, propiciando aumento da } \\
\text { liquidez a todos os acionistas e aprimoramento dos padrões de governança corporativa. } \\
\text { - Lançamento do Lineage } 1000 \text {, um jato executivo "ultra-large" baseado na plataforma do } \\
\text { avião comercial EMBRAER } 190 \text {. }\end{array}$ \\
\hline
\end{tabular}

Fontes: Embraer, 2006; Cassiolato et al, 2002. 
De acordo com Cassiolato et al (2002), após a privatização, a Embraer estabeleceu um plano de negócio baseado na obtenção de resultados financeiros através de uma profunda reestruturação organizacional e produtiva, e apoiado em uma estratégia diferenciada de mercado e de relacionamento com clientes e fornecedores.

O foco adotado pela nova administração caracterizou-se pela utilização de indicadores de desempenho, rentabilidade e satisfação dos clientes, e pelo monitoramento das mudanças e transformações futuras do mercado. Adicionalmente, a nova estratégia da empresa foi direcionada para a concentração em suas competências essenciais que agregassem valor e vantagens competitivas para a empresa.

O delineamento desta nova estratégia de mercado, de logística e de gestão da cadeia de suprimentos resultou na redução dos custos de produção e conseqüente aumento significativo da competitividade do produto final.

Atualmente, a Embraer é uma das maiores empresas aeronáuticas do mundo, já tendo produzido cerca de 3.900 aviões, que hoje operam em 65 países, nos cinco continentes. A empresa foi a maior exportadora brasileira entre os anos de 1999 e 2001, e foi a segunda maior empresa exportadora nos anos de 2002, 2003 e 2004, tendo apresentado uma receita líquida de 9.133,3 milhões de reais (3.830 milhões de dólares), em 2005, com as vendas externas representando $93,3 \%$ desse total. A composição dessa receita, em termos dos segmentos em que a empresa atua, teve a seguinte origem: $70,6 \%$ da aviação comercial (civil), $11 \%$ da aviação militar, $7,3 \%$ da aviação executiva e os restantes $11,1 \%$ de serviços. Sua força de trabalho totaliza mais de 17.000 empregados, sendo 85,9\% baseados no Brasil, e a empresa contribui ainda para a geração de mais de 5.000 empregos indiretos.

A Embraer é uma empresa global, com instalações em diversas partes do mundo, executando atividades de representação local, venda e comercialização de aeronaves, fabricação de componentes e conjuntos, montagem de aeronaves, manutenção e reparo, suporte técnico e material aos clientes, entre outras. O Quadro 9 apresenta uma descrição sucinta das unidades componentes do grupo Embraer. 
Quadro 9 - Composição do grupo Embraer

\section{Unidades industriais}

1. Embraer São José dos Campos: A unidade controladora está sediada no Brasil, em São José dos Campos, a $90 \mathrm{Km}$ da capital paulista. Essa unidade projeta, fabrica e dá suporte a aeronaves para os mercados de aviação comercial, executiva e de defesa. Tem $296.191 \mathrm{~m} 2$ de área construída e cerca de 11 mil funcionários.

2. Embraer Eugênio de Melo: Um terreno de $343.400 \mathrm{~m} 2$, com área construída de $54.607 \mathrm{~m} 2$, abriga as atividades de desenvolvimento e fabricação de ferramental, fabricação de tubos, solda e serralheria, e montagem de chicotes elétricos. Esta unidade, localizada no município de Eugênio de Melo, São Paulo, e conta com cerca de 1.200 funcionários.

3. Embraer Gavião Peixoto: Operando desde outubro de 2001, essa unidade abriga as atividades de montagem final de aeronaves destinadas aos mercados executivos e de defesa, tendo $44.413 \mathrm{~m} 2$ de área construída. Também conta com uma pista para ensaios em vôo. Localiza-se no município de Gavião Peixoto, São Paulo.

4. Embraer Botucatu: Instalada em Botucatu, São Paulo, tem $47.909 \mathrm{~m} 2$ de área construída e uma equipe de mais de 1.300 empregados. É responsável pela produção do avião Ipanema, fabricação de peças e estruturas para os jatos da empresa, montagem da fuselagem do ALX e fabricação de ferramental e dispositivos.

5. ELEB: Embraer Liebherr Equipamentos do Brasil S.A. é uma "joint venture" desde 1999 com o grupo Liebherr, originada da Embraer Divisão Equipamentos (EDE). Atua no fornecimento de sistemas de trem de pouso, equipamentos hidráulicos e eletromecânicos, com cerca de 600 funcionários.

6. Harbin Embraer: "Joint-venture" da Embraer com a empresa AVIC II, para a produção de aeronaves ERJ 145 em Harbin na China. Atua como montadora das aeronaves, não efetuando atividade de fabricação de partes.

\section{Escritórios regionais}

1. Embraer América do Norte: Subsidiária que comercializa e dá suporte pós-venda aos produtos Embraer, estando instalada em Fort Lauderdale, na Flórida/EUA.

2. Embraer Europa: Subsidiária instalada em Villepinte, Paris/França, atuando no armazenamento, vendas e gestão da logística e do reparo de componentes.

3. Embraer China: Escritório comercial em Beijin com atuação voltada para comercialização de aeronaves e suporte pós-venda.

4. Embraer Cingapura: Escritório comercial com atuação voltada para comercialização de aeronaves e suporte pós-venda para o mercado Ásia Pacífico.

\section{Centros de suporte ao cliente}

1. EAMS: Embraer Aircraft Maintenance Services, localizada em Nashville, Tennessee/EUA, oferece serviços de manutenção de aeronaves, reparo de componentes, suporte técnico e gestão logística e de estoque.

2. OGMA: Indústria Aeronáutica de Portugal S.A., localizada em Alverca, oferece serviços de manutenção de aeronaves e motores, reparo e testes de componentes eletromecânicos, além de fabricação de peças e montagem de estrutura.

Fonte: Preparado pelo autor.

A empresa mantém uma ampla gama de produtos, conforme mostrado no Quadro 10, distribuída pelas diversas fases do ciclo de vida de uma aeronave (ver Anexo 5), atendendo aos segmentos comercial (civil) e militar e a várias faixas de mercado, como resultado de sua 
ação empresarial para garantir alinhamento com as necessidades e expectativas dos clientes, e assegurar seu crescimento e longevidade.

\section{Quadro 10 - Aeronaves da Embraer}

\section{Mercado civil}

1. EMB 120: Turboélice pressurizado para 30 passageiros e uso em linhas aéreas regionais, o "Brasília" tem velocidade máxima de $583 \mathrm{~km} / \mathrm{h}$ e alcance de $1.482 \mathrm{~km}$.

2. ERJ 135: Jato regional para 37 passageiros, versão compacta do ERJ 145. Atinge velocidade máxima de 0,78 mach e alcance de $3.241 \mathrm{~km}$.

3. ERJ 140: Jato regional para 44 passageiros, seguindo o conceito de "família 145". Alcance de $3.056 \mathrm{~km}$ com a mesma velocidade do ERJ 135.

4. ERJ 145: Primeiro membro lançado da "família" de jatos regionais, com 50 assentos e um alcance de $2.871 \mathrm{~km}$, a uma velocidade máxima de $0,78 \mathrm{mach}$.

5. ERJ 145 XR: Versão de longo alcance da aeronave de 50 assentos $(3.704 \mathrm{~km})$, atingindo velocidade máxima de 0,80 mach.

6. Legacy 600: Jato executivo desenvolvido com base na plataforma do ERJ 135 para até 16 passageiros, com variada opção de interior customizado.

7. Legacy Shuttle: Derivação do Legacy 600 para até 19 passageiros, interior mais padronizado e com versatilidade para estender até 37 assentos.

8. EMB 170: Jato regional para 70 a 78 passageiros, podendo atingir velocidade máxima de 0,82 mach com um alcance de $3.704 \mathrm{~km}$, desenvolvido com tecnologia de última geração.

9. EMB 175: Segundo componente da "família 170", cobrindo a faixa de 78 a 86 assentos, com a mesma velocidade e um alcance de $3.334 \mathrm{~km}$.

10. EMB 190: Jato regional para 98 a 106 passageiros, com alcance de $4.260 \mathrm{~km}$ a uma velocidade máxima de 0,82 mach.

11. EMB 195: Maior membro da "família" de jatos regionais, com 108 a 118 assentos e alcance de $3.889 \mathrm{~km}$ a uma velocidade de 0,82 mach.

12. Lineage 1000: Jato executivo do segmento "ultra-large" para até 19 passageiros e com diversas opções de configuração do interior, em desenvolvimento a partir da plataforma do EMB 190.

13. Phenom: Família de jatos executivos em fase de desenvolvimento para atender aos segmentos "very light" e "light", com capacidade para até 9 passageiros.

14. Ipanema: Avião agrícola monoposto impulsionado por conjunto motopropulsor (motor e hélice) à gasolina ou à álcool, utilizado para pulverização de lavouras.

\section{Mercado militar}

1. EMB 312 "Tucano": Aeronave turboélice de treinamento militar e líder mundial no seu segmento de mercado.

2. Super Tucano "ALX": Aeronave militar de treinamento e aplicações operacionais de vigilância de fronteiras e espaço aéreo, derivado do EMB 312.

3. AMX-T: Jato de ataque subsônico militar, para missões táticas, desenvolvido em consórcio com a Aeritalia.

4. EMB 145 AEW\&C: Aeronave de vigilância e reconhecimento de áreas desenvolvido sobre a plataforma do ERJ 145.

5. EMB 145 RS/AGS: Aeronave de sensoriamento remoto do solo, com imagens geradas em tempo real, baseada na plataforma do jato ERJ 145.

6. P-99: Aeronave de patrulha marítima e defesa da costa derivada do jato ERJ145.

Fonte: Preparado pelo autor. 
A vantagem competitiva que tem sido demonstrada pela Embraer reside em sua capacidade de inovação em produtos e processos, e em sua habilidade de identificar e atender as necessidades e expectativas dos clientes.

Esta capacidade de inovação tem sido evidenciada, ao longo do tempo, através de produtos compatíveis com o estado da arte da tecnologia aeronáutica e com os requisitos de mercado vigentes quando do lançamento dos mesmos, e através de processos e tecnologias alinhados com as melhores práticas mundiais, conforme pode ser visto no Quadro 11.

Quadro 11 - Evolução das tecnologias de produto e processo

\begin{tabular}{|c|c|c|}
\hline$\frac{\text { Anos } 80}{\text { EMB } 120}$ & $\begin{array}{r}\text { Anos 90 } \\
\text { Família ERJ } 145\end{array}$ & $\begin{array}{c}\text { Anos 00 } \\
\text { Famila 170/190 }\end{array}$ \\
\hline $\begin{array}{l}\text { Cadeia produtiva } \\
\text { verticalizada }\end{array}$ & $\begin{array}{l}\text { Subcontratação de componentes } \\
\text { e processos; parceria de risco }\end{array}$ & $\begin{array}{l}\text { Adensamento e aumento da } \\
\text { subcontratação; parceria de } \\
\text { risco }\end{array}$ \\
\hline Projeto tradicional & $\begin{array}{l}\text { Engenharia simultânea com } \\
\text { conecção em tempo real }\end{array}$ & $\begin{array}{l}\text { Engenharia cooperativa com } \\
\text { co-localização }\end{array}$ \\
\hline $\begin{array}{l}\text { "Mock-up" tradicional - } \\
\text { modelo em madeira }\end{array}$ & $\begin{array}{l}\text { "Mock-up" eletrônico - imagem } \\
\text { tridimensional em CAD/CAM }\end{array}$ & $\begin{array}{l}\text { "Mock-up" digital - tecnologia } \\
\text { de realidade virtual; simulador } \\
\text { de vôo }\end{array}$ \\
\hline $\begin{array}{l}\text { Instrumentos de vôo } \\
\text { eletrônicos }\end{array}$ & Painel totalmente digital & $\begin{array}{l}\text { "Fly-by-wire" - controle de } \\
\text { vôo por comandos eletrônicos }\end{array}$ \\
\hline Motor turboélice & Motor turbofan (jato) & $\begin{array}{l}\text { Motor turbofan e sistemas } \\
\text { integrados eletronicamente }\end{array}$ \\
\hline Fuselagem tradicional & Fuselagem tradicional & $\begin{array}{l}\text { "Double bubble" - seção } \\
\text { transversal de formato duplo }\end{array}$ \\
\hline $\begin{array}{l}\text { Montagem em linha - } \\
\text { baixa cadência ( } 2 \text { av./mês) }\end{array}$ & $\begin{array}{l}\text { Montagem em linha - alta } \\
\text { cadência ( } 16 \text { av./mês) }\end{array}$ & Montagem em docas \\
\hline $\begin{array}{l}\text { Gestão tradicional da } \\
\text { manufatura }\end{array}$ & $\begin{array}{l}\text { Qualidade total, Kaizen, Célula } \\
\text { de manufatura, } 5 \mathrm{~S} \text {, produção } \\
\text { enxuta ("lean") }\end{array}$ & $\begin{array}{l}\text { Qualidade total, Kaizen, 5S, } \\
\text { Célula de manufatura, } \\
\text { produção enxuta ("lean") }\end{array}$ \\
\hline $\begin{array}{l}\text { Processos convencionais } \\
\text { de produção }\end{array}$ & $\begin{array}{l}\text { Automação na fabricação de } \\
\text { peças }\end{array}$ & $\begin{array}{l}\text { Automação na fabricação de } \\
\text { peças e montagem }\end{array}$ \\
\hline $\begin{array}{l}\text { Controle de estoque } \\
\text { tradicional }\end{array}$ & $\begin{array}{l}\text { Identificação por código de } \\
\text { barras }\end{array}$ & $\begin{array}{l}\text { Identificação por código de } \\
\text { barras }\end{array}$ \\
\hline
\end{tabular}

Fonte: Preparado pelo autor.

Adicionalmente, Cassiolato et al (2002) afirmam que a competência central da empresa está na sua capacidade de projetar, desenvolver e especificar o produto, na difícil e complexa 
tarefa de integrar os diversos componentes e sistemas de forma harmoniosa na fuselagem da aeronave, e na assistência técnica pós-venda.

A empresa tem buscado direcionar suas atividades para atuar como integradora de sistemas, o que tem levado a um processo de desintegração vertical, ou seja, a transferência de atividades de manufatura aos fornecedores (outsourcing), com o compartilhamento de riscos, incentivos e benefícios.

De acordo com Giunta (1999), a redução do grau de integração vertical e consequiente aumento do outsourcing passaram a ser uma característica presente na indústria aeronáutica devido a três impulsionadores:

1) A variedade de tecnologias presentes em uma aeronave, o que leva a uma participação de várias empresas especializadas;

2) A redução de custo e o alinhamento estratégico da produção;

3) Os acordos de compensação (offset) como parte da política industrial de governos que objetivam desenvolver a indústria aeronáutica do país.

A forma como está organizada esta estrutura de outsourcing na Embraer é abordada no tópico seguinte.

\subsubsection{A cadeia de suprimentos da Embraer}

De acordo com Cassiolato et al (2002), a Embraer detém os ativos estratégicos que lhe permitem exercer o poder de comando e coordenar sua cadeia produtiva local e global e sua rede de fornecimento.

A cadeia de suprimentos da Embraer apresenta uma estrutura hierárquica bem definida, em consonância com o modelo apresentado no item 4.1.2 anterior.

A Embraer ocupa a primeira camada, atuando como empresa líder.

Na segunda camada estão os parceiros de risco, definidos como aqueles fornecedores que assumem riscos financeiros na fase de desenvolvimento dos projetos. Estes parceiros são grandes empresas internacionais que participam no desenvolvimento conjunto do produto e no 
estabelecimento das especificações técnicas, e agregam tecnologia, sendo responsáveis pelo fornecimento de sistemas e submontagens completas (motores, aviônica, fuselagem), que serão integrados na montagem final da aeronave pela Embraer.

$\mathrm{Na}$ terceira camada aparecem os fornecedores de componentes e conjuntos específicos (eletrônicos, hidráulicos e pneumáticos) que atuam com base nas especificações técnicas definidas pela Embraer e/ou parceiros de risco.

Na quarta camada estão os fornecedores de matéria-prima (chapas, placas, forjados), de elementos de fixação e montagem (parafusos, porcas, rebites) e de componentes elétricos (fios, cabos, conectores, pinos). Neste nível também atuam os subcontratados - empresas de pequeno porte que recebem matéria prima e desenho técnico da Embraer para executar atividades de usinagem, tratamentos químicos e térmicos, acabamento superficial e montagens de subconjuntos.

A composição relativa das classes de suprimentos, sob o ponto de vista econômico, para a produção de aeronaves é formada por $60 \%$ de equipamentos (motores, aviônicos, sistemas hidráulicos, etc), $34 \%$ de estruturas metálicas (fuselagem, asas, naceles, etc) e $6 \%$ de componentes mecânicos, elétricos e matéria-prima, sendo $95 \%$ oriundos de empresas localizadas no exterior.

A gestão da cadeia de suprimentos e a formulação da estratégia de relacionamento com os fornecedores são feitas pela Diretoria de Suprimentos, vinculada à Vice-Presidência de Operações, atuando através de uma estrutura funcional conforme esquematizado na Figura 9.

Os Gerentes de Suprimentos de nível sênior participam na definição das estratégias de gestão da cadeia de suprimentos e de seus relacionamentos, englobando aspectos comerciais, técnicos, logísticos, de qualidade e de suporte pós-venda, e são responsáveis pela implantação destas estratégias dentro do grupo de parceiros e fornecedores pertencentes à tecnologia pela qual respondem. 


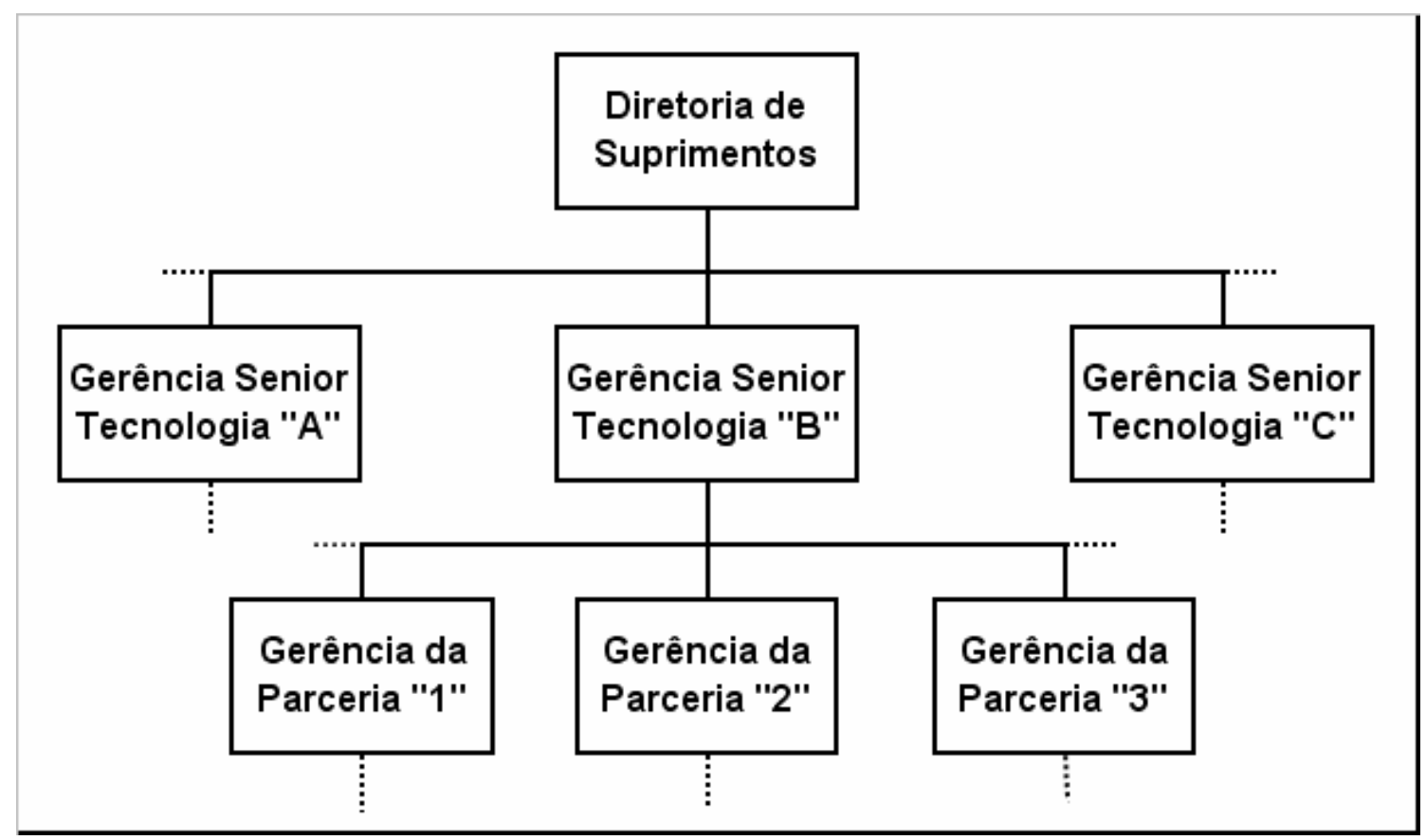

Figura 9 - Estrutura Organizacional de Suprimentos da Embraer Fontes: Preparada pelo autor.

Os Gerentes de Suprimentos da Parceria são responsáveis pela implementação das estratégias e administração do dia-a-dia do fornecedor, através da coordenação de uma equipe de profissionais de suprimentos. A atuação desses gerentes abrange todos os aspectos da interação entre a Embraer e o fornecedor - novos desenvolvimentos, produção em série e suporte pós-venda, coordenando o relacionamento entre variados setores organizacionais de ambas as empresas nos diversos níveis hierárquicos, agindo como elo entre as partes e tendo a responsabilidade de acompanhar e garantir o desempenho do fornecedor.

O relacionamento entre a empresa e os fornecedores é detalhado no tópico seguinte.

\subsubsection{Relacionamento da Embraer com fornecedores}

De acordo com Cassiolato et al (2002), após a privatização, a Embraer estabeleceu um plano de ação cuja prioridade máxima era viabilizar o projeto ERJ-145 e incluía a construção de um novo modelo de relacionamento com os fornecedores, baseado em parceria. A idéia básica por trás deste modelo era dividir os altos riscos associados ao desenvolvimento de um projeto desse porte e ao padrão de competição do setor. 
A Figura 10 mostra como evoluiu este modelo de relacionamento na Embraer, associado ao crescimento da complexidade e dos riscos dos projetos desenvolvidos pela empresa a partir da privatização.

Apesar da similaridade de conceitos existente, os projetos ERJ-145 e EMB-170/190 representam duas abordagens diferentes. O primeiro pode ser caracterizado como tendo um grande foco em custos, enquanto o projeto EMB-170/190 apresenta como fator essencial a agregação de valor e tecnologia (CASSIOLATO et al, 2002).

Nos tópicos a seguir, ambos os projetos são apresentados de forma mais detalhada.

\subsubsection{O projeto ERJ-145}

Este projeto foi iniciado em 1989, quando a empresa ainda era uma estatal. No entanto, sua viabilidade financeira só deu-se após a privatização, quando a empresa adquiriu flexibilidade e agilidade empresariais, e com o estabelecimento de parcerias de risco.

De acordo com Cassiolato et al (2002), a Embraer foi capaz de atrair parceiros para investir no projeto ERJ-145 porque a empresa tinha capacidade tecnológica e de projeto reconhecidas no mercado.

O projeto foi baseado na idéia de partilhar riscos entre os parceiros e no comprometimento de cada participante em desenvolver um subsistema da aeronave - mais especificamente componentes estruturais e de interior, garantindo o financiamento do projeto e diluindo o risco das incertezas de mercado.

Atualmente, os custos crescentes e os longos ciclos associados ao desenvolvimento de aeronaves, assim como as incertezas e o longo prazo para retorno dos investimentos, fizeram com que este tipo de arranjo se tornasse uma regra de sobrevivência neste setor (CASSIOLATO et al, 2002). 


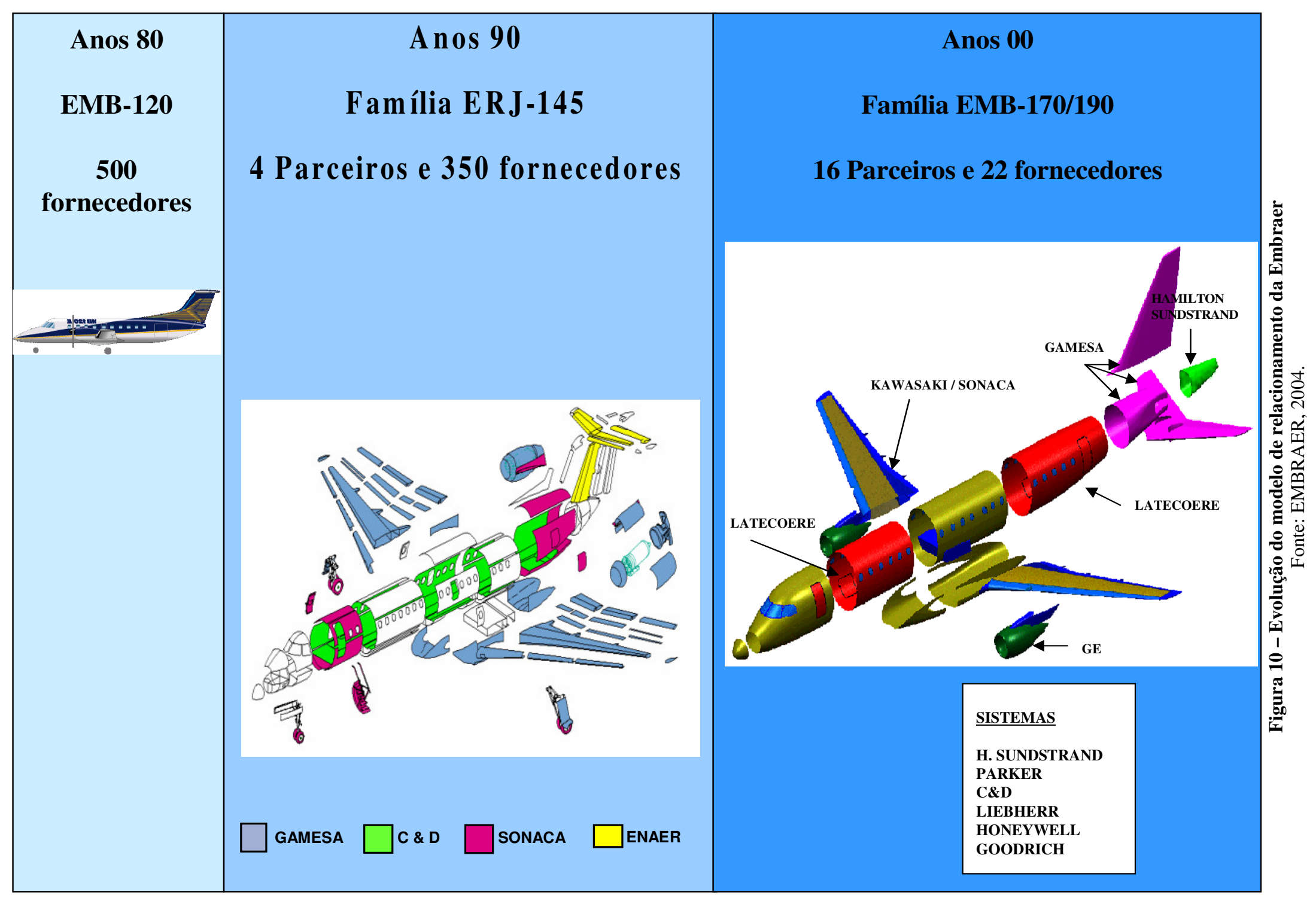


O projeto adotou o conceito de "família de jatos" que permitiu à Embraer obter os benefícios derivados do desenvolvimento de várias versões de aeronaves a partir de um mesmo modelo básico - redução de custos e de ciclos de desenvolvimento e produção. Desta forma, a empresa disponibilizou produtos numa faixa de mercado entre 37 e 50 assentos, com os modelos ERJ-135, ERJ-140 e ERJ-145 (ver Quadro 10), atendendo a diferentes necessidades dos clientes.

O investimento necessário para o desenvolvimento do projeto ERJ-145 era de US\$ 350 milhões e as dificuldades financeiras e falta de crédito da Embraer eram um grande obstáculo a ser superado. A solução foi identificar empresas internacionais interessadas em investir no projeto e adquirir tecnologia aeronáutica da Embraer, assumindo a responsabilidade por fabricar subsistemas da aeronave, tendo como retorno a partilha dos lucros obtidos com as vendas futuras. Os parceiros de risco participaram com US\$100 milhões no investimento total previsto, tendo o BNDES $^{6}$ financiado outra parcela equivalente a esta.

Os parceiros selecionados foram: Gamesa da Espanha, responsável pelas asas, naceles dos motores, carenagem asa-fuselagem e porta do trem de pouso principal; Enaer do Chile, produzindo estabilizadores vertical e horizontal e leme; Sonaca da Bélgica, fornecendo fuselagens dianteira e traseira, pilones dos motores, portas principais, de serviço e do bagageiro; C\&D dos Estados Unidos, desenvolvendo interiores da cabine e compartimento de carga, conforme mostrado na Figura 10. O critério de seleção levou em conta que estas empresas tinham disponibilidade de capital e disposição de investir a risco no projeto.

No aspecto de capacitação técnica e tecnologia, as empresas encontravam-se em estágios diferentes: desde nenhuma experiência anterior em indústria aeronáutica - Gamesa, até participante importante em projetos de aeronaves - C\&D.

O resultado comercial alcançado por este projeto foi significativamente superior àquele previsto inicialmente no plano de negócio, quando do seu lançamento. Considerando os resultados publicados pela empresa, referentes ao $3^{\circ}$ trimestre de 2006 , a carteira de pedidos da "família" ERJ-145 atingiu um total de 1.047 aeronaves vendidas, sendo 859 entregues.

\footnotetext{
${ }^{6}$ Banco Nacional de Desenvolvimento Econômico e Social
} 
De acordo com Cassiolato et al (2002), algumas habilidades importantes foram adquiridas pela Embraer com este projeto: coordenação de redes de negócio, gestão de contratos complexos, gestão do fluxo de partes e componentes, e controle de ciclos e qualidade do produto.

O maior aprendizado para a empresa foi o entendimento do modelo de parceria e a capacitação para a gestão deste tipo de relacionamento na cadeia de suprimentos, o que foi fundamental para a evolução e aprofundamento do modelo no projeto EMBRAER 170/190.

\subsubsection{O projeto EMBRAER 170/190}

A principal diferença deste projeto comparado com o ERJ-145 foi a maior integração e sofisticação dos parceiros. O projeto foi desenvolvido em conjunto com as empresas parceiras, as quais se responsabilizaram pelas especificações técnicas e detalhamento do projeto dos subsistemas que deveriam fornecer. A Embraer foi responsável pela definição dos requisitos de alto nível do produto - objetivos de desempenho, peso e preço, pela execução de uma parcela do desenho do projeto, pela integração de todos os sistemas, pela estrutura e montagem final da aeronave.

O desenvolvimento desta família de jatos regionais requereu investimentos de US\$ 850 milhões e foi necessário buscar uma participação mais ampla de empresas e instituições financeiras internacionais capazes de financiar o projeto. A escolha de parceiros internacionais objetivou assegurar a agregação de tecnologia ao projeto para atender a três requisitos de alto nível: treinamento técnico, capacidade de fornecimento e integração dos pacotes tecnológicos, bem como garantir uma completa estrutura financeira e de investimento.

O projeto manteve o conceito de "família de jatos", disponibilizando produtos para os segmentos de mercado entre 70 e 118 assentos, com os modelos EMB-170, EMB-175, EMB190 e EMB-195, conforme apresentado no Quadro 10.

O desenvolvimento do projeto foi precedido de uma pesquisa detalhada envolvendo inteligência de mercado e abrangendo as seguintes atividades: 
1) Estudo de dados históricos = observação e análise do comportamento e evolução da demanda de mercado e desempenho de projetos anteriores;

2) Análise de tendências de mercado = quantificação da demanda global por aeronaves, avaliando tamanho, idade e condições das frotas existentes, número de aeronaves em operação, carteira de pedidos, unidades vendidas e previsão de vendas;

3) Identificação das necessidades específicas dos clientes potenciais = abordagem direta dos clientes em diversos níveis - empresas aéreas, tripulação, técnicos de operação e manutenção e passageiros, coletando os principais requisitos operacionais e características funcionais desejadas.

A pesquisa permitiu constatar alguns fatos relevantes:

- Havia uma crescente dificuldade em otimizar a relação capacidade e demanda com as aeronaves existentes, devido à evolução contínua dos mercados regionais;

- A necessidade de aumentar a freqüência de vôos nas rotas regionais (estratégia fundamental para garantir participação de mercado) estava levando os operadores a utilizar aviões com muita capacidade (acima de 120 assentos) em rotas de menor demanda;

- Os jatos regionais (até 50 assentos) estavam, muito frequentemente, operando no limite de sua capacidade;

- O envelhecimento da frota de aviões comerciais estava impactando a rentabilidade das empresas aéreas em função do aumento do consumo de combustível e dos custos de manutenção;

- Os clientes estavam tornando-se cada vez mais exigentes quanto aos padrões de desempenho das aeronaves e quanto ao conforto oferecido aos passageiros.

O resultado final desta pesquisa foi a constatação de que havia um "gap" de aeronaves para a faixa de 70 a 120 assentos que permitisse otimizar a operação das empresas aéreas - adequar a frota à demanda de mercado para maximizar lucros, e de que havia real interesse dos clientes por um novo produto. Além disso, obtiveram-se as características e os requisitos esperados das aeronaves para este segmento.

O projeto foi organizado em três fases:

1) Definição inicial - envolveu a concepção da aeronave. O plano de negócio foi preparado contendo requisitos do mercado, características do produto, plano de custos, 
investimentos necessários, ciclo de vida do produto, análise de risco e retorno do investimento, identificação de nicho.

2) Definição conjunta - caracterizou-se pela divisão da aeronave em subsistemas e alocação do trabalho entre os parceiros selecionados, com o estabelecimento dos parâmetros da aeronave em conjunto pela Embraer e os parceiros. A Embraer e os parceiros designaram técnicos e engenheiros com dedicação integral ao projeto, trabalhando em equipes multidisciplinares nas instalações da Embraer no Brasil, conectadas em rede com as plantas e laboratórios das diversas empresas. Esta estratégia, associada à utilização de sofisticada tecnologia de informação - troca eletrônica de dados, centro de realidade virtual, simulador de vôo, "mock-up" digital, permitiu o desenvolvimento integrado do produto e ganhos significativos de qualidade, além da redução em 18 meses no ciclo de desenvolvimento da aeronave (de 54 para 36 meses).

3) Projeto detalhado e certificação - definição final da aeronave, detalhamento dos sistemas pelos parceiros, construção dos protótipos, testes de vôo e certificação do produto.

O estabelecimento do relacionamento de parceria neste projeto teve um grau de complexidade muito maior do que na experiência anterior com o ERJ-145. Isto ocorreu em função dos desafios tecnológicos impostos pelo produto a ser desenvolvido, da amplitude do escopo do projeto a ser absorvido por cada parceiro e da abrangência das atividades e tarefas sob responsabilidade de cada parceiro, além do número de parceiros envolvidos.

Na Figura 10 são apresentados os parceiros responsáveis pelos principais sistemas das aeronaves EMB-170/190, os quais são descritos de forma sucinta a seguir:

- GE (Estados Unidos) - sistema de propulsão (motores e naceles);

- Honeywell (Estados Unidos) - sistema aviônico e de iluminação;

- Gamesa (Espanha) - fuselagem e empenagem traseira;

- Hamilton Sundstrand (Estados Unidos) - sistema elétrico, sistema ambiental e sistema auxiliar de potência;

- Kawasaki (Japão) - estrutura central das asas, superfícies de controle e pilones dos motores;

- Liebherr (Alemanha) - sistema de trem de pouso;

- Sonaca (Bélgica) - fuselagem central II e slats;

- Latécoère (França) - fuselagens centrais I e II e portas; 
- Parker (Estados Unidos) - sistema de controle de vôo, sistema de combustível e sistema hidráulico;

- $\quad \mathrm{C} \& \mathrm{D}$ (Estados Unidos) - interiores da cabine e compartimento de carga;

- BFGoodrich (Estados Unidos) - sistema anemométrico e limpador de pára-brisa.

Os dezesseis parceiros citados na Figura 10 consolidam-se nas onze corporações acima. O processo de seleção dos parceiros foi efetuado, de forma independente, por pacotes tecnológicos componentes da aeronave. Após a finalização deste processo, algumas empresas selecionadas pertenciam a uma mesma corporação, o que resultou nesta consolidação e na conseqüente evolução do relacionamento para uma abordagem corporativa.

De acordo com Cassiolato et al (2002), as capacidades de desenvolvimento de novas tecnologias e de investimento tiveram maior ênfase entre os fatores considerados na seleção dos parceiros para o projeto EMB-170/190.

O presente trabalho de pesquisa desenvolveu um estudo de caso para avaliar o relacionamento entre a Embraer e os parceiros do projeto EMB-170/190, tendo como referência o modelo apresentado no tópico 2.2 e mostrado na Figura 4. Para tanto, foram coletadas informações com as pessoas-chaves da estrutura organizacional de suprimentos da empresa - Gerência Sênior e Gerência da Parceria (ver Figura 9), através de entrevistas e questionários estruturados de coleta de dados.

Este capítulo caracterizou o ambiente no qual se desenvolveu o relacionamento de parceria da Embraer com alguns de seus fornecedores. Definiu as fronteiras do estudo de caso e especificou as fontes e formas de obtenção das informações utilizadas para efetuar a verificação da teoria e do modelo apresentados anteriormente, neste contexto específico.

No capítulo a seguir são abordadas de forma detalhada as informações e os resultados obtidos. 


\section{ANÁLISE DE DADOS E RESULTADOS}

Este capítulo apresenta os resultados obtidos através dos dados coletados durante o estudo de caso. Inicialmente são detalhados os aspectos gerais da parceria por meio de descrição narrativa das informações colhidas nas entrevistas realizadas com os Gerentes de Suprimentos de nível sênior, enriquecidos com citações de excertos registrados durante o processo. Em seguida são detalhadas as características específicas da parceria com base nos dados obtidos através do questionário estruturado aplicado aos Gerentes de Parceria. Para concluir o capítulo, é feita uma análise, por método comparativo, dos dados, informações e resultados obtidos, tendo como referência a fundamentação teórica desenvolvida para esta pesquisa.

\subsection{Apresentação dos dados e informações coletadas}

Conforme detalhado no Capítulo 3, a metodologia utilizada para obtenção das informações e dos dados sobre o relacionamento de parceria da Embraer com os fornecedores do projeto EMB-170/190 consistiu na abordagem aos informantes chaves de nível gerencial da empresa.

Esta abordagem foi efetuada através de dois instrumentos distintos de pesquisa - entrevista pessoal e questionário estruturado, cada qual aplicado a um grupo diferente de profissionais, em função do conhecimento e experiência dos referidos Gerentes quanto ao relacionamento de parceria em questão e do tipo de informação que se pretendia obter - aspectos gerais e características específicas.

A seguir, as informações coletadas são apresentadas em tópicos distintos.

\subsubsection{Aspectos gerais da parceria}

Com base em um instrumento de coleta de informações utilizado como roteiro, foram realizadas quatro entrevistas com Gerentes de Suprimentos de nível sênior (ver Figura 9, no Capítulo 4), com o objetivo de caracterizar os aspectos gerais e estratégicos da parceria do fabricante com os fornecedores e obter uma avaliação qualitativa sobre a mesma. 
Os Gerentes entrevistados atuavam, na época da entrevista, há pelo menos sete anos na Embraer, tendo uma experiência profissional superior a dez anos na área de suprimentos e com um mínimo de três anos dedicados ao projeto EMB-170/190, com envolvimento nas fases de seleção de fornecedores, desenvolvimento do produto e produção em série. Considerando a ação conjunta destes profissionais, houve uma representatividade abrangente do espectro de parceiros envolvidos.

O primeiro aspecto abordado diz respeito ao entendimento do conceito de parceria e sua abrangência no âmbito do projeto EMB-170/190, o qual é objeto de estudo desta pesquisa.

A parceria com os fornecedores neste âmbito é entendida, pelos entrevistados, como uma relação entre empresas para viabilizar o desenvolvimento do produto, com a partilha dos riscos associados. Engloba uma divisão de trabalho claramente definida, com as atividades de detalhamento do projeto ficando sob a responsabilidade dos fornecedores.

“... associação técnica entre empresas, onde cada uma buscava alcançar seus objetivos no desenvolvimento conjunto do programa."

A abrangência da parceria envolveu desenvolvimento do produto - aspectos técnicos e tecnológicos, e finanças - investimento e absorção de custos de desenvolvimento.

Um outro aspecto importante diz respeito à caracterização dos objetivos pretendidos com o estabelecimento da relação de parceria.

Neste sentido, as informações coletadas evidenciaram os seguintes objetivos principais:

- Viabilizar financeiramente o projeto;

- Reduzir significativamente o tempo para desenvolvimento do produto;

- Assegurar o estado da arte em tecnologia;

- Compartilhar recursos e riscos;

- Atingir custo competitivo para o produto final.

Em função do investimento de capital necessário, era fundamental que os fornecedores contribuíssem financeiramente com parte do valor total orçado para o desenvolvimento do 
projeto. Adicionalmente, havia a necessidade de disponibilizar o produto para o mercado em um espaço de tempo menor possível, como forma de ocupar o "gap" constatado para aeronaves na faixa de 70 a 120 assentos, antes da concorrência.

Para atingir esses objetivos, o processo tradicional em que a Embraer elaborava o projeto completo e contratava centenas de fornecedores para fabricar os componentes especificados precisava ser alterado, o que significava a redução do número de fornecedores com o estabelecimento de um relacionamento muito próximo e diferenciado, a ampliação do escopo de fornecimento e o compartilhamento de pessoal técnico para desenvolvimento conjunto e de forma simultânea do projeto.

Como objetivos complementares vale destacar: expandir relações com outros continentes, como forma de alavancar a abertura de futuros mercados, e buscar fornecedores em outros nichos de mercado, como meio de ampliar opções e melhorar a competitividade.

Em consonância com os objetivos estabelecidos, as entrevistas revelaram que os critérios de seleção dos fornecedores foram mais amplos do que os tradicionais - preço, qualidade, capacidade de atender às especificações, suporte pós-venda, e englobaram:

- Aporte financeiro oferecido para participar do projeto;

- Capacidade de investimento para o desenvolvimento do produto;

- Capacitação técnica e tecnológica para atender ao escopo ampliado de fornecimento;

- Experiência anterior com integração de sistemas em outros projetos.

Aspectos subjetivos como proximidade entre as culturas empresariais das empresas, relacionamentos anteriores e existência de relação atual em outros projetos, também foram relatados como fatores presentes no processo de escolha dos parceiros.

"O fator subjetivo que representa a facilidade de fazer negócio com determinada empresa, baseado em experiências anteriores ou nos contatos durante a concorrência, também foi considerado."

Embora não totalmente incongruentes, a conciliação entre a busca por expansão das relações com outros continentes através da parceria e por proximidade entre as culturas empresariais, torna-se de difícil implantação na prática, merecendo cuidados específicos. 
Uma consequiência imediata da decisão de escolha de um parceiro é a formalização do acordo para o projeto. As empresas negociam um contrato jurídico detalhado e complexo, compreendendo aspectos econômico-financeiros, comerciais, técnicos, logísticos, temporais e operacionais, baseado na proposta final vencedora da concorrência realizada e nos requisitos estabelecidos no plano de negócio. Este contrato norteará o relacionamento entre as empresas durante toda a vida do projeto, abrangendo as fases de desenvolvimento, produção em série e suporte pós-venda.

Como uma parte da gama de materiais comprados para a aeronave não é coberta pelos parceiros, esta lacuna é suprida por fornecedores complementares. Portanto, a compreensão dos aspectos que distinguem estas entidades é um fator interessante a ser explorado.

De acordo com os entrevistados, as diferenças entre "parceiro" e "fornecedor" estão nos seguintes pontos:

- Aporte financeiro no projeto = requerido apenas dos parceiros;

- $\quad$ Risco assumido = obrigação da Embraer em caso de insucesso do projeto está restrita aos fornecedores;

- Escopo da responsabilidade = parceiro responde pelo desenvolvimento técnico completo do subsistema a fornecer, enquanto fornecedor responde pelo atendimento à especificação recebida;

- Grau de integração = informações e detalhes do projeto têm amplitudes e profundidades abrangentes no que diz respeito aos parceiros, sendo básicas para os fornecedores.

Por outro lado, aspectos como qualidade do produto, custos e atendimento a prazos apresentam o mesmo grau de exigência quanto às metas a atingir tanto para os parceiros como para os fornecedores.

A Embraer desenvolveu o relacionamento de parceria para o projeto EMB-170/190 baseado na experiência adquirida com o modelo implementado para o projeto ERJ-145. Esta experiência anterior trouxe capacitação e entendimento quanto a este tipo de relacionamento com a cadeia de suprimentos. No entanto, o estabelecimento do relacionamento de parceria no projeto EMB-170/190 teve um grau de complexidade muito maior levando em consideração as diferenças existentes quanto ao produto em si - desafios tecnológicos superiores; quanto ao 
escopo de fornecimento - abrangência mais ampla, e quanto ao número de parceiros envolvidos - quatro vezes maior.

As entrevistas permitiram relacionar as seguintes diferenças entre as parcerias estabelecidas em cada um dos projetos:

- $\quad$ Aporte financeiro = mais amplo no EMB-170/190;

- Especificação técnica dos materiais = pelo parceiro no EMB-170/190 x pela Embraer no ERJ-145;

- $\quad$ Processo de desenvolvimento do projeto = conjunto no EMB-170/190 x pela Embraer no ERJ-145;

- Materiais abrangidos = no EMB-170/190 foram incluídos equipamentos e sistemas, além da estrutura e do interior que fizeram parte do ERJ-145.

"O programa 0145 foi integralmente desenvolvido pela Embraer e o conceito de parceiros foi utilizado para aqueles fornecedores que decidiram investir na produção dos aviões."

Até este ponto, as informações permitiram caracterizar a parceria do projeto EMB-170/190, explicitando os aspectos de conceituação, abrangência, objetivos e critérios de seleção, bem como as diferenças em relação ao projeto ERJ-145 e ao relacionamento tradicional com fornecedores. O passo seguinte envolve uma avaliação qualitativa da parceria, considerando o estágio atual do relacionamento e do projeto.

Os entrevistados consideram que a parceria do projeto EMB-170/190 foi bem sucedida, pois os objetivos do desenvolvimento do produto foram atendidos - viabilização do projeto nas diversas dimensões previstas (financeira, econômica, técnica, temporal).

A organização funcional do projeto - gerenciamento por um “core team” formado por todas as áreas envolvidas e equipes técnico-operacionais co-localizadas, e a fase de definição conjunta das especificações realizada na Embraer com a presença das equipes técnicas de todos os parceiros foram consideradas decisivas para este sucesso.

Adicionalmente, há o sucesso comercial alcançado pelo produto no mercado, com a carteira de pedidos tendo acumulado um total de 964 aeronaves vendidas - 184 entregues, 359 ordens firmes e 421 opções (ordens passíveis de confirmação), no $3^{\circ}$ trimestre de 2006. Este volume 
total já supera o que foi originalmente previsto no plano de negócio em 2000 para ser atingido em 10 anos.

"Se considerarmos como objetivo da parceria o desenvolvimento do produto, a carteira de pedidos, o crescimento vertiginoso do volume de produção a níveis jamais pensados, e as características do produto em conformidade com os parâmetros do projeto, são provas que a parceria foi um sucesso."

Por outro lado, as entrevistas permitiram captar que a visão da parceria foi focada excessivamente na fase de desenvolvimento do produto, quando deveria ter tido uma abordagem mais ampla, considerando o negócio como um todo. A transição para a produção em série não foi adequada, pois ocorreu de forma abrupta entre a organização funcional do projeto e a organização hierárquica de operações, em termos de descontinuidade das pessoas e de processos não estabilizados.

Esta constatação apóia-se também na deficiência observada quanto ao atendimento da demanda para a produção em série, mesmo considerando a atenuante representada pelo fato de que o cenário que se efetivou foi muito além das previsões otimistas.

"Como decorrência de dificuldades verificadas no aumento da cadência de produção das aeronaves EMBRAER 190 e EMBRAER 195, especialmente em relação à montagem das asas e a atrasos na cadeia de suprimentos, a Embraer revisou sua previsão de entregas para 135 aeronaves em 2006, em comparação com as 145 estimadas anteriormente." 7

A visão focalizada da parceria conduziu a negociações comerciais extremamente difíceis, relativas a reivindicações surgidas durante a fase de desenvolvimento, provocando um desgaste significativo no relacionamento entre as partes.

Este desgaste foi potencializado na fase de produção, em função do atendimento deficiente acima citado e por ações punitivas, que embora previstas em contrato, contradizem o "espírito de parceria".

\footnotetext{
${ }^{7}$ Comunicado oficial da empresa "RESULTADOS $3^{\circ}$ TRIMESTRE".
} 
“... na fase de produção em série, não há diferenças entre parceiros e fornecedores.”

A forma utilizada para a obtenção das informações até aqui expostas privilegiou uma abordagem geral e de conteúdo quanto ao relacionamento de parceria entre a Embraer e um grupo de fornecedores do projeto EMB-170/190, não possibilitando e não pretendendo captar e explicitar as diferenças e especificidades existentes na relação com cada um dos parceiros.

\subsubsection{Características específicas da parceria}

Um questionário estruturado foi utilizado para coletar dados com os informantes-chaves, objetivando verificar a presença das características componentes do modelo, apresentado na Figura 4 do Capítulo 2, no relacionamento de parceria que foi objeto de estudo desta pesquisa.

Os informantes-chaves foram os Gerentes de Parceria, conforme representado na Figura 9 do capítulo anterior, os quais são responsáveis pela gestão dos fornecedores sobre todos os aspectos do relacionamento com a Embraer, atuando através de uma equipe de profissionais de suprimentos que administram cada um desses aspectos.

O questionário foi respondido, pelos Gerentes respectivos, para cada um dos onze parceiros participantes do projeto EMBRAER 170/190, conforme apresentado no item 4.2.3, sob a ótica da empresa quanto ao relacionamento com o parceiro.

Os Gerentes respondentes apresentam uma experiência média de nove anos em suprimentos, dos quais seis anos na Embraer e dois anos e meio na posição de gestores dos parceiros do projeto EMB-170/190. O Apêndice 3 apresenta um sumário dos dados demográficos coletados. Aqueles que apresentam menor tempo na função de gestor, já atuavam anteriormente como componentes da equipe respectiva tendo, portanto, conhecimento específico e completo sobre o parceiro, o que assegura a representatividade das informações coletadas.

Uma análise descritiva dos dados coletados, para cada uma das características componentes do modelo conceitual e que foram mensuradas através do questionário aplicado, é apresentada nos tópicos a seguir. Essa análise foi feita com base na opinião predominante dos respondentes através de média e freqüência percentual. 
Como os construtos foram medidos por uma escala multi-item, para efetuar esta análise, os mesmos foram rearranjados. Cada uma das características estudadas foi agrupada de forma a que ficasse representada por um item único.

O rearranjo das características foi feito da seguinte forma:

1) Agrupar os graus da escala Likert das respostas obtidas em um único fator tanto para concordância, como para discordância $\rightarrow$ concordância $=5$; discordância $=1$;

2) Considerar a resposta neutra (não concordo nem discordo) como "missing”;

3) Unificar cada característica pela predominância de concordância ou discordância nas cinco medidas agrupadas, para cada um dos respondentes.

Como a medição foi efetuada utilizando-se escala direta, concordância significa evidência da presença do atributo no relacionamento entre os parceiros.

Excertos dos comentários efetuados pelos respondentes, conforme previsto na parte final do questionário, são apresentados para ilustrar e complementar os resultados apresentados.

No Apêndice 4 são mostradas as tabelas de freqüência para cada uma das características analisadas a seguir. A numeração constante em cada uma das características, nas tabelas respectivas, faz equivalência com os enunciados dos itens utilizados para mensuração dos construtos, conforme apresentado no tópico 3.4.2 do Capítulo 3.

\subsubsection{Confiança}

As afirmativas do questionário visavam captar o nível de confiança existente entre os parceiros.

A unificação das cinco assertivas utilizadas para mensurar este atributo resultou em um indicador de concordância de $80 \%$ dos respondentes, apontando para a presença de confiança no relacionamento.

Os aspectos que obtiveram um índice de concordância significativo (superior a 75\%) foram: integridade e atuação eficaz do fornecedor para atendimento aos objetivos. 
“... possui alta competência técnica e experiência no sistema que nos fornece, sendo um parceiro forte e competente....."

Em um patamar inferior, com 56\% de concordância entre os respondentes, ficou ter transparência quanto à responsabilidade sobre os problemas que surgem e não fazer reivindicações infundadas.

"As reivindicações do fornecedor têm sempre motivação financeira e são causadas por motivações reais.”

Por outro lado, houve uma visão majoritária (86\%) de que o parceiro não cumpre com suas promessas, o que age de forma negativa sobre a confiança entre as partes.

"O fornecedor tem péssima gestão de seus recursos, tanto internos como externos, o que gera constantes falhas e desatendimentos aos compromissos firmados.”

\subsubsection{Comprometimento}

As questões colocadas quanto a este quesito pretendiam identificar o comprometimento do parceiro para com a Embraer.

O resultado obtido mostra que $70 \%$ dos respondentes concordam que existe comprometimento com o relacionamento por parte dos parceiros.

Analisando as assertivas de forma individual, duas obtiveram concordância da maioria dos respondentes, a qual foi significativa (acima de 75\%), caracterizando que os parceiros se dispõem a fazer investimentos de longo prazo para dar suporte ao projeto no qual estão engajados e que consideram este relacionamento como uma parceria de longo prazo.

Em contrapartida, há a percepção de que o senso de lealdade por parte do parceiro com a empresa não é suficientemente forte, podendo levar a que o mesmo dê preferência a outro cliente em detrimento da Embraer em determinadas situações.

"Relacionamento comercial com outro cliente é prioritário." 
“... se houver um contrato significativo com outro cliente, o nível de prioridade em relação à nossa empresa pode diminuir.”

Adicionalmente, obteve-se também a percepção de que a dedicação dos recursos necessários para o projeto, pelos parceiros, não é satisfatória e, de forma geral, o comprometimento não é suficiente.

"Necessidade de longas discussões para iniciar modificações ou atividades que necessitem de investimentos de mão-de-obra ou material."

"Insuficiente comprometimento com o programa 170/190 em todos os níveis."

Estes aspectos podem ser considerados como ações com visão de curto prazo, contrapondo ao comprometimento de longo prazo constatado nos itens anteriores.

\subsubsection{Cooperação}

As assertivas buscavam tratar do nível de cooperação existente entre a Embraer e os parceiros.

Houve unanimidade para todas as afirmativas, com concordância de $90 \%$ dos respondentes.

A presença do espírito de colaboração entre as empresas está associada à disposição de ambas as partes prestarem ajuda, de diversas formas, quando solicitada.

"São extremamente abertos, receptivos e informais."

Adicionalmente, há a busca por tratar os problemas que surgem de forma conjunta, cooperar de diversas formas e planejar atividades ou projetos conjuntos com o fornecedor. 


\subsubsection{Interdependência}

O questionário quanto a este atributo pretendia avaliar a existência de dependência entre as empresas.

O resultado apurado indica a presença de dependência entre as partes, pois a grande maioria dos respondentes (91\%) concordou com as afirmações apresentadas neste sentido no instrumento de pesquisa.

"A exclusividade sempre será um problema para qualquer relacionamento comercial, uma vez que caracteriza total dependência e, portanto, alto risco ao negócio.”

Isto significa que é considerado difícil e de alto custo que um dos parceiros substitua o outro, o que faz todo sentido pelas características do processo necessário para desenvolver um componente substituto e pelo investimento já realizado no projeto por ambas as partes.

"Neste negócio o cliente é sempre dependente do fornecedor, uma vez que a substituição é muito onerosa."

Uma outra análise indica que há dependência assimétrica no relacionamento, sendo considerado pelos respondentes que esta dependência é maior por parte da Embraer: enquanto $82 \%$ concordam que a Embraer é dependente do parceiro, apenas 37\% têm essa visão do parceiro em relação à Embraer.

“O fornecedor possui o domínio do mercado neste segmento."

"Nossa empresa representa perto de $75 \%$ do faturamento do fornecedor."

\subsubsection{Compartilhamento de informação}

As afirmações do questionário tratam da extensão em que há troca de informações relevantes entre as empresas.

A análise das respostas leva a concluir que este atributo está bem presente no relacionamento, já que houve concordância da maioria dos respondentes com todas as assertivas apresentadas no questionário. 
Verifica-se que, para $80 \%$ dos respondentes, ocorre compartilhamento de informação relevante em ambas as direções e há consciência de que eventos e situações que possam afetar ou ajudar a outra parte sejam comunicados quando de seu conhecimento por uma das empresas. No entanto, um ponto de atenção enfatizado está no fato de que o mesmo fornecedor atua em competidores diretos.

"O fornecedor estando presente no concorrente é um fator relevante quando entramos no campo de troca de informações e visões."

A antecedência com que mudanças necessárias são informadas pela Embraer aos parceiros obteve concordância de $57 \%$ dos respondentes, próximo da neutralidade, indicando que, apesar de positiva, não está em um nível adequado para uma parceria.

“... pecamos no ponto de comunicação adequada, gerando conflitos muitas vezes despropositados por falta de informação das partes ou mesmo choques culturais."

\subsubsection{Participação e qualidade na informação}

As questões colocadas para apurar este aspecto do relacionamento de parceria tratam da extensão do envolvimento das partes no planejamento e definição de metas comuns e da qualidade da informação partilhada.

O resultado obtido aponta que não há presença destas características no relacionamento, segundo a percepção de $62,5 \%$ dos respondentes.

Por um lado, em torno de $60 \%$ dos respondentes concordam que há disposição da Embraer em obter aconselhamento e sugestões de melhoria dos parceiros e, portanto, fazer com que haja participação deles em subsidiar as decisões da empresa, embora percebam a presença de dificuldades de alinhamento em função de diferenças culturais.

"As culturas das duas empresas são muito diferenciadas."

"Extrema dificuldade de comunicação com este fornecedor face às barreiras culturais." 
Por outro lado, mais de 70\% dos respondentes avaliam que não há participação de uma parte nas atividades de planejamento e estabelecimento de metas da outra parte que sejam relevantes para o relacionamento. Adicionalmente, $67 \%$ consideram de baixa qualidade a comunicação existente entre as empresas.

"A falta de planejamento de mais longo prazo e comunicação eficaz me parece ser uma das grandes causas dos problemas enfrentados, de lado a lado."

\subsubsection{Técnicas de resolução de conflitos}

As assertivas relativas a este construto visavam identificar as formas mais freqüentemente utilizadas para resolver os conflitos que surgem naturalmente nos relacionamentos entre empresas.

De acordo com as respostas obtidas, há a predominância na frequiência de uso dos estilos de dominação - satisfazer o próprio interesse em detrimento da outra parte, e de compromisso chegar a um acordo de meio termo, com uma leve tendência para este último.

"Houve uma deterioração crítica do relacionamento como resultado de algumas ações negativas tomadas por ambas as partes.”

“Baixa propensão para mudar condições comerciais já acordadas, objetivando conquista de novos mercados."

No outro extremo, são muito pouco utilizadas as técnicas de subestimação - negar-se à reconhecer o conflito, e de acomodação - ceder para satisfazer a outra parte.

Finalmente, a abordagem colaborativa - buscar solução ganha-ganha, ocorre ocasionalmente nas resoluções de conflito entre as empresas, conforme avaliação dos respondentes.

“... tem-se de lidar com o legado de enormes problemas causados no passado, o que eventualmente cria um preconceito de que ofornecedor é sempre causador dos problemas." 


\subsubsection{Satisfação geral}

O questionário quanto a este construto buscava apurar a satisfação dos respondentes com o relacionamento de parceria com os respectivos fornecedores.

Neste aspecto, o resultado obtido indica insatisfação com o relacionamento de parceria, por parte de $64 \%$ dos respondentes.

"A constante mudança de prioridade e a falta de clareza na colocação de nossas necessidades e objetivos ajuda a contribuir para a insatisfação causada por eventuais falhas percebidas como sendo do fornecedor."

As respostas indicam uma insatisfação unânime (100\%) com o suporte e serviços prestados pelos parceiros para a Embraer. Além disso, uma maioria significativa dos respondentes (mais de 70\%) mostrou-se insatisfeita quanto a negociar com o parceiro, bem como apontou no sentido de que o parceiro não é modelo de referência a ser seguido por outros fornecedores.

"Baixo engajamento do parceiro em questões comerciais e nos riscos de comercialização do produto final."

“... eles estão menos flexíveis nas negociações e reativos.”

Da análise das respostas surge ainda que a maioria (71\%) gostaria de dar continuidade ao relacionamento com o parceiro no futuro, apesar de que $56 \%$ dos respondentes não estão atualmente satisfeitos com o estágio atual do relacionamento.

"Parceiro possui atuação global, atingindo uma das metas desta parceria que é o suporte aos clientes distribuídos pelo mundo.”

\subsubsection{Correspondência entre os construtos}

Uma análise por meio de tabelas de contingência foi realizada para verificar a presença de correspondência ou associação entre os construtos conforme sugerido pelo modelo conceitual, 
utilizando os dados coletados através do questionário estruturado aplicado aos informantes chaves conforme detalhado anteriormente.

No Apêndice 5 são mostradas as tabelas de contingência que relacionam as características analisadas a seguir.

\subsubsection{Atributos da parceria e Satisfação geral}

As tabelas de correspondência analisadas expõem os seguintes resultados:

- Confiança x Satisfação $=60 \%$ das respostas mostram associação direta entre estas características, ou seja, aqueles que entendem que a confiança está presente no relacionamento com o fornecedor mostram-se satisfeitos com a parceria e quando não há confiança, surge insatisfação. Por outro lado, para 40\%, mesmo havendo evidência de confiança, não estão satisfeitos com o parceiro;

- Comprometimento x Satisfação = correspondência direta entre estas características também é mostrada pelas respostas de 70\% dos informantes. Quando consideram que há comprometimento do parceiro, dizem-se satisfeitos com o relacionamento, o mesmo acontecendo em sentido inverso (falta de comprometimento x insatisfação). Os $30 \%$ restantes, evidenciam a falta de comprometimento e não estão satisfeitos com o parceiro;

- Interdependência $\mathrm{x}$ Satisfação = a associação entre estas características mostra-se inversa por uma pequena margem, ou seja, aqueles que consideram que há interdependência na parceria (54,5\%), não estão satisfeitos com o relacionamento. Enquanto isso, interdependência tem associação direta com satisfação para os demais $45,5 \%$, sendo positiva para $36,4 \%$ dos respondentes;

- Cooperação x Satisfação $=60 \%$ das respostas mostram associação inversa entre estas características, ou seja, aqueles que entendem que a cooperação está presente no relacionamento com o fornecedor mostram-se insatisfeitos com a parceria. Por outro lado, para $40 \%$, há correspondência direta - havendo evidência de cooperação, estão satisfeitos com o parceiro; não havendo cooperação, surge insatisfação.

Em resumo, de acordo com as tabelas de contingência analisadas, confiança e comprometimento mostram associação direta com a satisfação com a parceria. Enquanto o mesmo não ocorre com interdependência e cooperação. 


\subsubsection{Comportamento na comunicação e Satisfação geral}

Pelas tabelas de contingência, os seguintes resultados foram obtidos:

- Compartilhamento de informação x Satisfação $=60 \%$ das respostas mostram associação inversa entre estas características, ou seja, a presença de compartilhamento de informação entre os parceiros não está gerando satisfação com o relacionamento para estes informantes;

- Participação e qualidade da informação x Satisfação = mais de $85 \%$ das respostas refletem uma correspondência direta entre estes atributos, sendo que a maioria que mostra insatisfação com a parceria $(62,5 \%)$ opina que a participação e a qualidade da informação partilhada não ocorrem, enquanto $25 \%$ têm opinião inversa.

Resumindo, apesar de considerar que o compartilhamento de informação está presente na parceria com o fornecedor, a maioria dos respondentes não está satisfeita com o relacionamento. Por outro lado, aqueles que estão insatisfeitos com a parceria consideram que a participação e a qualidade das informações trocadas não são adequadas.

\subsubsection{Resolução de conflitos e Satisfação geral}

As tabelas de contingência analisadas quanto à relação entre estes construtos propiciaram os seguintes resultados:

- Dominação x Satisfação $=71 \%$ das respostas vão à direção de uma associação inversa entre estas características, sendo que, para $57 \%$ o uso da técnica de dominação para resolver conflitos contribui para a insatisfação com o relacionamento;

- Colaboração x Satisfação = não computada, pois foi associado menos de $50 \%$ do total de respostas, não sendo considerado representativo;

- Subestimação x Satisfação = correspondência direta entre estas características é mostrada pelas respostas de $75 \%$ dos informantes. Para $62,5 \%$ não há o uso do estilo de subestimação e dizem-se insatisfeitos com a parceria;

- Acomodação x Satisfação = não computada, pois foi associado menos de $50 \%$ do total de respostas, não sendo considerado representativo;

- Compromisso x Satisfação = resultado neutro, ou seja, 50\% das respostas revelaram associação direta entre as características e outros $50 \%$ mostraram inversa. 
Como resumo, o uso da técnica de dominação para a resolução de conflitos entre os parceiros pode ser associado com a insatisfação com o relacionamento indicada pelos respondentes. Por outro lado, a técnica de subestimação não contribui para a insatisfação com a parceria.

\subsubsection{Relação entre "Atributos da parceria"}

As tabelas de contingência analisadas quanto à associação entre as características componentes deste construto gerou os seguintes resultados:

- Confiança $\mathrm{x}$ Comprometimento $=89 \%$ das respostas refletem uma correspondência direta entre estes atributos, sendo que $67 \%$ concordaram com a presença de confiança e comprometimento na parceria e os restantes tiveram a posição inversa;

- Confiança x Cooperação = correspondência direta positiva também existente para 78\% dos respondentes;

- Comprometimento x Cooperação = havendo comprometimento, 56\% identificam também a presença de cooperação;

- $\quad$ Confiança $x$ Interdependência $=70 \%$ indicam associação direta positiva de confiança com interdependência

- Comprometimento $\mathrm{x}$ Interdependência = daqueles que evidenciam comprometimento na parceria, $60 \%$ também atestam interdependência.

\subsection{Análise dos resultados}

Conforme detalhado no Capítulo 3, nesta etapa é feito o cruzamento das informações e dos resultados obtidos, conforme apresentado no tópico anterior, com a fundamentação teórica preparada para esta pesquisa.

\subsubsection{Aspectos gerais}

O primeiro ponto relevante diz respeito à definição de parceria. 
A visão apresentada pelos entrevistados faz uma conceituação restrita do relacionamento de parceria existente com os fornecedores do projeto EMB-170/190. Entende a parceria como uma relação estabelecida para o desenvolvimento do produto e para compartilhamento dos riscos associados. Enfatiza o aspecto técnico e financeiro do relacionamento e não está totalmente alinhada com o conceito mais amplo apresentado na literatura pesquisada, a qual destaca também a importância de vínculos sociais (características comportamentais) e considera parceria como uma abordagem holística da gestão de cadeias de suprimentos (MENTZER et al, 2000; HUMPHRIES; WILDING, 2001).

Um ponto convergente entre a visão coletada nas entrevistas e a literatura diz respeito à definição clara de objetivos comuns. Estes objetivos estão em fase com aquilo que é previsto na literatura - compartilhar incertezas e custos, ter acesso a tecnologias novas e complementares, reduzir tempo para inovações, expandir a gama de produtos (GULATI, 1995), podendo ser resumido na busca por vantagem competitiva.

Os objetivos complementares citados de expandir relações com outros continentes e buscar fornecedores em outros nichos de mercado foram atingidos no processo de seleção dos parceiros, mas, em contrapartida, mostraram-se contraproducentes em determinados casos, pois questões de choque cultural acabaram interferindo de forma negativa em outros aspectos do relacionamento, por exemplo, criando dificuldade de comunicação e de alinhamento estratégico entre as empresas.

Um aspecto interessante para reflexão diz respeito aos contratos formais estabelecidos com os parceiros logo após a seleção final das empresas fornecedoras.

As características e complexidade do produto, o longo ciclo de vida, a necessidade de garantir suporte técnico e material aos clientes e os riscos e custos associados à responsabilidade legal em casos de incidentes e acidentes, evidenciam a necessidade de respaldo jurídico para o relacionamento estabelecido.

No entanto, alguns autores - Roxenhall e Ghauri (2004); Bronzo (2004); Lusch e Brown (1996), postulam que, em relacionamentos de parceria, os contratos formais deveriam ser menos rígidos e detalhados e mais flexíveis, até porque é difícil prever todas as contingências, o que reduziria os custos de transação. 
A pesquisa de Roxenhall e Ghauri (2004) mostra que os contratos são pouco usados para resolver disputas que surgem, pois as empresas buscam manter boas relações entre si e procuram resolver suas pendências informalmente, flexibilizando as cláusulas contratuais na prática, fato este observado também neste estudo de caso.

As diferenças citadas pelos entrevistados entre "parceiro" e "fornecedor" vão à mesma linha restrita adotada para a definição do relacionamento de parceria, ficando também focadas em aspectos associados ao desenvolvimento do produto: aporte financeiro, amplitude da responsabilidade e do risco assumido e grau de integração no projeto. Não há nenhuma referência aos aspectos comportamentais do relacionamento sugeridos pela literatura e representados neste trabalho pelo modelo conceitual apresentado, considerando que esses aspectos distinguem parcerias dos relacionamentos tradicionais (MOHR; SPEKMAN, 1994).

Os resultados obtidos com as informações sobre desempenho quantitativo mensurável qualidade, preço e atendimento a prazos, estão alinhados com a discussão teórica apresentada quanto a não serem pontos relevantes de diferenciação entre formas distintas de relacionamento, o que significa que não são considerados indicadores capazes de evidenciar singularidades em uma parceria em comparação com relacionamentos tradicionais, ou seja, são indiferentes quanto ao tipo de relacionamento existente entre as partes (LEMKE et al, 2003).

Se por um lado considera-se a parceria como bem sucedida em função de ter atendido aos objetivos de desenvolvimento do produto e pelo sucesso comercial alcançado pelo produto no mercado, por outro lado há a evidência da insatisfação dos gestores com o relacionamento entre as empresas, na fase atual de produção em série, em função da deficiência no atendimento à demanda de produção/mercado por diversos fatores.

Essa insatisfação ficou patente com o resultado da avaliação feita através do questionário que mediu o atributo "satisfação geral”, indicando que o suporte e serviços prestados pelo parceiro não estão adequados, as negociações são desgastantes e o parceiro não seria utilizado como exemplo para outros. 
O impacto que vem sendo causado por alguns parceiros à produção, resultando em não atendimento aos prazos e à demanda, têm um peso significativo na insatisfação causada com a parceria. Embora o volume de vendas tenha se mostrado bem superior ao previsto originalmente pelo plano de negócio do projeto, a deficiência ao atendimento pode ser creditada à falta de capacidade de reação e de flexibilidade dos parceiros, possivelmente gerada por razões como: perda de capacidade financeira em função de planejamento de custos inadequado na fase de desenvolvimento; falta de confiança e de comunicação adequada quanto às previsões de mercado.

O excessivo direcionamento da parceria para a fase de desenvolvimento do produto é diagnosticado hoje pelos próprios executivos que participaram na implantação do modelo para o projeto. Apesar da dificuldade natural de obter, com antecedência, na fase de desenvolvimento, informações e cenários que propiciassem um planejamento detalhado das fases seguintes - produção e pós-venda, era necessário ampliar a visão e estruturar uma estratégia empresarial para o desdobramento da parceria. A avaliação de riscos e competências dos parceiros deve incluir todas as fases, prevendo desempenho futuro.

Neste sentido, parece interessante considerar que o modelo conceitual apresentado neste trabalho propõe elementos a serem trabalhados e desenvolvidos em um processo de parceria, para possibilitar que haja sucesso do relacionamento no longo prazo, ou seja, durante todas as fases da vida do produto.

A experiência prévia é um fator importante para o sucesso de parcerias, pois o aprendizado capacita as empresas a desenvolver habilidades para lidar com este tipo de relacionamento (KALE et al, 2002).

A experiência anterior com a parceria no projeto ERJ-145 trouxe certo grau de capacitação e entendimento deste tipo de relacionamento. No entanto, a complexidade muito maior do projeto EMB-170/190, tanto no aspecto técnico quanto no escopo ampliado das responsabilidades transferidas para os parceiros e no número de empresas envolvidas, requeria um outro patamar de habilidade de gestão de relacionamentos na cadeia de suprimentos. 
A ampliação do escopo de fornecimento por parte dos parceiros foi suprida, na prática, através da atuação como empresa focal que eles passaram a desempenhar. Isto significou que a Embraer enxergava cada parceiro como fonte única para as negociações, discussões técnicas e operacionalização do processo de compras do sistema completo (pacote tecnológico) que estava sob a responsabilidade de cada parceiro. Por seu lado, o parceiro estava capacitado para fabricar e fornecer parte do pacote tecnológico e teve, portanto, que complementá-lo através da contratação de outros fornecedores especializados, os quais não faziam parte de sua cadeia de suprimentos habitual.

A habilidade de planejar e gerenciar a cadeia de suprimentos é uma competência essencial para as empresas (FINE, 1999). Parte dessa competência demonstrada pela Embraer no projeto ERJ-145 foi, de certa forma, delegada aos parceiros no projeto EMB-170/190, quando a empresa optou por passar a adquirir sistemas completos.

A Embraer parece ter superestimado a capacidade de cada parceiro em gerir a cadeia de suprimentos ampliada, que resultou do aumento do escopo de fornecimento pelo qual ficaram responsáveis, e não se preparou adequadamente para desempenhar o novo papel de administrar a complexidade da rede de interações e relacionamentos que resultou do modelo adotado, deixando toda a responsabilidade para os parceiros.

\subsubsection{Aspectos específicos}

O primeiro conjunto de características consideradas importantes para o estabelecimento de parcerias bem sucedidas em cadeias de suprimentos é formado pelo construto "Atributos da parceria" - confiança, comprometimento, cooperação, interdependência.

Os dados coletados, por meio do questionário estruturado aplicado aos informantes-chaves, apontaram para a presença de confiança no relacionamento de parceria fabricante-fornecedor estudado nesta pesquisa.

Este resultado corresponde ao que prevê a literatura, a qual considera a confiança entre as partes como uma variável fundamental e o principal indicador de relacionamentos colaborativos entre comprador e fornecedor (MORGAN; HUNT, 1994; WILSON, 1995). 
Considerando as duas dimensões que, segundo Ganesan (1994), formam a confiança: no que diz respeito a credibilidade - crença no conhecimento e eficácia do fornecedor, não foi plenamente atendida já que mesmo havendo concordância majoritária dos respondentes quanto à atuação eficaz e integridade do fornecedor, os aspectos de consistência e estabilidade ficaram prejudicados, pois houve a percepção de que as promessas não são cumpridas em muitas situações. Já o aspecto benevolência - intenções e motivos, foi atendido, em função da constatação de que há a crença de que o fornecedor age no sentido do melhor interesse do relacionamento, não fazendo reivindicações infundadas e tendo transparência no trato dos problemas que surgem.

De acordo com Johnson et al (2003), confiança está relacionada com altos níveis de satisfação. Esta relação positiva foi detectada na análise de correspondência realizada, tendo $60 \%$ das respostas mostrado associação direta entre confiança e satisfação geral com o relacionamento.

Outro atributo analisado - comprometimento - também foi percebido como presente na parceria, estando este resultado em fase com a literatura pesquisada. Autores como Krause (1999) e Morgan e Hunt (1994) consideram o comprometimento como um fator crucial em relacionamentos colaborativos.

A pesquisa mostrou que, mais especificamente, os parceiros estão dispostos a fazer investimentos para dar suporte ao projeto e vêem o relacionamento como sendo de longo prazo, o que também é explicitado nos trabalhos de Wilson (1995) e Monczka et al (1998b). Evidência neste sentido é obtida pela constatação de que alguns parceiros instalaram subsidiárias no Brasil, próximas à Embraer, para executar parte do processo produtivo localmente e prestar melhor apoio técnico e logístico.

Por outro lado, houve a percepção dos respondentes de que o comprometimento existente ainda não é suficiente e a dedicação de recursos precisa ser melhorada. Isto demonstra uma fragilidade deste atributo que precisa ser trabalhada, o que é natural, considerando que comprometimento leva tempo para ser construído (ANDERSON; WEITZ, 1992; KUMAR et al, 1995). 
O trabalho de Wren e Simpson (1996) aponta para uma relação muito próxima entre comprometimento e satisfação, enquanto Hibbard et al (2001) demonstraram que comprometimento age positivamente sobre o desempenho do relacionamento.

Neste mesmo sentido, a análise realizada nesta pesquisa mostra que há uma associação direta entre comprometimento e satisfação geral, tendo sido obtida uma concordância de $70 \%$ dos respondentes.

Um outro resultado obtido diz respeito à relação entre confiança e comprometimento. Foi detectado, por $89 \%$ das respostas, que há uma associação direta entre estas características. Daqueles que apontaram a presença de confiança no relacionamento de parceria, $85 \%$ também indicaram haver comprometimento.

Esta correspondência está presente na literatura pesquisada, que considera a confiança como um determinante e indutor do comprometimento com o relacionamento (MORGAN; HUNT, 1994; WILSON, 1995).

O atributo seguinte - cooperação - teve uma alta concordância (90\%) entre os respondentes quanto a ser uma característica presente na parceria estudada neste trabalho.

Morgan e Hunt (1994) tratam do aspecto essencial da cooperação nos relacionamentos entre empresas e Mohr e Spekman (1994) a consideram uma marca das parcerias de sucesso.

A disposição para promover ajuda mútua e trabalhos conjuntos, detectada nesta pesquisa, pode gerar benefícios para as empresas e satisfação com o relacionamento (ANDERSON; NARUS, 1990; HIBBARD et al, 2001).

A pesquisa não captou uma associação significativa entre cooperação e satisfação geral, contrariamente ao previsto na literatura e obtido em trabalhos anteriores (ANDERSON; NARUS, 1990; MORGAN; SPEKMAN, 1994).

Por outro lado, as análises de associação entre características do mesmo construto encontraram correspondência positiva entre confiança e cooperação, e também, entre comprometimento e cooperação, o que é encontrado na literatura sobre relacionamentos em 
cadeias de suprimentos, a qual postula que cooperação tem forte ligação com confiança e comprometimento, sendo influenciada diretamente por ambas (ANDERSON; NARUS, 1990; MORGAN; HUNT, 1994).

O atributo - interdependência - conclui o primeiro conjunto de características relevantes para os relacionamentos de parceria.

A interdependência obteve concordância de $91 \%$ dos respondentes no sentido de estar presente na parceria analisada.

Este resultado é coerente, considerando o alto custo e tempo necessário para o processo de certificação da aeronave - qualificação e homologação de acordo com as regulamentações das agências reguladoras dos diversos paises, e que este processo está associado a uma configuração específica do produto, ou seja, está vinculado ao pacote tecnológico fornecido. Além disso, há o aporte financeiro a risco empenhado por todos os parceiros e pela Embraer para o desenvolvimento do produto.

Conforme previsto na literatura, a dependência detectada está associada com a disponibilidade de fontes alternativas, com a magnitude dos investimentos e dos ativos envolvidos, e com a necessidade de manter o relacionamento para atingir as metas desejadas (GANESAN, 1994; GAO et al, 2005; HIBBARD et al, 2001).

Pesquisas mostram que interdependência tem impacto positivo no desempenho do relacionamento e gera satisfação (KUMAR et al, 1995; LUSCH; BROWN, 1996), mas esta associação não foi observada pelas análises realizadas neste trabalho.

No entanto, pode-se perceber correspondência positiva entre confiança e comprometimento com interdependência nesta pesquisa, conforme constatado no trabalho de Kumar et al (1995). A maioria dos respondentes que indicou haver confiança e comprometimento entre os parceiros fez associação também com a presença de interdependência.

Embora não tenha sido objetivo desta pesquisa e, consequentemente, não foi explorado na fundamentação teórica, os dados coletados indicaram uma percepção de dependência 
assimétrica entre as partes, sendo considerada maior da Embraer para com os parceiros, apesar de ocorrer situação inversa em casos específicos.

Esta visão pode ter ocorrido em função de que boa parte dos parceiros tem volume de negócios significativos com outras empresas, sendo a dependência quanto à Embraer um percentual menor do faturamento global. Esta percepção está em fase com o que foi detectado nas análises sobre comprometimento, em que houve indicações de que o parceiro pode dar preferência a outro cliente em determinadas situações.

Em resumo, quanto aos atributos da parceria, obteve-se a percepção dos respondentes de que na parceria da Embraer com os fornecedores do projeto EMB-170/190 há evidências de confiança, comprometimento, cooperação e interdependência, conforme sugerido pela literatura pesquisada para a elaboração deste trabalho.

O próximo conjunto de características consideradas importantes para parcerias entre empresas diz respeito ao "Comportamento na comunicação" - compartilhamento de informação, participação e qualidade na informação.

Analisando o aspecto de compartilhamento de informação, este obteve concordância unânime entre os respondentes como sendo uma característica presente na parceria.

Este resultado vai de encontro às afirmações dos autores pesquisados que atribuem um papel fundamental do compartilhamento de informação na eficácia dos relacionamentos (JOHNSON; SOHI, 2001; BOWERSOX et al, 2003).

De acordo com Anderson e Weitz (1992), o alto grau de troca de informações contribui para uma maior satisfação com o relacionamento. Esta associação não foi obtida nesta pesquisa, após a realização da análise de correspondência entre compartilhamento de informação e satisfação geral.

A participação e qualidade na informação foi outro atributo analisado e que compõe o construto da comunicação. 
Segundo as respostas coletadas, essa característica não foi considerada presente na parceria avaliada, contrariamente ao que diz a literatura.

A análise do resultado obtido mostra que não há planejamento conjunto, embora a empresa busque opiniões e sugestões junto aos parceiros, e que a qualidade da informação trocada não é satisfatória, considerando os aspectos de acurácia, adequação, credibilidade, temporalidade e abrangência.

De acordo com a literatura pesquisada, a qualidade insatisfatória da informação trocada com os parceiros tem impacto negativo na confiança entre as partes e gera incerteza ao relacionamento, podendo afetar o desempenho global da cadeia de suprimentos (MORGAN; HUNT, 1994; JOHNSON; SOHI, 2001).

Adicionalmente, autores como Lambert et al (1999) e Mohr e Spekman (1994), sugerem que o planejamento conjunto - participação na tomada de decisões e na formulação de metas, está associado à satisfação e ao sucesso da parceria.

A análise realizada neste trabalho, quanto à relação deste atributo com satisfação geral, verificou que $62,5 \%$ dos respondentes que consideram que a participação e qualidade na informação não estão presentes no relacionamento, não estão satisfeitos com a parceria, resultado alinhado com a literatura reportada.

Em resumo, no que diz respeito à comunicação, esta pesquisa obteve a percepção dos respondentes de que há compartilhamento de informação entre a Embraer e os parceiros, mas a qualidade da informação não é satisfatória e não há o envolvimento necessário dos parceiros, podendo levar a falta de comprometimento e ter um impacto negativo sobre o relacionamento.

A Embraer tem desenvolvido iniciativas com ênfase na melhoria da comunicação em todos os aspectos acima relatados. Dentre as mais significativas, vale destacar: o conselho de fornecedores - Embraer \& Suppliers Advisory Council - que explora formas de melhorar comunicação, partilhar melhores práticas e iniciativas estratégicas; a conferência anual com os fornecedores - Esmbraer Suppliers Conference - para discutir tendências e perspectivas da indústria e do mercado, desempenho e metas. 
As técnicas de resolução de conflitos utilizadas na parceria compõem o próximo construto analisado.

Considerando que o conflito é inerente e inevitável em relacionamentos entre empresas, a forma como é feita sua gestão impacta o sucesso e continuidade da parceria (DUARTE; DAVIS, 2003).

O resultado oriundo das informações coletadas estabeleceu que dominação e compromisso são os estilos predominantes utilizados no trato dos conflitos que surgem nesta parceria.

A dominação significa que uma das partes busca impor seus interesses sobre a outra parte, na solução do conflito. Esta abordagem é considerada uma solução de curto prazo que tende a exacerbar as diferenças e pode afetar negativamente o relacionamento no longo prazo (GRAHAM, 1998; MOHR; SPEKMAN, 1994).

Esta situação foi encontrada nesta pesquisa, na qual foi observada a deterioração do relacionamento com alguns parceiros em função de ações impositivas tomadas por ambas as partes, levando à insatisfação com o relacionamento.

A relação inversa do estilo de dominação com a satisfação geral também foi observada pela análise de correspondência entre os construtos, o que vai de encontro ao propugnado na literatura por diversos autores - Lin e Germain (1998); Mohr e Spekman (1994); MedinaMuñoz e García-Falcon (2000).

A resolução de conflito através de um acordo de meio termo com concessão de ambas as partes - compromisso, surge na literatura como sendo uma solução paliativa que pode não ser efetiva e fará com que o problema retorne no futuro (GRAHAM, 1998).

Nesta pesquisa, a solução dos problemas por compromisso entre as partes apresentou uma freqüência de utilização alta na opinião de $83 \%$ dos respondentes que tomaram uma posição clara na assertiva apresentada, mas não evidenciou associação com a satisfação geral com o relacionamento, enquanto a literatura considera que este estilo causa um impacto negativo na parceria. 
A utilização freqüente da abordagem de compromisso pode fazer com que as partes envolvidas inflem suas demandas iniciais, já sabendo que terão que ceder para chegar a um acordo, o que faz com que não seja eficaz na resolução do conflito (GRAHAM, 1998).

As técnicas de subestimação - ignorar o conflito, e acomodação - ceder à outra parte, foram consideradas como não utilizadas na parceria em questão, o que está em fase com a literatura que não aconselha sua aplicação, considerando que ambas têm impacto negativo sobre o relacionamento, pois não endereçam o problema (WEITZ; BRADFORD, 1999).

A técnica de colaboração - buscar solução ganha-ganha, considerada pela literatura como sendo a mais adequada e eficaz para solucionar os conflitos em parcerias (RAHIM, 2002), teve uma evidência de utilização ocasional nesta parceria, não sendo significativa sua presença.

Um ponto interessante a considerar é que a abordagem de compromisso é bem próxima da colaboração, já que ambas têm característica integrativa, evidenciam preocupação e trazem retorno para ambas as partes. A diferença está no nível de preocupação demonstrado, pois enquanto compromisso está focado em uma solução aceitável - dividir o bolo existente, colaboração busca uma solução mais ampla - expandir o bolo antes de repartir.

Sumarizando, quanto à resolução de conflitos, os resultados obtidos indicam a utilização das técnicas de dominação e compromisso como sendo as mais freqüentes nesta parceria.

A satisfação geral obteve um índice de $64 \%$ de discordância por parte dos respondentes, o que significa que há insatisfação com a parceria.

Analisando os pontos específicos abordados no questionário, destaca-se a insatisfação com o suporte e serviços prestados pelos parceiros, que foi unânime entre os respondentes. Isto está ligado fortemente à deficiência observada no atendimento à demanda para a produção, o que tem impactado negativamente o desempenho de entrega aos clientes. 
Outro aspecto contribuinte para a insatisfação detectada diz respeito às dificuldades enfrentadas quanto às negociações entre as partes, o que vem desgastando o relacionamento ao longo do tempo.

No entanto, a maioria dos respondentes indicou a intenção de dar continuidade ao relacionamento no futuro.

Esta aparente desconexão pode estar relacionada aos seguintes pontos:

- Uma visão de mais longo prazo que considera as dificuldades atuais como pontuais e superáveis;

- O sentimento de que outros aspectos considerados positivos, como confiança, comprometimento e cooperação, e que estão presentes na parceria, podem superar os aspectos negativos;

- A visão prática de que a interdependência entre as partes e os vínculos contratuais dificultariam, em termos legais e econômicos, a descontinuidade do relacionamento.

Autores como Gulati (1998) e Johnson et al (2003) atestam que a continuidade do relacionamento não significa que há avaliação positiva da parceria, pois pode haver restrição de fontes alternativas, altos custos associados, vínculos contratuais ou mesmo falta de desejo das partes em alterar a situação vigente.

Este capítulo detalhou os dados e informações coletadas durante o estudo de caso por meio de observação direta, análise documental, entrevistas e questionário estruturado, e procedeu à análise dos resultados observados tomando por base a fundamentação teórica apresentada anteriormente, preparando a argumentação para discutir as proposições desta pesquisa.

No capítulo seguinte é efetuado o encerramento do estudo de caso com a apresentação das conclusões do trabalho. 


\section{DISCUSSÕES E CONCLUSÕES}

O capítulo inicia apresentando uma visão geral deste estudo. Em seguida, faz uma discussão dos resultados, implicações, limitações deste trabalho e apresenta indicações para estudos futuros e as conclusões finais.

\subsection{Visão geral do trabalho}

O presente estudo partiu da premissa de que relacionamentos de parceria têm uma importância vital para o desempenho e busca de vantagem competitiva em cadeias de suprimentos, e que o sucesso destes relacionamentos está associado a algumas características e atributos relevantes.

O propósito deste trabalho foi estudar a presença destas características em um relacionamento de parceria fabricante-fornecedor, tendo como referência o modelo de Mohr e Spekman, oriundo da literatura pesquisado, e revisitado pelo autor.

O modelo conceitual utilizado relaciona três categorias de características comportamentais (qualitativas) como indutoras de parcerias bem sucedidas em cadeias de suprimentos: atributos da parceria - confiança, comprometimento, interdependência, cooperação; comportamento na comunicação - compartilhamento de informação, participação e qualidade da informação; técnicas de resolução de conflitos - dominação, colaboração, subestimação, acomodação, compromisso.

A pesquisa foi desenvolvida por meio de um estudo de caso em uma indústria aeronáutica, sob a perspectiva do fabricante quanto ao relacionamento de parceria com um grupo de fornecedores, buscando captar a percepção quanto à presença das características componentes do modelo conceitual neste relacionamento. 


\subsection{Discussões e implicações}

Os resultados do estudo indicaram que, pela perspectiva do fabricante, o relacionamento de parceria com os fornecedores apresenta como relevantes os atributos: confiança, comprometimento, cooperação e interdependência e que destes, confiança e comprometimento apresentaram associação positiva com satisfação geral com a parceria.

O estudo mostrou que a confiança no fornecedor está baseada em integridade e capacidade de atuar de forma eficaz para atender as expectativas do fabricante, o que está de acordo com a literatura (GANESAN, 1994; MORGAN; HUNT, 1994). Além disso, o resultado obtido indicou a presença de transparência quanto aos problemas que surgem e que o fornecedor não faz reivindicações infundadas, o que significa que não atua de forma oportunista, contribuindo para a satisfação do fabricante com o relacionamento (GAO et al, 2005; KUMAR, 1995).

No que diz respeito a comprometimento, conforme previsto nos trabalhos de Wilson (1995) e Monczka et al (1998b), o estudo obteve a percepção de que o fornecedor está disposto a fazer os investimentos necessários para dar suporte à parceria e a considera como um relacionamento de longo prazo. No entanto, o estudo evidenciou a necessidade do parceiro melhorar quanto à dedicação de recursos para satisfazer as necessidades da empresa.

Conforme apresentado pelos trabalhos de Wilson (1995) e Morgan e Hunt (1994), este estudo detectou uma associação direta entre confiança e comprometimento, o que contribui para o sucesso da parceria.

Outro resultado obtido indica que confiança e comprometimento influenciam a cooperação e a interdependência entre as partes, também convergindo para o que está na literatura pesquisada (MORGAN; HUNT, 1994; KUMAR et al, 1995).

Os resultados também apontam que a interdependência presente na parceria aqui estudada se dá em função da dificuldade e do alto custo associado à substituição do parceiro, o que é tratado na literatura como relacionado à escassez de fontes alternativas e ao investimento aplicado ao projeto (GANESAN, 1994; GAO et al, 2005). 
No aspecto de comunicação, este estudo identificou a presença do compartilhamento de informações entre os parceiros, o qual tem um papel fundamental na eficácia dos relacionamentos (BOWERSOX, 2003). Por outro lado, a qualidade da informação trocada não foi considerada satisfatória e foi evidenciado que não há participação das partes nas atividades de planejamento que influenciam a parceria, o que é contrário às recomendações da literatura pesquisada (MORGAN; HUNT, 1994; LAMBERT et al, 1999).

O estudo também obteve correspondência entre participação e qualidade na informação com a satisfação geral com a parceria.

Os resultados obtidos com relação às técnicas de resolução de conflitos indicam que dominação e compromisso são os estilos mais frequentemente utilizados nesta parceria. De acordo com a literatura, estas abordagens têm um impacto negativo na satisfação (GRAHAM, 1998), e este estudo obteve esta associação para dominação, mas o mesmo não ocorreu com compromisso.

$\mathrm{O}$ estudo apurou que a parceria foi bem sucedida quando se considera que foi atingido o objetivo de viabilizar o projeto nas diversas dimensões propostas - técnica, econômicofinanceira e temporal, e que o resultado de vendas atingido foi bem superior ao previsto no plano de negócio inicial, mas também evidenciou a insatisfação atual com o relacionamento na avaliação dos Gerentes da Parceria.

Isto demonstra que a concepção do modelo de parceria teve foco excessivamente na fase de desenvolvimento do produto, não tendo tido uma preocupação com uma abordagem mais ampla que preparasse o relacionamento adequadamente para as fases seguintes. Vencida a etapa de viabilização do projeto, as dificuldades de adequação e capacitação rápida dos parceiros para a etapa de produção ensejaram a deficiência observada quanto ao atendimento da demanda, conduzindo a um desgaste significativo do relacionamento, e conseqüentemente, gerou a insatisfação apurada por este estudo.

Embora a presença de confiança, comprometimento, cooperação e interdependência tenham sido verificados nesta parceria, a insatisfação detectada com o relacionamento sugere que estes atributos não estão em um nível suficiente para evitar os conflitos e as negociações desgastantes entre as partes. 
Pelos resultados obtidos, um ponto importante a ser trabalho diz respeito à melhoria do processo de comunicação, com um maior envolvimento dos fornecedores nas atividades de planejamento e tomada de decisão, obtendo subsídios para melhorar a qualidade da informação trocada. Esta atividade, além de permitir melhorar os níveis de confiança e comprometimento, proporcionaria elementos para definir ações conjuntas para atuar sobre o maior fator de insatisfação verificado neste estudo: o suporte e serviços insatisfatórios prestados pelos parceiros que tem gerado resultados negativos no atendimento aos clientes.

O desgaste da relação com os parceiros pode ser atribuído também pela a forma como os conflitos são tratados. Pelo que foi apurado neste estudo, há predominância do estilo de dominação, o que significa ações unilaterais para forçar uma solução, sem considerar os interesses da outra parte, caracterizando uma orientação ganha-perde que afeta negativamente o relacionamento.

No mesmo patamar de utilização, aparece o estilo de compromisso no trato dos conflitos, o qual mostra preocupação com a outra parte ao buscar uma solução de meio termo. No entanto, as soluções encontradas por esta abordagem são paliativas, pois induzem a que as partes iniciem a negociação com reivindicações acima de seu real interesse já que sabem de antemão que terão que ceder para chegar a um bom termo e, portanto, não eliminam totalmente o desgaste do relacionamento.

A melhoria do processo de comunicação e a elevação dos níveis de confiança e comprometimento entre as partes abririam caminho para uma ação colaborativa na resolução de conflitos, o que tenderia a aumentar a satisfação com o relacionamento.

A utilização do informante-chave para a execução desta pesquisa teve como base o fato de que se trata de pessoa que tem amplo conhecimento do relacionamento de parceria em questão. No entanto, muitas outras pessoas, em diferentes níveis hierárquicos, interagem com os parceiros e podem influenciar o relacionamento. Dessa forma, a exploração de outras perspectivas pode ser útil para obter um melhor entendimento dos fatores envolvidos na parceria, o que pode ser pensado para estudos futuros. 
Este estudo explorou a visão do fabricante quanto ao relacionamento com o fornecedor, o que sugere que um estudo complementar com a visão de ambos os lados viria a enriquecer o entendimento do relacionamento, já que atitudes e percepções de um lado influenciam o outro e expectativas não explicitadas podem distorcer análises e resultados. Além disso, a confrontação de visões permitiria evidenciar de forma mais clara problemas de comunicação, interpretação e transparência.

Por ser um estudo de caso, os resultados referem-se ao contexto analisado não podendo ser extrapolados, apesar de terem sido encontradas similaridades com trabalhos anteriores que aplicaram o modelo em amostras representativas de segmentos e ambientes mais amplos.

Uma perspectiva interessante, apesar da dificuldade de acesso, seria a realização de um estudo de casos múltiplos, dentro da indústria aeronáutica, o que significaria uma amplitude mundial e permitiria confrontar nuances de ambientes e culturas diferentes, possibilitando comparações sobre diversos ângulos.

Como o modelo utilizado neste estudo trata de características comportamentais e de relacionamento, é importante registrar que existem outras dimensões possíveis de análise não abordadas neste estudo, envolvendo aspectos antropológicos e psicológicos tais como: cultura, valores e crenças das empresas, o que influencia na motivação e engajamento para desenvolver relacionamentos nos moldes do modelo apresentado.

Esta pesquisa, por ser de caráter exploratório, buscou identificar a presença ou não dos atributos, previstos no modelo conceitual de referência, em um relacionamento de parceria específico, não tendo pretensão e nem elementos que pudessem subsidiar análises mais profundas de causas e motivos do que foi detectado, para o que seria necessária uma outra concepção de pesquisa - explanatória.

\subsection{Conclusões}

O presente trabalho permitiu verificar os fatores presentes e forneceu subsídios para um melhor entendimento do relacionamento de parceria estudado, apresentando um modelo que 
pode ser uma boa referência para direcionar ações para melhorar a parceria entre a Embraer e os fornecedores do projeto EMB-170/190.

O resultado do estudo gera a percepção de que, embora tenha havido uma evolução no relacionamento fabricante-fornecedor em direção ao modelo colaborativo, ainda existe um bom caminho a ser trilhado pela empresa para atingir a relação de parceria preconizada pelo modelo referencial utilizado neste trabalho.

Sob o ponto de vista de implicações gerenciais, este estudo ofereceu idéias para entender melhor as características presentes em parcerias bem sucedidas e sua relação com a satisfação do fabricante, bem como indicativos quanto ao desenvolvimento de relacionamentos mais eficazes que possam levar a obter vantagem competitiva.

Colocando uma perspectiva mais ampla no processo evolutivo do relacionamento da Embraer com os fornecedores, este estudo permite argumentar que o modelo de relacionamento a ser utilizado deve ser adaptado de acordo com o contexto vigente, as características do produto e do projeto, a situação de mercado e a capacitação técnica, econômica e operacional da cadeia de suprimentos. 


\section{REFERÊNCIAS}

AMATO NETO, João. Reestruturação industrial, terceirização e redes de subcontratação. Revista de Administração de Empresas - RAE. São Paulo, v.35, n.2, p. 33-42, Mar./Abr. 1995.

ANDERSON, Erin; WEITZ, Barton. The use of pledges to build and sustain commitment in distribution channels. Journal of Marketing Research; 29, 1; pg. 18; 1992.

ANDERSON, James C.; NARUS, J. A. A model of distributor firm and manufacturer firm working partnerships. Journal of Marketing; 54, 1; pg. 42; 1990.

BENSAOU, M. Portfolios of buyer-supplier relationships. Sloan Management Review; 40, 4, pg. 35; Summer 1999.

BENTON, W.C.; MALONI, Michael. The influence of power driven buyer/seller relationships on supply chain satisfaction. Journal of Operations Management; 23, pg. 1$22,2005$.

BOOZ ALLEN HAMILTON. Supply Chain Management at 21: The Hard Road to Adulthood. 2003.

BOWERSOX, Donald J. et al. How to master cross-enterprise collaboration. Supply Chain Management Review; pg. 18; July/August 2003.

BRONZO, Marcelo. Relacionamentos colaborativos em redes de suprimentos. Revista de Administração de Empresas - RAE; v. 44; Edição especial MG; p. 61-73; Set-Dez/2004.

CARONA, Natércia Filipe Mendeiros. Gestão de relacionamentos em redes de suprimentos - Um estudo de caso na rede de soja no Brasil. São Paulo, 2004. Dissertação (Mestrado em Administração de Empresas) - Escola de Administração de Empresas de São Paulo, Fundação Getúlio Vargas.

CASSIOLATO, José E. et al. Transfer of technology for successful integration into the global economy: A case study of Embraer in Brazil. UNCTAD/ITE/IPC/Misc.20. United Nations; New York and Geneva, 2002.

CENTRO TÉCNICO AEROESPACIAL - CTA. Histórico. Disponível em: $<$ http://www.cta.br>. Acesso em: 20/05/2006.

CHOI, Thomas Y.; ROSSETTI, Christian. On the dark side of strategic sourcing: experiences from the aerospace industry. Academy of Management Executive; Vol. 19, N. 1, 2005. 
CHOPRA, Sunil; MEINDL, Peter. Supply chain management: strategy, planning, and operation. Upper Saddle River, New Jersey: Prentice-Hall, 2001.

CHRISTOPHER, Martin. Logística e gerenciamento da cadeia de suprimentos. Tradução: Francisco M. Leite. São Paulo: Pioneira, 1997. Tradução de: Logistics and supply chain management.

COASE, R.H. The nature of the firm. Economica, New series, Vol. 4, N. 16, 386-405; Nov. 1937.

COOPER, Martha C. et al. Meshing multiple alliances. Journal of Business Logistics; 18, 1; pg. $67 ; 1997$.

CORRÊA, Henrique L.; CORRÊA, Carlos A. Redes de operações na cadeia de valor. In: Administração da produção e operações: manufatura e serviços: uma abordagem estratégica. São Paulo: Atlas, 2004.

COX, Andrew et al. Supply chain and power regimes: toward an analytic framework for managing extended networks of buyer and supplier relationships. Journal of Supply Chain Management; 37, 2; pg. 28; Spring 2001.

DAGNINO, Renato. Competitividade da indústria aeronáutica. Estudo da Competitividade da Indústria Brasileira. Nota Técnica Setorial; Instituto de Economia da Universidade de Campinas, 1993.

DI SERIO, Luiz Carlos; SAMPAIO, Mauro. Projeto da cadeia de suprimentos: uma visão dinâmica da decisão fazer versus comprar. Revista de Administração de Empresas - RAE; v. 41, n. 1; p. 54-66; Jan./Mar. 2001.

DOZ, Yves L.; HAMEL, Gary. A vantagem das alianças: a arte de criar valor através das parcerias. Tradução: Bázan Tecnologia e Lingüística. Rio de Janeiro: Qualitimark, 2000. Tradução de: Alliance advantage.

DUARTE, Margarida; DAVIES, Gary. Testing the conflict-performance assumption in business-to-business relationships. Industrial Marketing Management; 32; 91-99; 2003.

DUSSAUGE, Pierre; GARRETTE, Bernard. Determinants of success in international strategic alliances: evidence from the global aerospace industry. Journal of International Business; Vol. 26, Issue 3; pg. 505; 1995.

DWYER, F. Robert et al. Developing buyer-seller relationships. Journal of Marketing; 51, 2; pg. 11; Apr 1987. 
DYER, Jeffrey H. How Chrysler created an american keiretsu. Harvard Business Review; July-August 1996.

EISENHARDT, Kathleen M. Building theories from case study research. Academy of Management Review; 14, 4; pg. 532; Oct 1989.

ELLRAM, Lisa M. Partnering pitfalls and success factors. International Journal of Purchasing and Materials Management; 31, 2; pg. 35; Spring 1995.

ELLRAM, Lisa M.; EDIS, Owen R.V. A case study of successful partnering implementation. International Journal of Purchasing and Materials Management; 32, 4; pg. 20; Fall 1996.

ELLRAM, Lisa M.; HENDRICK, Thomas E. Partnering characteristics: a dyadic perspective. Journal of Business Logistics; 16, 1; pg. 41; 1995.

EMPRESA BRASILEIRA DE AERONÁUTICA - EMBRAER. Histórico. São José dos Campos, 2006. Disponível em: <http://www.embraer.com.br>. Acesso em: 05/01/2006.

EMPRESA BRASILEIRA DE AERONÁUTICA - EMBRAER. Adensamento da cadeia produtiva: a visão da Embraer. In: SEMINÁRIO BNDES - O ADENSAMENTO DA CADEIA PRODUTIVA DA INDÚSTRIA AERONÁUTICA, 2004, Rio de Janeiro. Disponível em: <http://www.bndes.gov.br>. Acesso em: 05/10/2005.

ENVIRONMENTAL PROTECTION AGENCY - EPA. Profile of the Aerospace Industry. Disponível em: <http://www.epa.gov>. Acesso em: 10/06/2006.

ESPOSITO, Emilio. Strategic alliances and internationalization in the aircraft manufacturing industry. Technological Forecasting and Social Change; 71; 443-468; 2004.

EUROPEAN ASSOCIATION OF AEROSPACE INDUSTRIES - AECMA. Industrial and structural issues; January 2004. Disponível em: <http://www.aecma.org>. Acesso em: 20/05/2005.

FACHIN, Odília. Fundamentos de Metodologia. São Paulo: Saraiva, 2005 (4a ed.).

FINE, Charles H. Mercados em evolução continua. Tradução: Afonso Celso da Cunha Serra. Rio de Janeiro: Campus, 1999. Tradução de: Clockspeed.

FISHER, Marshall L. What is the right supply chain for your product. Harvard Business Review, March-April 1997.

FLAHERTY, M. Therese. Global operations management. New York: McGraw-Hill, 1996. 
FLYNN, Barbara B. et al. Empirical research methods in operations management. Journal of Operations Management; Vol. 9, N. 2, pp. 250-284; April 1990.

FREITAS, Henrique et al. O método de pesquisa survey. Revista de Administração; v. 35, n. 3 ; p. 105-112; Jul/Set 2000.

GANESAN, Shankar. Determinants of long-term orientation in buyer-seller relationships. Journal of Marketing; 58, 2; pg. 1; 1994.

GAO, Tao et al. Reducing buyer decision-making uncertainty in organizational purchasing: can supplier trust, commitment, and dependence help? Journal of Business Research; 58; pg. 397-405; 2005.

GIUNTA, Anna. Supplier relations in commercial aircraft industry: the case of Alenia in southern Italy. In: INTERNATIONAL COUNCIL FOR SMALL BUSINESS, 1999, Nápoles. Naples Conference Proceedings.

GLAISTER, Keith W.; BUCKLEY, Peter J. Measures of performance in UK international alliances. Organization Studies; 19, 1; pg. 89; 1998.

GRAHAM, Pauline. Saying "No" to compromise; "Yes" to integration. Journal of Business Ethics; 17, 9/10; pg. 1007; Jul 1998.

GRAHAM, T. Scott et al. The long-term strategic impact of purchasing partnerships. International Journal of Purchasing and Materials Management; 30, 4; pg. 13; Fall 1994.

GRISI, Celso Claudio de Hildebrand e; RIBEIRO, Aurea Helena Puga. Suppliermanufacturer relantionships in the Brazilian auto industry: an exploration of distinctive elements. Journal of Business \& Industrial Marketing; Vol. 19, N. 6, pp. 415-420; 2004.

GULATI, Ranjay. Does familiarity breed trust? The implications of repeated ties for contractual choice in alliances. Academy of Management Journal; 38, 1; pg. 85; Feb 1995.

GULATI, Ranjay. Alliances and Networks. Strategic Management Journal; 19, 4; pg. 293317; Apr 1998.

HARLAND, Christine M. Supply Chain Management: relationships, chains and networks. British Journal of Management; Vol. 7, Special Issue, p. 63-80; March 1996.

HEIDE, Jan B.; JOHN, George. Alliances in industrial purchasing: the determinants of joint action in buyer-supplier relationships. Journal of Marketing Research; Vol. XXVII, pg. 2436; February 1990. 
HELPER, Susan R.; SAKO Mari. Supplier relations in Japan and the United States: are they converging? Sloan Management Review; 36, 3; pg. 77; Spring 1995.

HENSLEY, Rhonda L. A review of operations management studies using scale development techniques. Journal of Operations Management; 17, pg. 343-358; 1999.

HIBBARD, Jonathan D. et al. Examining the impact of destructive acts in marketing channel relationships. Journal of Marketing Research; 38, 1; pg. 45; Feb 2001.

HUMPHRIES, Andrew S.; WILDING, Richard. Partnerships in UK defense procurement. International Journal of Logistics Management; 12, 1; pg. 83; 2001.

INSTITUTE FOR SUPPLY MANAGEMENT - ISM. ISM 2002 Benchmarking Study. Disponível em: <http://www.ism.org>. Acesso em: 26/10/2005.

JAP, Sandy D. Pie-expansion efforts: collaboration processes in buyer-supplier relationships. Journal of Marketing Research; 36, 4; pg. 461; Nov 1999.

JAP, Sandy D.; Anderson, Erin. Safeguarding interorganizational performance and continuity under ex post opportunism. Management Science; 49, 12; pg. 1684; Dec 2003.

JARILLO, Juan Carlos. Strategic networks: creating the borderless organization. Oxford: Butterworth Heinemann, 1993.

JOHNSON, Julie T. et al. Factors associated with customer willingness to refer leads to salespeople. Journal of Business Research; 56; pg. 257-263; 2003.

JOHNSON, Jean L.; SOHI, Ravipreet S. The influence of firm predispositions on interfirm relationship formation in business markets. International Journal of Research in Marketing; 18; pg. 299-318; 2001.

KALE, Prashant et al. Alliance capability, stock market response, and long-term alliance success: the role of the alliance function. Strategic Management Journal; 23, 8, pg. 747; Aug 2002.

KRAUSE, Daniel R. The antecedents of buying firms' efforts to improve suppliers. Journal of Operations Management; 17, pg. 205-224; 1999.

KUMAR, Nirmalya et al. The effects of perceived interdependence on dealer attitudes. Journal of Marketing Research; 32, 3; pg. 348; 1995.

LAKATOS, Eva Maria; MARCONI, Marina de Andrade. Fundamentos de Metodologia Científica. São Paulo: Atlas, 1991 ( $3^{\text {a }}$ ed.). 
LAMBERT, Douglas M. et al. So you think you want a partner? Marketing Management; 5, 2; pg. 24; Summer 1996.

LAMBERT, Douglas M. et al. Building successful logistics partnerships. Journal of Business Logistics; 20, 1; pg. 165; 1999.

LAMBERT, Douglas M.; KNEMEYER, A. Michael. Juntos, no mesmo barco. Harvard Business Review; Dezembro 2004 (A cadeia de suprimentos do século 21).

LANDEROS, Robert et al. Maintaining buyer-supplier partnerships. International Journal of Purchasing and Materials Management; 31, 3; pg. 3; Summer 1995.

LANGFIELD-SMITH, Kim; GREENWOOD, Michelle R. Developing co-operative buyersupplier relationships: a case study of Toyota. Journal of Management Studies; 35:3; May 1998.

LEE, Don Y. Power, conflict, and satisfaction in IJV supplier-Chinese distributor channels. Journal of Business Research; 52; pg. 149-160; 2001.

LEMKE, Fred et al. Investigating the meaning of supplier-manufacturer partnerships: an exploratory study. International Journal of Physical Distribution \& Logistics Management; Vol. 33, N. 1, pp. 12-35; 2003.

LIKER, Jeffrey K.; CHOI, Thomas Y. Building deep supplier relationships. Harvard Business Review, December 2004.

LIN, Xiaohua; GERMAIN, Richard. Sustaining satisfactory joint venture relationships: The role of conflict resolution strategy. Journal of International Business Studies; 29, 1, pg. 179; First Quarter 1998.

LINDGREEN, Adam. Trust as a valuable strategic variable in the food industry: different types of trust and their implementation. British Food Journal; 105, 6/7, pg. 310; 2003.

LUMMUS, Rhonda R.; VOKURKA, Robert J. Defining supply chain management: $a$ historical perspective and practical guidelines. Industrial Management \& Data Systems; 99/1, pg. 11-17; 1999.

LUSCH, Robert F.; BROWN, James R. Interdependency, contracting, and relational behavior in marketing chanells. Journal of Maketing; 60, 4; pg. 19; Oct 1996.

MALHOTRA, Naresh K.; GROVER, V. An assessment of survey research in POM: from constructs to theory. Journal of Operations Management; 16, pg. 407-425; 1998.

MALHOTRA, Naresh K. Pesquisa de Marketing. Porto Alegre: Bookman, 2001. 
MARTINS, Denise Maria; GONÇALVES, Marilson Alves. Eficácia dos indicadores de desempenho na cadeia de fornecimento automotivo. In: SIMPÓSIO DE ADMINISTRAÇÃO DA PRODUÇÃO, LOGÍSTICA E OPERAÇÕES INTERNACIONAIS - SIMPOI, 7, 2004, São Paulo. Anais... São Paulo: FGV, 2004. CD-ROM.

MEDINA-MUÑOZ, Diego; GARCÍA-FALCÓN, Juan Manuel. Successful relationships between hotels and agencies. Annals of Tourism Research; Vol. 27, No. 3, pp. 737-762; 2000 .

MENTZER, John T. et al. The nature of interfirm partnering in supply chain management. Journal of Retailing; Vol. 76, No. 4, pp. 549-568; 2000.

MENTZER, John T. (Org.). Supply chain management. Thousand Oaks, California: Sage Publications, 2001.

METCALF, L. E. et al. Buyer-seller relationships: an application of the IMP interaction model. European Journal of Marketing; Vol. 26, No. 2, pp. 27-47; 1992.

MOHR, Jakki J.; SPEKMAN, Robert E. Characteristics of partnership success: partnership atributes, communication behavior and conflict resolution techniques. Strategic Management Journal; 15, 2, pg. 135; Feb 1994.

MONCZKA, Robert M. et al. Predictors of relationships among buying and supplying firms. International Journal of Physical Distribution \& Logistics Management; Vol. 25, № 10 , pp. 45-59; 1995.

MONCZKA, Robert M. et al. Purchasing and supply chain management. Cincinnati, Ohio: South-Western College Publishing, 1998a.

MONCZKA, Robert M. et al. Success factors in strategic supplier alliances: the buying company perspective. Decision Sciences; 29, 3; pg. 553; Summer 1998b.

MOORE, Kevin R.; CUNNINGHAM III, William A. Social exchange behavior in logistics relationships: a shipper perspective. International Journal of Physical Distribution \& Logistics Management; Vol. 29, №. 2, pp. 103-121; 1999.

MORGAN, Robert M.; HUNT, Shelby D. The commitment-trust theory of relationship marketing. Journal of Marketing; 58, 3; pg. 20; Jul 1994.

NIOSI, Jorge; ZHEGU, Majlinda. Aerospace clusters: local or global knowledge spillovers? Industry and Innovation; 12, 1; pg. 5; Mar 2005. 
OLIVEIRA, Silvio Luiz de. Tratado de Metodologia Científica: projetos de pesquisa, TGI, TCC, monografias, dissertações e teses. São Paulo: Pioneira, 2002.

PESTANA, Maria Helena; GAGEIRO, João Nunes. Análise de dados para ciências sociais: a funcionalidade do SPSS. Lisboa: Edições Sílabo, 2000.

PETERSEN, Kenneth J. et al. An examination of collaborative planning effectiveness and supply chain performance. Journal of Supply Chain Management; 41, 2; pg. 14; Spring 2005.

RAHIM, M. Afzalur. Toward a theory of managing organizational conflict. International Journal of Conflict Management; 13, 3; pg. 206; 2002.

RAMSAY, J. Problems with empiricism and philosophy of science: implications for purchasing research. European Journal of Purchasing \& Supply Management; 4; pg. 163-173; 1998.

ROXENHALL, Tommy; GHAURI, Pervez. Use of written contract in log-lasting business relationships. Industrial Marketing Management; 33; pg. 261-268; 2004.

RUNGTUSANATHAM, M. Johnny et al. Survey research in operations management: historical analyses. Journal of Operations Management; 21; pg. 475-488; 2003.

SCHMITT, Burkard. From co-operation to integration: defense and aerospace industries in Europe. Institute for Security Studies of Western European Union; Chaillot Paper 40; Paris; July 2000.

SIMCHI-LEVI, David et al. Designing and managing the supply chain: concepts, strategies, and case studies. Boston: McGraw-Hill, 2000.

STAKE, Robert E.. The art of case study research. Thousand Oaks, California: Sage Publications, Inc., 1995.

STURGEON, Timothy J. How do we define value chains and production networks? IDS Bulletin; vol. 32, n 3; 2001 (Massachussetz Institute of Technology - MIT).

TAN, Heah Choon. A framework of supply chain management literature. European Journal of Purchasing \& Supply Management; 7, 39-48; 2001.

THORELLI, Hans B. Networks: between markets and hierarchies. Strategic Management Journal; 7, 1, pg. 37-51; Jan-Feb 1986.

WEBSTER, Frederick E., Jr. The changing role of marketing in the corporation. Journal of Marketing; 56, 4; pg. 1; Oct 1992. 
WEITZ, Barton A.; BRADFORD, Kevin D. Personal selling and sales management: $a$ relationship marketing perspective. Journal of the Academy of Marketing Science; 27, 2; pg. 241; 1999.

WILSON, D. T. An integrated model of buyer-seller relationships. Journal of the Academy of Marketing Science; 23, 4; pg. 335; 1995.

WOMACK, James P. et al. A máquina que mudou o mundo. Rio de Janeiro: Campus, 1992.

WREN, Brent M.; SIMPSON, James T. A dyadic model of relationships in organizational buying: a synthesis of research results. Journal of Business \& Industrial Marketing; Vol. 11, No. 3/4, pp. 63-79; 1996.

YIN, R. K. Case study research: design and methods. $2^{\text {nd }}$ ed. Thousand Oaks, California: Sage Publications, Inc., 1994. (Applied social research methods series; v. 5).

REFERÊNCIAS ADICIONAIS (Bibliografia consultada, mas não citada)

ANDERSON, James C. et al. Dyadic business relantionships whitin a business network context. Journal of Marketing; 58, 4; pg. 1; Oct 1994.

BOWERSOX, Donald J.; CLOSS, David J. Logistical management: the integrated supply chain process. New York: McGraw Hill, 1996.

BRAGG, Richard; KUMAR, Sameer. Building strategic partnerships. Industrial Engineer; 35, 6, pg. 39; Jun 2003.

CROXTON, Keely L. et al. The supply chain management processes. International Journal of Logistics Management; 12, 2; pg. 13; 2001.

DOZ, Yves L. The evolution of cooperation in strategic alliances: Initial Conditions or Learning Processes? Strategic Management Journal; 17, Special Issue; pg. 55; Summer 1996.

ELLRAM, Lisa M. The supplier selection decision in strategic partnerships. International Journal of Purchasing and Materials Management; 26, 4; pg. 8; Fall 1990.

FYNES, Brian et al. The impact of supply chain relationship dynamics on manufacturing performance. International Journal of Operations \& Production Management; Vol. 25, N. 1, pp. 6-19; 2005. 
GASPARETTO, Valdirene. Proposta de uma sistemática para avaliação de desempenho em cadeias de suprimentos. Florianópolis, 2003. Tese (Doutorado em Engenharia de Produção) - Universidade Federal de Santa Catarina.

HARLAND, Christine M. et al. A taxonomy of supply networks. Journal of Supply Chain Management; 37, 4, pg. 21; Fall 2001.

HART, Christopher W.; JOHNSON Michael D. A framework for developing trust relationships. Marketing Management; 8, 1, pg. 20; Spring 1999.

HINGLEY, Martin. Relationship management in the supply chain. International Journal of Logistics Management; 12, 2; pg. 57; 2001.

JARILLO, Juan Carlos. On strategic networks. Strategic Management Journal; 9, 1, pg. 31; Jan/Feb 1988.

KLTZLE, Marcelo Cabus. Alianças estratégicas: conceito e teoria. Revista de Administração Contemporânea - RAC; v. 6, n. 1; pg. 85-104; Já./Abr. 2002.

LAMMING, Richard et al. Developing the concept of transparency for use in supply relationships. British Journal of Management, Vol. 15, 291-302; 2004.

LAMMING, Richard C. et al. Transparency in supply relationships: concept and practice. Journal of Supply Chain Management; 37, 4, pg. 4; Fall 2001.

MITCHELL, Will; SINGH, Kulwant. Survival of businesses using collaborative relationships to commercialize complex goods. Strategic Management Journal; 17, 3, pg. 169; Mar 1996.

MOHR, Jakki J.; SPEKMAN, Robert E. Perfecting partnerships. Marketing Management; 4, 4, pg. 34; Winter/Spring 1996.

MÖLLER, Morten M. et al. Managing buyer-supplier relationships and inter-organizational competence development. Integrated Manufacturing Systems, 14/4, pg. 369-379; 2003.

NIETO, Mariano et al. The evolution of operations management contents: an analysis of the most relevant textbooks. Industrial Management \& Data Systems, 99/8, pg. 345-352; 1999.

STEVENS, James P. Applied multivariate statistics for the social sciences. $4^{\text {th }}$ ed. Mahwah, New Jersey: Lawrence Erlbaum Associates, Inc., 2002.

UNIVERSIDADE DE SÃO PAULO - USP. Manual do mestrando e doutorando da FEA. São Paulo, Julho de 2004.

WHIPPLE, Judith Schmitz; GENTRY, Julie J. A network comparison of alliance motives and achievements. Journal of Business \& Industrial Marketing; Vol. 15, No. 5, pp. 301-322; 2000. 
ZSIDISIN, George A.; ELLRAM, Lisa M. Activities related to purchasing and supply management involvement in supplier alliances. International Journal of Physical Distribution \& Logistics Management; Vol. 31, N. 9, pp. 629-646; 2001. 


\section{APÊNDICES}

APÊNDICE 1: INSTRUMENTO DE COLETA DE INFORMAÇÕES APÊNDICE 2: INSTRUMENTO DE COLETA DE DADOS APÊNDICE 3: DADOS DEMOGRÁFICOS DOS RESPONDENTES APÊNDICE 4: TABELAS DE FREQUÊNCIA PARA AS CARACTERÍSTICAS APÊNDICE 5: TABELAS DE CONTINGÊNCIA PARA A SATISFAÇÃO GERAL APÊNDICE 6: TABELAS DE CONTINGÊNCIA ENTRE CARACTERÍSTICAS 


\section{APÊNDICE 1}

\section{INSTRUMENTO DE COLETA DE INFORMAÇÕES}

Este instrumento de pesquisa trata das características presentes nos relacionamentos de parceria entre fabricante e fornecedor.

Estas informações serão mantidas confidenciais e sem explicitação dos envolvidos e fazem parte de um estudo para compreender os atributos determinantes de parcerias bem sucedidas.

Responder às questões que seguem, colocando a sua visão quanto à formação da parceria com os fornecedores para atender ao programa 0170/0190. Caso queira destacar outros aspectos relevantes que extrapolem as perguntas apresentadas, incluir no tópico "Comentários".

9) Como você define "parceria" no contexto do programa 0170/0190?

10) Qual a abrangência dessa parceria? (Pesquisa, Tecnologia, Desenvolvimento de produto, Projeto, Finanças, Planejamento colaborativo, outros).

11) Quais os objetivos desta parceria?

12) Quais os fatores/critérios utilizados na escolha dos parceiros do programa 0170/0190?

13) Existiam metas estratégicas e/ou quantitativas? Quais?

14) Como medir os resultados alcançados e avaliar se a parceria foi bem sucedida?

15) O que diferencia "parceiro" de "fornecedor" neste contexto? (aspectos financeiros, aspectos contratuais, nível de comunicação, atributos do relacionamento).

16) Quais as similaridades e diferenças com a "parceria" do programa 0145 ?

\section{Comentários:}

Obs.: preferencialmente, suas respostas devem abordar o assunto de maneira geral, mas caso haja algum viés específico (tecnologia, grupo/tipo de fornecedor, fase do programa, etc), favor explicitar nas próprias respostas ou incluir no tópico "Comentários". 


\section{APÊNDICE 2}

\section{INSTRUMENTO DE COLETA DE DADOS}

Este instrumento de pesquisa trata de características comportamentais de relacionamentos de parceria entre fabricante e fornecedor e faz parte de um estudo para compreender os atributos determinantes de parcerias bem sucedidas.

Para responder, considere o relacionamento entre a sua empresa e o parceiro pelo qual você é responsável pela gestão, dentro do programa 0170/0190, e assinale o grau de concordância ou discordância que melhor descreve a sua opinião sobre as afirmações apresentadas.

Sua resposta deve estar baseada em uma visão objetiva e abrangente/estratégica do relacionamento com o parceiro no programa 0170/0190, evitando avaliar com referência a uma situação pontual/específica.

As respostas serão tratadas como confidenciais e sem a explicitação dos envolvidos, sendo utilizadas para análise estatística.

\section{$\underline{\text { Parte A }}$ - Caracterizacão do respondente}

Estas informações serão utilizadas apenas para catalogação e estatística, sem explicitar os envolvidos.

Nome:

Parceiro:

Tempo de experiência em Suprimentos:

Tempo de empresa:

Tempo como gestor deste parceiro: 


\section{$\underline{\text { Parte B }}$ - $\underline{\text { Atributos da parceria }}$}

Este conjunto de assertivas avalia aspectos relativos à confiança, comprometimento, cooperação e dependência presentes nesta parceria.

Indique em que grau você concorda com as seguintes afirmações.

\begin{tabular}{|c|c|c|c|c|c|}
\hline \multirow{2}{*}{$\begin{array}{l}\text { 1. Podemos contar com este fornecedor para } \\
\text { executar ações eficazes em atendimento aos } \\
\text { objetivos da nossa empresa. }\end{array}$} & $\begin{array}{c}\text { Discordo } \\
\text { totalmente }\end{array}$ & Discordo & $\begin{array}{c}\text { Não discordo } \\
\text { nem concordo }\end{array}$ & Concordo & $\begin{array}{c}\begin{array}{c}\text { Concordo } \\
\text { totalmente }\end{array} \\
\end{array}$ \\
\hline & & & & & \\
\hline $\begin{array}{l}\text { 2. Este fornecedor tem um forte senso de } \\
\text { lealdade para conosco. }\end{array}$ & & & & & \\
\hline $\begin{array}{l}\text { 3. Nossa empresa é dependente deste } \\
\text { fornecedor. }\end{array}$ & & & & & \\
\hline $\begin{array}{l}\text { 4. Nossa empresa procura cooperar com este } \\
\text { fornecedor de diversas formas. }\end{array}$ & & & & & \\
\hline $\begin{array}{l}\text { 5. Este fornecedor mostra-se disposto a fazer } \\
\text { investimento de longo prazo para dar suporte } \\
\text { a nossa empresa. }\end{array}$ & & & & & \\
\hline $\begin{array}{l}\text { 6. Este fornecedor tem um alto grau de } \\
\text { integridade. }\end{array}$ & & & & & \\
\hline 7. Seria difícil substituir este fornecedor. & & & & & \\
\hline $\begin{array}{l}\text { 8. Quando surge algum problema, tentamos } \\
\text { resolvê-lo em conjunto. }\end{array}$ & & & & & \\
\hline $\begin{array}{l}\text { 9. Teríamos um alto custo no caso de perder } \\
\text { este fornecedor. }\end{array}$ & & & & & \\
\hline $\begin{array}{l}\text { 10. Este fornecedor cumpre com suas } \\
\text { promessas. }\end{array}$ & & & & & \\
\hline $\begin{array}{l}\text { Este fornecedor considera nosso } \\
\text { relacionamento como uma parceria de longo } \\
\text { prazo. }\end{array}$ & & & & & \\
\hline $\begin{array}{l}\text { 12. Nossa empresa ajuda este fornecedor de } \\
\text { diversas formas, quando solicitado por ele. }\end{array}$ & & & & & \\
\hline $\begin{array}{l}\text { 13. Nossa empresa planeja, com frequiência, } \\
\text { atividades, projetos ou programas conjuntos } \\
\text { com este fornecedor. }\end{array}$ & & & & & \\
\hline $\begin{array}{l}\text { 14. Este fornecedor é honesto quando surgem } \\
\text { problemas causados por ele. }\end{array}$ & & & & & \\
\hline $\begin{array}{l}\text { 15. Este fornecedor mostra-se disposto a } \\
\text { dedicar pessoas e recursos necessários para } \\
\text { nos tornar clientes satisfeitos. }\end{array}$ & & & & & \\
\hline $\begin{array}{l}\text { 16. Este fornecedor é dependente de nossa } \\
\text { empresa. }\end{array}$ & & & & & \\
\hline $\begin{array}{l}\text { 17. Este fornecedor não faz reivindicações } \\
\text { infundadas. }\end{array}$ & & & & & \\
\hline $\begin{array}{l}\text { 18. Este fornecedor não dará preferência a } \\
\text { outro cliente em detrimento de nossa } \\
\text { empresa. }\end{array}$ & & & & & \\
\hline $\begin{array}{l}\text { 19. Este fornecedor teria um alto custo se nos } \\
\text { perdesse como cliente. }\end{array}$ & & & & & \\
\hline $\begin{array}{l}\text { 20. Este fornecedor ajuda nossa empresa de } \\
\text { diversas formas, quando solicitamos. }\end{array}$ & & & & & \\
\hline
\end{tabular}




\section{$\underline{\text { Parte C - Comunicação }}$}

Este conjunto de assertivas aborda as características do compartilhamento de informação entre sua empresa e este parceiro.

Indique em que grau você concorda com as seguintes afirmações.

\begin{tabular}{|l|l|l|l|l|l|}
\hline $\begin{array}{l}\text { 21. Este fornecedor compartilha informação } \\
\text { relevante (crítica e proprietária) com nossa } \\
\text { empresa. }\end{array}$ & $\begin{array}{c}\text { Discordo } \\
\text { totalmente }\end{array}$ & Discordo & $\begin{array}{c}\text { Não discordo } \\
\text { nem concordo }\end{array}$ & Concordo & $\begin{array}{c}\text { Concordo } \\
\text { totalmente }\end{array}$ \\
\hline $\begin{array}{l}\text { 22. Nossa empresa busca, ativamente, } \\
\text { aconselhamento com este fornecedor. }\end{array}$ & & & & \\
\hline $\begin{array}{l}\text { 23. Informamos este fornecedor sobre } \\
\text { mudanças necessárias com antecedência. }\end{array}$ & & & & & \\
\hline $\begin{array}{l}\text { 24. Este fornecedor participa de nossas } \\
\text { atividades de planejamento e } \\
\text { estabelecimento de metas que sejam } \\
\text { relevantes para nosso relacionamento. }\end{array}$ & & & & & \\
\hline $\begin{array}{l}\text { 25. Qualquer informação, que possa ajudar } \\
\text { a outra parte, espera-se que seja partilhada. }\end{array}$ & & & & \\
\hline $\begin{array}{l}\text { 26. Nossa empresa encoraja este fornecedor } \\
\text { a dar sugestões de melhoria. }\end{array}$ & & & & \\
\hline $\begin{array}{l}\text { 27. Nossa comunicação com este fornecedor } \\
\text { é adequada, acurada, crível, completa e no } \\
\text { tempo certo. }\end{array}$ & & & & \\
\hline $\begin{array}{l}\text { 28. É esperado que cada parceiro mantenha } \\
\text { outro informado sobre eventos e } \\
\text { mudanças que possam afetar a outra parte. }\end{array}$ & & & & & \\
\hline $\begin{array}{l}\text { 29. Nossa empresa compartilha informação } \\
\text { relevante (crítica e proprietária) com este } \\
\text { fornecedor. }\end{array}$ & & & & & \\
\hline $\begin{array}{l}\text { 30. Nossa empresa participa das atividades } \\
\text { de planejamento e estabelecimento de metas } \\
\text { deste fornecedor que sejam relevantes para } \\
\text { nosso relacionamento. }\end{array}$ & & & & \\
\hline
\end{tabular}

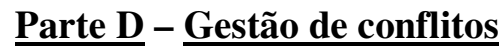

Indique com que freqüência é utilizada cada uma das seguintes formas de solução de conflitos entre sua empresa e este parceiro.

\begin{tabular}{|c|c|c|c|c|c|}
\hline & Nunca & Raramente & Às vezes & Frequentemente & Sempre \\
\hline $\begin{array}{l}\text { 31. Satisfazer o próprio interesse em } \\
\text { detrimento da outra parte. }\end{array}$ & & & & & \\
\hline $\begin{array}{l}\text { 32. Buscar em conjunto uma solução } \\
\text { integrativa (ganha-ganha). }\end{array}$ & & & & & \\
\hline $\begin{array}{l}\text { 33. Ignorar ou negar-se a reconhecer o } \\
\text { conflito. }\end{array}$ & & & & & \\
\hline 34. Ceder para satisfazer a outra parte. & & & & & \\
\hline 35. Chegar a um acordo de meio-termo. & & & & & \\
\hline
\end{tabular}




\section{Parte E - Satisfacão geral}

As afirmações tratam da satisfação geral com o relacionamento entre sua empresa e este parceiro.

Indique em que grau você concorda com as seguintes afirmações.

\begin{tabular}{|l|l|l|l|l|l|}
\hline & $\begin{array}{c}\text { Discordo } \\
\text { totalmente }\end{array}$ & Discordo & $\begin{array}{c}\text { Não discordo } \\
\text { nem concordo }\end{array}$ & Concordo & $\begin{array}{c}\text { Concordo } \\
\text { totalmente }\end{array}$ \\
\hline $\begin{array}{l}\text { 36. Estamos satisfeitos com nosso } \\
\text { relacionamento com este fornecedor. }\end{array}$ & & & & & \\
\hline $\begin{array}{l}\text { 37. Gostaríamos que outros fornecedores } \\
\text { nossos fossem como este. }\end{array}$ & & & & & \\
\hline $\begin{array}{l}\text { 38. Estamos satisfeitos em fazer negócio com } \\
\text { este fornecedor. }\end{array}$ & & & & & \\
\hline $\begin{array}{l}\text { 39. Gostaríamos de continuar nosso } \\
\text { relacionamento com este fornecedor no } \\
\text { futuro. }\end{array}$ & & & & \\
\hline $\begin{array}{l}\text { 40. Estamos satisfeitos com o suporte e } \\
\text { serviços recebidos deste fornecedor. }\end{array}$ & & & & & \\
\hline
\end{tabular}

\section{$\underline{\text { Parte F - Comentários e observacões }}$}

Utilize o espaço abaixo para colocar suas impressões quanto aos resultados alcançados com esta parceria, seus pontos fortes e fracos, e o que a diferencia dos relacionamentos tradicionais com outros fornecedores. 
APÊNDICE 3

DADOS DEMOGRÁFICOS DOS RESPONDENTES

Statistics

\begin{tabular}{|ll|r|r|r|}
\hline & $\begin{array}{c}\text { experiência } \\
\text { em } \\
\text { suprimentos }\end{array}$ & $\begin{array}{c}\text { tempo de } \\
\text { empresa }\end{array}$ & $\begin{array}{c}\text { tempo como } \\
\text { gestor }\end{array}$ \\
\hline N & Valid & 11 & 11 & 11 \\
Mean & Missing & 0 & 0 & 0 \\
Median & 9,273 & 5,709 & 2,327 \\
\hline
\end{tabular}

experiência em suprimentos

\begin{tabular}{|ll|r|r|r|r|}
\hline & & Frequency & Percent & Valid Percent & $\begin{array}{c}\text { Cumulative } \\
\text { Percent }\end{array}$ \\
\hline Valid & 5,0 & 1 & 9,1 & 9,1 & 9,1 \\
& 7,0 & 1 & 9,1 & 9,1 & 18,2 \\
& 3,0 & 3 & 27,3 & 27,3 & 45,5 \\
& 4,0 & 4 & 36,4 & 36,4 & 81,8 \\
& 11,0 & 1 & 9,1 & 9,1 & 90,9 \\
& 15,0 & 1 & 9,1 & 9,1 & 100,0 \\
& Total & 11 & 100,0 & 100,0 & \\
\hline
\end{tabular}


tempo de empresa

\begin{tabular}{|ll|r|r|r|r|}
\hline & & & & \multicolumn{2}{c|}{$\begin{array}{c}\text { Cumulative } \\
\text { Percent }\end{array}$} \\
\hline Valid & 3,0 & 1 & 9,1 & 9,1 & 9,1 \\
& 3,8 & 1 & 9,1 & 9,1 & 18,2 \\
4,0 & 2 & 18,2 & 18,2 & 36,4 \\
& Frequency & Percent & Valid Percent \\
6,5 & 1 & 9,1 & 9,1 & 45,5 \\
7,0 & 2 & 18,2 & 18,2 & 63,6 \\
7,5 & 2 & 18,2 & 18,2 & 81,8 \\
9,0 & 1 & 9,1 & 9,1 & 90,9 \\
& 1 & 9,1 & 9,1 & 100,0 \\
\hline
\end{tabular}

tempo como gestor

\begin{tabular}{|ll|r|r|r|r|}
\hline & Frequency & Percent & Valid Percent & $\begin{array}{c}\text { Cumulative } \\
\text { Percent }\end{array}$ \\
\hline Valid &, 8 & 1 & 9,1 & 9,1 & 9,1 \\
& 3 & 27,3 & 27,3 & 36,4 \\
& 1,0 & 2 & 18,2 & 18,2 & 54,5 \\
2,0 & 1 & 9,1 & 9,1 & 63,6 \\
2,5 & 1 & 9,1 & 9,1 & 72,7 \\
3,0 & 1 & 9,1 & 9,1 & 81,8 \\
3,8 & 1 & 9,1 & 9,1 & 90,9 \\
4,0 & 1 & 9,1 & 9,1 & 100,0 \\
4,5 & 11 & 100,0 & 100,0 & \\
Total & & &
\end{tabular}


APÊNDICE 4

TABELAS DE FREQUÊNCIA PARA AS CARACTERÍSTICAS

ATRIBUTOS DA PARCERIA

confiança 1

\begin{tabular}{|c|c|c|c|c|c|}
\hline & & Frequency & Percent & Valid Percent & $\begin{array}{l}\text { Cumulative } \\
\text { Percent }\end{array}$ \\
\hline \multirow{5}{*}{ Valid } & discordo & 2 & 18,2 & 18,2 & 18,2 \\
\hline & $\begin{array}{l}\text { não discordo nem } \\
\text { concordo }\end{array}$ & 2 & 18,2 & 18,2 & 36,4 \\
\hline & concordo & 6 & 54,5 & 54,5 & 90,9 \\
\hline & concordo totalmente & 1 & 9,1 & 9,1 & 100,0 \\
\hline & Total & 11 & 100,0 & 100,0 & \\
\hline
\end{tabular}

confiança 2

\begin{tabular}{|c|c|c|c|c|c|}
\hline & & Frequency & Percent & Valid Percent & $\begin{array}{c}\text { Cumulative } \\
\text { Percent }\end{array}$ \\
\hline Valid & $\begin{array}{l}\text { não discordo nem } \\
\text { concordo }\end{array}$ & 2 & 18,2 & 18,2 & 18,2 \\
\hline & concordo & 7 & 63,6 & 63,6 & 81,8 \\
\hline & concordo totalmente & 2 & 18,2 & 18,2 & 100,0 \\
\hline & Total & 11 & 100,0 & 100,0 & \\
\hline
\end{tabular}

confiança 3

\begin{tabular}{|c|c|c|c|c|c|}
\hline & & Frequency & Percent & Valid Percent & $\begin{array}{c}\text { Cumulative } \\
\text { Percent }\end{array}$ \\
\hline \multirow[t]{5}{*}{ Valid } & \multirow{3}{*}{$\begin{array}{l}\text { discordo totalmente } \\
\text { discordo } \\
\text { não discordo nem } \\
\text { concordo }\end{array}$} & 2 & 18,2 & 18,2 & 18,2 \\
\hline & & 4 & 36,4 & 36,4 & 54,5 \\
\hline & & 4 & 36,4 & 36,4 & 90,9 \\
\hline & concordo & 1 & 9,1 & 9,1 & 100,0 \\
\hline & Total & 11 & 100,0 & 100,0 & \\
\hline
\end{tabular}

confiança 4

\begin{tabular}{|c|c|c|c|c|c|}
\hline & & Frequency & Percent & Valid Percent & $\begin{array}{c}\text { Cumulative } \\
\text { Percent }\end{array}$ \\
\hline \multirow[t]{6}{*}{ Valid } & discordo totalmente & 1 & 9,1 & 9,1 & 9,1 \\
\hline & discordo & 3 & 27,3 & 27,3 & 36,4 \\
\hline & $\begin{array}{l}\text { não discordo nem } \\
\text { concordo }\end{array}$ & 2 & 18,2 & 18,2 & 54,5 \\
\hline & concordo & 4 & 36,4 & 36,4 & 90,9 \\
\hline & concordo totalmente & 1 & 9,1 & 9,1 & 100,0 \\
\hline & Total & 11 & 100,0 & 100,0 & \\
\hline
\end{tabular}


confiança 5

\begin{tabular}{|c|c|c|c|c|c|}
\hline & Frequency & Percent & Valid Percent & $\begin{array}{l}\text { Cumulative } \\
\text { Percent }\end{array}$ \\
\hline \multirow[t]{4}{*}{ Valid } & discordo & 4 & 36,4 & 36,4 & 36,4 \\
\hline & $\begin{array}{l}\text { não discordo } \\
\text { nem concordo }\end{array}$ & 2 & 18,2 & 18,2 & 54,5 \\
\hline & concordo & 5 & 45,5 & 45,5 & 100,0 \\
\hline & Total & 11 & 100,0 & 100,0 & \\
\hline
\end{tabular}

confiança unificada

\begin{tabular}{|ll|r|r|r|r|}
\hline & & & & Cumulative \\
& & Frequency & Percent & Valid Percent & Percent \\
\hline Valid & 1 & 2 & 18,2 & 20,0 & 20,0 \\
& 5 & 8 & 72,7 & 80,0 & 100,0 \\
& Total & 10 & 90,9 & 100,0 & \\
Missing & System & 1 & 9,1 & & \\
Total & & 11 & 100,0 & & \\
\hline
\end{tabular}

comprometimento 1

\begin{tabular}{|c|c|c|c|c|c|}
\hline & & Frequency & Percent & Valid Percent & $\begin{array}{l}\text { Cumulative } \\
\text { Percent }\end{array}$ \\
\hline \multirow[t]{5}{*}{ Valid } & discordo & 4 & 36,4 & 36,4 & 36,4 \\
\hline & $\begin{array}{l}\text { não discordo nem } \\
\text { concordo }\end{array}$ & 4 & 36,4 & 36,4 & 72,7 \\
\hline & concordo & 2 & 18,2 & 18,2 & 90,9 \\
\hline & concordo totalmente & 1 & 9,1 & 9,1 & 100,0 \\
\hline & Total & 11 & 100,0 & 100,0 & \\
\hline
\end{tabular}

comprometimento 2

\begin{tabular}{|c|c|c|c|c|c|}
\hline & & Frequency & Percent & Valid Percent & $\begin{array}{c}\text { Cumulative } \\
\text { Percent }\end{array}$ \\
\hline \multirow[t]{4}{*}{ Valid } & discordo & 3 & 27,3 & 27,3 & 27,3 \\
\hline & concordo & 6 & 54,5 & 54,5 & 81,8 \\
\hline & concordo totalmente & 2 & 18,2 & 18,2 & 100,0 \\
\hline & Total & 11 & 100,0 & 100,0 & \\
\hline
\end{tabular}


comprometimento 3

\begin{tabular}{|l|r|r|r|r|}
\hline & & & & Cumulative \\
& Frequency & Percent & Valid Percent & \begin{tabular}{c} 
Percent \\
\hline Valid
\end{tabular} discordo totalmente \\
não discordo nem & 1 & 9,1 & 9,1 & 9,1 \\
concordo & 1 & 9,1 & 9,1 & 18,2 \\
concordo & 6 & 54,5 & 54,5 & 72,7 \\
concordo totalmente & 3 & 27,3 & 27,3 & 100,0 \\
Total & 11 & 100,0 & 100,0 & \\
\hline
\end{tabular}

comprometimento 4

\begin{tabular}{|c|c|c|c|c|c|}
\hline & & Frequency & Percent & Valid Percent & $\begin{array}{l}\text { Cumulative } \\
\text { Percent }\end{array}$ \\
\hline \multirow[t]{5}{*}{ Valid } & discordo totalmente & 1 & 9,1 & 9,1 & 9,1 \\
\hline & discordo & 4 & 36,4 & 36,4 & 45,5 \\
\hline & $\begin{array}{l}\text { não discordo nem } \\
\text { concordo }\end{array}$ & 2 & 18,2 & 18,2 & 63,6 \\
\hline & concordo & 4 & 36,4 & 36,4 & 100,0 \\
\hline & Total & 11 & 100,0 & 100,0 & \\
\hline
\end{tabular}

comprometimento 5

\begin{tabular}{|c|c|c|c|c|c|}
\hline & & Frequency & Percent & Valid Percent & $\begin{array}{l}\text { Cumulative } \\
\text { Percent }\end{array}$ \\
\hline \multirow[t]{4}{*}{ Valid } & discordo totalmente & 2 & 18,2 & 18,2 & 18,2 \\
\hline & discordo & 7 & 63,6 & 63,6 & 81,8 \\
\hline & concordo & 2 & 18,2 & 18,2 & 100,0 \\
\hline & Total & 11 & 100,0 & 100,0 & \\
\hline
\end{tabular}

comprometimento unificado

\begin{tabular}{|c|c|c|c|c|c|}
\hline & & Frequency & Percent & Valid Percent & $\begin{array}{c}\text { Cumulative } \\
\text { Percent }\end{array}$ \\
\hline \multirow[t]{3}{*}{ Valid } & 1 & 3 & 27,3 & 30,0 & 30,0 \\
\hline & 5 & 7 & 63,6 & 70,0 & 100,0 \\
\hline & Total & 10 & 90,9 & 100,0 & \\
\hline Missing & System & 1 & 9,1 & & \\
\hline Total & & 11 & 100,0 & & \\
\hline
\end{tabular}


interdependência 1

\begin{tabular}{|c|c|c|c|c|c|}
\hline & & Frequency & Percent & Valid Percent & $\begin{array}{l}\text { Cumulative } \\
\text { Percent }\end{array}$ \\
\hline \multirow[t]{4}{*}{$\begin{array}{l}\text { Valid } \\
\end{array}$} & discordo & 2 & $\overline{18,2}$ & $\overline{18,2}$ & 18,2 \\
\hline & concordo & 2 & 18,2 & 18,2 & 36,4 \\
\hline & concordo totalmente & 7 & 63,6 & 63,6 & 100,0 \\
\hline & Total & 11 & 100,0 & 100,0 & \\
\hline
\end{tabular}

interdependência 2

\begin{tabular}{|ll|r|r|r|r|}
\hline & & & & Cumulative \\
& & Frequency & Percent & Valid Percent & Percent \\
\hline Valid & discordo & 2 & 18,2 & 18,2 & 18,2 \\
& concordo & 6 & 54,5 & 54,5 & 72,7 \\
& concordo totalmente & 3 & 27,3 & 27,3 & 100,0 \\
& 11 & 100,0 & 100,0 & \\
\hline
\end{tabular}

interdependêcnia 3

\begin{tabular}{|ll|r|r|r|r|}
\hline & & & & Cumulative \\
& & Frequency & Percent & Valid Percent & Percent \\
\hline Valid & concordo & 5 & 45,5 & 45,5 & 45,5 \\
& concordo totalmente & 6 & 54,5 & 54,5 & 100,0 \\
& 11 & 100,0 & 100,0 & \\
\hline
\end{tabular}

interdependência 4

\begin{tabular}{|c|c|c|c|c|c|}
\hline & & Frequency & Percent & Valid Percent & $\begin{array}{c}\text { Cumulative } \\
\text { Percent }\end{array}$ \\
\hline \multirow[t]{6}{*}{ Valid } & discordo totalmente & 1 & 9,1 & 9,1 & 9,1 \\
\hline & discordo & 4 & 36,4 & 36,4 & 45,5 \\
\hline & $\begin{array}{l}\text { não discordo nem } \\
\text { concordo }\end{array}$ & 3 & 27,3 & 27,3 & 72,7 \\
\hline & concordo & 2 & 18,2 & 18,2 & 90,9 \\
\hline & concordo totalmente & 1 & 9,1 & 9,1 & 100,0 \\
\hline & Total & 11 & 100,0 & 100,0 & \\
\hline
\end{tabular}


interdependência 5

\begin{tabular}{|c|c|c|c|c|c|}
\hline & & Frequency & Percent & Valid Percent & $\begin{array}{c}\text { Cumulative } \\
\text { Percent }\end{array}$ \\
\hline \multirow[t]{4}{*}{ Valid } & discordo & 1 & 9,1 & 9,1 & $\overline{9,1}$ \\
\hline & $\begin{array}{l}\text { não discordo } \\
\text { nem concordo }\end{array}$ & 2 & 18,2 & 18,2 & 27,3 \\
\hline & concordo & 8 & 72,7 & 72,7 & 100,0 \\
\hline & Total & 11 & 100,0 & 100,0 & \\
\hline
\end{tabular}

interdependêcnia unificada

\begin{tabular}{|ll|r|r|r|r|}
\hline & & & & & Cumulative \\
& & Frequency & Percent & Valid Percent & Percent \\
\hline Valid & 1 & 1 & 9,1 & 9,1 & 9,1 \\
& 5 & 10 & 90,9 & 90,9 & 100,0 \\
& Total & 11 & 100,0 & 100,0 & \\
\hline
\end{tabular}

cooperação 1

\begin{tabular}{|c|c|c|c|c|c|}
\hline & & Frequency & Percent & Valid Percent & $\begin{array}{c}\text { Cumulative } \\
\text { Percent }\end{array}$ \\
\hline \multirow[t]{4}{*}{ Valid } & $\begin{array}{l}\text { não discordo nem } \\
\text { concordo }\end{array}$ & 4 & 36,4 & 36,4 & 36,4 \\
\hline & concordo & 5 & 45,5 & 45,5 & 81,8 \\
\hline & concordo totalmente & 2 & 18,2 & 18,2 & 100,0 \\
\hline & Total & 11 & 100,0 & 100,0 & \\
\hline
\end{tabular}

cooperação 2

\begin{tabular}{|c|c|c|c|c|c|}
\hline & & Frequency & Percent & Valid Percent & $\begin{array}{c}\text { Cumulative } \\
\text { Percent }\end{array}$ \\
\hline \multirow[t]{5}{*}{ Valid } & discordo & 2 & 18,2 & 18,2 & 18,2 \\
\hline & $\begin{array}{l}\text { não discordo nem } \\
\text { concordo }\end{array}$ & 3 & 27,3 & 27,3 & 45,5 \\
\hline & concordo & 5 & 45,5 & 45,5 & 90,9 \\
\hline & concordo totalmente & 1 & 9,1 & 9,1 & 100,0 \\
\hline & Total & 11 & 100,0 & 100,0 & \\
\hline
\end{tabular}


cooperação 3

\begin{tabular}{|ll|r|r|r|r|}
\hline & Frequency & Percent & Valid Percent & \multicolumn{1}{c|}{$\begin{array}{c}\text { Cumulative } \\
\text { Percent }\end{array}$} \\
\hline Valid & discordo & 1 & 9,1 & 9,1 & 9,1 \\
& não discordo nem & 3 & 27,3 & 27,3 & 36,4 \\
concordo & 4 & 36,4 & 36,4 & 72,7 \\
concordo & 3 & 27,3 & 27,3 & 100,0 \\
concordo totalmente & 11 & 100,0 & 100,0 & \\
Total & &
\end{tabular}

cooperação 4

\begin{tabular}{|c|c|c|c|c|c|}
\hline & & Frequency & Percent & Valid Percent & $\begin{array}{l}\text { Cumulative } \\
\text { Percent }\end{array}$ \\
\hline \multirow[t]{5}{*}{ Valid } & discordo & 1 & 9,1 & 9,1 & 9,1 \\
\hline & $\begin{array}{l}\text { não discordo nem } \\
\text { concordo }\end{array}$ & 2 & 18,2 & 18,2 & 27,3 \\
\hline & concordo & 7 & 63,6 & 63,6 & 90,9 \\
\hline & concordo totalmente & 1 & 9,1 & 9,1 & 100,0 \\
\hline & Total & 11 & 100,0 & 100,0 & \\
\hline
\end{tabular}

cooperação 5

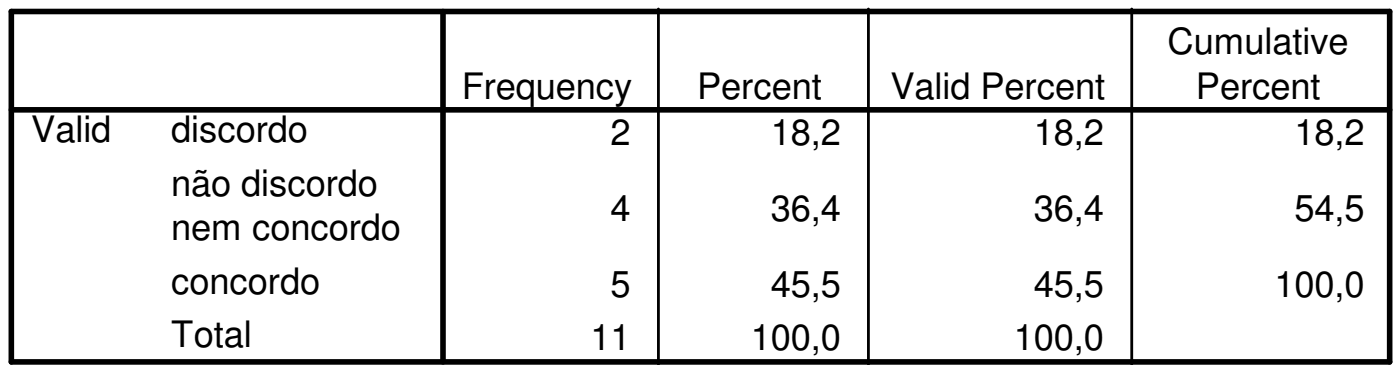

cooperação unificada

\begin{tabular}{|c|c|c|c|c|c|}
\hline & & Frequency & Percent & Valid Percent & $\begin{array}{c}\text { Cumulative } \\
\text { Percent }\end{array}$ \\
\hline \multirow[t]{3}{*}{ Valid } & 1 & 1 & 9,1 & 10,0 & 10,0 \\
\hline & 5 & 9 & 81,8 & 90,0 & 100,0 \\
\hline & Total & 10 & 90,9 & 100,0 & \\
\hline Missing & System & 1 & 9,1 & & \\
\hline Total & & 11 & 100,0 & & \\
\hline
\end{tabular}


COMPORTAMENTO NA COMUNICAĊ̃̃O

compartilhamento 1

\begin{tabular}{|c|c|c|c|c|c|}
\hline & & Frequency & Percent & Valid Percent & $\begin{array}{l}\text { Cumulative } \\
\text { Percent }\end{array}$ \\
\hline \multirow[t]{5}{*}{ Valid } & discordo & 2 & $\overline{18,2}$ & 18,2 & $\overline{18,2}$ \\
\hline & $\begin{array}{l}\text { não discordo nem } \\
\text { concordo }\end{array}$ & 1 & 9,1 & 9,1 & 27,3 \\
\hline & concordo & 5 & 45,5 & 45,5 & 72,7 \\
\hline & concordo totalmente & 3 & 27,3 & 27,3 & 100,0 \\
\hline & Total & 11 & 100,0 & 100,0 & \\
\hline
\end{tabular}

compartilhamento 2

\begin{tabular}{|c|c|c|c|c|c|}
\hline & & Frequency & Percent & Valid Percent & $\begin{array}{l}\text { Cumulative } \\
\text { Percent }\end{array}$ \\
\hline \multirow[t]{5}{*}{ Valid } & discordo & 3 & 27,3 & 27,3 & 27,3 \\
\hline & $\begin{array}{l}\text { não discordo nem } \\
\text { concordo }\end{array}$ & 4 & 36,4 & 36,4 & 63,6 \\
\hline & concordo & 3 & 27,3 & 27,3 & 90,9 \\
\hline & concordo totalmente & 1 & 9,1 & 9,1 & 100,0 \\
\hline & Total & 11 & 100,0 & 100,0 & \\
\hline
\end{tabular}

\section{compartilhamento 3}

\begin{tabular}{|ll|r|r|r|r|}
\hline & & & & \multicolumn{1}{c|}{$\begin{array}{c}\text { Cumulative } \\
\text { Percent }\end{array}$} \\
\hline Valid & não discordo & 4 & 36,4 & 36,4 & 36,4 \\
& nem concordo & 7 & 63,6 & 63,6 & 100,0 \\
concordo & 11 & 100,0 & 100,0 & \\
Total & & Percent & Valid Percent \\
\hline
\end{tabular}

compartilhamento 4

\begin{tabular}{|c|c|c|c|c|c|}
\hline & & Frequency & Percent & Valid Percent & $\begin{array}{c}\text { Cumulative } \\
\text { Percent }\end{array}$ \\
\hline \multirow[t]{3}{*}{ Valid } & concordo & 6 & 54,5 & 54,5 & 54,5 \\
\hline & concordo totalmente & 5 & 45,5 & 45,5 & 100,0 \\
\hline & Total & 11 & 100,0 & 100,0 & \\
\hline
\end{tabular}


compartilhamento 5

\begin{tabular}{|c|c|c|c|c|c|}
\hline & & Frequency & Percent & Valid Percent & $\begin{array}{l}\text { Cumulative } \\
\text { Percent }\end{array}$ \\
\hline \multirow[t]{5}{*}{ Valid } & discordo & 1 & 9,1 & 9,1 & 9,1 \\
\hline & $\begin{array}{l}\text { não discordo nem } \\
\text { concordo }\end{array}$ & 1 & 9,1 & 9,1 & 18,2 \\
\hline & concordo & 6 & 54,5 & 54,5 & 72,7 \\
\hline & concordo totalmente & 3 & 27,3 & 27,3 & 100,0 \\
\hline & Total & 11 & 100,0 & 100,0 & \\
\hline
\end{tabular}

compartilhamento unificado

\begin{tabular}{|c|c|c|c|c|c|}
\hline & & Frequency & Percent & Valid Percent & $\begin{array}{l}\text { Cumulative } \\
\text { Percent }\end{array}$ \\
\hline$\overline{\text { Valid }}$ & 5 & 10 & 90,9 & 100,0 & 100,0 \\
\hline Missing & System & 1 & 9,1 & & \\
\hline Total & & 11 & 100,0 & & \\
\hline
\end{tabular}

participação 1

\begin{tabular}{|c|c|c|c|c|c|}
\hline & & Frequency & Percent & Valid Percent & $\begin{array}{c}\text { Cumulative } \\
\text { Percent }\end{array}$ \\
\hline \multirow[t]{4}{*}{ Valid } & discordo & 4 & 36,4 & 36,4 & 36,4 \\
\hline & $\begin{array}{l}\text { não discordo } \\
\text { nem concordo }\end{array}$ & 2 & 18,2 & 18,2 & 54,5 \\
\hline & concordo & 5 & 45,5 & 45,5 & 100,0 \\
\hline & Total & 11 & 100,0 & 100,0 & \\
\hline
\end{tabular}

participação 2

\begin{tabular}{|c|c|c|c|c|c|}
\hline & & Frequency & Percent & Valid Percent & $\begin{array}{c}\text { Cumulative } \\
\text { Percent }\end{array}$ \\
\hline \multirow[t]{5}{*}{ Valid } & discordo & 5 & 45,5 & 45,5 & 45,5 \\
\hline & $\begin{array}{l}\text { não discordo nem } \\
\text { concordo }\end{array}$ & 4 & 36,4 & 36,4 & 81,8 \\
\hline & concordo & 1 & 9,1 & 9,1 & 90,9 \\
\hline & concordo totalmente & 1 & 9,1 & 9,1 & 100,0 \\
\hline & Total & 11 & 100,0 & 100,0 & \\
\hline
\end{tabular}


participação 3

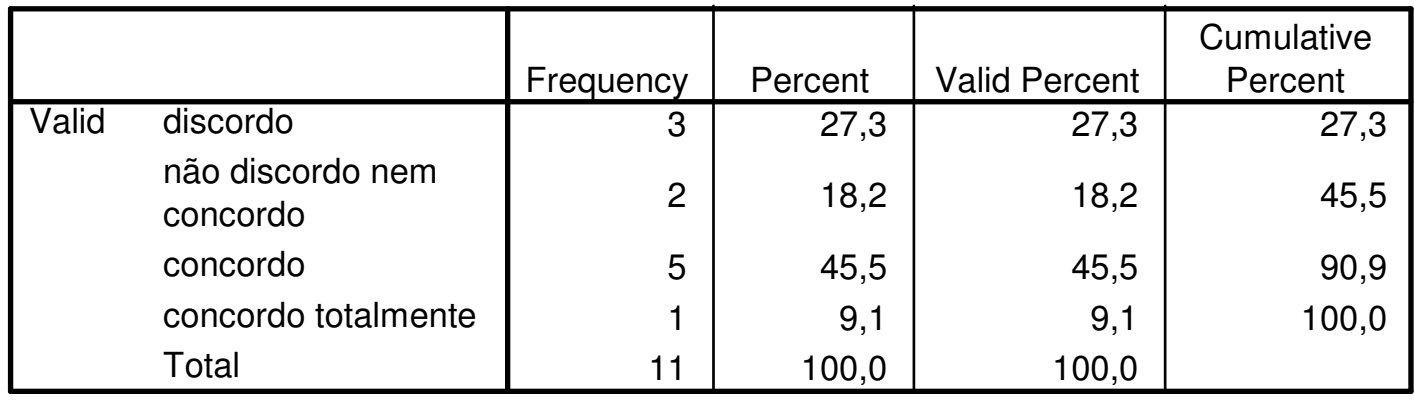

participação 4

\begin{tabular}{|c|c|c|c|c|c|}
\hline & & Frequency & Percent & Valid Percent & $\begin{array}{c}\text { Cumulative } \\
\text { Percent }\end{array}$ \\
\hline \multirow[t]{4}{*}{ Valid } & discordo & 7 & 63,6 & 63,6 & 63,6 \\
\hline & $\begin{array}{l}\text { não discordo } \\
\text { nem concordo }\end{array}$ & 3 & 27,3 & 27,3 & 90,9 \\
\hline & concordo & 1 & 9,1 & 9,1 & 100,0 \\
\hline & Total & 11 & 100,0 & 100,0 & \\
\hline
\end{tabular}

participação 5

\begin{tabular}{|c|c|c|c|c|c|}
\hline & Frequency & Percent & Valid Percent & $\begin{array}{c}\text { Cumulative } \\
\text { Percent }\end{array}$ \\
\hline \multirow[t]{4}{*}{\begin{tabular}{|l|} 
Valid \\
\end{tabular}} & discordo & 4 & $\overline{36,4}$ & 36,4 & 36,4 \\
\hline & $\begin{array}{l}\text { não discordo } \\
\text { nem concordo }\end{array}$ & 5 & 45,5 & 45,5 & 81,8 \\
\hline & concordo & 2 & 18,2 & 18,2 & 100,0 \\
\hline & Total & 11 & 100,0 & 100,0 & \\
\hline
\end{tabular}

participação unificada

\begin{tabular}{|ll|r|r|r|r|}
\hline & & & & & Cumulative \\
& & Frequency & Percent & Valid Percent & Percent \\
\hline Valid & 1 & 5 & 45,5 & 62,5 & 62,5 \\
& 5 & 3 & 27,3 & 37,5 & 100,0 \\
& Total & 8 & 72,7 & 100,0 & \\
Missing & System & 3 & 27,3 & & \\
Total & 11 & 100,0 & & \\
\hline
\end{tabular}




\section{TÉCNICAS DE RESOLUCC̃̃O DE CONFLITOS}

conflito/dominação

\begin{tabular}{|ll|r|r|r|r|}
\hline & & & & Cumulative \\
& Frequency & Percent & Valid Percent & Percent \\
\hline Valid & raramente & 2 & 18,2 & 18,2 & 18,2 \\
& 4 & 36,4 & 36,4 & 54,5 \\
& às vezes & 5 & 45,5 & 45,5 & 100,0 \\
& frequentemente & 11 & 100,0 & 100,0 & \\
Total &
\end{tabular}

conflito/colaboração

\begin{tabular}{|c|c|c|c|c|c|}
\hline & & Frequency & Percent & Valid Percent & $\begin{array}{c}\text { Cumulative } \\
\text { Percent }\end{array}$ \\
\hline \multirow[t]{5}{*}{$\overline{\text { Valid }}$} & raramente & 1 & $\overline{9,1}$ & 9,1 & 9,1 \\
\hline & às vezes & 7 & 63,6 & 63,6 & 72,7 \\
\hline & frequentemente & 2 & 18,2 & 18,2 & 90,9 \\
\hline & sempre & 1 & 9,1 & 9,1 & 100,0 \\
\hline & Total & 11 & 100,0 & 100,0 & \\
\hline
\end{tabular}

conflito/subestimação

\begin{tabular}{|ll|r|r|r|r|}
\hline & & & & \multicolumn{1}{c|}{$\begin{array}{c}\text { Cumulative } \\
\text { Percent }\end{array}$} \\
\hline Valid & nunca & 1 & 9,1 & 9,1 & 9,1 \\
& raramente & 5 & 45,5 & 45,5 & 54,5 \\
& às vezes & 3 & 27,3 & 27,3 & 81,8 \\
& frequentemente & 2 & 18,2 & 18,2 & 100,0 \\
& Total & 11 & 100,0 & 100,0 & \\
\hline
\end{tabular}

conflito/acomodação

\begin{tabular}{|c|c|c|c|c|c|}
\hline & & Frequency & Percent & Valid Percent & $\begin{array}{c}\text { Cumulative } \\
\text { Percent }\end{array}$ \\
\hline \multirow[t]{4}{*}{ Valid } & raramente & 4 & 36,4 & 36,4 & 36,4 \\
\hline & às vezes & 6 & 54,5 & 54,5 & 90,9 \\
\hline & frequentemente & 1 & 9,1 & 9,1 & 100,0 \\
\hline & Total & 11 & 100,0 & 100,0 & \\
\hline
\end{tabular}


conflito/compromisso

\begin{tabular}{|c|c|c|c|c|c|}
\hline & & Frequency & Percent & Valid Percent & $\begin{array}{c}\text { Cumulative } \\
\text { Percent }\end{array}$ \\
\hline \multirow[t]{4}{*}{ Valid } & raramente & 1 & 9,1 & 9,1 & $\overline{9,1}$ \\
\hline & às vezes & 5 & 45,5 & 45,5 & 54,5 \\
\hline & frequentemente & 5 & 45,5 & 45,5 & 100,0 \\
\hline & Total & 11 & 100,0 & 100,0 & \\
\hline
\end{tabular}

SUCESSO DA PARCERIA

satisfação 1

\begin{tabular}{|c|c|c|c|c|c|}
\hline & & Frequency & Percent & Valid Percent & $\begin{array}{c}\text { Cumulative } \\
\text { Percent }\end{array}$ \\
\hline \multirow[t]{4}{*}{ Valid } & discordo & 5 & 45,5 & 45,5 & 45,5 \\
\hline & $\begin{array}{l}\text { não discordo } \\
\text { nem concordo }\end{array}$ & 2 & 18,2 & 18,2 & 63,6 \\
\hline & concordo & 4 & 36,4 & 36,4 & 100,0 \\
\hline & Total & 11 & 100,0 & 100,0 & \\
\hline
\end{tabular}

satisfação 2

\begin{tabular}{|c|c|c|c|c|c|}
\hline & & Frequency & Percent & Valid Percent & $\begin{array}{l}\text { Cumulative } \\
\text { Percent }\end{array}$ \\
\hline \multirow[t]{5}{*}{ Valid } & discordo totalmente & 1 & 9,1 & 9,1 & 9,1 \\
\hline & discordo & 5 & 45,5 & 45,5 & 54,5 \\
\hline & $\begin{array}{l}\text { não discordo nem } \\
\text { concordo }\end{array}$ & 2 & 18,2 & 18,2 & 72,7 \\
\hline & concordo & 3 & 27,3 & 27,3 & 100,0 \\
\hline & Total & 11 & 100,0 & 100,0 & \\
\hline
\end{tabular}

satisfação 3

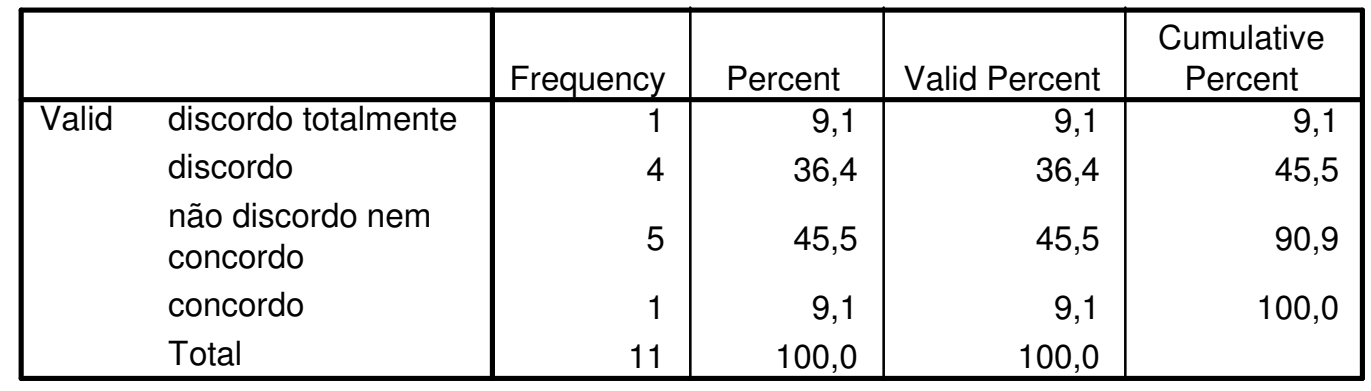


satisfação 4

\begin{tabular}{|c|c|c|c|c|c|}
\hline & Frequency & Percent & Valid Percent & $\begin{array}{c}\text { Cumulative } \\
\text { Percent }\end{array}$ \\
\hline \multirow[t]{4}{*}{ Valid } & discordo & 2 & 18,2 & 18,2 & 18,2 \\
\hline & $\begin{array}{l}\text { não discordo } \\
\text { nem concordo }\end{array}$ & 4 & 36,4 & 36,4 & 54,5 \\
\hline & concordo & 5 & 45,5 & 45,5 & 100,0 \\
\hline & Total & 11 & 100,0 & 100,0 & \\
\hline
\end{tabular}

satisfação 5

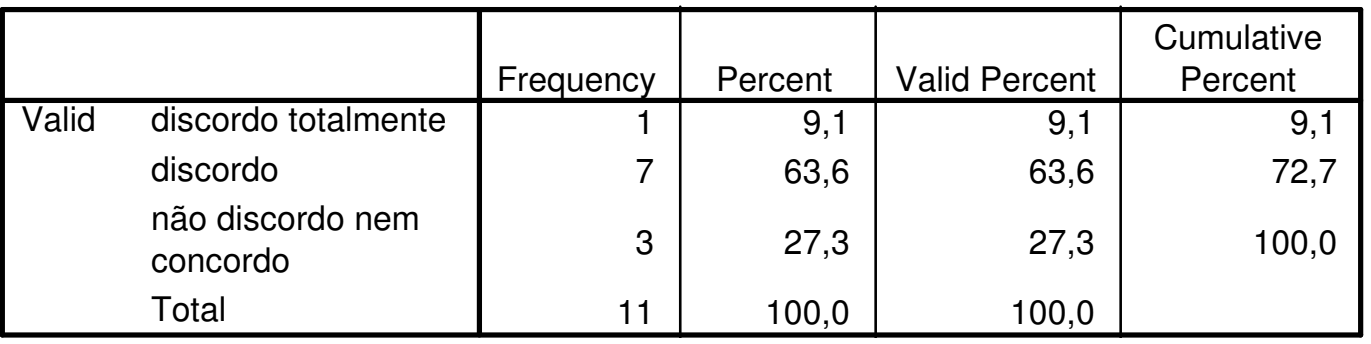

satisfação unificada

\begin{tabular}{|rl|r|r|r|r|}
\hline & & & & & Cumulative \\
& & Frequency & Percent & Valid Percent & Percent \\
\hline Valid & 1 & 7 & 63,6 & 63,6 & 63,6 \\
& 5 & 4 & 36,4 & 36,4 & 100,0 \\
& Total & 11 & 100,0 & 100,0 & \\
\hline
\end{tabular}


APÊNDICE 5

TABELAS DE CONTINGÊNCIA PARA A SATISFAÇÃO GERAL

ATRIBUTOS DA PARCERIA

confiança unificada * satisfação unificada Crosstabulation

\begin{tabular}{|c|c|c|c|c|c|}
\hline & \multicolumn{2}{|c|}{ satisfação unificada } & \multirow[b]{2}{*}{ Total } \\
\hline & & & 1 & 5 & \\
\hline \multirow{4}{*}{$\begin{array}{l}\text { confiança } \\
\text { unificada }\end{array}$} & 1 & Count & $\overline{2}$ & & 2 \\
\hline & & $\%$ of Total & $20,0 \%$ & & $20,0 \%$ \\
\hline & 5 & Count & 4 & 4 & 8 \\
\hline & & $\%$ of Total & $40,0 \%$ & $40,0 \%$ & $80,0 \%$ \\
\hline \multirow[t]{2}{*}{ Total } & & Count & 6 & 4 & 10 \\
\hline & & $\%$ of Total & $60,0 \%$ & $40,0 \%$ & $100,0 \%$ \\
\hline
\end{tabular}

comprometimento unificado * satisfação unificada Crosstabulation

\begin{tabular}{|c|c|c|c|c|c|}
\hline & \multicolumn{2}{|c|}{ satisfação unificada } & \multirow[b]{2}{*}{ Total } \\
\hline & & & 1 & 5 & \\
\hline \multirow{4}{*}{$\begin{array}{l}\text { comprometimento } \\
\text { unificado }\end{array}$} & 1 & Count & 3 & & $\overline{3}$ \\
\hline & & $\%$ of Total & $30,0 \%$ & & $30,0 \%$ \\
\hline & 5 & Count & 3 & 4 & 7 \\
\hline & & $\%$ of Total & $30,0 \%$ & $40,0 \%$ & $70,0 \%$ \\
\hline \multirow[t]{2}{*}{ Total } & & Count & 6 & 4 & 10 \\
\hline & & $\%$ of Total & $60,0 \%$ & $40,0 \%$ & $100,0 \%$ \\
\hline
\end{tabular}

interdependência unificada * satisfação unificada Crosstabulation

\begin{tabular}{|lll|r|r|r|}
\hline & & \multicolumn{2}{|c|}{ satisfação unificada } & \multirow{2}{*}{ Total } \\
\cline { 3 - 5 } & & 1 & 5 & 1 \\
\hline interdependência & 1 & Count & 1 & & $9,1 \%$ \\
\hline unificada & & \% of Total & $9,1 \%$ & & 10 \\
& 5 & $\begin{array}{l}\text { Count } \\
\text { \% of Total }\end{array}$ & $64,5 \%$ & $36,4 \%$ & $90,9 \%$ \\
\hline Total & & $\begin{array}{l}\text { Count } \\
\text { \% of Total }\end{array}$ & $63,6 \%$ & 4 & 11 \\
& & \multicolumn{3}{c}{$36,4 \%$} & $100,0 \%$ \\
\hline
\end{tabular}


cooperação unificada * satisfação unificada Crosstabulation

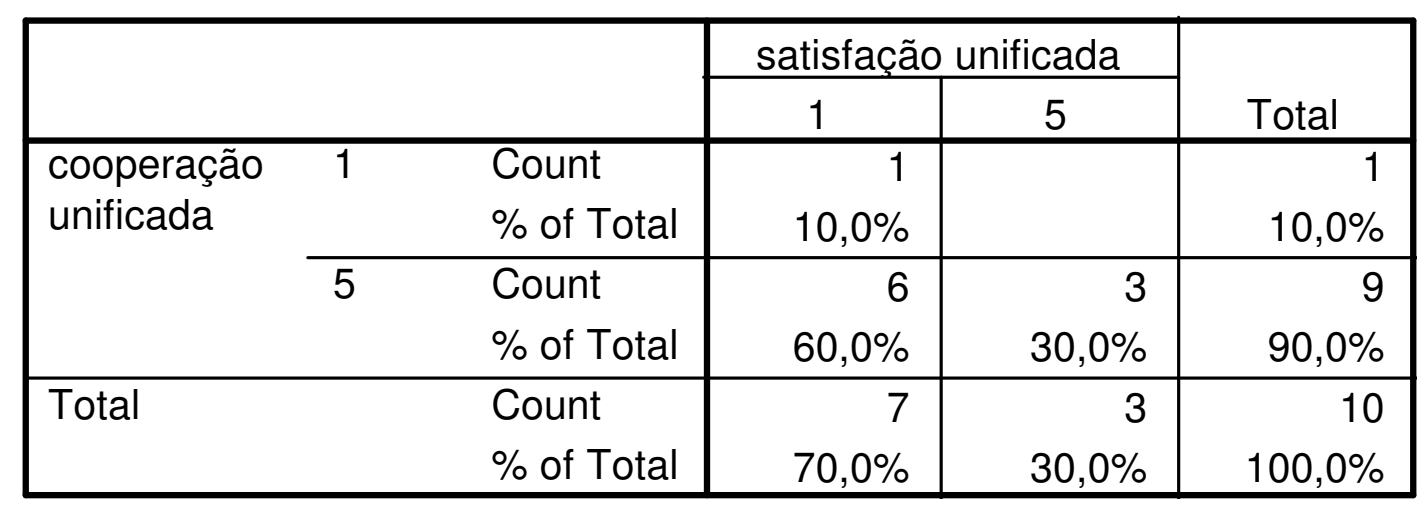

\section{COMPORTAMENTO NA COMUNICACẼ̃O}

compartilhamento unificado * satisfação unificada Crosstabulation

\begin{tabular}{|c|c|c|c|c|}
\hline & \multicolumn{2}{|c|}{ satisfação unificada } & \multirow[b]{2}{*}{ Total } \\
\hline & & 1 & 5 & \\
\hline \multirow{2}{*}{$\begin{array}{l}\text { compartilhamento } \\
\text { unificado }\end{array}$} & Count & 6 & 4 & 10 \\
\hline & $\%$ of Total & $60,0 \%$ & $40,0 \%$ & $100,0 \%$ \\
\hline \multirow[t]{2}{*}{ Total } & Count & 6 & 4 & 10 \\
\hline & $\%$ of Total & $60,0 \%$ & $40,0 \%$ & $100,0 \%$ \\
\hline
\end{tabular}

participação unificada * satisfação unificada Crosstabulation

\begin{tabular}{|c|c|c|c|c|c|}
\hline & \multicolumn{2}{|c|}{ satisfação unificada } & \multirow[b]{2}{*}{ Total } \\
\hline & & & 1 & 5 & \\
\hline \multirow{4}{*}{$\begin{array}{l}\text { participação } \\
\text { unificada }\end{array}$} & 1 & Count & $\overline{5}$ & & $\overline{5}$ \\
\hline & & $\%$ of Total & $62,5 \%$ & & $62,5 \%$ \\
\hline & 5 & Count & 1 & 2 & 3 \\
\hline & & $\%$ of Total & $12,5 \%$ & $25,0 \%$ & $37,5 \%$ \\
\hline \multirow[t]{2}{*}{ Total } & & Count & 6 & 2 & 8 \\
\hline & & $\%$ of Total & $75,0 \%$ & $25,0 \%$ & $100,0 \%$ \\
\hline
\end{tabular}


TÉCNICAS DE RESOLUCÃO DE CONFLITOS

conflito/dominação * satisfação unificada Crosstabulation

\begin{tabular}{|lll|r|r|r|}
\hline & & & \multicolumn{2}{|c|}{ satisfação unificada } & \multirow{2}{*}{ Total } \\
\cline { 3 - 5 } & & 1 & 5 & \multicolumn{1}{c|}{2} \\
\hline conflito/dominação & 1 & Count & 1 & 1 & $28,6 \%$ \\
& & \% of Total & $14,3 \%$ & $14,3 \%$ & 5 \\
& & Count & 4 & 1 & $71,4 \%$ \\
\cline { 3 - 5 } & 5 & \% of Total & $57,1 \%$ & $14,3 \%$ & 7 \\
\hline Total & & Count & 5 & 2 & $100,0 \%$ \\
\hline
\end{tabular}

conflito/colaboração * satisfação unificada Crosstabulation

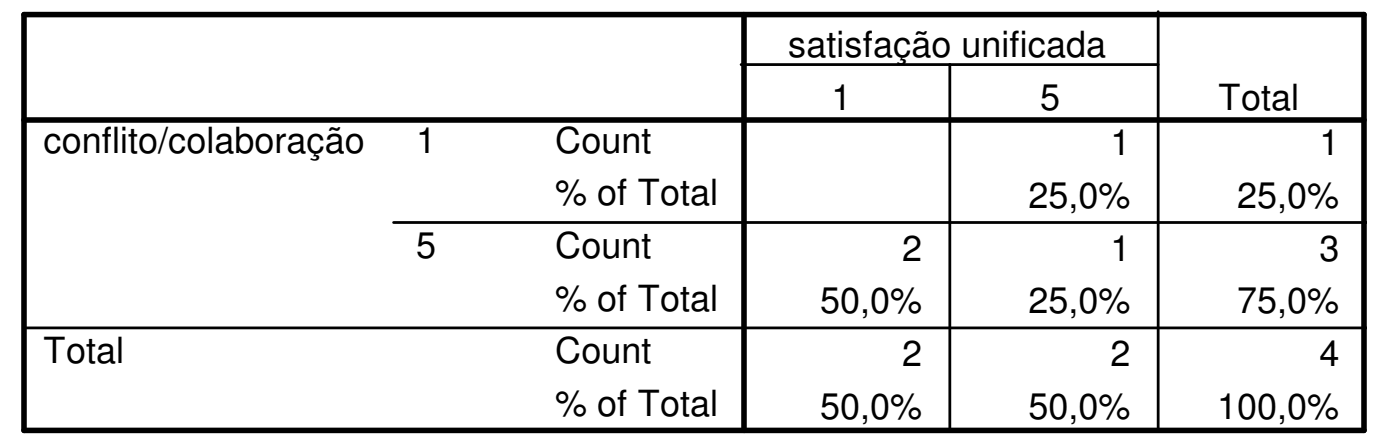

conflito/subestimação * satisfação unificada Crosstabulation

\begin{tabular}{|lll|r|r|r|}
\hline & & & \multicolumn{2}{|c|}{ satisfação unificada } & \multirow{2}{*}{ Total } \\
\cline { 4 - 6 } & & 1 & \multicolumn{1}{c|}{5} & 6 \\
\hline conflito/subestimação & 1 & Count & 5 & 1 & $75,0 \%$ \\
& & \% of Total & $62,5 \%$ & $12,5 \%$ & 2 \\
& 5 & Count & 1 & 1 & $25,0 \%$ \\
\hline Total & \% of Total & $12,5 \%$ & $12,5 \%$ & 8 \\
& & Count & 6 & 2 & $100,0 \%$ \\
\hline
\end{tabular}


conflito/acomodação * satisfação unificada Crosstabulation

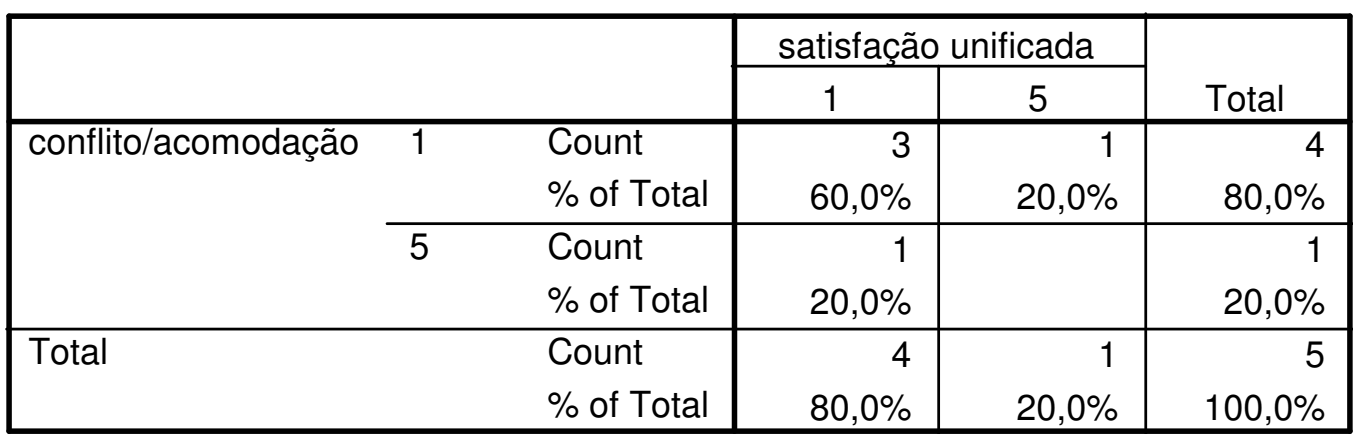

conflito/compromisso * satisfação unificada Crosstabulation

\begin{tabular}{|lll|r|r|r|}
\hline & & & \multicolumn{2}{|c|}{ satisfação unificada } & \multirow{2}{*}{ Total } \\
\cline { 3 - 5 } & & 1 & \multicolumn{1}{c|}{5} & \multicolumn{1}{c|}{1} \\
\hline conflito/compromisso & 1 & Count & 1 & & $16,7 \%$ \\
\cline { 3 - 5 } & & \% of Total & $16,7 \%$ & & 5 \\
& 5 & Count & 3 & 2 & $83,3 \%$ \\
\hline Total & \% of Total & $50,0 \%$ & $33,3 \%$ & 6 \\
& & Count & 4 & 2 & $100,0 \%$ \\
\hline
\end{tabular}




\section{APÊNDICE 6}

TABELAS DE CONTINGÊNCIA ENTRE CARACTERÍSTICAS

confiança unificada * comprometimento unificado Crosstabulation

\begin{tabular}{|c|c|c|c|c|c|}
\hline & \multicolumn{2}{|c|}{$\begin{array}{l}\text { comprometimento } \\
\text { unificado }\end{array}$} & \multirow[b]{2}{*}{ Total } \\
\hline & & & 1 & 5 & \\
\hline \multirow{4}{*}{$\begin{array}{l}\text { Confiança } \\
\text { unificada }\end{array}$} & 1 & Count & 2 & & $\overline{2}$ \\
\hline & & $\%$ of Total & $22,2 \%$ & & $22,2 \%$ \\
\hline & 5 & Count & 1 & 6 & 7 \\
\hline & & $\%$ of Total & $11,1 \%$ & $66,7 \%$ & $77,8 \%$ \\
\hline \multirow[t]{2}{*}{ Total } & & Count & 3 & 6 & 9 \\
\hline & & $\%$ of Total & $33,3 \%$ & $66,7 \%$ & $100,0 \%$ \\
\hline
\end{tabular}

confiança unificada * cooperação unificada Crosstabulation

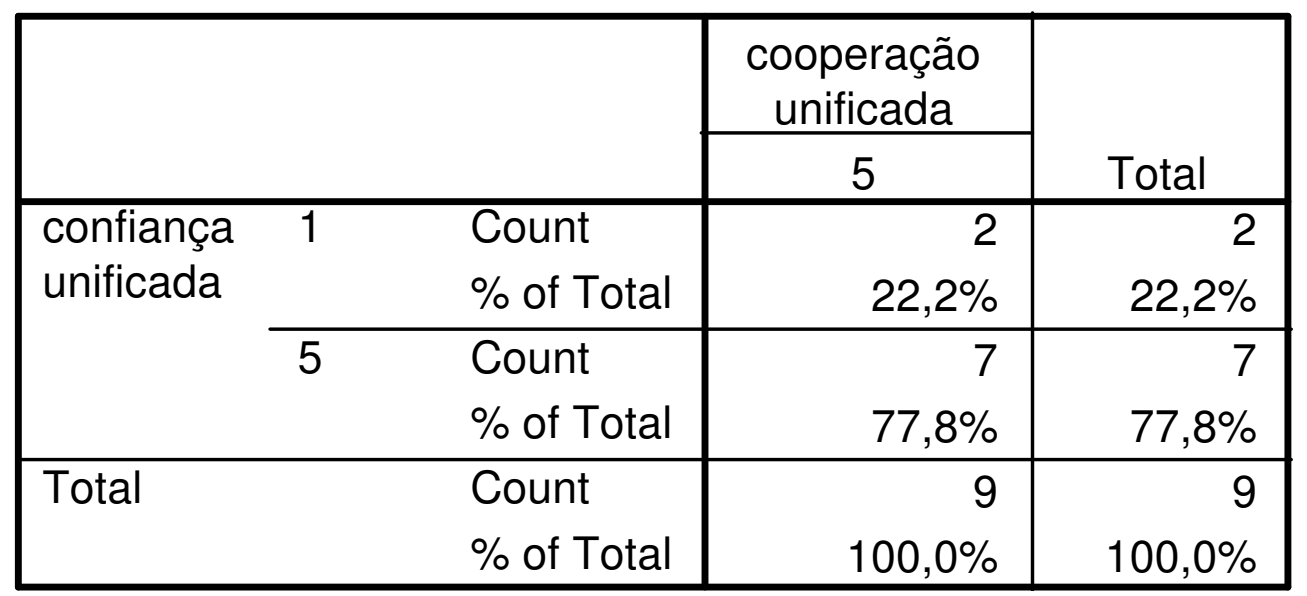


comprometimento unificado * cooperação unificada Crosstabulation

\begin{tabular}{|lll|r|r|r|}
\hline & & & \multicolumn{2}{|c|}{ cooperação unificada } & \multirow{2}{*}{ Total } \\
\cline { 4 - 5 } & & 1 & 5 & 3 \\
\hline $\begin{array}{l}\text { comprometimento } \\
\text { unificado }\end{array}$ & 1 & Count & & 3 & $33,3 \%$ \\
& & \% of Total & & $33,3 \%$ & 3 \\
\cline { 2 - 5 } & 5 & Count & 1 & 5 & $66,7 \%$ \\
\hline Total & & \% of Total & $11,1 \%$ & $55,6 \%$ & 9 \\
& & Count & 1 & 8 & $100,0 \%$ \\
\hline
\end{tabular}

confiança unificada * interdependência unificada Crosstabulation

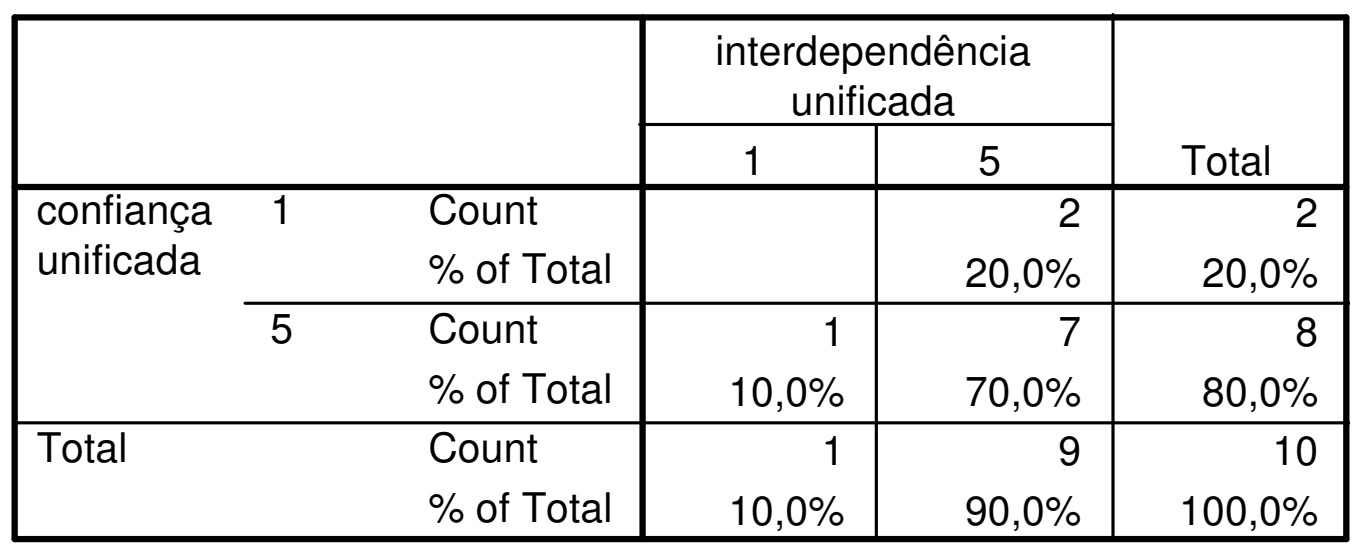

comprometimento unificado * interdependência unificada Crosstabulation

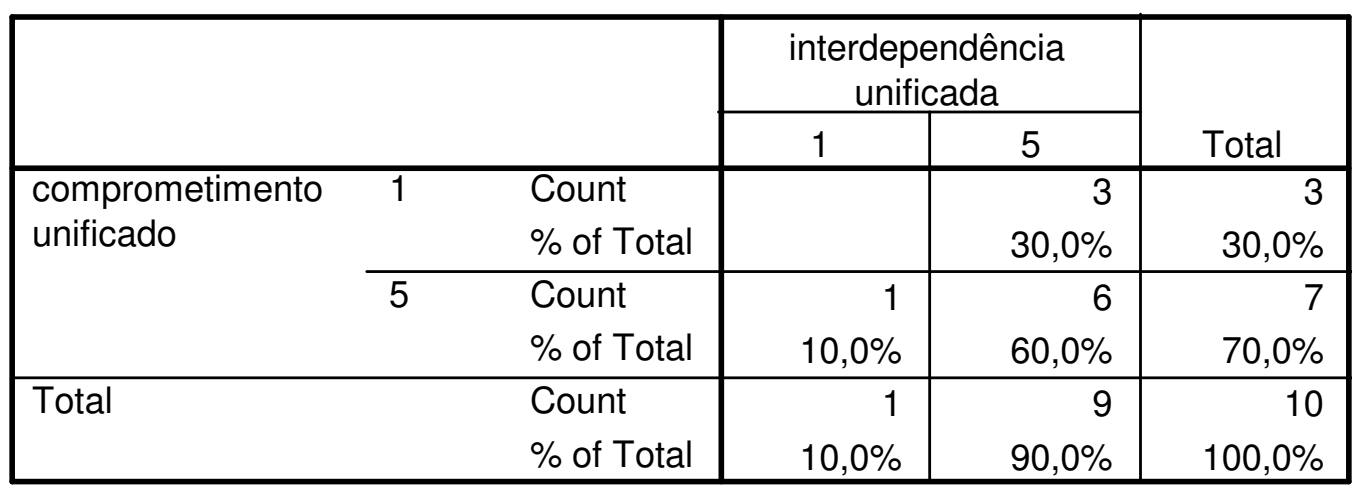


ANEXOS

ANEXO 1: CONSOLIDAÇÃO DA INDÚSTRIA AEROESPACIAL NOS EUA ANEXO 2: CONSOLIDAÇÃO DA INDÚSTRIA AEROESPACIAL NA EUROPA ANEXO 3: ACORDOS DE COOPERAÇÃO NA INDÚSTRIA AERONÁUTICA ANEXO 4: DIAGRAMA ESQUEMÁTICO DO PROCESSO DE MANUFATURA ANEXO 5: DOMÍNIO DO CICLO DE VIDA DO NEGÓCIO AERONÁUTICO 
ANEXO 1

CONSOLIDAÇÃO DA INDÚSTRIA AEROESPACIAL NOS EUA
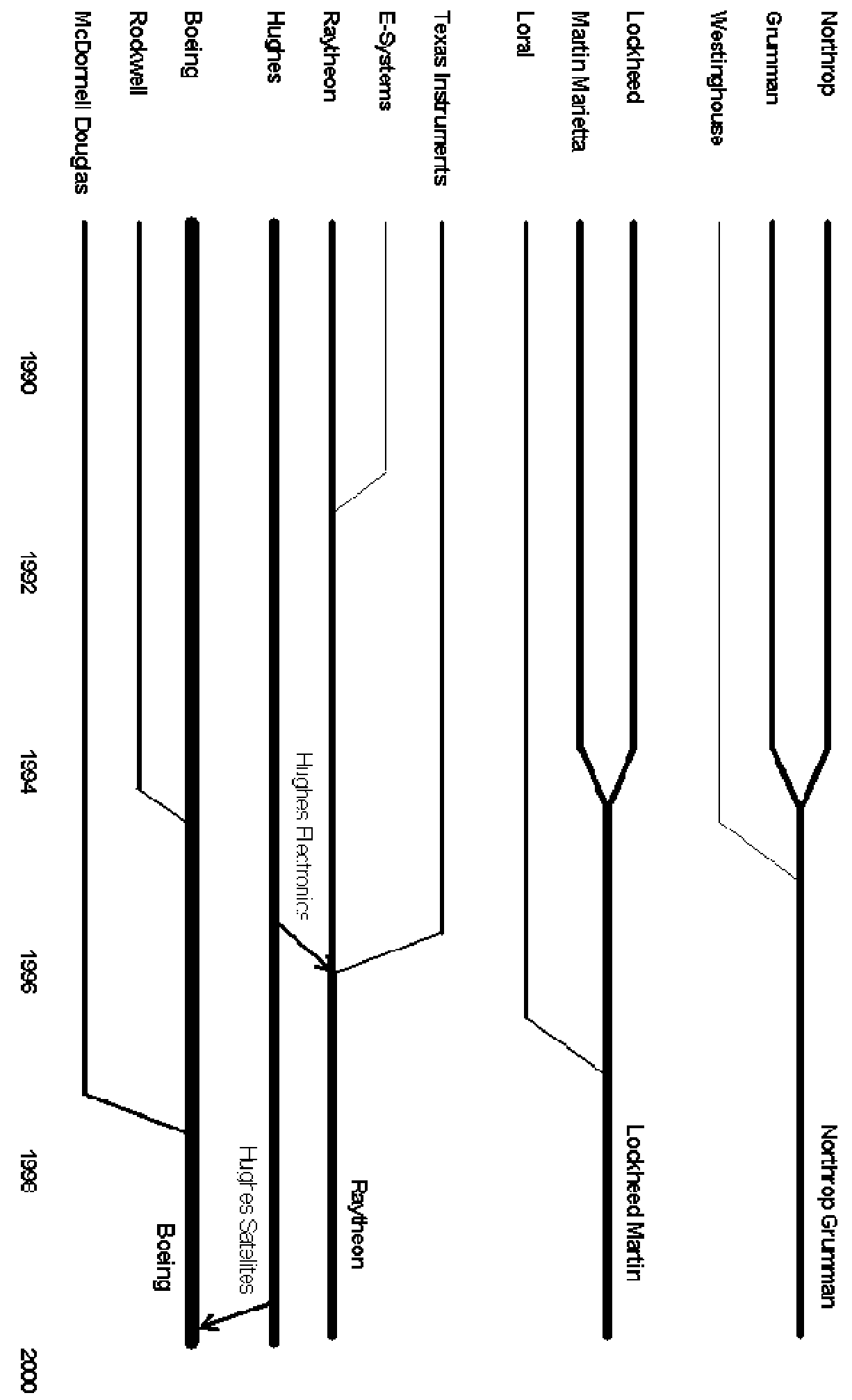

Fonte: SCHMITT, 2002. 


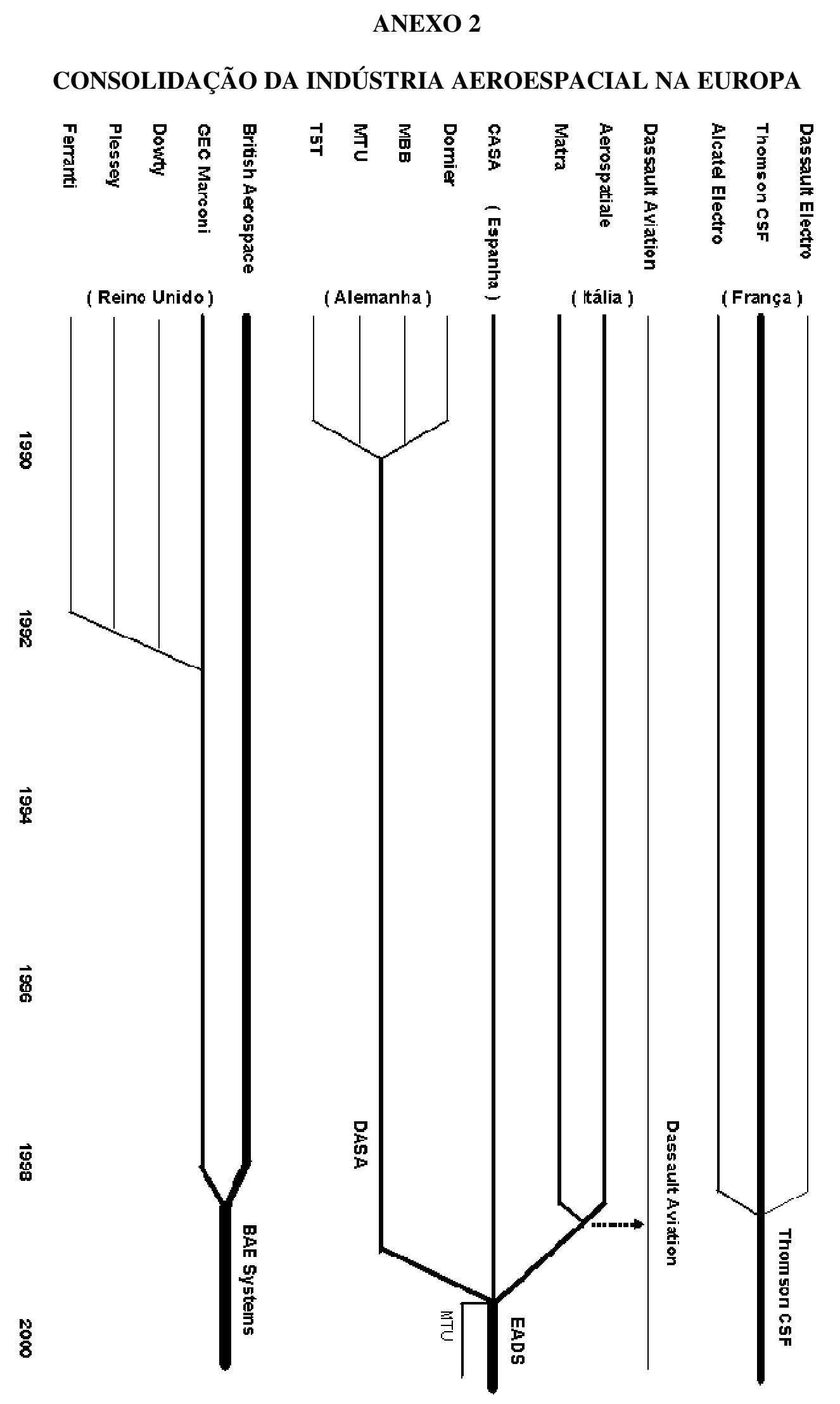

Fonte: SCHMITT, 2002. 
ANEXO 3

ACORDOS DE COOPERAÇÃO NA INDÚSTRIA AERONÁUTICA

\begin{tabular}{|c|c|c|c|}
\hline Período & Projeto & Empresas participantes & $\begin{array}{l}\text { Total de } \\
\text { acordos }\end{array}$ \\
\hline Anos 50 & & & 0 \\
\hline Anos 60 & $\begin{array}{l}\text { Concorde } \\
\text { Transall } \\
\text { Sepcat } \\
\text { Adour (m) } \\
\text { Olympus (m) } \\
\text { RR/Allison (m) } \\
\end{array}$ & $\begin{array}{c}\text { Aerospatiale, BAE (50\%) } \\
\text { Aerospatiale, MBB/DASA (50\%) } \\
\text { Dassault, BAE ( } 50 \%) \\
\text { Rolls-Royce, Turbomeca }(50 \%) \\
\text { BSC/Rolls-Royce, Snecma }(50 \%) \\
\text { Rolls-Royce, Allison }(50 \%) \\
\end{array}$ & 6 \\
\hline Anos 70 & $\begin{array}{c}\text { A300 } \\
\text { Alpha-Jet } \\
\text { IAR } \\
\text { Panavia } \\
\text { CMF (m) } \\
\text { Turbo-Union }(\mathrm{m})\end{array}$ & $\begin{array}{c}\text { Aerospatiale (38\%), BAE (20\%), DASA (38\%), CASA (4\%) } \\
\text { Dassaut, Dornier (50\%) } \\
\text { CNIAR, SOKO (50\%) } \\
\text { BAE (42,5\%), DASA }(42,5 \%), \text { Alenia }(15 \%) \\
\text { GE, Snecma }(50 \%) \\
\text { Fiat Avio (20\%), MTU (40\%), Rolls-Royce }(40 \%)\end{array}$ & 12 \\
\hline Anos 80 & $\begin{array}{l}\text { A310 } \\
\text { A320 } \\
\text { ATR42 } \\
\text { ATR72 } \\
\text { Airtech } \\
\text { AMX } \\
\text { Harrier } \\
\text { IAI }(\mathrm{m}) \\
\text { MTR }(\mathrm{m}) \\
\end{array}$ & $\begin{array}{c}\text { Aerospatiale (38\%), BAE (20\%), DASA (38\%), CASA (4\%) } \\
\text { Aerospatiale (38\%), BAE (20\%), DASA (38\%), CASA (4\%) } \\
\text { Aerospatiale, Alenia }(50 \%) \\
\text { Aerospatiale, Alenia (50\%) } \\
\text { CASA, IPTN }(50 \%) \\
\text { Alenia (46,5\%), Aermacchi }(23,8 \%), \text { Embraer }(29,7 \%) \\
\text { McDonnell Douglas }(60 \%), \text { BAE }(40 \%) \\
\text { Fiat Avio, JAEC, Pratt \& Whitney, Rolls-Royce } \\
\text { MTU-DASA, Rolls-Royce, Turbomeca }(33,3 \%)\end{array}$ & 17 \\
\hline Anos 90 & $\begin{array}{c}\text { A330 } \\
\text { A340 } \\
\text { Satic } \\
\text { EFA } \\
\text { F-22 } \\
\text { Eurojet (m) } \\
\text { A380 } \\
\text { Dasa/Tup } \\
\text { A400M } \\
\text { RR/Saturn (m) }\end{array}$ & $\begin{array}{c}\text { Aerospatiale (38\%), BAE (20\%), DASA (38\%), CASA (4\%) } \\
\text { Aerospatiale (38\%), BAE (20\%), DASA }(38 \%) \text {, CASA }(4 \%) \\
\text { Aerospatiale, DASA }(50 \%) \\
\text { BAE (37\%), DASA (30\%), Alenia }(19,5 \%) \text {, CASA }(13,5 \%) \\
\text { Boeing }(33 \%), \text { Lockheed }(67 \%) \\
\text { Fiat Avio (21\%), MTU (33\%), ITP (13\%), Rolls-Royce }(33 \%) \\
\text { Aerospatiale (38\%), BAE (20\%), DASA (38\%), CASA (4\%) } \\
\text { DASA, Tupolev (50\%) } \\
\text { EADS, BAE, TAI, Flabel } \\
\text { Rolls-Royce, Saturn }(50 \%)\end{array}$ & 26 \\
\hline \multicolumn{4}{|c|}{$\begin{array}{l}\text { Alemanha: Dornier; DASA (ex-MBB); MTU (DASA); } \\
\text { Brasil: Embraer; } \\
\text { Espanha: CASA; ITP; } \\
\text { EUA: Allison; Boeing; GE; Lockheed; McDonnell Douglas; Pratt \& Whitney; } \\
\text { França: Aerospatiale; Dassault; Snecma; Turbomeca; } \\
\text { Indonésia: IPTN; } \\
\text { Itália: Aermacchi; Alenia; Fiat Avio; } \\
\text { Iugoslávia: SOKO; } \\
\text { Japão: JAEC; } \\
\text { Reino Unido: BAE; Rolls-Royce; } \\
\text { Romênia: CNIAR; } \\
\text { Rússia: Saturn; Tupolev. }\end{array}$} \\
\hline
\end{tabular}

Fonte: ESPOSITO, 2004. 


\section{ANEXO 4 \\ DIAGRAMA ESQUEMÁTICO DO PROCESSO DE MANUFATURA}

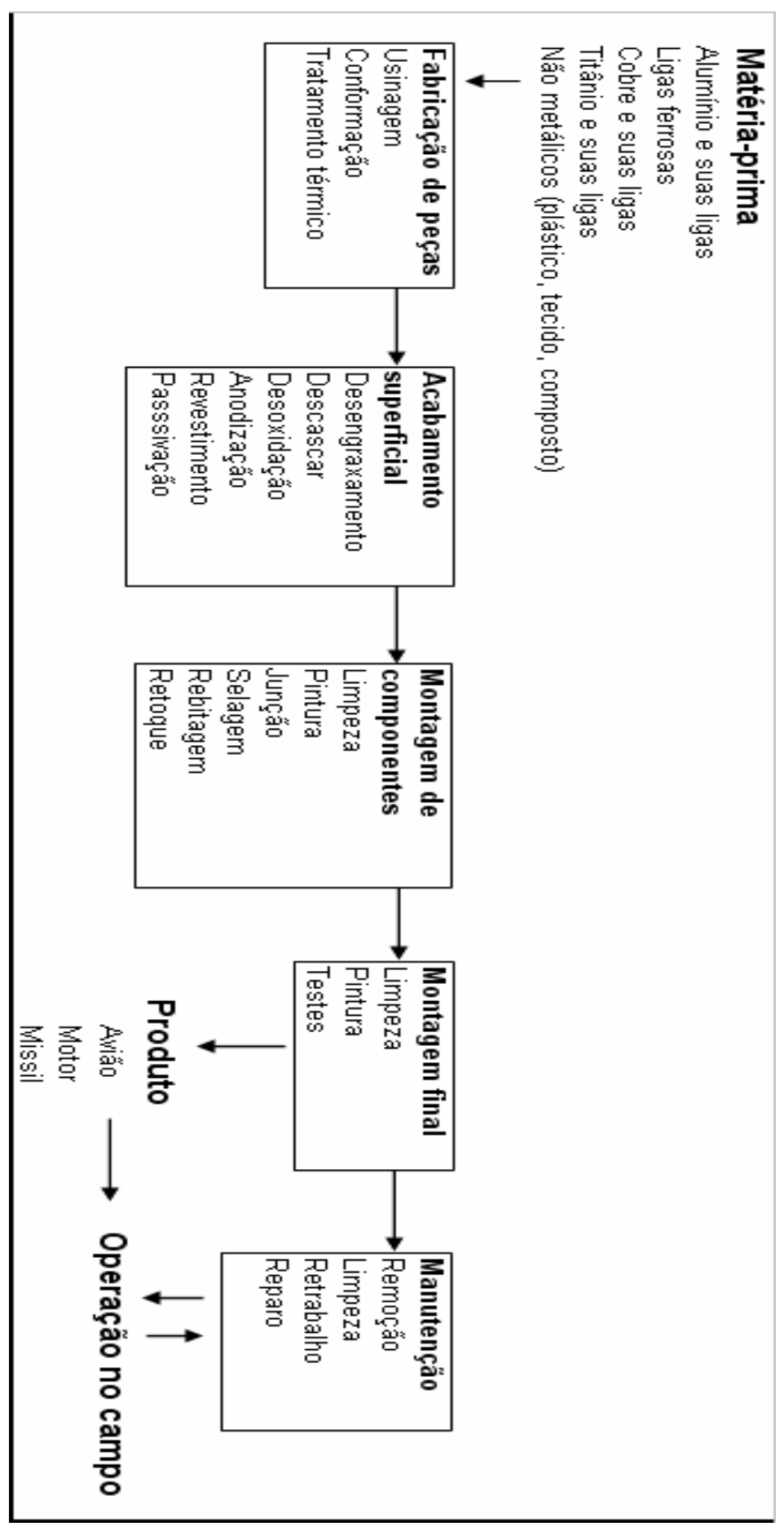

Fonte: $\mathrm{EPA}^{8}, 2006$.

${ }^{8}$ Environmental Protection Agency 


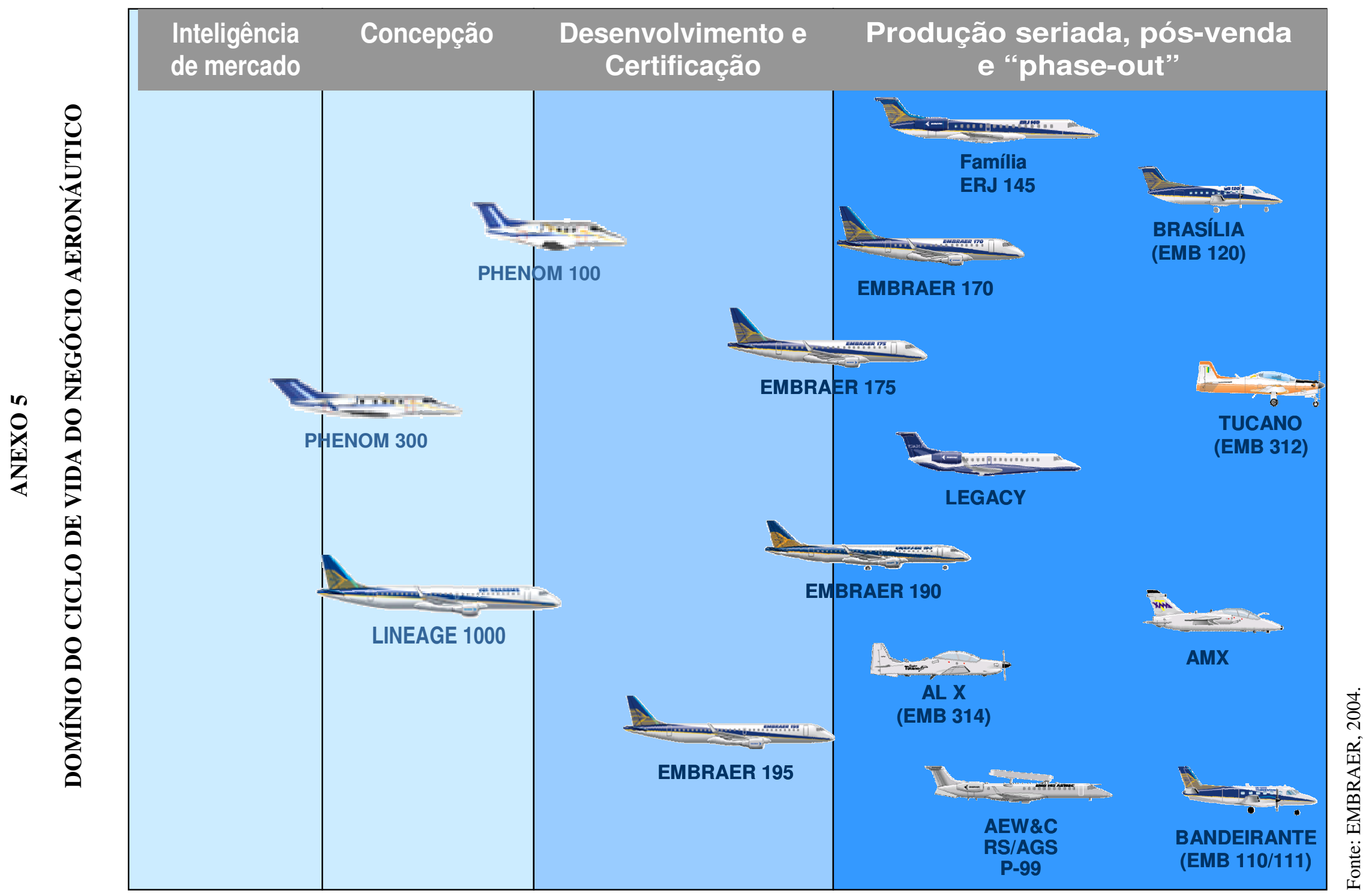

